UNIVERSIDAD NACIONAL DE LA PLATA

FACUlTAD DE HUMANIDADES Y CiENCIAS DE LA EDUCACIÓN SECRETARÍA DE Posgrado

\title{
Imágenes de la patria en el romancero cubano del siglo diecinueve
}

\author{
María Pía Bruno
}

Tesis para optar por el grado de Doctor en Letras

Directora: Gloria B. Chicote

Codirectora: Graciela N. Salto

La Plata, 6 de septiembre de 2014 


\section{Índice}

\section{Agradecimientos}

\section{Introducción}

1. Preliminares sobre el tema, la periodización y el corpus.......................... 6

2. Sobre la estructura de la tesis............................................ 13

Capítulo I. Los letrados en la configuración de la patria cubana.................... 16

1.1. Los letrados artífices de la patria........................................ 19

1.2. Sacarocracia, patria e identidad.......................................... 27

1.2.1. Dulces poderes en juego: el grupo reformista

ilustrado y la configuración de lo nacional.......................... 45

1.3. Poder blanco, cuerpos negros: retóricas del mestizaje

en el discurso patriótico....

1.4. La pluma que imagina la nación: hacia la invención de la patria.

1.5. La patria imaginada por Domingo del Monte.

Capítulo II. La sociabilidad literaria

2.1. La institucionalización de los espacios literarios:

academias, tertulias, publicaciones

2.1.1. En búsqueda de la autonomía cultural: de la Comisión Permanente

de Literatura a la Academia Cubana de Literatura.

2.1.2. Las tertulias delmontinas: una expresión de 
2.1.3. La crítica y la traducción como prácticas de lectura en las tertulias de Domingo del Monte.

2.2. Impresiones de la identidad: imprentas, publicaciones y lecturas

Capítulo III. La búsqueda del lenguaje patriótico

3.1. Cubanizar la lira: de la naturaleza al paisaje de la patria

3.2. Encrucijadas de la lengua, el estilo y la forma:

tensiones en torno al Romanticismo.

3.3. Figuraciones de autor: Domingo del Monte

y la construcción de la ejemplaridad

3.3.1. El autor maestro: el espacio letrado como ámbito discipular.....

3.3.2. Las máscaras del autor: ficcionalizaciones de la subjetividad.

3.4. El romance con la patria: el proyecto literario de Domingo del Monte.

3.4.1. Coda: el fracaso del romance o el éxito de la décima.

4.1. El romancero cubano y el romancero tradicional.

4.2.1. Naturaleza y paisaje: mediaciones de la mirada poética. 
Conclusiones

1. Primera parte

1.1. Consideraciones finales sobre la teoría................................ 279

1.2. Consideraciones finales sobre el corpus............................... 282

2. Segunda parte

2.1. Domingo del Monte y la invención de la patria "moderna".................. 286

2.2. Figuraciones sobre la patria: entre el olvido y la memoria.................. 291

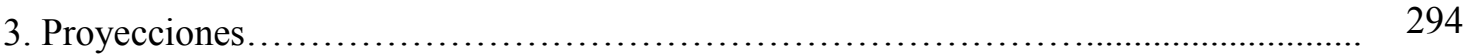

\section{Bibliografía citada}

1. Fuentes primarias....................................................... 300

2. Fuentes secundarias....................................................... 302 


\section{Agradecimientos}

No hubiese logrado tamaña aventura sin la colaboración, generosidad y afecto de algunas personas. Entre ellas, destaco, en primer lugar, a Graciela Salto, por estar desde antes del inicio, por no soltarme la mano en mis momentos de rebeldía, por confiar, por acompañar siempre su rigurosidad y excelencia académica con paciencia y cariño.

En segundo lugar, agradezco a Gloria Chicote, quien sin conocerme aceptó ser mi directora. En cada una de las etapas de la investigación me acompañó con aportes lúcidos y palabras cálidas que se transformaron en impulsos para continuar el trabajo.

Entre las personas que más me ayudaron están mis compañeros de las distintas cátedras de la Facultad de Ciencias Humanas de la Universidad Nacional de La Pampa: Marta Urtasun, Marisa Elizalde, Daniel Pellegrino, Sonia Bertón, Daniela Melchor. Agradezco infinitamente su generosidad, pues sin el apoyo concreto de ellos no hubiese tenido el tiempo suficiente para terminar las últimas páginas.

También agradezco a Diana Moro, Nancy Sad, Rosario Pascual y Carolina Domínguez. Todos ellas, en distintos momentos y de diferentes maneras, colaboraron con este proceso.

A mis amigas, Virginia González, Cecilia Gaiser y Silvia Spinelli, con quienes compartí este desafío enorme de iniciar — y terminar - un doctorado. Les agradezco la incondicionalidad y el sostén permanente y afectuoso que transformaron las largas horas de estudio compartidas en nuestra "casita del árbol" en una experiencia inolvidable.

A Jésica, Lucía, Diana y Luciana, amigas luminosas que toleraron con amor charlas eternas sobre el periplo de la tesis.

En el grupo de personas invaluables, hay dos que sostienen lo invisible y, a ellas, les dedico esta tesis:

Mamá, gracias por cuidar con tanto amor a Valentino, "para un príncipe enano se hace esta fiesta". Gracias por estar, incondicional, siempre.

Juan Pablo, amor, gracias por leer cada uno de mis borradores, por tu lucidez y tu coherencia. Por ser mi compañero y convencerme de que podía lograrlo. 


\section{Introducción}

\section{Preliminares sobre el tema, la periodización y el corpus}

En la primera mitad del siglo diecinueve, los letrados criollos representantes de la Ilustración cubana, alentados por un incipiente sentimiento patriótico proponen embrionarios proyectos culturales y políticos tendientes a pensar la identidad nacional en términos diferenciadores. Aunque Cuba logre la separación de la Corona española en 1898 , esta verdadera peripecia de la invención de la patria halla un momento de eclosión muy particular hacia 1830 cuando los intereses, muchas veces contradictorios, del sector criollo se canalicen en una multiplicidad de discursos (jurídicos, literarios, científicos, filosóficos y ensayísticos) que ponen en evidencia el surgimiento de una conciencia dispuesta a reclamar a la metrópoli peninsular el reconocimiento de la autonomía cultural y política de los cubanos ${ }^{1}$. Ese caudal discursivo, que es depositario de tensiones irresueltas, se ofrece como un corpus conveniente para indagar las representaciones que se configuran sobre la patria. Al mismo tiempo, esas textualidades delatan un escenario de polémicas respecto de ciertas construcciones de sentido generadoras de exégesis, tales como los pares "Tradición y Modernidad" o "Nacionalismo y Americanismo", entre otros. En la articulación de los imaginarios propuestos, los letrados cumplen un rol central al proponer y mediar en la recepción de tales configuraciones.

En este contexto debemos situar la figura de Domingo del Monte y reconocer en él "una propiedad irradiante" (García Marruz 2008) que lo ubica en el centro del ámbito letrado decimonónico. Nacido en Maracaibo, Venezuela, en 1804, hijo de dominicanos de familia patricia, emigra a Cuba a los seis años y adopta la isla como su patria. A los treinta años su nombre ya tiene peso propio, ocupa cargos culturales de

\footnotetext{
${ }^{1}$ Esta voluntad racionalizadora y diferenciadora debe comprenderse a la luz de los vertiginosos cambios políticos, culturales y sociales que atraviesa Hispanoamérica desde inicios del siglo diecinueve, cuando las gestas de emancipación llevadas a cabo en el continente ponen en evidencia los anhelos de autodeterminación y los esfuerzos por romper con la dependencia colonial. Los estudiosos reconocen la emergencia de una conciencia criolla muchos antes de que se inicie el periodo de emancipación, por lo general, marcado entre 1810-1830. Pues a partir de 1830 (el año de la muerte de Simón Bolívar) se produce la disolución de la Gran Colombia, creada en 1819 y símbolo de alguna manera del proyecto de integración política de las naciones liberadas y del espíritu americanista que tuvo el proceso emancipador, y se inicia una larga y conflictiva etapa de formación de las naciones.
} 
índole política y es apreciado por sus coetáneos por su incansable labor cultural. En este hombre de letras se cifran, en gran medida, los comportamientos, las tensiones y los anhelos que caracterizan a la intelligentzia criolla que brega por el progreso de Cuba. La modernidad latente en cada uno de sus ensayos y artículos genera, al mismo tiempo, un movimiento pendular en sus posiciones de enunciación. La oscilación actúa como síntoma de la modernidad (Grüner 2010) y caracteriza una de las paradójicas relaciones que se dan entre los letrados americanos y los centros de poder de la metrópoli (Rama 1984; Moraña 2004; Altamirano 2008).

Cierto es que la inquietud por la configuración de una identidad patriótica no es exclusiva de Domingo del Monte, sin embargo, la centralidad de su figura en el ámbito cultural de la primera mitad del siglo permite reconocer todo un entramado de relaciones letradas: instituciones, espacios de intercambio, publicaciones, etc. que hacen posible la enunciación de algunas hipótesis respecto del modus operandi de los letrados y su intervención consciente en la organización de los espacios de la sociabilidad literaria.

Entre los múltiples gestos culturales que impulsa Domingo del Monte, nos llama particularmente la atención la producción de un romancero de tema patriótico. En la vacancia de estudios sobre este repertorio convenimos la importancia de su abordaje, pues ha sido la narrativa anti-esclavista del período la producción más analizada por la crítica (Benítez Rojo 1988; Salvador Bueno 1988; Vera León 1991; Ramos 1996; Civantos 2005; Miller 2005; entre otros).

El vacío crítico sobre este romancero nos permite la formulación del problema $\mathrm{y}$, por otro lado, nos genera el desafío inaugural de su estudio. Al respecto, nos parece oportuno recuperar la reflexión que realizan Maximiano Trapero y Martha Esquenazi Pérez en el apartado sobre "Los romances cubanos del siglo XIX" en Romancero tradicional y general de Cuba (2002):

Lo que sí es del todo cierto con respecto a los romances cubanos del XIX es lo que dice Carolina Poncet: que el pueblo cubano 'los ignora completamente en la actualidad', valiendo esa 'actualidad' tanto para el comienzo del siglo veinte, cuando Poncet lo escribió como para el comienzo del siglo XXI cuando lo escribimos nosotros (33). 
Esta reactualización del desconocimiento nos conduce a pensar que - de alguna manera - nuestra investigación contribuye a la difusión de este corpus de romances pues pretendemos, a partir de una perspectiva crítica sociocultural, describir, por un lado, las características del ámbito letrado en el que se inscribe la producción de los romances cubanos y con ello establecer algunas relaciones entre los autores y el contexto histórico-cultural, tales como los vínculos de los escritores con el sector de la sacarocracia y las apropiaciones de las corrientes estéticas vigentes, como el Neoclasicismo y el Romanticismo. Por otro, analizaremos las imágenes de la patria que se elaboran en el romancero, es decir, exploraremos las figuraciones y las metáforas que, entendemos, articulan un ideario patriótico que se corresponde con una concepción racial y cultural que concibe una cubanidad "criolla y blanca".

Por último, pretendemos explicar en este contexto de reafirmación de la identidad criolla la elección del romance para la transmisión de valores y de idearios patrióticos. Al mismo tiempo, procuraremos esclarecer los vínculos con otras tradiciones literarias que se desarrollan a la par o en estrecha vinculación, como la décima y el romancero tradicional español.

$\mathrm{Al}$ respecto, Carolina Poncet y de Cárdenas (1879-1969), en un trabajo pionero sobre el romance en Cuba (1914) menciona la presencia, en paralelo al romancero tradicional, de un romancero culto, erudito, de tema patriótico "lánguido y pobre". Desde su mirada, muy vinculada con la matriz hispánica que divulgaba en esa época Ramón Menéndez Pidal, este corpus tiene un valor muy inferior, pues la mayoría de sus autores no pusieron en romance "sino lo más humilde de su ingenio, mientras que otros no pasaron de ser simples copleros". Este romancero es considerado por Poncet y de Cárdenas como un "producto artificial y de gabinete, resultado de una moda pasajera y que no tiene de popular más que los tipos (personajes) elegidos y el medio en el que se desenvuelven" (2002: 33). Al respecto, esta estudiosa explica el fracaso del romance porque el cubano ha optado por la décima, cuya musicalidad se asemeja más a su oralidad. Similar explicación ofrece Mirta Aguirre (1981) quien señala que lo valioso del romancero cubano del diecinueve es "la útil información de hábitos de vida, vestuario o descripciones de vivienda, y que apunta antes que cuaje la conciencia independentista, un orgullo y un amor por lo propio que figura entre los primeros 
indicios de lo que se podría denominar el 'separatismo espiritual' de los nacidos de la Isla" (25).

Sin dudas, la valoración más positiva sobre este repertorio la realiza Samuel Feijoo, el antologista de Romances cubanos del siglo XIX (1977), quien afirma:

El movimiento poético nacionalista de los romances cubanos es, en esencia y en voluntad, un movimiento de rebeldía contra la retórica general de España, la sanguinaria metrópolis. Es en sí una afirmación de la cubana deseosa de estar y ser actuar y crecer hacia una plenitud sin estorbos en la isla colonizada.

Los romances cubanos vinieron a destruir más que a separar la fea moda, absurda, importada de España, de los falsos romances moriscos, del XIX, de gola medieval, o romances con náyades suspirando bajo los mamoncillos o bien con indios aztecas y su plumerío colorado. Todo ello sería arrasado para poner en su lugar al paisaje cubano y a su habitante, el guajiro, sus costumbres (7).

Los pocos críticos que han realizado alguna mención sobre este romancero coinciden en destacar que es el primer movimiento literario consciente que se da en Cuba (Vitier 1957; Feijoo 1977; Esquenazzi 2002). Efectivamente, como hemos referido, hacia el tercer decenio del siglo diecinueve, emerge una conciencia de grupo que sitúa a la Ilustración criolla como articuladora de un imaginario simbólico que se proyecta en una tendencia literaria denominada "criollismo" y en un género particular, el romance. Por supuesto, dada la importancia de la décima en el desarrollo literario de Cuba, estimamos que en un estudio sobre el romancero deben considerarse, y problematizarse, las interrelaciones entre estos dos géneros, aspecto que trataremos en el capítulo III.

Con esta investigación pretendemos re-descubrir un corpus que - por diferentes motivos - la crítica no ha abordado y, con ello, tratar de explicar su emergencia a partir de considerar, por un lado, la proto-organización de un ámbito letrado que insinúa cierta autonomía y, por otro, sondear las postulaciones discursivas de los letrados sobre la identidad patriótica. En consecuencia, queremos indagar en este repertorio cómo se configuran distintas imágenes de la patria en función de un proyecto político y cultural que posiciona a los letrados criollos como protagonistas. En este sentido, proponemos como hipótesis inicial que los romances cubanos ponen 
de manifiesto la conciencia del sector criollo respecto de la necesidad de configurar un imaginario sobre la patria cubana que se proclame diferente de la metrópoli y, al mismo tiempo, homogeneizador de las diferencias. Asimismo, entendemos que la elección del romance como género tiene estrecha relación con el movimiento criollista o nativista que marca la tendencia literaria de la primera mitad del siglo diecinueve. Y que de alguna manera, el romance enlaza culturalmente a Cuba con España, es decir, posibilita en lo formal la enunciación de culturas "equiparables", y por tanto, promueve una posición autónoma. La elite criolla letrada sabedora del valor histórico del romance, de su vinculación con la esfera popular se apropia y usa este género (Chartier 1998; Ludmer 1988) para introducir determinados valores culturales y una particular visión de la historia que se articula en el criollo blanco (guajiro) como portador de la autoctonía y de los valores patrios. Este uso político del género a lo largo de la historia es señalado con pertinencia por Gloria Chicote, quien refiere:

Si a pesar de la diversidad formal y contenidística del género, continuamos buscando un denominador común, quizás este resida en la capacidad narrativa de los poemas. Mayoritariamente octosílabos con rima asonante en los versos pares, los romances dan cuenta de la construcción identitaria de cada comunidad que los transmite en cuanto a sus concepciones religiosas, sus definiciones políticas o sus estructuras sociales. Desde sus orígenes el género fue utilizado políticamente: visiones proárabes o procristianas son identificables en los romances sobre la guerra de la Reconquista, disputas sobre filiaciones se pueden detectar en los romances históricos referidos a la sucesión del trono de Castilla en el siglo XIV, y, en los siglos sucesivos, la producción romancística siguió dando noticia de los diversos acontecimientos del devenir histórico (Chicote 2012: XIX).

Si bien Samuel Feijoo reúne en su antología del romancero a veintiocho escritores cuyas obras se extienden desde la década del treinta a 1886, para esta investigación seleccionamos un corpus correspondiente a siete autores: Francisco Pobeda y Armenteros (1796-1844), Domingo del Monte (1804-1853) José Ramón Vélez Herrera (1808-1886), José Jacinto Milanés (1814-1863), Miguel Teurbe Tolón (1820-1857), Joaquín Lorenzo Luaces (1826-1867) y José Fornaris (1827-1867) cuya producción romancística se enmarca en el lapso de estudio estipulado: 1830-1868. La justificación 
del recorte temporal radica en que tomamos como fecha de inicio la irrupción de Domingo del Monte en el ámbito cultural de la isla, a partir de las diversas funciones que desarrolla en el Sociedad Económica Amigos del País y considerando la fecha de publicación de las Rimas americanas, 1833, antología en la cual se publican los cuatro romance del autor. Dado que nuestra intención es indagar en el romancero la configuración de una primera matriz simbólica, que exprese una cubanidad en ciernes, como fecha de corte proponemos 1868 , pues es el año en que se inicia la primera guerra en pos de la independencia cubana (1868-1878) conocida como la "Guerra Grande" o "Guerra de los Diez Años".

En cuanto a la construcción del corpus, para esta investigación seleccionamos un grupo de autores en cuya obra advertimos, de manera paradigmática, una serie de imágenes sobre la patria que consideramos operan como una plausible resolución al dilema que genera en el sector criollo la formulación de una identidad homogénea. En correspondencia con este criterio, el corpus de esta tesis está compuesto de la siguiente manera:

Domingo del Monte: "El montero de la sabana" (1833), "El desterrado del hato" (1833), "El guajiro" (1833), "La patria” (1833).

Francisco Pobeda y Armenteros: "Leyenda cubana” (1832), "Leyenda primera. Leonardo Fernández y Lutgarda Flores" (1831), "Leyenda segunda" (1832); "Leyenda tercera. Carlos Bravo y Luisa Aguirre" (1846); “Leyenda cuarta. María y Jesús Contreras" (1833); "Leyenda quinta. La vida del mayoral" (1855); "Leyenda sexta. Juan Pérez de la Rosa" (1833); "El día de la tormenta" (1855) y "Leyenda. La vida del Majagüero" (1855).

Ramón Vélez Herrera: "Elvira de Oquendo o los amores de una guajira" (1840), "La pelea de gallos" (1856), El combate de las piragüas" (1856). José Jacinto Milanés: “El negro alzado” (1835)

Miguel Teurbe Tolón: "El pollo de Juan Rivero" (1856), "Un rasgo de Juan Rivero" (1856).

Joaquín Lorenzo Luaces: "El tuerto de Guanajay” (1857). 
José Fornaris: "La flauta triste” (1855), "La madrugada en Cuba" (1868), "La tarde" (1867), "Las palmas" (s/f), "Managua" (s/f).

Pero además, sumamos a este corpus primario compuesto por romances, otras textualidades: cartas, artículos periodísticos, prólogos que nos permiten enriquecer la mirada sobre el romancero al comprender cómo se configura el ámbito letrado en el cual emerge esta producción singular. El análisis de estas textualidades, que conforma un corpus subsidiario nos posibilita diagramar el entramado cultural del periodo, establecer relaciones entre los letrados y caracterizar los espacios de sociabilidad y las prácticas de lectura que permiten la circulación y difusión de diversos textos.

En este sentido, el Centón epistolario de Domingo del Monte se aprecia como una voluminosa obra que reúne la correspondencia personal del autor. Tomamos como corpus de referencia el volumen II, que comprende la correspondencia entre 18361840. Entendemos que el discurso epistolar contribuye a la definición de los parámetros psicológicos y culturales dentro de los cuales se mueven los actores sociales del período $\mathrm{y}$, al igual que el discurso autobiográfico, produce un constructo de la imagen del yo como ajena al hablante, al escribiente. En consecuencia, las cartas definen un yo multifacético que se afirma también en una múltiple construcción de la alteridad. Es por ello que el análisis de las cartas permite reconstruir con regularidad y sentido cronológico una secuencia de hechos de valor significativo a nivel individual y comunitario. Por esa razón, como aprecia Mabel Moraña (1997) el texto epistolar tiene la finalidad primordial de verificar la existencia del otro y, como sabemos, "identidad y otredad (yo y tú, yo y el enemigo, yo y la patria, nosotros y ellos) son instancias inherentes a la invención de la nación, a la delimitación de sus fronteras reales e imaginarias, así como a la definición ideológica individual y partidaria” (94).

Asimismo, consideramos valiosos otros textos entre los que se destacan algunos informes que eleva a la Sociedad Económica Amigos del País como secretario de la Comisión Permanente de Literatura, de la sección de Educación de esa institución y artículos publicados en distintas revistas. Según este criterio, el corpus subsidiario está compuesto de la siguiente manera:

Del Monte, Domingo (1836-1840). Centón Epistolario. Vol. 2. 
. (1831-1836). “Informes y exposiciones pedagógicos” en Exposición de las tareas de la Comisión Permanente de Literatura de la Sociedad Económica Amigos del País. La Habana. . (1831). "Primeras poesías líricas de España" en Revista Bimestre. Num.1 mayo-junio. La Habana. . (1837). "El poeta”, El Aguinaldo Habanero, La Habana. . (1838). "La poesía en el siglo XIX”, El Álbum, La Habana.

Herrera Dávila, Ignacio (1833) Rimas americanas. La Habana.

\section{Sobre la estructura de la tesis}

El itinerario de lectura y análisis que proponemos se organiza en cuatro capítulos y una conclusión. La articulación de los capítulos se fundamenta en una lógica que podríamos suponer va de lo general a lo particular. En consecuencia, en una primera instancia indagamos en los aspectos contextuales (políticos-sociales y culturales) y establecemos las dimensiones teóricas que circunscriben el objeto de estudio. En una segunda instancia, reparamos en cuestiones más vinculadas con el espacio literario, tales como las nuevas prácticas de lectura, la circulación de los textos en el ámbito letrado y la problematización de las corrientes estéticas que sujetan la práctica escrituraria en el siglo diecinueve. Por último, nos centramos en el corpus de romances con una mirada atravesada por las instancias de reflexión previa. Entendemos que, de este modo, cuando arribamos al corpus, muchos de los aspectos medulares ya han sido transitados, sin embargo, el corpus literario revela otro espesor semántico, por lo tanto, no proponemos una aplicabilidad de teoría al corpus sino una puesta en diálogo que permita la problematización de ambos constructos.

A continuación, expondremos los lineamientos generales de cada capítulo, los cuales se corresponden con los objetivos propuestos y las hipótesis enunciadas.

En el capítulo I, "Los letrados en la configuración de la patria cubana" proponemos un acercamiento teórico a los tres ejes nucleares de la tesis: letrados, imaginarios y patria cubana. Presentamos el tema y reflexionamos respecto de su complejidad. Para tal fin, proponemos deslindar algunas categorías y nociones, tales 
como patria y nación, Americanismo y Criollismo. Cada una articula posiciones conflictivas en torno a los sujetos y a la representación colectiva que asumen. En segundo lugar, exponemos el lugar paradigmático de las élites criollas liberales, con la intención de desplegar las tensiones que modulan sus prácticas y gestos e inscribirlas en un contexto mediato de praxis política.

En el capítulo II, "La sociabilidad literaria” proponemos indagar en los espacios de circulación y sociabilidad de las letras cubanas que se gestan en la década de 1830 a 1840. El abordaje de estos ámbitos de promoción cultural tiene como objetivo caracterizar el medio letrado en el cual Domingo del Monte alienta el proyecto de un romancero cubano e instala entre sus contemporáneos el debate sobre las matrices simbólicas que buscan definir la identidad cubana. Para ello, repararemos en distintas iniciativas que visibilizan de qué modo se trazó en Cuba un proceso de configuración de lo nacional que puede analizarse a la luz de otras experiencias culturales y sociales generadas en el mismo periodo en el continente hispanoamericano. En este sentido, la réplica de estas experiencias pone en escena elementos comunes que permiten considerar la formulación de un trayecto ideológico ilustrado de sesgo americanista.

En el capítulo III, "La búsqueda del lenguaje patriótico" partimos de considerar que la función performativa, ética y pedagógica que se asigna al discurso político y ficcional del período se inicia con los primeros intentos por fundar una retórica verbal e iconográfica que exprese este incipiente deseo de autonomía. En este vértice, eclosiona la preocupación por la búsqueda de un lenguaje nacional. Nos preguntamos, entonces, ¿qué lengua y qué forma serían las más idóneas para expresar el ideario patriótico? Si en los capítulos anteriores señalamos la centralidad de la figura de Domingo Del Monte en la primera mitad de siglo, en este capítulo nos proponemos abordar, por un lado, su concepción de la lengua y la literatura, en relación al proyecto que alienta entre sus pares: la producción de un romancero cubano. Por otro, y en estrecha relación con la autofiguración de mentor de las letras cubanas, analizaremos las figuraciones de autor perfiladas en algunos de sus escritos.

En el capítulo IV, "Figuraciones de la patria en el romancero del siglo diecinueve" analizamos en un corpus de romances producidos por Domingo del Monte y algunos de sus contemporáneos, como Francisco Pobeda y Armenteros, Ramón 
Vélez Herrera, José Jacinto Milanés, Miguel Teurbe Tolón, Joaquín Lorenzo Luaces y José Fornaris cómo se configura el imaginario patriótico y, con ello, explorar qué representaciones se elaboran en este repertorio sobre los sujetos, el espacio, la cultura y la literatura. Nos interesa, por un lado, analizar las figuraciones y las tensiones en torno al imaginario desplegado y, por otro, poner de manifiesto las estrategias que permiten esa representación en correspondencia con las corrientes estéticas que las contienen.

Asimismo, en este capítulo planteamos las relaciones del romancero letrado con otras tradiciones, como la décima y el romance tradicional español.

Por último, en el apartado de las conclusiones proponemos la revisión crítica del itinerario propuesto, la reflexión sobre algunos núcleos problemáticos que condensan la tesis y señalamos ciertas proyecciones temáticas y genéricas del romancero decimonónico hacia el siglo veinte.

En síntesis, las páginas que a continuación se ofrecen son el resultado del asedio constante y consciente al corpus. Desde el inicio de esta investigación, su carácter ignoto nos ha interpelado como otra manera de aproximarnos al complejo panorama de las letras hispanoamericanas del siglo diecinueve. Entendemos que su estudio nos posibilita comprender las operaciones del discurso literario en tanto receptor y canalizador de las tensiones de un periodo tan particular como el que transita Cuba entre 1830 y 1868. En este sentido, la aproximación teórica y metodológica propuesta para el abordaje de este romancero insta al develamiento de un corpus que articula las diferentes posiciones políticas y culturales que asumen los criollos letrados y que se plasman en múltiples imágenes poéticas sobre la patria. 


\section{Capítulo I}

\section{Los letrados en la configuración de la patria cubana}

La pregunta por la identidad atraviesa América Latina desde el arribo de las primeras embarcaciones españolas ${ }^{2}$. Ese contacto primigenio, revelador y traumático produjo tanto afasias como hipérboles de la palabra. La configuración imaginaria de lo americano se ha construido desde entonces en el movimiento pendular de la carencia y la abundancia ${ }^{3}$.

Este mecanismo discursivo se hace particularmente visible en los procesos de emancipación llevados adelante a lo largo de todo el siglo diecinueve. El discurso de las élites culturales criollas que promovían la autonomía respecto de España condensa una serie de procedimientos retóricos tendientes a moldear el imaginario patriótico americano. Entonces, la indagación sobre la identidad ¿quiénes somos? se despliega

\footnotetext{
${ }^{2}$ Es sabido que la denominación del espacio americano se ha constituido en base a procesos identitarios muy complejos y que los sucesivos nombres que recibe el espacio comprendido desde el sur del río Grande hasta el estrecho de Magallanes responde a esta lógica nominativa. Es decir, según la etapa que estemos considerando y según los grupos interpelados deberemos consignar distintas denominaciones: Latinoamérica, Indoamérica, Iberoamérica, Panamérica, entro otros. "Cada nominación históricamente considerada lleva impresa una manera de definir y apropiarse de los contenidos y proyectos, que, en distintas épocas generaron respuestas y contrapropuestas" (Funes 2008: 16).

Para la apertura de este capítulo optamos por América Latina porque justamente intentamos poner en escena una pregunta cuya respuesta no ha cesado. Sabemos, no obstante, que en el periodo de corte de esta investigación, la denominación más apropiada sería Hispanoamérica o Iberoamérica (tal el uso que realiza François-Xavier Guerra en los múltiples trabajos tomados como referencia) porque designa un período colonial que en el caso de Cuba se continúa hasta 1898 (Haya de la Torre 1952). Por otra parte, la expresión "América Latina" es más moderna y está ligada a la república, pues se propaga en el contexto de la política expansionista del Segundo Imperio de Napoleón III, en la década de 1860. El panlatinismo supone una comunidad de orígenes anclados en la tradición cultural y lingüística del imperio Romano de Occidente y de la religión católica. La oposición entre la tradición sajona y latina se orienta a legitimar la ideología de expansión y dominio del panlatinismo. Como sostiene Patricia Funes, hacia la segunda mitad del siglo diecinueve "la pertenencia a lo latino esfuma, entonces, la herencia española y su tradición al mismo tiempo que ofrece una referencia ideológico-política en correspondencia con el modelo hegemónico de las oligarquías formadoras de los nacientes estados" (2008: 6).

3 Recuperamos para esta reflexión inicial los aportes de Julio Ortega en El discurso de la abundancia (1990) y de Edmundo O'Gorman (1958) en La invención de América. No obstante, los procesos de invención y de representación de la identidad americana nos son privativos del discurso dominante y colonizador sino que, tal como los entendemos, son el resultado un proceso marcado por la interacción conflictiva y traumática, razón por la cual la identidad heterogénea del sujeto americano es plasmada en una multiplicidad de discursos y prácticas semióticas que exponen una interpretación polifónica de la idea de invención de América. Ver Cornejo Polar 1991; Mignolo 1986; 1989; 2000; Lienhard 1992; Navarrete Linares 2012.
} 
bajo dos fórmulas interrogativas: ¿qué poseemos? ¿de qué carecemos? Al mismo tiempo, esta indagación lleva a enunciar una tercera instancia: "lo que no somos"

Quienes formulan estos interrogantes en el período decimonónico son los mismos que ensayan afanosas respuestas: los letrados. El rol que asumen en el periodo de conformación de los Estados nacionales es central pues articulan los deseos de la clase a la que pertenecen con intereses supraindividuales. Esta "labor de bisagra", definición acuñada por Carlos Altamirano, entre los centros que obraban como metrópolis culturales y las condiciones y tradiciones locales, posiciona a los idóneos de la cultura escrita y el arte de la argumentación como figuras ineludibles, sin las cuales se torna imposible pensar la historia política (Altamirano 2008: 9).

En este sentido, en este primer capítulo abordaremos las imaginarios letrados sobre la patria cubana que se configuran en el tercer decenio del siglo diecinueve, puestos en relación con el contexto latinoamericano y caribeño en el que se inscriben para poder analizar en los capítulos siguientes la función que cumplió el romancero en la articulación simbólica de estos constructos.

Ahora bien, para analizar el imaginario de la patria cubana consideramos necesario deslindar algunas categorías y nociones que intervienen en este complejo proceso de definición ${ }^{5}$. En primer lugar, el acercamiento que proponemos parte de

\footnotetext{
${ }^{4}$ El concepto de identidad es sumamente complejo y arrastra abundantes interpretaciones según los paradigmas que encuadren su reflexión. Seguimos en este trabajo los aportes sobre el concepto que elabora Cécile Leclercq (2004), quien refiere que es un concepto ambiguo, ambivalente y multidisciplinario. En palabras de Claude Levi Strauss un "concepto encrucijada", pues es utilizado en las Ciencias Humanas como un concepto global que asume diferentes acepciones. Se caracteriza, en este sentido, por su fluidez y polisemia. Leclercq postula que la complejidad del concepto requiere que se lo analice como: 1) "concepto moderno", devenido de la Psicología Social (EE.UU), en los años 50 del siglo veinte para abordar los problemas de los inmigrantes; 2)"concepto duplo", pues toda identidad se determina refiriéndose a otra. Identidad y alteridad están relacionadas dialécticamente; 3 ) "concepto dinámico", porque originalmente es una noción proveniente de la lógica filosófica (relación que cada individuo tiene consigo mismo) y luego ha pasado a la Psicología Social y a otras Ciencias Sociales. En este sentido dinámico es primeramente una acepción que refiere a la identidad del individuo, la cual no es fija, sino que evoluciona, se forma progresivamente, se reorganiza y se modifica sin cesar.

Si bien identidad y cultura son conceptos estrechamente ligados, no deben confundirse pues la cultura puede funcionar sin conciencia de identidad cuando las estrategias de identidad pueden manipular y aún modificar una cultura (2004: 99).
}

5 Aunque se reconozcan diversas definiciones, la noción de "imaginario social" la postula en 1975 Cornelius Castoriadis, con ella alude a la configuración de significaciones históricas que permite que los sujetos pertenecientes a una sociedad identifiquen su propio mundo del mundo de los otros, otorgándole una capacidad de alteridad, que los distingue y les permite autoreferenciarse. Castoriadis concibe esta noción como una producción ontológica de un modo particular de ser que instituye la corporización de 
considerar las concepciones de patria y nación, distinguirlas en su uso y pertinencia. En relación a éstas, emergen otras categorías, tales como criollidad, cubanidad y americanismo. Cada una articula posiciones conflictivas en torno a los sujetos y a la representación colectiva que asumen. En segundo lugar, y como ya señalamos al inicio de este capítulo, expondremos el lugar paradigmático de las élites criollas liberales, con la intención de desplegar las tensiones que modulan sus prácticas y gestos e inscribirlas en un contexto mediato de praxis política.

En relación a la ecuación identidad patriótica / letrados / contexto, emergen una serie de nociones que atraviesan la retórica y anclan el discurso históricamente. Algunas de estas concepciones provienen de los paradigmas que gozan de estatus durante la primera mitad del siglo diecinueve y que se convierten en marcos de interpretación de los problemas del hombre. Tal es el caso del Positivismo y las ideas sobre la raza, la influencia del ambiente, la evolución, el progreso. En otros casos, la retórica que impregna los discursos epocales deviene de las corrientes estéticas vigentes, como el Neoclasicismo y el Romanticismo con las implicancias sobre los géneros y sus usos que esto conlleva.

Como entendemos que las categorías que son funcionales para analizar el contexto de emergencia de las configuraciones de la patria cubana no pueden abordarse en forma aislada sino en el marco específico bajo el cual se problematizan, este primer capítulo se estructura en la relación permanente entre dos instancias. Por un lado, la descripción de los grupos letrados que organizan la esfera simbólica de la representación patriótica. Es decir, la identificación de las élites letradas, la delineación de sus intereses y las formas que eligen para plasmar este ideario. Por otro, la

un "magma de significaciones imaginarias sociales" que regula los discursos, las prácticas, los deseos y los sentires de un conjunto identitario de sujetos. En este sentido, la interpretación que una sociedad crea para sí constituye su identidad. En este trabajo seguimos la noción de "imaginario" que postula Edouard Glissant (1997) quien concibe el imaginario como una construcción simbólica mediante la cual una comunidad (nacional, racial, imperial, sexual, etc) se define a sí misma. Como observa Walter Mignolo (2003) en Glissant el término no tiene ni la acepción común de una imagen mental ni tampoco el sentido más técnico que tiene en el discurso analítico contemporáneo, en el cual el Imaginario forma una estructura de diferenciación con lo Simbólico y lo Real. 
explicitación de las categorías que — consideramos - son convenientes para analizar las configuraciones letradas del imaginario patriótico.

\subsection{Los letrados artífices de la patria}

En el desarrollo histórico de Cuba es posible advertir diferentes momentos de transición en los cuales se definen y proyectan imágenes que vinculan la identidad nacional con distintos elementos de significación: geográficos, históricos, étnicos y culturales. Estos elementos demarcadores se implican, superponen y alternan configurando matrices simbólicas diversas a partir de las cuales se elabora una idea de identidad colectiva ${ }^{6}$. En función del modo en que se articulan dichos elementos, esta síntesis sufre desplazamientos y reelaboraciones.

Es decir, los discursos sobre la identidad nacional cubana, esto es, la "cubanidad" responden a las relaciones entre poder y cultura. De ahí que no existe, como sostiene Cécile Leclercq (2004) una "cubanidad auténtica y esencial" sino una pluralidad de identidades cubanas construidas por diferentes grupos sociales en diversos momentos históricos. En el periodo que nos ocupa, fueron los criollos quienes destacaron su diferencia con la metrópoli primero mediante la representación de su geografía, después de su historia y finalmente de su sociedad. En este sentido, hay tres identidades que se superponen y remiten unas a otras:1) identidad territorial; 2) identidad histórica y 3) la formación de una identidad social.

Una primera condensación de imágenes liga la identidad colectiva a un sentimiento de pertenencia a un terruño. En consecuencia, la peculiaridad de la naturaleza cubana actúa como elemento demarcador que permite establecer una

\footnotetext{
${ }^{6}$ Si bien el concepto de "identidad colectiva" es reciente en las Ciencias Sociales pues aparece en 1968 con el brote de movimientos sociales que apelan a una identidad de grupo o a una categoría social para contestar a una relación de dominación y reivindicar la autonomía, lo cierto es que la problemática de la identidad colectiva no es nueva, pues siempre surge cuando un grupo entra en contacto con otro(s) grupo(s) y los respectivos sistemas culturales, los respectivos intereses económicos o políticos se enfrentan. Como sostiene Leclercq "el concepto de identidad colectiva designa lo que hace la unidad de un grupo (o de una nación), su diferencia con relación a otros grupos (a otras naciones), un conjunto singular de características propias que significa y simboliza esta unidad y esta diferencia, e igualmente la permanencia de este grupo en el tiempo, a través de la historia, a pesar de todos los cambios que lo afectaron (Lecqlerc 2004: 102).
} 
diferencia con el Otro, al mismo tiempo que un reconocimiento de la propia singularidad.

En un segundo momento, es la condición histórica y económica que imprime el colonialismo el factor que favorece la percepción de que Cuba sea pensada como distinta de la metrópoli española.

Con respecto a la configuración socio-cultural de una comunidad converge tanto la relación que los sujetos expresan con la tierra en donde han nacido y habitan como las condiciones materiales de producción que afectan el sistema y la organización social. En consecuencia, lo cultural, como tercer elemento de demarcación, se alimenta de las imágenes que la sociedad edifica de sí misma. En un sentido tradicional, lo cultural se articula con todo aquello que se designa y refiere con la expresión "costumbres de un pueblo o comunidad", es decir, con una determinada forma de vida, con hábitos de consumo y prácticas religiosas que se identifican con cierta moral. Cuando la identidad colectiva busca asentarse en el elemento cultural surge como necesidad la revisión de los aspectos sociales y étnicos que constituyen la trama social. Si se advierten elementos díscolos que entran en tensión y contradicción se presenta, entonces, como un requerimiento de construcción identitaria, la necesidad de homogeneizarlos. Razón por la cual, el proceso de elaboración de una identidad colectiva se define por una dinámica de inclusión y de exclusión, con el objeto de exponer u omitir determinados elementos culturales.

En este complejo proceso de elaboración intervienen conscientemente los letrados que, en tanto agentes culturales, desde perspectivas e intereses heterogéneos instalan, promueven y difunden una determinada concepción de identidad. La conflictiva relación entre los letrados y los órganos representantes del poder político y económico pone en evidencia la permanente tensión trasladada a continuas negociaciones y reformulaciones sobre la idea de patria.

Resulta funcional para pensar este lugar paradigmático del letrado recuperar la noción del "letrado patriótico". Jorge Myers (2008) explora esta figura y explica que surge entre las décadas de 1780 — cuando la independencia norteamericana, primero, y la Revolución francesa, luego, conmovieron los cimientos del Antiguo Régimen europeo y transatlántica- y la de 1820, cuando el derrumbe definitivo de esa 
monarquía en América modificó el entorno institucional y político en cuyo interior estos letrados debían actuar. Formados en el seno de la monarquía experimentaron una transformación profunda en su situación y atributos. Como observa Myers,

obligados a pronunciarse acerca del futuro rumbo de sus respectivas patrias, como consecuencia de la profunda crisis generada por la invasión napoleónica y la doble revolución — la de los constitucionalistas de Cádiz y la de las insurgencias autonomistas y republicanas en suelo americano- los letrados se vieron arrojados a una situación inédita que los obligó a asumir la compleja tarea de actuar con cierta autonomía (relativa y sujeta a distintas intervenciones represivas) frente a los poderes públicos y a convertirse en artífices de las nuevas identidades (2008: 121).

El proceso general que describe Myers respecto de esta transformación abarca tres etapas. La primera, la de los letrados defensores de las cualidades positivas de los americanos frente a la crítica o el desprecio peninsular. La segunda o de los llamados "precursores", quienes en el contexto ambivalente y de incierto porvenir que se abrió con el comienzo de la crisis del Antiguo Régimen defendieron la igualdad de los derechos de los súbditos hispanoamericanos del rey frente a los de sus súbditos peninsulares. En muchos casos, estos mismos letrados se convirtieron luego en voceros de una posible renegociación del pacto de dominación colonial y, la tercera que corresponde a la de los letrados del nuevo régimen cuyo estatus en relación con los nuevos poderes se habría modificado al obtener mayor autonomía ${ }^{7}$.

Como veremos en el desarrollo de estas páginas, los letrados en los que haremos foco se inscriben tanto en el primero como en el segundo grupo puesto que detentan la defensa de los derechos criollos, reclaman autonomía pero, al mismo tiempo, mantienen relaciones ambivalentes y contradictorias con la metrópoli.

\footnotetext{
${ }^{7}$ Por supuesto, como advierte Myers no todos los letrados de la Ilustración fueron "letrados patriotas". En "El letrado patriota: los hombres de letras hispanoamericanos en la encrucijada del colapso del imperio español en América" el autor esgrime las razones por las cuales incluye y excluye del listado de letrados patriotas a algunos personajes de la historia latinoamericana. En síntesis, las palabras de Myers deben resonar como una advertencia para no caer en el error de encuadrar, de manera forzada, bajo esta categoría a escritores cuya obra y pensamiento no se corresponden con la figura en cuestión. Ver Carlos Altamirano (director) y Jorge Myers (editor del volumen) 2008: 122-143.
} 
Para Myers fue significativo que el cambiante contexto político y socio-cultural con sus amenazas, sus presiones y sus oportunidades haya determinado su transformación en patriotas y no el marco ideológico específico con el que ellos pudieron haberse identificado de antemano.

Es decir, cada uno de estos hombres de letras debió definir su ideología en un contexto sociopolítico variante y vertiginoso. En consecuencia, sus producciones estuvieron marcadas por virajes ideológico-políticos en función de su relación concreta —en términos de su posicionamiento en el interior de un campo de fuerzas en pugnacon la cambiante realidad política y en función también de la interpretación que hacían de ésta.

No en vano, Myers considera que estos letrados se encuentran en una encrucijada ocasionada por el colapso del imperio español en América.

Hay tres aspectos que los definen: primero la voluntad de convertirse en representantes de la patria a la que pertenecen; segundo, se arrogan el derecho de representar por escrito a la patria y tercero, asumen la tarea de definir cuál es la naturaleza de esa patria. Estas características ponen de manifiesto la emergencia de una clase letrada, de índole criolla y liberal que es consciente como nunca antes del valor de la palabra. En consecuencia, elaboran un discurso que opera simbólicamente sobre lo concreto. O dicho de otra manera, los letrados se convierten en artífices de la patria, en edificadores de la identidad.

Según Myers

Durante un periodo relativamente acotado, el capital simbólico de los especialistas en el empleo del discurso escrito se convirtió —en algunas regiones al menos, y con variaciones significativas de un momento a otro en cada región - en un capital político real, al menos en el plano de la lucha por definir los contornos del nuevo orden que tan trabajosamente comenzaba a emerger (2008: 142).

Los aportes de Carlos Altamirano nos permiten pensar en el espesor semántico que condensa la noción de intelectual. El sociólogo ensaya una definición que reúne una serie de elementos descriptivos que son funcionales para comprender la complejidad de esta categoría: 
Los intelectuales son personas, por lo general conectadas entre sí en instituciones, círculos, revistas, movimientos, que tienen su arena en el campo de la cultura. Como otras élites culturales, su ocupación distintiva es producir y transmitir mensajes relativos a lo verdadero (a lo que ellos creen verdadero), se trate de los valores centrales de la sociedad o del significado de su historia, de la legitimidad o la injusticia del orden político, del mundo natural o de la realidad trascendente, del sentido o del absurdo de la existencia. A diferencia de las élites culturales del pasado, sean magos, sacerdotes o escribas, la acción de los intelectuales se asocia con lo que Régis Dèbray llama grafoesfera —es decir, con el dominio que tiene su principio en la existencia de la imprenta, los libros, la prensa-. Los intelectuales se dirigen unos a otros, a veces en forma de debate pero el destinatario no es siempre endógeno: también suelen buscar que sus enunciados resuenen más allá de la vida intelectual, en la arena política.

En América Latina y hasta avanzado el siglo XIX esa esfera de la cultura intelectual estuvo bajo el poder de los varones, fueran descendientes de familias de fortuna, herederos de un capital cultural o autodidactas. Las mujeres no participarían en ella sino marginalmente. En esta visión el intelectual no es una figura eterna que atraviesa las épocas y las culturas, es una especie moderna (2008: 15).

Transcribimos el fragmento anterior pues condensa características que desarrollaremos en el devenir de este trabajo. Al respecto, en el capítulo II se analizan los espacios de socialización letrada, y se recupera con ello la idea del intelectual conectado con otros intelectuales. Al mismo tiempo, en ese mismo capítulo se exploran los dominios de la letra escrita: la prensa, los libros y la correspondencia.

El conjunto de esta investigación parte de plantear a los letrados decimonónicos cubanos como sujetos modernos, con conciencia plena de su labor y con la certeza de que tienen una misión que cumplir, formadora y educadora del pueblo. Los debates y las polémicas puestas en escena tienen como objetivo mostrar que la esfera de los letrados no está exenta de tensiones y contradicciones.

En este sentido, el periodo tomado como corte para este trabajo hace visible precisamente - el campo de lucha entre facciones letradas que devienen de distintos sectores políticos y clases sociales. Y como bien advierte Myers, será el advenimiento 
de un "sentir patriótico" la condición que restaure la figura del letrado, otorgándole un sentido existencial en un contexto quebrado institucionalmente.

Si reparamos en la idea de intelectual como "especie moderna", se comprenden con mayor claridad las concepciones que identifican al hombre de letras como un apóstol secular, educador del pueblo y ejemplo digno de imitación. Estas características prototípicas (extendidas hasta mediados del siglo veinte) se forjaron en la cultura de la Ilustración que les proporcionó a los letrados una imagen de su papel social.

El discurso americanista se entretejió tempranamente con esa representación de los hombres de saber, tanto que "el panteón de hombres elevados se configuró con los héroes de la emancipación y con los héroes del pensamiento" (Altamirano 2008: 16). Desde esta perspectiva, entendemos el Americanismo como la empresa intelectual de estudio y erudición destinada a indagar, valorizar y promover la originalidad de América Latina ${ }^{8}$. En el marco de este pensamiento se cristaliza la representación del hombre de letras como apóstol y visionario, que honra a su país con sus obras y lo inspira con su pensamiento y su acción cívica. Esta representación se nutre, en consecuencia, de las imágenes de maestro, mentor y guía para explicar el rol cívico de los letrados, quienes articulan en un discurso edificante la patria americana. Si bien explicitan las peculiaridades y diferencias, al mismo tiempo, convergen en elementos comunes (históricos, culturales, lingüísticos, religiosos, institucionales, entre otros) que otorgan una identidad nacional continental ${ }^{9}$.

\footnotetext{
${ }^{8}$ Alocución a la poesía, de Andrés Bello, publicada en Londres en 1823 suele ser considerada por la crítica como la piedra fundacional del americanismo. Intelectuales del siglo diecinueve como José María Torres Caicedo (Colombia), Juan María Gutiérrez (Argentina) y José Enrique Rodó (Uruguay) configuran un primer americanismo que luego se continuará en el siglo veinte con personalidades como Pedro Henríquez Ureña, Mariano Picón Salas y Alfonso Reyes. El principio rector del americanismo fue la denominada "utopía de América", entendida como la búsqueda en el pasado de valores a rescatar del olvido y de elementos que anunciaban su independencia intelectual o preparaban lo que debía ser su originalidad moderna. El agente por excelencia de esa obra era en palabras de Rodó la "inteligencia americana", es decir, el cuerpo ideal de las minorías ilustrada, investidas de la misión de ofrecer luz y guía en un continente vasto, tumultuoso e inhospitalario para el espíritu. Estas elites debían operar la síntesis entre la cultura europea y la realidad natural y cultural de América. Ver Ardao 1970; Ramos 1989; Dávila 2005; Crespo 2008; Lempérière 2008.

${ }^{9}$ Luis Tejada Ripalda (2004) se pregunta qué es el americanismo y en el desarrollo teórico que despliega en torno a ese interrogante deja en claro que, si bien hay muchos textos que podrían clasificarse como americanistas, son muy pocos los estudios críticos que analizan tal fenómeno. El autor ubica al argentino Alfredo Palacios como uno de los primeros pensadores en reflexionar sobre este tema en una
} 
Para Dávila (2005), el Americanismo se ha distinguido por la necesidad de proponer nuevas lógicas y nuevas significaciones a la expresión del hombre americano que permitan, de alguna manera, resolver los dilemas de su entidad cultural frente a la cultura europea. La preparación de la Modernidad en América Latina se formula de dos maneras: primero, el sujeto americano expresa un apego creciente a la naturaleza y a la realidad social de ese Nuevo Mundo, cada quien fundamentando su propia localidad y sentido de lo nacional. Segundo, como el inicio de un amplio sentimiento continental de pertenencia e identificación, de defensa de este hombre americano, y al mismo tiempo de independencia y diferenciación con las metrópolis.

Dávila considera que las primeras manifestaciones del Americanismo, tenues e indirectas, se pueden rastrear en los últimos cincuenta años del siglo dieciocho. Los escritores de este periodo, advierte Dávila, produjeron para expresar y fundamentar su naciente conciencia americana una abundante literatura descriptiva y crítica inspirada en América, en la que se funden una sutil propaganda contra el español y la curiosidad científica que la razón comenzaba a exhibir en la época. Para Briceño Guerrero (2007), los dos discursos que nutren el pensamiento americano son el "cristiano hispánico" o “discurso de la Europa primera", que se afirmó en lo espiritual, por los valores divinos de la religión cristiana, y en lo material, por el sistema de jerarquías engendrado en la vida colonial; y el discurso denominado "europeo segundo" — discurso por excelencia de la Modernidad - estimulado por el auge teórico de la filosofía de la Ilustración, del pensamiento racional y de la ciencia moderna.

El Americanismo se comprende desde esta perspectiva en relación con el anuncio de la Modernidad. Y si bien el periodo independentista de América Latina que se inaugura en 1810 posibilitó el pensamiento diferenciado con respecto a España, no se puede negar la existencia de una herencia colonial que fue de primera importancia para la formación de un "espíritu americano". Por esa razón, es posible hablar de una “identidad colonial americana" que se constituye en torno a cinco puntos: 1) el sentido

conferencia dada en la Universidad de Buenos Aires en 1923, en la cual expone su postura antiimperialista yanqui bajo la fórmula "esa emoción americana que es como un patriotismo agrandado". La recuperación del discurso de Palacios como punto de partida del análisis que propone Tejada Ripalda permite, además, entender la emergencia de una noción de identidad colectiva americana, respetuosa de las soberanías nacionales. En este sentido opera la idea de Palacios respecto de ampliar la patria para tener una ciudadanía continental. 
de lugar, 2) identificación de objetivos, 3) insistencia en patrones, 4) sentido de historia, 5) pérdida de identificación con el Imperio (Dávila 2005: 9). Estos elementos se tornan visibles en el camino hacia la autonomía cultural, objetivo anhelado por los letrados de la Ilustración, pues serán quienes tracen y perfilen una nueva conciencia histórica, generadora de articulaciones entre la política y la cultura.

El Americanismo tal como lo entendemos es funcional, entonces, para pensar las posturas de los letrados decimonónicos y, sobre todo, para considerar las autorepresentaciones puestas en juego.

El carácter apostólico de los hombres de letras como salvadores de la humanidad hizo que el Americanismo fundara un panteón de intelectuales. Sin embargo, esta representación no basta para definir la singularidad de los letrados y su condición debe problematizarse en relación con las posiciones de poder. Las reflexiones plasmadas por Ángel Rama en La ciudad letrada (1984) pueden ser un punto de partida para esclarecer el lugar de poder que tiene el letrado desde la ciudad colonial hasta el modernismo. Rama afirma que la función de las élites culturales dentro del sistema de poder era la de producir discursos de legitimación del orden social, incluida la definición de la cultura legítima, que no era otra que la de los mismos letrados. La razón de la dilatada conservación de su preeminencia residió en que durante siglos las minorías letradas retuvieron el monopolio de la escritura en una sociedad analfabeta. Ni las revoluciones de la independencia ni la construcción de los estados nacionales modificaron el valor del capital cultural asignado a la letra.

Sin embargo, la crítica ha revisado los valiosos aportes que Ángel Rama ha realizado al campo de los estudios latinoamericanos y hay consenso en señalar que la tesitura del crítico uruguayo cae en una óptica culturalista que le otorga a su enfoque un grado de homogeneidad y autonomización de la praxis cultural que no guarda correlato con la movilidad que la práctica escrituraria ha tenido desde la Colonia hasta el Modernismo. Al mismo tiempo, en su análisis quedan fuera los aspectos dialógicos entre las diversas modalidades culturales (centrales y marginales) y los estratos sociales que componen la totalidad americana. Como sostiene con lucidez Mabel Moraña: 
Creo que el problema fundamental estriba en la ambigüedad y continuidad histórica sobre la que se basa el concepto de letrado en torno al cual se organiza el libro de Rama. Esta designación que, en puridad, parece aplicarse más bien al período colonial, adquiere una modulación diversa en la primera etapa de dominación imperial y dentro de la sociedad criolla, en el contexto de la cultura barroca virreinal, cuando la emergente conciencia criolla impone un tono impugnador y reivindicativo a la utilización de los discursos metropolitanos (1997: 169).

En consecuencia, es necesario reconocer sobre el fondo de esta prolongada continuidad que liga a la gente de saber con la estructura de dominación social los cambios en las modalidades del papel social asignado a los letrados y los discursos correspondientes de legitimación. Asimismo, las élites letradas no deben ser consideradas como simples mandatarias de otros poderes pues la verdadera fortaleza de estas élites culturales reside en su función de productores de mensajes, y sobre todo, en su especificidad como diseñadores de modelos culturales destinados a la conformación de ideologías públicas.

En síntesis, los letrados patriotas entroncan en su accionar dos funciones: la de constructores del imaginario patriótico y la de asumir el rol cívico de guías de la patria. Con esta doble intervención, el letrado legitima tanto su lugar social como su obra ${ }^{10}$. En este sentido, los letrados despliegan una serie de mecanismos de legitimación que se corresponden con procesos de autofiguración que especularmente le devuelven la imagen del papel social que representan.

\subsection{Sacarocracia, patria e identidad}

Recién en las postrimerías del siglo diecinueve, tras concluir la denominada "Guerra de la Independencia" (1895-1898) Cuba deja de ser posesión ultramarina española. A pesar de ser una de las últimas colonias en lograr la independencia, podemos reconocer

\footnotetext{
${ }^{10}$ Sirve para pensar el lugar privilegiado de los letrados en el campo cultural la aproximación teórica que realiza Pierre Bourdieu (1988) quien aplica la noción de "distinción o diferenciación social" para explicar la asignación de tipo simbólica determinada por el capital cultural (no económico).
} 
a lo largo del siglo diecinueve singulares procesos de invención y reinvención de la cubanidad, en los cuales la identidad se desliza del Criollismo blanco hacia la utopía mestiza y mulata.

Advertimos que - hacia 1830 - se gesta un primer imaginario de la patria cubana. En este período son numerosas las marcas que ponen en evidencia un lento pero continuo proceso de diferenciación y delimitación identitaria. En este sentido, obras referidas a la geografía, la historia, la lengua y la cultura exponen una novedosa necesidad de diferenciación y peculiaridad que va de la mano con el deseo de que Cuba ingrese de lleno en la Modernidad. Este anhelo impulsado por la Ilustración cubana se plasma en una serie de publicaciones y gestos culturales de índole muy diversa. Se podría citar como puntapié la publicación en 1830 de la obra de José M. F. de Arrate, escrita en 1761, Llave del Nuevo Mundo. Antemural de las Indias Occidentales. La Habana descrita. Noticia de su fundación, aumentos y estados.

Asimismo en esta década se crean numerosas instituciones que regulan el estudio y la divulgación de la historia, y al mismo tiempo, enmarcan la labor de los letrados. Se destacan la Comisión de Historia de la Sociedad Económica de los Amigos del País (1830) y la Academia Cubana de Literatura (1834). Además, la prensa posibilita la difusión del ideario patriótico de la Ilustración. Aparecen en escena la Revista Bimestre (1831-1834), el Plantel (1838-1839) y El Aguinaldo Habanero (1838), entre otros. Respecto de la articulación entre letrados y prensa y sobre el impacto que estas publicaciones tuvieron en la difusión y condensación de las matrices simbólicas de la Ilustración cubana nos referiremos con extensión en el capítulo II.

También en el plano lingüístico-cultural los letrados bregarán por el reconocimiento de una lengua particular. Esta intención se materializa con la publicación en 1836 del Diccionario provincial de vozes cubanas de Esteban Tranquilino Pichardo y Tapia (1799-1879).

Además, en el mismo período se publican en Cuba los resultados de las investigaciones que resultan de los viajes exploratorios que realiza Alexander von Humboldt por la isla durante 1805. Estas investigaciones se reúnen primero en el Ensayo político sobre la isla de Cuba de 1826, y luego, en 1831, con la publicación de 
Cuadro estadístico de la Isla de Cuba para los años 1825-1829. Con ambas obras se difunden las particularidades geográficas que distinguen a la isla caribeña.

Las publicaciones y las acciones culturales mencionadas expresan el deseo consciente de la Ilustración criolla cubana de lograr una autonomía, al menos, en un principio, en el plano cultural. En este contexto, emergen una serie de discursos de índole literaria, "científica", periodística y ensayística que reclaman la construcción identitaria de Cuba con el propósito de edificar la patria cubana. Son textos producidos por un grupo de letrados criollos, vinculados con la sacarocracia que, alentados en un primer momento por las lecturas de diversos textos filosóficos de la Ilustración europea y del Romanticismo, y luego influidos por las nuevas teorías positivistas elaboran un determinado proyecto de nación, constituido en el sentir patriótico, que como hemos explicado a partir de la definición de "letrado patriota" es un sentimiento devenido de la compleja coyuntura social y política. En este contexto, Domingo del Monte alienta la escritura de un romancero cubano que articule simbólicamente el ideario patriótico. Como afirma Lisandro Otero, la ruina de Haití, luego de la revolución genera un incremento muy importante en el valor del azúcar, en consecuencia, se produce lo que Moreno Fraginals denomina "el despertar grandioso de la consciencia burguesa cubana" (Otero 1990: 723). El auge vertiginoso del mercado se produce entre las décadas de 1790 y 1834 debido a la introducción de procedimientos tecnológicos en la producción azucarera. La sacarocracia es definida, entonces, como la nueva clase burguesa que se enriquece rápidamente gracias a la posesión de plantaciones e ingenios. Una burguesía que adquiere conciencia de su peso social, de su responsabilidad histórica y traza un proyecto de nación por el que se va a trabajar más de medio siglo. El principal promotor de este proceso es José Antonio Saco (17971879). Para él y para quienes lo acompañan ideológicamente, como Domingo del Monte (1804-1853), la nación cubana está constituida por los burgueses blancos, dueños de la industria azucarera ya que son ellos quienes custodian el patrimonio y el progreso.

Ahora bien, tal como ha sido formulada, esta concepción de clase denominada sacarocracia tiene un espesor semántico que articula en su definición al menos dos entidades descriptivas. Por un lado, una condición de clase ligada a una actividad 
económica específica y por otro, una pertenencia étnica-cultural. En este sentido, el término requiere que se lo problematice a la luz de otra categoría no exenta de complejidad: la noción de criollo.

Hay dos aspectos vinculantes de la definición de criollo sobre los cuales conviene detenerse. Por un lado, el surgimiento de los criollos en tanto grupo étnicocultural; por otro, la conciencia diferenciada respecto a otras identidades colectivas que asume este grupo. Cada uno de estos aspectos nos conduce a distintas coyunturas históricas.

Yolanda Martínez-San Miguel (2009) recupera la etimología y la historia de la palabra criollo para repensar el desarrollo que este término clave ha tenido en el seno de los debates identitarios y disciplinarios en el Caribe hispánico y francés. Al respecto señala que las definiciones tradicionales de criollo coinciden en una serie de puntos comunes: (1) se trata de un término que se adoptó en el mundo colonial del contexto portugués y que se usó primero para referirse a los esclavos africanos que habían nacido en las Américas; (2) que más tarde se utiliza para referirse a los descendientes de los europeos que nacían y se criaban en las colonias y (3) este lugar de identificación será clave en una identidad americana diferenciada que generará una serie de discursos proto-nacionales o americanistas que desembocarán en los movimientos de independencia. Razón por la cual, los conceptos de criollo y criollismo son centrales para estudiar el contexto de la formación de los estados nacionales en América Latina (2009: 404).

En la revisión y análisis que Martínez-San Miguel desarrolla sobre la historia del término, advierte que cuando comienza a circular el término criollo (documentado por primera vez en 1560 en una carta del Obispo de Guatemala dirigida al Rey) para hacer referencia a las generaciones que nacen y se crían en el espacio americano, la identidad criolla se define en términos peyorativos en relación a la identidad imperial europea $^{11}$. Aparece asociada al término "indiano" (derivación de Indias, en Covarrubias) y se extiende sobre este concepto una minusvalorización apoyada en la

${ }^{11}$ En efecto, José Juan Arrom (1959) en el artículo "Criollo: definición y matices de un concepto" establece que el uso de la palabra criollo para referirse a los españoles nacidos en las Indias se remonta a la segunda mitad del siglo dieciséis, específicamente, entre 1571 y 1574. 
idea de la degeneración de los europeos que vivían en suelo americano o que nacían en América. Es decir, desde muy temprano los criollos deben confrontar por legitimar su incorporación al orden imperial euro-americano.

En un sentido primero, entonces, la definición de criollo no se relaciona directamente con una designación racial (su acepción más moderna) sino a una categoría geocultural que se fundamentaba en el lugar de nacimiento. Al respecto, Juan José Arrom observó hace ya varias décadas:

No era la pigmentación de la piel ni la condición social lo que caracterizaba al criollo sino haber nacido en el Nuevo Mundo de ascendientes no indígenas, bien fuesen europeos o africanos. Y aclaremos que la condición, esencial y determinante, de haber nacido en el Nuevo Mundo no es mera frase ni simple accidente. La tierra, la vegetación y el clima que los colonos encuentran en el recién descubierto continente son tan distintos a los que habían dejado allende el mar que en el proceso de adaptación a esas nuevas condiciones físicas improvisan soluciones de tipo cultural distintas también de las que dejaron en sus distantes comunidades de origen. El conjunto de esas nuevas soluciones, de ese vivir diferente en una tierra diferente crea por extensión un clima social parecido pero no idéntico al de la vieja patria lejana (1959: 172-173).

Aunque Arrom en su revisión del "desarrollo histórico del vocablo" observa que no está cargada de una connotación racial, sino cultural, es de notar que muchas de las teorías sobre la degeneración intelectual, moral y física del criollo como resultado de su exposición a la cultura y clima americanos, junto con el cuestionamiento de un prestigio social que se adquiere fuera de las nociones de linaje y estamento, sugieren una racialización del sujeto colonial que sí se elaborará ampliamente en el discurso imperial moderno (2009: 407).

Del meticuloso trabajo de Martínez-San Miguel hay otro elemento que consideramos pertinente recuperar: la vinculación entre el vocablo criollo y la raíz latina creare, que sugiere la idea de hacer algo nuevo. En relación a esta probable etimología es posible pensar las nociones de "criollismo" y "creolización" en tanto producciones de una identidad nueva o de algo nuevo que resulta de haber nacido en el suelo americano (408). 
Por otro lado, es necesario considerar la evolución del término en un contexto caribeño, pues coincidimos con Martínez-San Miguel en que el Caribe es una zona geopolítica específica que se ha caracterizado por experimentar varias olas inmigratorias de Europa, Asia y África después de la crisis demográfica ocurrida a pocos años de iniciarse el proceso de colonización. Un resultado directo de estas inmigraciones masivas es que en esta zona surgieron sociedades que se constituyeron casi completamente de poblaciones desplazadas que crearon nuevas culturas "mestizas" o "mulatas". En segundo lugar, el Caribe funcionó como una frontera fracturada que fue el resultado de la colisión e interacción de varios proyectos imperiales y, como tal, su desarrollo histórico difiere de otras zonas de América continental.

Además, la autora señala que la idea de la continuidad del colonialismo después de la independencia no es en el Caribe una alegoría política sino una realidad literal. Cuando la mayoría de Latinoamérica obtiene su independencia muchos de los países del Caribe - excepto Haití y República Dominicana - siguen siendo colonias de varias metrópolis europeas. Por otro lado, el exterminio del sustrato indígena en el siglo dieciséis conlleva a sostener que la noción de lo aborigen, lo autóctono y lo criollo tienen un desarrollo significativamente distinto en esta zona.

Al mismo tiempo, la noción de lo criollo tiene desarrollos independientes en las colonias hispanas, francesas e inglesas y debe diferenciarse del término "creole" utilizado, por lo general, para referirse a la cultura sincretizada y a los dialectos locales que se producen en el Caribe inglés y francés ("pidgins" que se nutren de los diversos elementos europeos, africanos y asiáticos trasplantados a las Antillas y que producen una cultura única $)^{12}$. En el Caribe hispánico, como ya se ha señalado, criollo se refiere a los españoles nacidos en América. Desde fines del siglo diecisiete, los criollos se convirtieron en una especie de sector intermediario que luchó por legitimar su condición hegemónica en las Américas frente a los funcionarios peninsulares que usualmente detentaban cargos de mayor poder y rango. Coincide con esta mirada José Antonio Mazzotti (2009), quien afirma que los criollos encontraron diversas formas de

${ }^{12}$ Para abordar las complejas relaciones sobre criollo y creole y cómo se resignifican estos conceptos son valiosos los aportes de Juan A. Ennis (2013). 
negociar con el poder ultramarino, tratando de acomodarse dentro del sistema burocrático y la organización eclesiástica a través de alianzas con los peninsulares, pero en la mayoría de los casos subrayando sus propios derechos. El reclamo constante por la prelación o preferencia debida a los españoles nativos de los reinos de Ultramar estuvo presente en casi todas las instancias de la vida cotidiana y jurídica (2009: 465).

También Mabel Moraña (1988) sostiene que en el siglo diecisiete se origina el germen de una conciencia criolla americana que utiliza el aparato retórico del Barroco de Indias para exponer una incipiente alteridad contrahegemónica. Según su mirada, el Barroco de Indias, como dispositivo discursivo, permite a los criollos de la colonia que ocupan un lugar de subalternidad desplegar una serie de estrategias de enmascaramiento, "tretas del débil" (tal cual las enuncia Ludmer, 1984) a partir de las cuales se modifican y se desplazan las posiciones de enunciación del sujeto colonial. Entonces, según esta tesitura, emerge una conciencia criolla americana que utiliza el Barroco para ocupar otros lugares de enunciación que difieren de lo hegemónico y establecido y para denunciar el aparato represivo y disciplinante del Estado. En el mismo enfoque, en el ámbito de las letras cubanas, José Lezama Lima en su ensayo "De la curiosidad barroca" en La expresión americana (1957) ya había señalado que "podemos decir que entre nosotros el barroco fue un arte de la contraconquista" (1993: 170). En el mismo ensayo, páginas más adelante, Lezama Lima deja advertir en su metaforización la relación entre criollo y barroco al decir que "el señor barroco americano, a quien hemos llamado auténtico primer instalado en lo nuestro, participa, vigila y cuida las dos grandes síntesis que están en la raíz del barroco americano, la hispano incaica y la hispano negroide" (195).

En los procesos de formación de los Estados nacionales, la configuración del elemento criollo se vincula directamente con los proyectos de inclusión o exclusión propuestos desde la retórica del mestizaje. En este sentido, la independencia de Haití en 1804 marca un hito como primera república negra cuando en la constitución de 1805 define a sus ciudadanos como sujetos negros ${ }^{13}$. En el caso cubano, primero será

\footnotetext{
${ }^{13}$ Es insoslayable para comprender el proceso de la Revolución haitiana y su relación paradójica con la Modernidad (entendida en términos eurocéntricos) detenerse en el libro de Eduardo Grüner (2010) La oscuridad y las luces. Capitalismo, cultura y revolución. Como señala Grüner, la Revolución de Haití produjo el primer "gran discurso" de lo que se podría denominar una contra-modernidad En este
} 
la criollidad blanca y culturalmente española la que articule el discurso patriótico. Luego, ya casi sobre el final del siglo, José Martí ("Nuestra América" 1891) propondrá un discurso de integración nacional de lo criollo y lo mulato, que se consolidará en el siglo veinte a partir de la recuperación y valoración de los elementos africanos como parte definitoria de la cubanidad que realiza Fernando Ortiz (1881-1969) en los numerosos ensayos en los cuales aborda el impacto de la población negra en la constitución de lo cubano ${ }^{14}$.

En Los negros brujos (1906), Ortiz inicia un profundo y extenso sondeo de lo que denominó "afrocubanía". Desde el prólogo de la primera edición se advierte el encuadre del trabajo en las líneas de la llamada antropología criminal que funda César Lombroso (1835-1909). De este modo, Ortiz propone un acercamiento metódico y positivista respecto del hampa cubana, centrando su estudio en la descripción de los vicios de la raza negra por considerarlos peculiares y distintivos de la "mala vida habanera". No obstante esta focalización, desde las primeras páginas, Ortiz señala la complejidad del tema al expresar la heterogeneidad de la sociedad cubana:

Casi contemporáneamente con la raza blanca, llegó a Cuba la raza negra, pero su importación no fue considerable hasta que, por el impulso dado por los inmigrantes blancos a la vida económica del país, se dejó sentir extraordinariamente la necesidad de brazos para las plantaciones, de tal manera que al mediar el siglo XIX hubo en Cuba más negros que blancos. (...) También a mediados de la última centuria entró en Cuba la raza amarilla, llegando a contarse en 1862 más de 60.000 chinos. (...) Vinieron todavía a completar el mosaico étnico de Cuba los indígenas de Yucatán, más en cantidad tan reducida que apenas han dejado recuerdo de su paso (1995: 10).

\footnotetext{
sentido, "la esclavitud afroamericana y la Revolución haitiana produjeron un importante impacto en el pensamiento contractualista, iluminista y crítico en la filosofía y la teoría política de los países 'centrales', rol que fue sistemáticamente excluido o negado desde la Teoría Crítica" (29). Justamente, de reparar esa omisión y de interpretarla se ocupa Grüner en este extenso ensayo en el cual no solo recupera la historia (es decir, la construcción de un gran relato) sino también analiza las marcas poético literarias que ha dejado la Revolución haitiana.

${ }^{14}$ Para profundizar sobre este tema se pueden consultar los numerosos artículos de la Dra. Alejandra Mailhe quien ha abordado el lugar paradigmático de los intelectuales en Cuba, Brasil y Argentina a principios del siglo veinte.
} 
En 1916, en Los negros esclavos, Fernando Ortiz toma distancia de la perspectiva lombrosiana al señalar y describir las características de la esclavitud como sistema ligado al régimen de plantaciones en América. En esta obra denuncia el padecimiento que sufren los esclavos africanos cuando se inicia la trata negrera.

Si bien, estos estudios distan temporal e ideológicamente entre sí, poniendo en evidencia los cambios acontecidos en el campo de la Antropología y, en particular, el circunspecto al ámbito de las investigaciones etnográficas, lo peculiar es que en ambas obras se hace hincapié en señalar la heterogeneidad como rasgo distintivo de la cubanidad, no sólo al describir la composición de la sociedad del siglo diecinueve sino al indicar las diferentes etnias y grupos raciales aglutinados bajo la figura del esclavo africano.

A partir de la década del treinta, se produce un cambio en la mirada sobre el elemento negro, pues pasa a ser concebido como símbolo de autoctonía. Esta concepción del afrocubano debe comprenderse a la luz de otros fenómenos como el surgimiento del Grupo Minorista (1923-1928) que desempeña un papel muy importante en la difusión de la cultura afrocubana (Manzoni 2001).

En este sentido, la concepción de lo heterogéneo como rasgo distintivo de la cubanía fraguará en el ineludible ensayo de Fernando Ortiz publicado en 1946, Contrapunteo cubano del tabaco y del azúcar, en el cual expone, a partir del contraste entre estos dos productos, su teoría de la transculturación para explicar el proceso de constitución de la sociedad cubana:

Hemos escogido el vocablo de la transculturación para expresar los variadísimos fenómenos que se originan en Cuba por las complejísimas transmutaciones de culturas que aquí se verifican, si conocer las cuales es imposible entender la evolución del pueblo cubano, así en lo económico como en lo institucional, jurídico, ético, religioso, artístico, lingüístico, sexual y en los demás aspectos de la vida (1999: 80).

Una primera aproximación sobre esta idea es presentada por Ortiz en 1939, en una conferencia que ofrece en la Universidad de La Habana, bajo el título "Los factores humanos de la cubanidad"15. En esta oportunidad propone la metáfora culinaria del

\footnotetext{
${ }^{15}$ Esta conferencia fue publicada en 1840 en la Revista Bimestre Cubana.
} 
"ajiaco" para simbolizar la mezcla que implica la conservación de los elementos y, al mismo tiempo, la transformación en algo diferente, original.

El concepto de transculturación propuesto por Fernando Ortiz integra la diferencia y genera, a partir de esta mezcla, algo nuevo. Sus aportes se corresponden con una nueva valoración del mestizaje que surge entre las décadas de 1920-1930 y guarda relación con la necesidad de generar una fórmula unificadora que permita la formación de la nacionalidad ${ }^{16}$. En este sentido, sus aportes nos sirven para pensar distintas etapas del proyecto de construcción nacional cubano, que van desde la negación del componente negro y su exclusión, a la idea de que lo negro está en el sustrato social y étnico de manera ineluctable, pues es recíproca la modificación que se produce en el contacto entre etnias y culturas diferentes. Sin embargo, debemos al menos señalar que su tesis ha sido ampliamente debatida a partir de considerar que la conquista y colonización de América no ha sido un "encuentro de culturas" sino un "choque" signado por el sometimiento de unas sobre otras. Este carácter opresor y traumático no es considerado desde su teorización, pues explica el mestizaje como un proceso inofensivo. Para Cécile Leclercq tanto sus primeros enfoques positivistas como el enfoque culturalista del Contrapunteo "son dos polos de una misma ideología blanqueadora" (2004: 465).

Otra mirada que nos permite dilucidar la categoría de criollo la aporta Antonio Benítez Rojo, quien toma en consideración una perspectiva de anclaje y problematización más amplia: el Caribe como constructo "saturado de mensajes", en el cual "insularidad" y "archipiélago" deben entenderse como puentes y como fragmentos al mismo tiempo: lo inestable, lo discontinuo, lo turbulento, el Caos como des-orden, como marca definitoria que se reitera. Bajo esta perspectiva, en La isla que se repite. El caribe y la perspectiva posmoderna (1989), Benítez Rojo sitúa en el siglo diecisiete la emergencia de una cultura criolla caribeña ligada a la exportación de cueros: actividad que adquiere suma importancia militar, naval, doméstica y artesanal para la economía de las Antillas, y en especial para La Española (actualmente República

\footnotetext{
${ }^{16}$ La fórmula del mestizaje integrador aparece en otras regiones de América Latina, por mencionar solo algunos ejemplos, en México La raza cósmica (1925) de José Vasconcelos; en Brasil podemos señalar en esta perspectiva dos obras: Macumaína (1928) de Mario de Andrade y Casa-grande e senzala (1933) de Gilberto Freyre.
} 
Dominicana y Haití). Como señala Benítez Rojo, la producción de cuero era totalmente diferente a la del azúcar, pues era abordable por cualquier colono tierra adentro, no requería costosas máquinas ni equipos, no requería de la administración de la colonia, era, en resumen, una industria pequeña pero estable. La población que residía al norte de La Española, la llamada "banda norte", era la más beneficiada para llevar adelante esta industria pues el ganado se concentraba en estado salvaje lejos de la capital y de las villas principales. Estos poblados elevaron numerosas solicitudes a la Corona para poder comercializar el cuero en los puertos de la región, pero estas peticiones fueron desoídas, lo que trajo como consecuencia el comercio de contrabando, llamado entonces de "rescate", con mercaderes provenientes de potencias rivales de España. En síntesis, la abundancia de ganado, la alta demanda del cuero, la expansión mercantil de las potencias rivales y la renuencia de la Corona a conceder libertades comerciales contribuyeron a conformar un tipo particular de sociedad colonial en las zonas occidental y norte de La Española. Se trataba de gente emprendedora, en gran medida, de mestizos y mulatos, que por vivir lejos de las ciudades estaban fuera de la órbita de la burocracia colonial, de las guarniciones coloniales y de la vigilancia de la Iglesia. Constituían un grupo social de "nuevos ricos", dentro de la esfera comercial de la Europa capitalista, no previsto en las disposiciones del Consejo de Indias o en las cédulas reales; subsistían de modo autosuficiente, de espaldas a la metrópoli y a la capital insular. Si bien importaban esclavos, no constituían, como aclara Benítez Rojo, "una sociedad negrera en el sentido económico de la palabra, es decir, en el sentido que la Plantación le confiere al término" (1989: 18).

En esa matriz socioeconómica, las relaciones humanas tenderían a ser más individualistas, más dinámicas. Benítez Rojo ubica en esta sociedad de "tipo ambulatoria”, de costumbres libres, regida solo por el interés común del contrabando y separada de los centros de poder colonial, el surgimiento de los "criollos propiamente dichos, también llamados significativamente, gente de la tierra" (18).

En el marco de esta temprana sociedad criolla, localizada en zonas aisladas de las Antillas y del litoral caribeño, el esclavo africano desempeñó un rol activísimo en el 
proceso de la formación de las culturas locales. A diferencia del negro del ingenio ${ }^{17}$, el esclavo inscripto dentro de la economía del cuero no se hallaba sujeto a un régimen de reclusión y de trabajo forzado, y por tanto, tuvo la posibilidad de aculturar al europeo de una forma acentuada. En palabras de Benítez Rojo:

Ciertamente, estas sociedades marginales de criollos, presentes en otros sitios del Caribe, no constituyeron ninguna arcadia colonial, sobre todo para el esclavo, al fin y al cabo, arrancado de lo suyo. Pero el interplay de pluralismos etnológicos, en un escenario social más abierto que el que proveía la capital, y las plantaciones, hizo posible que surgiera allí un tipo racial generalizado de ascendencia taína, europea y africana, que era receptor y difusor a la vez de una cultura supersincrética caracterizada por su complejidad, su individualismo y su instabilidad, esto es, la cultura criolla, cuyas semillas se extraviaban en las venas profundas de tres continentes (1989: 19)

Estas tempranas sociedades criollas, no azucareras, entraron en conflicto con la burocracia colonial pues el comercio ilícito privaba de las ganancias al gobierno. Como consecuencia, la Corona impulsó drásticas represalias que desencadenaron cuantiosas pérdidas económicas y de población, pues estas regiones del norte quedaron prácticamente desiertas. A razón de las “devastaciones” que acarreó la persecución y ejecución de los grupos que comercializaban clandestinamente esta incipiente cultura criolla se desarticuló y su transformación se hizo más lenta y sus diferencias, menos radicales (1989: 24).

La cultura criolla propia de Cuba se gestó en la región oriental de la isla, en íntima conexión con la banda del norte. De manera semejante a lo que ocurriera en La Española, el único puerto de Cuba autorizado para comerciar era el de La Habana, lo cual marcaría visibles diferencias entre las regiones occidentales y orientales de esta colonia. La Habana, por su proximidad a la Corriente del Golfo y por estar situada frente al Estrecho de la Florida entró en el sistema de flotas, lo que la convertiría en una de las ciudades más visitada del Caribe. En cambio, las regiones orientales de Cuba presentaban otro cuadro. Excluidas de los beneficios del gran comercio y

\footnotetext{
${ }^{17}$ Se usa esta expresión sin connotaciones peyorativas, tal como la emplea Antonio Benítez Rojo en su ensayo, cuyo contenido estamos recuperando en esta parte del capítulo. Aclaramos que en este trabajo respetamos las denominaciones que utilizan los autores críticos consultados y, en todo caso, se señalará el propio distanciamiento en nota al pie.
} 
separadas de La Habana por centenares de millas de bosques cerrados, iniciaron una economía ganadera paralela a la de La Española (1989: 25).

Sin embargo, cuando ya estaban decretadas las órdenes para reprimir a los criollos de las comarcas orientales acusados de contrabandistas, fue secuestrado por un corsario el Obispo Cabezas Altamirano y los criollos orientales lo rescataron, razón por la cual, éste intercedió ante la Corona para que los contrabandistas de Cuba no sufrieran el mismo castigo que los de La Española. De este modo, habitantes de la región continuaron contrabandeando hasta bien entrado el siglo diecinueve.

Merece al menos una breve mención señalar que lo acontecido en relación al secuestro del Obispo y el combate de los criollos cubanos contra el corsario francés dieron origen a la composición de Silvestre de Balboa (1563-1647) Espejo de paciencia, obra en la que por primera vez aparece la palabra "criollo" aplicada al héroe protagonista, un negro esclavo llamado Salvador. Para Benítez Rojo, como para otros críticos, este es el primer poema cubano que expresa dentro de la literatura del Caribe un deseo de igualdad racial, social y cultural, pues "en las filas locales pelean en igualdad de condición racial" (26) y es el esclavo Salvador quien libera al Obispo y obtiene la libertad. Cabe destacar que este poema se mantuvo oculto y sobrevivió al incendio de la villa en 1616. El manuscrito recién fue encontrado en 1836 por José Antonio Echeverría en los archivos de la Sociedad Patriótica de La Habana y publicado dos años más tarde en El Plantel, periódico que funda Domingo del Monte. Como sostiene Carlos Rovira “Espejo de paciencia no fue contemporáneo de los cubanos del siglo XVII, en cuyos comienzos se escribió, puesto que no pudieron conocerlo, pero empezó a ser contemporáneo de los cubanos del siglo XIX” (2000: 35$)^{18}$.

No es casual que se publique en este periodo ni que sea bajo la órbita del grupo de Del Monte, pues tanto el poema de Balboa como los seis sonetos que lo acompañan

\footnotetext{
${ }^{18}$ Un estudio a consultar es el que realiza Luis Duno Gottberg (2003) en "Las diferencias ante el Espejo: la lectura decimonónica de Espejo de Paciencia", incluido en la "Primera Parte" de su libro Solventando las diferencias. La ideología del mestizaje en Cuba. En este capítulo el autor sostiene que el proceso de relectura podría responder a la necesidad de ubicar y regular la presencia de un elemento étnico que se percibe como discordante: lo afrocubano. Se trata de observar - dice el autor - en este caso "cómo la celebración del poema de Balboa por parte del grupo de intelectuales abolicionistas que rodearon a Del Monte responde a tales necesidades mediante la creación del universo simbólico que pretende resolver los conflictos raciales bajo el metarrelato de la hermandad protonacional de lo cubano" (45).
} 
evocan al criollo de las sierras, a la naturaleza, a la fauna y a la flora locales. No habla de España sino de Cuba: de Puerto Príncipe, de Bayamo, de Yara y Manzanillo ${ }^{19}$.

Este poema, escrito tres siglos antes, aparece en el tercer decenio del siglo diecinueve como un texto que permite fundar un origen de literatura, un linaje, un punto de partida. Del mismo modo que Espejo de paciencia irrumpe como texto articulador en una coyuntura de organización de lo nacional y de lo cubano, cada vez que se produzcan en la historia cubana procesos que conlleven a la pregunta sobre la nacionalidad, se reactualizarán las lecturas sobre esta obra:

(...) la idea es en cualquier caso básica para el imaginario nacional cubano. Y es básica en cuanto se empieza a conformar a fines de siglo XIX mediante el reflejo en el espejo de Balboa de la erudición antigua y aburrida de Menéndez Pelayo o de José María Chacón y Calvo, de la erudición menos antigua pero a veces también aburrida de José Pichardo Moya o de Cintio Vitier, o más recientemente de las imágenes profesorales de Schulmann, González Echevarría y Juana Goergen. También la genialidad, confusa o clara, gongorina o vanguardista, verdadera o falsa (o no) de José Lezama Lima. Lo sorprendente es que, desde finales del siglo XIX, un canario-cubano de tres siglos antes pudiera crear una imagen tan erudita, tan épica, tan tópica, tan recurrente y de una poética tan torpe con la que todavía podemos hoy acercarnos, seguramente por la extrañeza lezamiana de su título, a una era imaginaria de la formación de la nacionalidad cubana (Rovira 2000: 42).

En síntesis y para retomar el análisis de Benítez Rojo, esta cultura criolla- que se autoreconoce como tal en la literatura, ligada en sus orígenes a la economía ilícita del cuero produjo notables manifestaciones religiosas (Virgen del Cobre), literarias (Balboa), musicales (chacona y zarabanda) y culinarias (ajiaco). Por ende, para el crítico cubano, el valor cultural de estos primeros criollos reside en las manifestaciones

\footnotetext{
${ }^{19}$ Por lo general, la tradición crítica ubica a esta obra como el primer texto literario "auténticamente cubano". Este texto primigenio es una referencia ineludible en casi todos los trabajos que indagan en la configuración de la literatura y de la identidad cubana. Entre los críticos cubanos se destaca el análisis de Felipe Pichardo Moya, Cintio Vitier (quien le dedica al poema de Balboa el inicio de su ensayo Lo cubano en la poesía, 1958) y José Lezama Lima. En un trabajo excelente, Carlos Rovira (2000) analiza la "función fundacional" que la obra de Balboa ejerció sobre la configuración del imaginario cubano.
} 
supersincréticas que elaboran y que conducirán en el periodo de apogeo de lo criollo a la formación de un deseo de nacionalidad (1989: 28). Sin dudas, podemos reconocer en esta idea cierta vigencia del "ajiaco" ortiziano.

Este momento de auge cultural de lo criollo coincide en Cuba con el tránsito hacia a la Plantación, proceso que impacta en la fisonomía cultural y geográfica de la isla y configura lo que Benítez Rojo denomina "Dos Cubas": una "Cuba grande", marcada por los intereses de la poderosa y fagocitante industria del azúcar, que geográficamente se localiza alrededor de La Habana e invade en poco tiempo las tierras centrales y occidentales; y una "Cuba chiquita" que se corresponde con los intereses criollos de las regiones no azucareras, y que se localiza en la banda oriental. Mientras que la plantación azucarera exigía grandes cantidades de tierra, por ser un cultivo de tipo extensivo, importaciones masivas de esclavos y la protección comercial, militar y administrativa de España, el sector criollo fuera de la plantación poseía o usufructuaba las tierras de más rendimiento, no era un sector esencialmente esclavista y carecía de influencia política por estar alejado de La Habana.

Como ya hemos señalado, la sacarocracia, entendida como la clase criolla que emerge con la industria del ingenio se distingue de la cepa más antigua de los criollos orientales. Su distinción radica en la situación ambivalente de este grupo que gravitaba en torno a sentimientos contradictorios respecto de los deseos de independencia y el temor a conceder la libertad a los esclavos y caer en la ruina económica. El poder azucarero criollo residió en su sociedad con la metrópoli dentro de las relaciones económicas conectadas al sistema capitalista europeo, lo cual tendía a reforzar el grado de dependencia. En resumen, es esta diferencia la que permite comprender por qué motivo solo los criollos de las provincias orientales y centrales participaron en las luchas por la independencia.

Según la tesitura de Benítez Rojo, la presencia de los criollos desde el siglo diecisiete conlleva a sostener que hacia 1830 es posible hablar de un verdadero sustrato criollo cubano que comienza a tomar conciencia de su identidad y a reclamar derechos de ciudadanía y gobernabilidad.

La demarcación y postulación de la identidad criolla cubana está directamente vinculada a la estrategia de la afirmación de la autonomía de Cuba. Pues la conciencia 
de una cultura propia resulta ser el primer paso hacia el posterior desarrollo de la madurez de la identidad nacional, es más, es la condición sine qua non. En su proceso de identificación, la primera etapa para los criollos cubanos consistió en la voluntad de marcar el límite entre los peninsulares y ellos mismos. Esta traza de una "frontera", en términos de F. Barth ${ }^{20}$, supone la voluntad de parte de una colectividad de diferenciarse de otra y la utilización de ciertos rasgos culturales como marcadores de su identidad específica. Una colectividad culturalmente cercana a otra - como era la comunidad criolla de Cuba tan cercana culturalmente a la de los peninsulares - puede considerarse como extraña a la otra, en este caso, a la española, oponiéndose sobre uno o varios elementos aislados del conjunto cultural que une a las dos colectividades: a las leves diferencias de los usos y costumbres entre criollos y peninsulares, se añadieron las diferencias climático-geográficas y las referencias a la historia embrionaria, pero propia. Es decir, la diferencia postulada era arbitraria y sobre todo psicológica: la originaban el recelo de las autoridades coloniales así como las tensiones comerciales y económicas que acentuaron la disparidad. Los criollos empezaron entonces a querer diferenciarse de los españoles, identificándose con el amor a su tierra, su historia y el hecho de ser criollos.

Al respecto, Cécile Leclercq postula que la manifestación de una criollidad, tal como la referimos, es uno de los elementos que permite distinguir y diferenciar a Cuba del resto de las islas del Caribe. Esta peculiaridad la nota en el sentimiento patriótico que expone la sacarocracia. A diferencia de otras islas caribeñas, la oligarquía ligada a la producción del azúcar no sentía a Cuba como mero lugar de retiro y placer, sino como la patria, pues sus padres habían nacido allí y querían vivir y morir en esa tierra. De esta forma los criollos blancos se distinguían de los peninsulares que solo se dedicaban a buscar fortuna en la isla y de otros grupos criollos de las Antillas que consideraban a las islas como factorías.

Este sentimiento de pertenencia se advierte cuando se produjo la revolución azucarera en Cuba y fueron los criollos cubanos (no los españoles) quienes financiaron la modernización del proceso de producción del azúcar, generando una economía de

${ }^{20}$ Remitimos a los postulados teóricos desarrollados por Fredrik Barth en la "Introducción" de Los grupos étnicos y sus fronteras. La organización social de las diferencias culturales (1976). 
plantación azucarera moderna. En esta coyuntura de enriquecimiento y poder, la sacarocracia y la burguesía cubanas siguieron viviendo en la isla. Si bien las fincas de los ingenios no eran su residencia permanente, pues solo eran utilizadas como recintos para vacacionar, estas familias vivían en las ciudades como La Habana, Matanzas, Santiago de Cuba o Camagüey. Estas clases pudientes tenían dinero y lo gastaban e invertían en Cuba, a diferencia de los plantadores europeos de las Antillas pequeñas (holandesas, francesas o inglesas) que gastaban su dinero en las respectivas metrópolis y que además practicaban el absentismo, encargando sus ingenios a gerentes europeos (Leclercq 2004: 140).

El primer proyecto de autodefinición cultural fue aprehendido primeramente como diferenciación de España. Como ya se ha mencionado, fueron los letrados quienes articularon ideológicamente esta diferenciación. La preocupación central de los escritores e intelectuales criollos fue la búsqueda de una definición singular de su cultura en alteridad con la metrópoli. Además de distinguirse mediante referencias al medio ambiente natural insular suyo y a la historia, destacaron un modo de vivir distinto, su cultura criolla. La afirmación de la diferencia cultural mediante la definición de lo criollo resultó — como afirma Leclercq — " "una empresa ardua, pues los criollos descendientes de los españoles hablaban el mismo idioma, practicaban la misma religión y compartían el mismo sistema de valores" (320).

La diferenciación puesta de manifiesto por los criollos cubanos destacaba detalles vinculados con la especificidad de la naturaleza, el clima y la historia incipiente $^{21}$. No es casual, entonces, que la literatura exprese esa voluntad diferenciadora y que los cuadros de costumbres busquen traducir ese sentimiento de pertenencia cultural criolla.

\footnotetext{
${ }^{21}$ En el ya citado trabajo de Juan José Arrom se desarrolla una cronología de la historia del vocablo que revela no solo el acento cultural del concepto (por sobre el racial) sino las diferencias que tempranamente separan a los nacidos en el Nuevo Mundo en relación a los españoles peninsulares y a los recién llegados al suelo americano. Arrom trae a colación ejemplos de Juan de Cárdenas, Problemas y secretos maravillosos de las Indias, 1591 quien dedica un capítulo a explicar las diferencias en modales, expresiones verbales y actitud mental que distinguían al nacido en Indias del cachupín o rezín venido de España. Las mismas cualidades las enumera Bernardo de Valbuena en Grandeza Mexicana, 1604. Otra obra, también de 1604 que instala las diferencias entre nativos de América y españoles peninsulares es Sumaria relación de las cosas de Nueva España, del criollo Baltasar Dorantes de Carranza.
} 
Aparecen entonces las referencias en artículos de prensa, cuentos, relatos y novelas sobre la vida diaria de los criollos: hábitos, modos de actuar y de vestirse, consumos, etc. Con la difusión, en diversos escritos y medios, del comportamiento del criollo se buscaba edificar la identidad colectiva propia que pusiera en evidencia la diferencia con los peninsulares.

El descubrimiento del país por parte de los criollos, la tentativa de indagar su medio, de definir su historia propia y el deseo de aclarar la posición de su cultura respecto de España, son aspectos de la autodefinición de la cubanidad que desembocan en el siglo diecinueve en un sentimiento de patria y, luego, en una conciencia de nación.

Sin embargo, este proceso de diferenciación tuvo un trasfondo económico. El vínculo entre Cuba y España no era solamente cultural, sino también un pacto político que consistía en que Cuba debía pagar fuertes impuestos a España, recibiendo a cambio la garantía de un aparato represivo, pagado por los cubanos mismos, para eventuales sublevaciones de esclavos. La expansión económica desencadenó una transformación de las relaciones con la metrópoli, pues, como ya hemos señalado, la revolución azucarera incentivó que la oligarquía criolla defendiera sus intereses y exigiera mayores derechos a la Madre Patria. Como este reclamo de mayor poder no fue concedido, se suscitó una confrontación con el poder colonial, de ahí surge la necesidad de distinción y autodefinición de la sociedad criolla cubana. No obstante, para evitar una confrontación directa, la élite criolla asumió una postura reformista que permaneció hasta la Guerra Grande. El sector criollo se constituyó como un contrapoder, ya que de las limitaciones comerciales y políticas impuestas por el gobierno colonial surgieron las primeras manifestaciones de contradicción entre criollos y españoles. Por ende, los criollos cubanos fueron conformando un nuevo universo, diferenciado del español, principalmente sobre la base de una economía propia. A pesar del interés en diferenciarse de los españoles, los criollos cubanos de la primera mitad del siglo diecinueve no albergaron intenciones de una ruptura política, de ahí el carácter reformista de la Ilustración criolla que representaba los intereses de la sacarocracia. 
En consecuencia, Cuba tuvo tiempo de adquirir un sólido sustrato cultural criollo, pues España mantuvo el control político, administrativo y económico hasta 1898. El desarrollo diferido de la explotación azucarera favoreció en Cuba la consolidación de una cultura criolla, que delimitó en el siglo diecinueve un imaginario patriótico sustentado en una doble diferenciación: hacia los españoles peninsulares y hacia el componente africano.

En síntesis, como coinciden todos los críticos, el azúcar en Cuba interfirió directamente en la constitución de una conciencia nacional: por una parte difirió la Independencia, pues fuera del ala independentista de los años veinte del siglo diecinueve, los terratenientes esclavistas no pretendieron constituir una nación independiente hasta 1868 , y por otra parte, generó una atomización de la sociedad cubana y de la cubanidad, en las cual se pueden destacar rivalidad entre sacarócratas y la vieja aristocracia criolla (dedicada a otros cultivos, como el tabaco y el café), así como entre criollos y peninsulares. Sin embargo, pese a las diferencias entre estos grupos, los proyectos de construcción de la nación cubana se apoyaban, más bien, sobre el antagonismo entre amos y esclavos y, más tarde, entre blancos y negros.

En las páginas que siguen abordaremos los proyectos patrióticos perfilados desde la sacarocracia.

\subsubsection{Dulces poderes en juego: el grupo reformista ilustrado y la configuración de lo nacional}

En la configuración de las matrices simbólicas que definen la identidad cubana se entroncan dos posturas diferentes que responden a facciones políticas e ideológicas que articulan dos discursos opuestos. Por un lado, las fuerzas que se podrían denominar más conservadoras, partidarias de mantener vigente la tradición hispánica, y por otro, aquellas vinculadas de modo incipiente con las corrientes liberales y alentadas por las ideas del Positivismo. Al respecto, los estudios que analizan la conformación de las propuestas liberales en Cuba en el siglo diecinueve (Bernal Gómez 1997; García Mora 2001; Aguilera-Manzano 2007) advierten sobre la complejidad del proceso constitutivo de las distintas facciones ideológicas. Los intereses disímiles explican las 
fragmentaciones y reorganizaciones de los grupos, en tanto que la relación que mantienen los letrados involucrados con el contexto político-económico permite distinguir las distintas etapas que atraviesa el pensamiento liberal cubano.

No es el objeto de esta investigación escudriñar en tales diferencias sino poder describir qué perspectivas originan determinadas estructuras de interpretación y construcción de sentido. Si consideramos la doble distinción formulada en párrafos anteriores, es posible señalar en la configuración de la cubanidad dos grandes modelos culturales. Uno de ellos es el modelo hispánico tradicional, sustentado por los criollos que mantienen vínculos culturales, religiosos y políticos con la metrópoli española. El otro, se relaciona con el modelo anglosajón que considera a Inglaterra y a Francia como los mejores ejemplos de una Europa “esclarecida, civilizada y moderna” (Dávila 2005).

Entre las posiciones más conservadoras y las liberales median los cambios sociales, políticos y económicos que traen aparejados la conversión de Cuba de una sociedad de colonos en una sociedad de plantación profundamente segmentada. El apoyo activo de la Corona hispana, que en 1789 permite la importación libre de esclavos para ser usados como mano de obra y los adelantos tecnológicos que ofrecían nuevos equipos y conocimientos, dieron el impulso para que Cuba se convierta en poco tiempo en el ingenio más poderoso del Caribe. La industria azucarera generó riquezas al mismo tiempo que cambios demográficos. El ingreso de esclavos a la isla aumentó de 1827 a 1840, un $46 \%$ (casi medio millar de esclavos) puesto que la importación de la primera máquina a vapor produjo un recrudecimiento de la explotación esclavista, dado que la gran capacidad de molienda de ésta aumentó en proporciones gigantescas el trabajo de los esclavos en los ingenios (Ortiz [1946] 1995; Leclercq 2004).

Como consecuencia, la revolución agrícola creó nuevas fuerzas y tensiones en la estructura institucional y social, ya que tuvo el efecto político de subordinar la burocracia y los descendientes de españoles de "vieja cepa" a una nueva clase poderosa de plantadores y negociantes, quienes adquirían títulos nobiliarios y se convertían 
rápidamente en el sector más poderoso de la sociedad cubana, tanto que, hacia 1830, el orden establecido por la vieja sociedad criolla había sido casi destruido ${ }^{22}$.

La fragmentación de la sociedad cubana como resultado de las profundas y drásticas transformaciones económicas se expresó en la clasificación de la sociedad de acuerdo con diferentes criterios, tales como: 1) la condición civil, en hombres libres y esclavos; 2) los esclavos a su vez se clasificaron en criollos, bozales y ladinos, agrupados y distinguidos por edades en "piezas de indias", "mulecones" y "muleques"; 3) por el color de la piel, se distinguieron en blancos, negros y mulatos, a este criterio "racial” se sumó el grupo asiático, compuesto por la inmigración china, la cual también fue sometida a la esclavitud por un tiempo; 4) por el lugar de procedencia de los blancos, en criollos y peninsulares; 5) a su vez, los criollos blancos se clasificaron por el lugar de procedencia; 6) por la posición económica, en pobres y ricos, entre tantas otras divisiones que podrían enumerarse (Ortiz [1946]1995; Santamaría García-Orovio 2005).

La heterogeneidad social y racial aparece como el principal obstáculo al que se enfrentan los letrados para la edificación de una patria unida, precisamente porque esa heterogeneidad torna visible las contradicciones ideológicas que impregnan la retórica de las élites ilustradas, es decir, la separación entre los postulados filosóficos y las intervenciones concretas y materiales vinculadas al ingenio. Al respecto, como sostiene el crítico cubano Benítez Rojo,

Es el azúcar lo que ha determinado la geografía política de la isla y su composición demográfica, y lo que ha moldeado su historia económica, social y cultural. El azúcar, de una manera más o menos aparente, ha sido el móvil más poderoso de toda guerra, de toda intervención, de toda revolución, de toda crisis y de todo bienestar (1988: 198).

\footnotetext{
22 Respecto del uso del concepto de clase, como advierten Antonio Santamaría y Consuelo Naranjo Orovio (2005), continúa sin definirse qué tipo de sociedad era la cubana en el siglo diecinueve y, sobre todo, en el último cuarto del mismo. Mientras unos autores la califican como una sociedad de clases, en la que la genética establecía la jerarquía y un sistema de relaciones de "raza", otros prefieren hablar de sociedad de castas pues, aunque reconocen la existencia de clases, creen que estaba encastada por la esclavitud.
} 
Como ya se ha mencionado, es esta omnipresencia del ingenio entendida como una "célula socio-económica autónoma" en la que se concentra el conocimiento técnico, administrativo y mercantil, la que genera la división profunda entre "dos Cubas". En la "Cuba Pequeña o chiquita", que mira hacia el interior, la tierra, heredera de lo criollo surgen los primeros discursos científicos y poéticos de lo cubano. En esta coyuntura deben situarse las producciones ensayísticas y literarias del grupo ilustrado reformista (cuyas ideas se basan en el Contrato Social y en el Régimen de Propiedad), grupo elitista en el que se destacan las figuras de Domingo del Monte y José Antonio Saco. Ellos fueron quienes en medio del discurso hegemónico de "Cuba como un gran ingenio" propusieron la abolición de la esclavitud, la retórica del mestizaje tendiente al blanqueamiento y la revalorización del criollo, como estrategias para solucionar el problema de la heterogeneidad racial que traía aparejada la importación de mano de obra esclava africana. En este sentido, asignaron al "guajiro" criollo blanco, los ideales del hombre cubano que trabajaba la pequeña tierra, invadida y amenazada por el poderoso monocultivo del azúcar.

En el plano literario, nos interesa destacar que Domingo del Monte alentará entre sus coetáneos la escritura de romances de tema cubano, con este gesto reactualiza un género de larga trayectoria al cual le asigna un contenido y un valor: la vehiculización del sentir patrio. Sobre este aspecto profundizaremos en los capítulos III y IV.

Si bien existe una correspondencia entre la propuesta de poner fin a una práctica considerada bárbara como la de la esclavitud con el anhelo de "ingresar" en la Modernidad, el discurso abolicionista ilustrado, disperso en una multiplicidad de textos ensayísticos y literarios, se halla minado de contradicciones, puesto que si bien se evidencia en esos discursos una fractura de la hegemonía del orden jurídico y simbólico de la esclavitud, al mismo tiempo se observa cómo todo el proceso racionalizador que promueve el paso de la colonia esclavista a una nación moderna estigmatiza fóbicamente la heterogeneidad racial y lingüística que domina a la isla (Kutzinski 1993; Ramos 1996; Duno Gottberg 2003; Leclercq 2004; Grüner 2010). 
La actividad desarrollada por Del Monte y el grupo de letrados que lo acompaña $^{23}$ fue consciente y destinada a justificar el reclamo de independencia elevado por $\mathrm{Cuba}^{24}$, proponiendo la conformación de una "nación unida y sin diferencias", razón por la cual se hacía imprescindible superar el temor a la población negra que se instaló luego de la revolución de Haití (1879-1804). Por consiguiente, "la intelectualidad de los años posteriores a 1820 se organizó en torno a la creación de estrategias para aplacar el fantasma de Haití inventando un lugar para el negro en los emergentes discursos cubanos" (Vera-León 1991: 15). En este sentido, la literatura de los letrados reformistas operó como una política desplazada y traducida a los conflictos de la escritura. De este modo, el discurso literario se transformó en la paleta de ensayo de los proyectos nacionales de carácter independentista.

Como ya se ha anticipado, la producción ensayística y literaria de Domingo del Monte se ancla en la "Cuba chiquita", en un pasado pre-industrial, que mira hacia el interior de Cuba. Son varios los motivos que posibilitan esta localización política y discursiva. En primer lugar, su origen, pues según versiones de la historia, su ancestro, Pedro Pavón del Monte Pichardo, llegó a América en el segundo viaje de Cristóbal Colón. Establecido en Santo Domingo, está su nombre entre los fundadores de la villa de Santiago de los Caballeros. Por tal razón, los Del Monte podían alegar que constituían una de las primeras familias americanas de origen español, también una de las que formaron la oligarquía regional criolla de los siglos diecisiete y dieciocho. La genealogía registra que hasta llegar a Domingo del Monte, sus antecesores fueron

\footnotetext{
${ }^{23}$ Algunos de los poetas que se vincularon con del Monte fueron: Ramón de Palma (1812-1860), Juan Francisco Manzano (1797-1854), Gabriel de la Concepción Valdés Plácido (1809-1844), José Jacinto Milanés (1814-1863), Ramón Vélez Herrera (1808-1886), Gaspar Cisneros Betancourt (1803-1866), Juan Francisco Pobeda y Armenteros (1796-1881), Gertrudis Gómez de Avellaneda (1814-1873) y José Fornaris (1827-1890), entre otros.
}

\footnotetext{
${ }^{24}$ Uno de los intentos concretos por lograr la independencia es el que lleva adelante la logia secreta de criollos denominada los "Soles y Rayos de Bolívar", uno de sus líderes fue el escritor José María Heredia. La conspiración para derrocar al gobierno español llevada adelante en 1823 finalmente fracasa. Antes, en 1812, había fracasado la conspiración llevada adelante por el mulato José Antonio Aponte. Como consecuencia de la revuelta, es asesinado y a manera de advertencia su cabeza es colgada en la plaza. La revista digital La Jiribilla ha publicado un interesante dossier en el cual se recupera la imagen de este liberto que lideró una conspiración abolicionista histórica. Ver La Jiribilla X.571 (2012).
} 
cultivando fama en las armas, prestigio social, poder político y riquezas. Tanto que la familia de Del Monte es parte de ese tradicional patriciado local de Santiago de los Caballeros que dio origen al arraigado Criollismo que se expresaba en el amor y la defensa de la "patria local" y en un "sentimiento americanista e hispánico" (Andioc Torres 2002).

En segundo lugar, se suman a ese linaje patricio los vínculos familiares, económicos y políticos que lo ligan al poderoso grupo azucarero Alfonso-Aldama ${ }^{25}$, pues en 1834 Domingo del Monte contrae matrimonio con Rosa Aldama y Alfonso. En tercer lugar, hay que tener en cuenta la pertenencia política e ideológica de Domingo del Monte. Para la crítica, los intereses partidarios de Del Monte se relacionan con las facciones tempranas del reformismo liberal ilustrado.

Al respecto, cabe destacar que en la primera mitad del siglo diecinueve se advierten distintos movimientos que expresan el sentimiento cubano frente a la dominación española y cuyas propuestas han sido plasmadas en diversos programas constitucionales. Los grupos emergentes son los "autonomistas", los "reformistas", los "separatistas", que se desglosan en "anexionistas" (partidarios de obtener la ayuda de otro país, principalmente Estados Unidos, para lograr la separación de Cuba de España) y los "independentistas" (cuya finalidad era la organización de un gobierno soberano e independiente) y, en oposición a ellos, se registra el grupo de los "integristas", constituido por los españoles partidarios de mantener los privilegios económicos, políticos y sociales de los nacidos en la península. El primero que aparece en escena es el autonomismo, que solicitaba un régimen autonómico para la isla de Cuba. Sus principales manifestaciones constitucionales, legislativas y doctrinales fueron los escritos de José Arango y Parreño (1765-1837) y los proyectos constitucionales de Jesús Agustín Caballero (1762-1832), Claudio Gabriel de Zequeira y Félix Varela

\footnotetext{
${ }^{25}$ Uno de los más poderosos clanes familiares es precisamente el constituido por el grupo AlfonsoAldama- Madam. En 1836, los Alfonso figuran en el lugar treinta y seis entre las grandes fortunas de Cuba, los Aldama en el duodécimo y los Madam en el quinto. A inicios de la década del sesenta poseían cuarenta ingenios azucareros y quince mil esclavos y almacenes, ferrocarriles, seguros marítimos, casas de crédito, bancos y líneas de vapores. Además poseían títulos nobiliarios y estrechas relaciones con los Borbones de Francia (Moreno Fraginals 1978).
} 
(1788-1853) filósofo del cual Del Monte fue discípulo ${ }^{26}$. Estos proyectos propugnaban, en líneas generales, el cese del proteccionismo económico, la libre concurrencia y la creación de instituciones insulares con amplia competencia en materia de hacienda, comercio y seguridad pública. El autonomismo se consolida como partido político finalizada la Guerra de los Diez Años (1868-1878) con la creación del Partido Liberal Autonomista (PLA) en 1881, pero las causas de su constitución son distintas y se relacionan con el contexto de emergencia. El grupo autónomo de la primera mitad del siglo diecinueve responde a causas pragmáticas e ideológicas, entre las cuales se destacan la consolidación de la industria azucarera en Cuba como resultado de la caída de otros mercados del Caribe, lo que promovió el poder de sector terrateniente y la convicción de la elite oligárquica de que podía hacerse cargo de la conducción política y económica de la isla.

El grupo de los reformistas se establece a mediados del siglo diecinueve, cuando se crea el Círculo Reformista que aglutinaba a miembros de la oligarquía junto a una minoría ilustrada. Del grupo se destacan las figuras del ya mencionado José Antonio Saco y Enrique José Varona (1849-1933). En el "Programa" del Círculo (elevado en 1867) quedaron expresadas las demandas del grupo. Éstas eran: 1) igualdad de derechos políticos para cubanos y españoles; 2) representación cubana ante las cortes metropolitanas; 3) Ley de imprenta igual a la de la península; 4) prohibición de la trata de negros y de toda inmigración de color; 5) fomento de la inmigración blanca; 6) resolución del problema de la esclavitud en conciliación de los intereses de los propietarios; 7) extensión a Cuba de las leyes civiles, penales y mercantiles de la península; 8) elaboración de leyes municipales semejantes a las de la península y 9) sistema de control de los funcionarios peninsulares.

\footnotetext{
${ }^{26}$ La crítica ha profundizado en el legado filosófico de Agustín Caballero y de Félix Varela al considerar la impronta que sus reflexiones dejaron en la formación de una generación singular de seminaristas del colegio San Carlos, entre ellos, Domingo del Monte. Salvador Bueno (1979) en La crítica cubana literaria del siglo XIX señala que: "La labor desarrollada por el padre José Agustín Caballero tuvo un carácter progresista en aquella sociedad colonial enquistada en el escolasticismo y las más estrechas reglas ortodoxas religiosas. El profesor del Seminario de San Carlos, como sus contemporáneos Arango y Parreño, Romay y otros, respondía a la situación cubana de su época, al surgimiento de una nueva clase criolla que se enfrentaba a las normas provenientes de España, chocaba con los comerciantes peninsulares y necesitaba de una opción reformista que le permitiera ascender económicamente. El padre Caballero comenzaba la reforma que completaría su discípulo y amigo Félix Varela” (25).
} 
En cuanto al grupo separatista, éste surge a principios del siglo diecinueve, motivado por las gestas independentistas llevadas a cabo en el continente americano. $\mathrm{Su}$ propuesta general era lograr la separación de Cuba de España. Esta intención se expresó en dos posturas, la de los anexionistas y la de los que pugnaban por una república independiente (Bernal Gómez 1997; García Mora 2001; Aguilera-Manzano 2007).

Como hemos referido con anterioridad, la sacarocracia ilustrada cubana proyecta un determinado ideario patriótico en función de sus intereses políticos y económicos. No son partidarios de una separación porque eso conllevaría una revolución $\mathrm{y}$, por ende, la ruina. Tampoco son partidarios de la anexión, pues consideran que fundir a Cuba en el coloso del Norte conllevaría a una pérdida de identidad. Para los dirigentes de esta clase, solo es posible pensar en una reforma lenta que conduzca con el paso del tiempo a un desprendimiento de la Corona española. Del mismo modo paulatino debe abandonarse la esclavitud como institución, por lo que promoverán el cese del comercio negrero, pero sin declarar la abolición de la trata y, al mismo tiempo, propondrán el blanqueamiento de la población para evitar una rebelión peligrosa como la de Haití.

\subsection{Poder blanco, cuerpos negros: retóricas del mestizaje en el discurso patriótico}

De los aspectos que fracturan y convulsionan la sociedad cubana en el siglo diecinueve, es el criterio racial, el "problema negro", el que se advierte en este período como el principal factor de segmentación. Al respecto, los discursos sobre la identidad cubana elaboran una serie de imágenes tendientes a superar las distancias raciales "de sangre". En este sentido, serán los letrados cubanos agrupados bajo las facciones autonomistas y reformitas del liberalismo quienes impulsen la fórmula "patria igual a libertad" y se ocupen de trazar soluciones que subsuman las diferencias raciales en una "única nación de ciudadanos" y proyecten un escenario social en el cual la civilidad sea posible (Quijada 2003; Guerra 2003).

De acuerdo con los principios que sustenta el reformismo ilustrado, la literatura se constituye en potencia como un discurso desde el cual es posible "reformar" la sociedad. Este papel pedagógico y moral atribuido a la literatura favorece un tipo de 
expresión literaria signada por el tono crítico y sancionador y por la preeminencia de la descripción.

En correspondencia, el grupo de Saco y Del Monte crea todo un cuerpo discursivo constituido por ensayos políticos, económicos y científicos más la propuesta literaria y educativa para delimitar un proyecto de nación autónoma. Estos “dispositivos", creadores de significado, están orientados hacia el "pueblo", entendido como una masa heterogénea y conflictiva a la que es necesario "homogeneizar". Estas intenciones, que albergan contradicciones, manifiestan un proceso de organización de lo social puesto en marcha, un proceso dinámico y complejo que implica instancias de proyección y fijación de sentidos y prácticas culturales a los efectos de construir una idea de patria. El cuerpo discursivo funciona, entonces, como un cuenco de valores y significados con los que esta elite criolla delimita una idea de patria que luego conformará un diseño de nación.

Como ya hemos señalado, es la modernización ligada a la industria azucarera la que permite que Cuba entre en contacto con corrientes de pensamiento de corte liberal, provenientes de otros países aparte de España. En este sentido, la promoción del tráfico ferroviario y fluvial permitió no sólo el despacho de los productos hacia los puertos sino que facilitó las comunicaciones de una región a otra.

Como expresa Gaspar Betancourt Cisneros (1803-1866) en una carta escrita a Domingo del Monte $^{27}$, fechada el 20 de Octubre de 1836: "Dicen que hay noticias gordas y buenas de allende los mares, pero que no conviene que corran. Lo malo es que en estos malditos tiempos de imprenta, vapores, ferrocarriles, vuela el pensamiento y hasta lo que no se piensa vuela también" (2002: 61).

La sociedad cubana de finales del siglo XVIII y comienzos del siglo diecinueve era ya una sociedad cosmopolita y dinámica. De esto deja constancia Alexander von Humboldt (1769-1859) quien, en 1826, data en su Ensayo politico sobre la isla de Cuba:

El trato de la gran sociedad de La Habana se parece por sus maneras atentas y su urbanidad al de Cádiz y al de las ciudades más ricas de Europa. (...). La

\footnotetext{
${ }^{27}$ Todas las citas del epistolario de Domingo Del Monte pertenecen al Centón epistolario. 1836-1840. Volumen 2.
} 
Habana parecía diez veces más cercana a la España que Méjico, Caracas y Nueva Granada (1960: 202).

A partir del boom azucarero, Cuba se volvió técnicamente más moderna que España, prueba de ello es que el primer buque a vapor en América Latina fue adquirido por Cuba en 1819 y el primer ferrocarril fue inaugurado en 1837, antes que en la propia metrópoli.

Los letrados que conforman la sacarocracia y la clase media criolla entran en contacto con las ideas de la Ilustración, a partir de las cuales se sustenta la convicción de que la historia se suma en el doble infinito del pasado y del futuro, promoviendo el discurso del progreso y del optimismo histórico. A esta concepción "progresista" de la historia se la vincula con la noción de "civilización", homologada a la de "cultura". En este sentido, es necesario advertir como cambio trascendental la división de "saberes" devenida del discurso histórico, con la ciencia llamada "etnología", según el término creado por Alexandre de Chavannes (1731-1800) en 1787, que la define como la disciplina que estudia "la historia de los progresos de los pueblos hacia la civilización" (Foucault 1997).

Esta concepción desacralizada de la historia, sumada a la representación unilineal del devenir histórico, derivó en el supuesto de que las sociedades no europeas se situaban detrás, es decir, en estado de "menos civilización”, es por eso que, aunque Cuba sea "técnicamente más moderna", desde la mirada europea, la Modernidad concebida desde parámetros eurocéntricos, no ha sido aún alcanzada. Como señala Grüner, las pretensiones "universalistas" de una modernidad "revolucionaria" que había declarado los Derechos Universales del Hombre y del Ciudadano había puesto un límite particular a esa "universalidad", que tenía asimismo un color particular: el color negro. Se trata, en consecuencia, de una modernidad que no es un bloque homogéneo, simétrico y armónico: está dividida contra sí misma, pues el Particular no es un caso del Universal sino que está en conflicto irresoluble con él, es una excepción en la imagen de la Totalidad ${ }^{28}$. Para Grüner, la colonialidad del saber no fue capaz de anticipar la Revolución haitiana pues,

\footnotetext{
${ }^{28}$ Se reproduce en este apartado el uso de las comillas, las itálicas y las mayúsculas que presenta el texto original de Eduardo Grüner.
} 
¿cómo podía siquiera concebir que fueran [los negros] capaces no solo de hacer una revolución, sino que esa revolución viniera a señalar, como quien mete el dedo en una llaga, la incompletud culpable de ese orgullo "universal" llamado Modernidad?

El silencio estruendoso del pensamiento eurocéntrico sobre la Revolución haitiana no es —aunque pueda serlo también- un mero ocultamiento intencional: ese silencio está ya inscripto desde antes de producirse la revolución, en la impensabilidad, para los europeos, de su ocurrencia. (...) La Revolución haitiana viene a poner en crisis de facto, simultáneamente, a dos componentes centrales de la colonialidad del saber: tanto al pensamiento eurocéntrico — aún el más filosóficamente sofisticadocomo a la concepción evolucionista, lineal y "progresista" de la historia, imposibilitada de reconocer un desarrollo desigual y combinado de las historias de las sociedades, que en momentos de crisis hace estallar todas las linealidades históricas en un instante —ahora catastrófico (2010: 47).

En el camino hacia las luces y la civilización, la esclavitud se presenta como un obstáculo o, siguiendo a Grüner, como la contracara de la Modernidad, "aquello que expone un exceso irreconducible al Universal, un resto que desde la resistencia de lo real pone límites infranqueables a lo que quisiera ser la trama cerrada y unívoca del imaginario acabado de la Modernidad" (2010: 45). En consecuencia, la Revolución haitiana modificó la percepción de la esclavitud. En el caso de Cuba, los propietarios de los esclavos temían una sublevación similar a la ocurrida en Haití (Duno Gottberg 2003; Ferrer 2003; Leclercq 2004; Mintz y Price [1976] 2012). El temor se instaló además por las advertencias que realizara en sus escritos Alexander von Humboldt, quien proponía como medida la abolición de la esclavitud. En el capítulo VII de su Ensayo político sobre la isla de Cuba sostiene:

Las grandes revoluciones que el continente americano y el archipiélago de las Antillas han experimentado desde principios del siglo XIX han influido en las ideas y en la razón pública del país mismo en que existe la esclavitud y empieza a modificarse (...) se puede por medio de un acuerdo libre entre los propietarios y, por medio de medidas que dimanen de los que conocen sus localidades, salir de un estado de crisis y de perplejidad, cuyos peligros se 
aumentarán con la indolencia y la obstinación. (...) La esclavitud es, sin duda, el mayor de todos los males que han afligido a la humanidad... (1960: 283).

El auge del discurso abolicionista en Cuba hacia 1840 encuentra parte de su fundamento en este estudio "minucioso" que consta de "citas sacadas de documentos oficiales". En este marco, en la formación de un discurso del mestizaje no se propondrá una revalorización del negro y su cultura sino más bien el intento por incorporar a dicha población a una totalidad que trata de imponer diversos grados de aculturación. Como enfatiza Julio Ramos:

Producidos poco después de la revolución en Haití, los discursos sobre la heterogeneidad etno-lingüística en Cuba, en tanto enigma que debe ser resuelto, develado, en el proceso de configuración nacional, nos hablan más bien sobre las fobias de la propia elite liberal, aún tímidamente modernizadora, que articula las representaciones de los esclavos. En esas representaciones la élite liberal elabora, especularmente, sus categorías de identidad, de raza, de lengua, de ciudadanía, acaso sin llegar a dominar nunca su propia ansiedad ante la ineluctable heterogeneidad étnica que, por otro lado, motiva y paradójicamente estimula la producción de discursos de orden y condensación (1996: 24).

Estos discursos de orden y de condensación encuentran en el ingenio un núcleo configurador por excelencia: el ingenio modifica el paisaje físico y social de Cuba. Con él llegan los grandes adelantos modernizadores, se produce el ingreso masivo de esclavos y grupos sociales ligados a la industria adquieren un poder inusitado, otros pierden su nivel de representación e influencia. La relevancia del azúcar como emblema de Cuba habrá de ser notada, analizada y perpetuada casi cien años después del período que nos ocupa por Fernando Ortiz en su obra Contrapunteo cubano del tabaco y del azúcar (1946), allí define el lugar del azúcar en esta encrucijada al sostener que "desde el mismo origen de la producción sacarífera, en el siglo XVI toda la historia de Cuba se entreteje alrededor de la foránea dominación azucarera, la cual siempre ha exigido el predominio de sus intereses lucrativos y lejanos sobre los nacionales del país (1999: 53).

Hacia el tercer decenio del siglo diecinueve, la heterogeneidad expresa la realidad cubana y tal como han señalado algunos críticos, la tensión "nación” vs. 
“ingenio" se instala como polémica en los debates epocales y da cuenta no sólo de los enfrentamientos políticos y económicos entre los nuevos grupos sociales y étnicos que caracterizan a Cuba en este período de desarrollo industrial, sino de los intereses que orientan y posiblemente delimitan el perfil de la patria cubana. En este sentido, serán los letrados vinculados tanto al sector tradicionalista como aquellos cuyas ideas se orienten hacia el liberalismo, quienes proyecten un imaginario simbólico respecto de lo que significa la identidad colectiva nacional. Mediante procesos de inclusión y exclusión, evaluarán la significatividad positiva o negativa de determinados elementos sociales, étnicos, culturales, geográficos, históricos, incorporando al perfil patriótico aquellos que resultasen más convenientes y definidores de la "cubanidad".

En 1834, las reflexiones de Francisco de Arango y Parreño dan cuenta del viraje en la percepción del trabajo esclavo por parte de la sacarocracia cubana, adoptando el discurso del mestizaje como eje de la solución a la "peligrosa heterogeneidad" (González Ripoll 2010). En un texto suyo titulado "Borrar o destruir la preocupación por el color" en Representación al rey sobre la extinción del tráfico de negros y medios para mejorar la suerte de los esclavos coloniales de 1834, propone la liberación de los esclavos, sin que se pierda la dominación sobre éstos como la superación del prejuicio social. En 1845, se cristaliza la posición de José Antonio Saco en su informe "La supresión del tráfico de esclavos africanos en la isla de Cuba, examinada con relación a la agricultura y su seguridad".

La elite cubana no se decidió por la Independencia para defender sus intereses económicos, pues cualquier insurrección amenazaba la institución de la esclavitud y mutilaba la revolución agrícola que era la base económica del país y la fuente de su riqueza. El aplazamiento de la Independencia, ocasionado por el tardío desarrollo de la plantación, corre paralelo con el aplazamiento del abolicionismo, explicado por razones de índole económica y paralelamente por argumentaciones raciales. Este aplazamiento de la abolición ahonda la drástica división social entre blancos y negros. En esta coyuntura, la identidad social cubana es concebida únicamente blanca: los negros no son cubanos, son esclavos.

En páginas precedentes hemos señalado las contradicciones del discurso de la elite ilustrada frente al sistema de la esclavitud, pues si bien sobre éste se deposita la 
mano de obra para la producción del azúcar, fuente de riqueza y poder, al mismo tiempo, esta élite adopta el pensamiento liberal y asimila la práctica esclavista con la barbarie y el atraso de la civilización. No obstante, dos discursos fueron puestos en escena por los letrados reformistas: la retórica del blanqueamiento y, de modo paradójico, la defensa de la esclavitud como sistema que posibilitaba la civilización de los "salvajes" africanos.

Ambos discursos articularon sus argumentos sobre los principios del Positivismo y las teorías racionalista-biologicistas. A partir de mediados del siglo diecinueve, nuevos avances de las antiguas ciencias europeas como la ontología, la zoología y la anatomía comparada se sumaron a los aportes de las ciencias en ciernes como la frenología, la psicología experimental, la psicología de multitudes para “justificar científicamente” la inferioridad mental del negro haciendo del africano el nuevo y más crudo representante de la barbarie. La idea de la desigualdad de las razas y la opinión prevaleciente del estatuto racial inferior del africano vehiculizadas, entre otros, por Joseph Arthur de Gobineau ${ }^{29}$ sirvieron para seguir argumentando en favor de la esclavitud de seres inferiores y de la misión civilizadora de los blancos frente a los ataques de los abolicionistas europeos y $\operatorname{cubanos}^{30}$.

${ }^{29} \mathrm{Al}$ respecto, cabe señalar que la retórica mixófoba se pronuncia sobre dos temas: la impureza y la inferioridad del mestizo. La tesis desigualitaria del diplomático francés Joseph Arthur de Gobineau (1816-1882) contribuyó ampliamente a la divulgación de la idea de una jerarquía "natural" de las razas, del mito de superioridad de la raza aria o nórdica. No obstante, Gobineau no fue el inventor de la superioridad de la raza blanca, ni de privilegio de los arios ni de la mixofobia, su propia tesis (publicada en 1853 en el ensayo Essai sur l'inégalite des races) es una mezcla de todas las teorías sobre el mestizaje publicadas con anterioridad. Luego, en 1894 se sumarían los argumentos de Gustave Le Bon para presentar al mestizaje como un defecto genético, una ruptura del orden biológico que conduce incluso a la desaparición de la humanidad, a la extinción tanto de blancos como de los negros. Aunque la tesis gobiniana tuvo poca resonancia en Europa, si tuvo un impacto muy importante en América Latina, donde la admiración por el poder de la técnica y la expansión industrial y política llevó gradualmente a la aceptación de las teorías evolucionistas, sociales y raciales, cuyas repercusiones eran imprevistas. Sobre el mito de superioridad nórdica ver W. Stewart y James A. Glynn (1977) "El surgimiento del mito nórdico". De la bibliografía disponible nos parece muy útil para comprender la formación de Fernando Ortiz en la Escuela Positivista italiana el trabajo de Puig-Samper, Miguel Ángel y Naranjo Orovio, Consuelo (1999) "Fernando Ortiz: herencias culturales y forja de la nacionalidad". Por otro lado, ha sido sumamente valioso para comprender el pensamiento de Fernando Ortiz y su impronta en los estudios antropológicos latinoamericanos, el seminario "Intelectuales y cultura popular en el pensamiento latinoamericano (Argentina, Cuba y Brasil, 1930-1960)" dictado por la Dra. Alejandra Mailhe en el cual hemos revisado la figura de Fernando Ortiz a partir de considerar su locación y (dis)locación en el campo de la antropología cultural cubana y latinoamericana.

${ }^{30}$ Como señala Eduardo Grüner (2010), a propósito de un ensayo que María Eugenia Cháves publica en 2007, el pensamiento sobre la raza, las clasificaciones raciales y la exclusión racial no se generaron 
Como consecuencia de la adopción de todo un marco pseudocientífico que postulaba la inferioridad del africano, el color negro se vuelve un signo de ignominia, y se establece que la esclavitud no es un hecho social sino natural.

De la mano de esta concepción, se establece el mito de la superioridad racial de los blancos. La repercusión que tuvo la importación masiva de esclavos y de la exportación de azúcar implicó mucho más que un impacto proporcional en la población y en la economía. La oposición a la esclavitud crecía tanto dentro como fuera de la isla. El temor frente a una sublevación como había ocurrido en Haití era omnipresente, y los letrados reformistas que no adherían a la abolición por intereses económicos consideraba a la esclavitud como un mal necesario. Frente a la africanización masiva, los criollos adoptaron una actitud francamente racista en favor de una Cuba blanca. Pero en los años entre 1830 y 1850 esta actitud no era ni verosímil ni factible. A pesar de que Cuba tenía mayor proporción de blancos en su población que cualquier otra isla caribeña productora de azúcar, no estaba en condiciones de abastecer por sí misma la mano de obra requerida en los ingenios según la demanda internacional. La desproporción entre blancos y negros era hacia 1840 del $60 \%$ de negros contra un 40\% de blancos.

Para contrarrestar la africanización y la posible haitianización de Cuba, una parte de la sociedad criolla se encargó de favorecer la inmigración blanca, bajo el auspicio de la Sociedad Económica y del Consulado de La Habana. En tanto que España promulgó un conjunto de leyes que respondían al intento de blanqueamiento. El gobierno ofreció toda una serie de ventajas a los colonos blancos que se establecieran en Cuba.

Domingo del Monte, José Antonio Saco, Gaspar Betancourt Cisneros fueron algunos de los letrados que alentaban la inmigración blanca para contrarrestar las estadísticas de la población negra. Por ejemplo, Juan Antonio Saco promueve la inmigración de colonos canarios en su artículo La supresión del tráfico de esclavos africanos en la Isla de Cuba, examinada con relación a su agricultura y a su

recién a fines del siglo dieciocho sino que tiene un espesor histórico que se remonta al Renacimiento español y al conjunto de discursos que surgen a partir de la exploración y conquista de América y África. 
seguridad (1845). Sin embargo, el problema de la colonización blanca era doble, por un lado, el proceso de industrialización absorbía gran parte de la mano de obra europea blanca, mientras que otra parte emigraba a América del Norte. Por otro lado, la colonización blanca europea ponía en riesgo al sector criollo español. En este sentido, el propio Del Monte se opone en 1846 a un plan de colonización que perseguía la inmigración de alemanes y escoceses argumentando que no podrían adaptarse al clima. El Criollismo de Del Monte apuntaba a guardar el carácter exclusivo y genuino del criollo español y a no caer en una heterogeneidad blanca.

De lo expuesto en párrafos anteriores se deriva que en el interior de los grupos criollos había oposiciones, tensiones y desencuentros que ponían de manifiesto diferentes actitudes frente a la esclavitud. El caso de Del Monte es particularmente significativo. Para él, el desprecio por la esclavitud residía en una meta concreta, de carácter filantrópico: su aspiración de que Cuba se convierta en un foco de civilización europeo en el mundo occidental. Es por ello que bajo su concepción, la cubanidad implicaba la exclusión absoluta de los negros. Sin embargo, sus esfuerzos de preservar la identidad social de Cuba de toda negrura fueron en vano: los negreros y los sacarócratas cubanos más acérrimos lo hicieron expatriar al igual que a J. A Saco ${ }^{31}$.

Saco representaba a una clase social seriamente amenazada económicamente e incluso desplazada geográficamente hacia el Oriente — donde tenía sus tierras la antigua oligarquía criolla ganadera y tabacalera - por la sacarocracia que mayoritariamente demostraba admiración hacia EE.UU, menosprecio hacia los valores hispánicos y sentimientos anexionistas.

Si bien Saco consideraba como Del Monte que la nacionalidad de Cuba solo podía ser formada por la raza blanca, en sus artículos asumió una postura política mucho más clara que la ambigua posición de Del Monte. Saco propuso una doble campaña de blanqueamiento, pronunciándose a favor de la inmigración blanca de cualquier país y oponiéndose abiertamente a la trata ilícita. La estrategia antianexionista y reformista de Saco articula un discurso sobre la nacionalidad que se

\footnotetext{
${ }^{31}$ La mayoría de los sacarócratas que defendían la esclavitud se inclinaron por las ideas anexionistas, pues veían en la anexión a EE.UU un país que sostenía la esclavitud. Para la crítica, es insoslayable el vínculo entre anexionistas y la defensa de la esclavitud.
} 
opone vigorosamente a la Independencia, por considerar que la escasa población blanca cubana estaba amenazada tanto por una eventual haitianización como por una involuntaria anexión de ésta a los EE.UU. En este sentido, Saco fue el primero en advertir y prevenir sobre la intervención estadounidense. $\mathrm{Su}$ idea de nacionalidad corresponde a un momento histórico preciso, cuando la tensión entre la sacarocracia y la burguesía está agudizándose, es decir, cuando el pensamiento anexionista chocó con el pensamiento reformista. En consecuencia, en 1834, fue expatriado por el gobierno colonial bajo la presión de los hacendados azucareros cubanos y de los negreros españoles ligados al poder.

Según Duno Gottberg, las estrategias discursivas que persiguen la conciliación de conflictos raciales en la sociedad cubana en el siglo diecinueve se han expresado en una serie de metáforas y conceptos sobre la identidad nacional o protonacional que se inscriben de un modo más general en lo que él considera "una tradición de la ideología del mestizaje" (2003: 15). Con esta premisa hace alusión a la invención de un discurso que a lo largo de la historia pretende fijar una imagen uniforme y sólida del sujeto latinoamericano. El autor advierte una serie de instantes fundamentales en el desarrollo histórico del pensamiento cubano, el cual responde repetidamente a los conflictos raciales proponiendo discursos que, en última instancia, intentan desdibujar las diferencias étnicas, creando la imagen tranquilizadora de una nueva identidad cohesiva. Estás metáforas son "la patria mestiza", "la patria sin color", "la cubanía”, "el ajiaco", “el cóctel”, “el barroquismo" (16).

Estos usos metafóricos son articulados por los letrados quienes imaginan y prescriben un ideal de lo cubano, produciendo discursos que pretenden solventar (término elegido por el Duno Gottberg para expresar el sentido de "resolver problemas difíciles o hacerlos menos visibles") las diferencias que a sus ojos obstaculizan la formación nacional.

Uno de esos "instantes fundantes" lo constituyen, para Duno Gottberg, las propuestas de Domingo del Monte y su grupo. En especial, este crítico recupera - a partir del análisis de la obra de José Antonio Saco- el proyecto de colonización blanca que éste último impulsaba para terminar con la trata negrera: todo un programa explícito de reformas sanitarias, jurídicas e impositivas de la sociedad colonial cubana 
que tenían como fin un principio de "abolicionismo con esclavitud (para proteger los intereses de la colonia) y reformismo sin independencia" (2003: 40). Para lo cual Saco redactó numerosos ensayos entre los que se destacan Historia de la esclavitud de la raza africana en el nuevo mundo en los países américo-hispanos (1837-1875) у "Carta a un patriota (1835)"32 en los cuales se ocupa mediante el estudio analítico de rebatir las hipótesis sobre las cuales se fundamentaba la opinión de la sacarocracia cubana: 1) que el tipo de trabajo realizado en los ingenios eran tan duro que solo lo podían resistir los esclavos africanos, 2) que solo los esclavos africanos podían adaptarse al clima en Cuba y 3) que pagar jornales era muy costoso. A lo que Saco responde que "el hombre negro rechaza el trabajo pues éste se relaciona con la civilización y que la impericia y el sabotaje del esclavo resultaban mucho más onerosos que el pago de salarios" ${ }^{\text {”3 }}$. El proyecto de colonización impulsado por Saco pretende redefinir lo cubano mediante un proceso de "blanqueamiento": impuestos, educación, seguridad jurídica, salud y condiciones climáticas debían ser repensadas en función de una colonización blanca ${ }^{34}$.

En síntesis, este programa para solventar los conflictos generados por la presencia del esclavo africano se va constituyendo a través de múltiples textos, articulando no solo las necesidades económicas y políticas, sino también las psíquicas: el miedo al negro impulsa a Saco a prever escenarios de rebelión y destrucción que van más allá de Cuba. En efecto, la "Carta de un patriota" es acompañada de una reseña de un libro sobre el Brasil que escribe un autor inglés ${ }^{35}$.

\footnotetext{
32 "Carta de un patriota, o sea, clamor de los cubanos dirigidos a sus procuradores a cortes: Comercio de negros" (1835). Como sostiene Eduardo Torres Cueva en la Introducción de la Historia de la Esclavitud, 38 años le llevó a José Antonio Saco escribir esta monumental obra, que por razones muy diversas ha sido poco estudiada.

${ }^{33}$ En el artículo "La supresión del tráfico de esclavos africanos en la isla de Cuba, examinada con relación a su agricultura y a su seguridad" se explicita esta postura.

${ }^{34}$ En unos de los apartados del artículo: "Réplica de Don José Antonio Saco a la contestación del señor fiscal de la real hacienda de La Habana, Don Vicente Vázquez Queipo en el examen sobre el fomento de la población blanca, etc., en la isla de Cuba" se detalla "Puntos esenciales de mi carta sobre los cuales guarda el señor Queipo guarda el más profundo silencio". Entre esos puntos Saco indica el plan de colonización blanca.

${ }^{35}$ Esta reseña se publica en la Revista Bimestre, cuyo análisis abordaremos en el capítulo II. También disponible en una versión completa de este artículo en el Volumen II de las Obras de J.A Saco.
} 
Los temores frente al sujeto negro elaboran todo un imaginario del terror frente al Otro que habita los márgenes de la patria, y décadas más tarde, de la nación: monstruoso, acechante, amenazante, pues “el negro que sirve y amenaza está en la plantación, en el ingenio, en el taller y en la cocina" (2003: 42).

Para Duno Gottberg, solventar la trata de esclavos es en este "instante fundamental" y agregamos, fundacional, disolver la presencia africana, es borrar un elemento "disonante y peligroso" en el seno de la patria. No responde exclusivamente al deseo de estimular la colonización con hombres libres debido a las necesidades de producción de la industria azucarera; responde también al proyecto de controlar la presencia de un elemento étnico que amenaza cierta concepción de lo cubano ${ }^{36}$.

Al respecto en una carta fechada hacia 1845 , Saco se pronuncia con relación a este problema proponiendo el mestizaje como solución a la persistencia de elementos étnicos "indeseables" dentro de la isla:

El gran mal de la isla de Cuba consiste en la inmovilidad de la raza negra que conservando siempre su color y origen primitivo se mantiene separada de la blanca por una barrera impenetrable; pero póngasela en movimiento y entonces crúcesela con otra raza (...). Si los mestizos naciesen de enlace blanca y negro, esto sería de sentirse mucho, porque menguada nuestra población blanca, la debilitaría en todos sus sentidos, pero como sucede todo lo contrario, yo lejos de mirarlo como un peligro lo considero como un bien ${ }^{37}$.

La postura respecto de la abolición y el borramiento de lo negro en el grupo reformista que tiene a Del Monte y a Saco como protagonistas (al menos por la difusión y trascendencia dentro y fuera de la isla que tienen sus escritos) está saturada de matices que exponen tensiones y contradicciones. De los intereses filántropos del propio Domingo del Monte, quien en 1834, recibirá en su tertulia al esclavo Juan Francisco Manzano, gesto con el que hace visible un lugar para el negro/esclavo/aprendiz en el seno de las letras cubanas al proyecto colonizador de José Antonio Saco que, primero,

\footnotetext{
${ }^{36}$ Referencias explícitas a este temor se pronuncian en la Segunda Parte del artículo "La supresión del tráfico de esclavos africanos en la isla de Cuba, examinada con relación a su agricultura y a su seguridad" que titula "La seguridad de Cuba clama urgentísimamente por la pronta abolición del tráfico de esclavos" (1845: 116-132).

${ }^{37}$ Epistolario completo en Saco, José Antonio, Obras, Volumen V.
} 
con una de política de blanqueamiento y luego de mestizaje a partir de la explotación de vientres negros por parte de blancos propondrá soluciones a lo que constituyó "la pesadilla de su vida": la situación del negro en $\mathrm{Cuba}^{38}$.

En los apartados que continúan abordaremos los procesos de invención de la patria a partir de considerar los usos metafóricos que sirvieron como matriz simbólica de la identidad cubana en este período.

\subsection{La pluma que imagina la nación: hacia la invención de la patria}

En el contexto antes destacado se señaló que es la elite ilustrada reformista la que instala la necesidad de crear un "nosotros colectivo" que otorgue una identidad homogénea y común a todo el territorio de Cuba, y que permita suturar las diferencias etnolingüísticas y culturales que obstaculizaban el progreso.

Un conjunto de mitos, pautas y símbolos enraizados en elementos preexistentes son los que esta elite buscó redefinir, canalizar, generalizar y sobre todo, “esencializar", tejiendo con ellos las redes de la identificación colectiva. Estos hombres modernos, auténticos "nation-builders", en el término que emplea Mónica Quijada para referirse a las élites hispanoamericanas conformadas por ensayistas, literatos e historiadores, imaginaron la nación que querían y aplicaron a esa imaginación sus posibilidades de acción pública. Pero, si la nación fue el producto de una creación histórica moderna, lo que le dio fuerza y continuidad fue la esfumación en el imaginario colectivo de su carácter de invención en el tiempo (Anderson 1993; O'Gorman [1958]1995).

Ahora bien, dos conceptos han entrado en juego y es preciso discriminarlos, porque implican procesos de configuración diferentes: el concepto de "patria" y el concepto de "nación". Es válido advertir que en los últimos años se han multiplicado los trabajos historiográficos que dan cuenta del desarrollo histórico de tales nociones en el marco de los estudios sobre Historia de las ideas, Historias de los intelectuales o

\footnotetext{
${ }^{38}$ Así lo explicita en una carta fechada el 6 de Septiembre de 1878, dirigida a José Valdés Fauli: "Me habla usted de sus inquietudes por la causa negrera. Este ha sido siempre mi pesadilla, pero le confieso que hoy me sobresalta menos que antes. A los negros, jamás por si solos, no los temí mucho. Mis grandes temores provenían del caso que divididos los blancos, los negros se aprovecharan de esta división para hacer un levantamiento general, pero la insurrección de Cuba ha demostrado lo contrario". En el volumen V de las Obras, 237-238.
} 

otros).

No obstante la cuantiosa bibliografía publicada sobre el tema, en esta tesis compartimos la mirada de Mónica Quijada, quien nos señala que los conceptos de "patria”, "nación”, "soberanía" en Hispanoamérica no pueden pensarse sin relación a la Modernidad. Y más aún, inscribimos nuestro enfoque en el grupo de trabajos que considera que es necesario pensar los procesos producidos en el marco de la Modernidad en un espacio compartido "transatlántico", en palabras referidas por Quijada el "espacio euroamericano" 39 . Desde esta perspectiva, se quiere superar una concepción fragmentaria, "nacionalista", que analiza en forma separada los procesos acontecidos en América y en la Península Ibérica, cuando en realidad la Modernidad impactó a ambos lados del Atlántico. Es decir, la "Euroamérica" se define desde esta óptica historiográfica como un espacio "unitario e interactuante" que comparte grandes revoluciones y es afectada de una manera sustancial por la irrupción de la Modernidad $^{40}$.

En este sentido, las definiciones de los conceptos de "patria" y "nación" que orientan nuestro análisis responden a la mirada teórica aportada por el grupo de estudio coordinado por François-Xavier Guerra y Annick Lempérière (1993, 1994, 2003,

\footnotetext{
${ }^{39}$ Mónica Quijada indica que desde los años ochenta del siglo veinte toma cuerpo toda una tendencia historiográfica que tiene por objeto revisar "ese amplio y complejo proceso de cambios que se extiende desde entre el último cuarto del siglo XVIII y el primer tercio del XIX". Los estudios americanistas agrupados bajo este enfoque sostienen una mirada global "euroamericana", no fragmentaria ni nacionalista que se corre de la tradicional concepción respecto de que las independencias americanas eran el resultado del enfrentamiento entre las tendencias modernizadoras de América y el absolutismo tradicionalista español. Ver Quijada 2006.

${ }^{40}$ Para Mónica Quijada, la definición de Modernidad es tan compleja como la de nación. Si bien ha perdurado una definición que ubica a la Modernidad en la segunda mitad del siglo dieciocho, en relación directa con la Ilustración y que ha puesto en lugar central una trilogía compuesta por: ciencia, tecnología y educación, sostiene que hay otra definición que instala el elemento político en el centro del problema y es la que ofrece François-Xavier Guerra según la cual "la modernidad sería la consolidación del principio o imagen de una sociedad contractual o igualitaria, de una nación homogénea, formada por individuos libremente asociados, con un poder salido de ella misma y es sometido en todo momento a la opinión o la voluntad de sus miembros" (Quijada 2006: 23). Desde la perspectiva de Koselleck (1993), recién con los cambios en los espacios públicos y en las mentalidades que acontecieron en el último cuarto del siglo diecinueve es pertinente atribuir la expresión "modernidad" a ese periodo. Para Koselleck, hacia el 1800 estos cambios establecen una concepción de tiempo propio. Es por ello que la Modernidad implica un cambio de temporalización en los conceptos porque se transforma la percepción del pasado (condicionado por la mirada del presente), el presente (que pasa a verse como transición) y el futuro (que se carga de expectativas).
} 
$2004)^{41}$, quienes fueron pioneros en revisar ciertas prácticas discursivas acontecidas en el siglo diecinueve en el espacio euroamericano. Algunos consensos básicos se han podido establecer alrededor de estos conceptos tan resbaladizos y polisémicos. Al respecto, es posible sostener, de manera casi unívoca, que el concepto de "patria" mantiene una connotación estable a lo largo de toda la Edad Moderna y alude a "la tierra en la que se ha nacido" (Covarrubias 1611). Razón por la cual, el término "patria" es el evocado en los discursos independentistas del siglo diecinueve ${ }^{42}$. Dos pautas fundamentales subyacen en esta preferencia: una práctica común y secular de identificación comunitaria y una connotación político-ideológica de acuñación moderna. En cuanto a la primera, es significativo que frente al concepto más ambiguo y cambiante de "nación", el de "patria" tenga una connotación más precisa que liga la identidad a lo telúrico. En la tradición hispánica este concepto significa lealtad filial, localizada y territorializada. En este sentido, la lealtad a la patria, a la tierra donde se ha nacido no es discutible, pues la patria es inmediata y corporizable en el entorno de lo conocido, es por esta razón que, tal como señala Quijada (2003), esta concepción se diferencia de la "comunidad imaginada" que postula Benedict Anderson (1993).

La segunda pauta que subyace en la utilización del término es la identificación creciente, desde finales del siglo dieciocho y como consecuencia de la Revolución francesa, del término "patria" con la idea de libertad. Desde esta perspectiva, las palabras "patria" y "patriota" comenzaron a evocar valores revolucionarios. En el nombre de la patria como sinónimo de libertad, los letrados americanos fueron forjando la ruptura del vínculo político con el gobierno central de la monarquía castellana. Al mismo tiempo, comenzaron a plantear las reivindicaciones que constituyen el fundamento de la nación cívica: leyes comunes e igualitarias, economía unificada, educación común para formas ciudadanos libres e iguales.

Frente a la univocidad del concepto de "patria", el concepto de nación pareciera abarcar, por lo menos, tres acepciones de distinto orden: cultural, territorial e institucional. Correspondiente al primer orden se hallan las definiciones que suponen

\footnotetext{
${ }^{42}$ Al respecto, en un trabajo que ya tiene sus años, pues data de 1978, Luis Monguio ha analizado el uso de los conceptos de "patria" y "nación" en el virreinato del Perú.
} 
que una nación "une gentes en parentesco e idioma"; por inversión, estas definiciones establecen la idea del "Otro". Una segunda definición de nación liga "gentes a un territorio", y por último, se ha desarrollado una tercera acepción de tipo institucional, en la cual el término alude a un "nombre colectivo (comunidad, reino, pueblo, Estado, etc.) sujeto a las leyes y principios institucionales de un mismo gobierno". Cabe advertir que esta tercera dimensión institucional de la nación no aparece como referencia en Hispanoamérica hasta la primera década del siglo diecinueve, cuando impacta y modifica el imaginario político la invasión del territorio peninsular por parte de Napoleón (Quijada 2003: 6).

En consecuencia, a principios del siglo diecinueve, se detecta la vigencia de los términos "patria" y "nación", uno con contenido semántico de tipo tradicional y el segundo, de tipo moderno, impregnado por las ideas ilustradas y la experiencia de la Revolución francesa.

Lo relevante de estas acepciones es su uso discursivo y el alcance programático de su propuesta, intervención que puede observase en los procesos de construcción identitaria particulares que se han producido en Hispanoamérica. Por ejemplo, en el proceso de emancipación, la dimensión institucional del concepto de nación actuó como un elemento organizador fundamental de la voluntad política, instrumentalizado para expresar el afán de los criollos de participar en forma activa en los cambios que produjo la invasión napoleónica. La palabra nación aparece entonces con un sentido institucional específico, a la vez que voluntarista y eventualmente modernizador: la sujeción de la península y América a una misma fuente de poder, la monarquía española, convierte a los habitantes de ambos territorios en una nación y solo con la concurrencia de representantes americanos a la Junta Central se legitimará ésta como un verdadero “cuerpo nacional” (Quijada 2003: 7). Es precisamente esta integración en una nación única la que conlleva a la negación del estatus colonial y a sostener el imaginario de hermandad entre América y España. Sin embargo, según se modifique esta dimensión institucional de la nación, en pos de los procesos revolucionarios coyunturales que se dan a cada lado del Atlántico, esta concepción de "hermandad" sufrirá paulatinos y constantes movimientos que convergerán en un desplazamiento de lealtades de la nación española a la nación americana. Primero, un reclamo activo por 
parte de los americanos — criollos - de participación en el poder. Segundo, la valoración de la corona española como un gobierno "intruso" y el reclamo de la independencia.

Las lecturas de textos liberales alimentan en los letrados del siglo diecinueve el "mito ilustrado del progreso" y permiten formular en una primera instancia la idea de una "nación cívica", esto es, una nación de ciudadanos en la cual se aspira a "borrar" la jerarquización étnica, haciendo hincapié en la fuerza modernizadora y educadora de las instituciones. En correspondencia, opera una estrategia incluyente ante la heterogeneidad, basada en el principio de que las desigualdades no son innatas y pueden modificarse. Por otro lado vale indicar que esta concepción de "nación cívica" sufre un paulatino desplazamiento hacia la idea de "nación civilizada", sustentada por las teorías positivistas y evolucionistas, que excluirá a aquellos que no se adapten al sistema, a los "bárbaros y salvajes". Sujetos "blanqueados" en el color y “europeizados" en la mentalidad y costumbres es, en general, la síntesis del ciudadano deseado para constituir la patria moderna.

En correspondencia, los letrados cubanos realizan una serie de lecturas sobre algunos ensayistas europeos (evolucionistas y positivistas) tales como Auguste Comte (1798-1857), Herbert Spencer (1820-1903) y Jean Baptiste Lamarck (1744-1829) que revelan por un lado, el interés por disminuir el "atraso" insular y promover el progreso $\mathrm{y}$, por otro, el universo de lecturas que circulan entre los letrados y definen la formación de la Ilustración cubana (Leclerq 2004: 254) ${ }^{43}$.

${ }^{43}$ Se ha constatado que Auguste Comte fue uno de los primeros pensadores que tuvo discípulos americanos alrededor de 1850. Incluso, se considera que el cubano José de la Luz y Caballero (como el colombiano Rafael Núñez y el chileno José Victoriano Lastarria, entre otros) se había adelantado a las ideas de Comte, por lo cual es factible sostener una hipótesis de confluencia o de influencia. La entrada del positivismo en Cuba tuvo sus particularidades al igual que en el resto de los países latinoamericanos. La especial condición de país todavía colonizado después de las grandes guerras por la independencia del continente, contribuyó a frenar la introducción de esta filosofía en el ambiente intelectual cubano de mediados del siglo XIX, época en que aún trataba de sobrevivir la escolástica, a pesar de la labor esclarecedora de Félix Varela y el eclecticismo había tratado de infiltrarse, hecho que produjo el enfrentamiento de Luz y Caballero. Algunos consideran las ideas de este pensador cubano, que desarrolla su labor en el segundo tercio del siglo diecinueve, como una de las primeras manifestaciones del positivismo en Cuba, o el tránsito necesario hacia esta corriente, por su defensa del sensualismo y del método experimental. Según Pablo Guadarrama González (2004), "esta afirmación no es plenamente sostenible, pues tanto el sensualismo como el método experimental, así como la preferencia por el conocimiento científico, no constituyeron características exclusivas del positivismo. Cuatro décadas después de su aparición en Europa, el positivismo era prácticamente desconocido en Cuba y una de las razones fundamentales de ese retraso fue de carácter ideológico" (127). Algunos jóvenes cubanos que 
Como resultado de esas lecturas de corte racialista, hacia la primera mitad del siglo diecinueve, los escritores cubanos buscan describir la sociedad, identificar sus males y aislarlos. Tanto para el sector más conservador y tradicionalista como para los letrados liberales, el mal de la sociedad cubana recaía en el negro esclavo, no sólo por el factor racial sino porque la esclavitud en tanto sistema no se correspondía con los ideales de la Ilustración: "razón, libertad, igualdad".

En consonancia con esta coyuntura, en este período los letrados reformistas articularán en diversos proyectos culturales la idea de que existe un "auténtico" sentimiento patriótico, un modo de ser cubano. No es casual, entonces, que hacia 1836 se acuñe la voz "cubano" por la cual se entiende "la persona o cosa natural perteneciente a la Isla de Cuba, si se trata de comparaciones o relaciones ultramarinas (o sea, con la Península)" (Leclerq 2004: 319). La cubanidad, esa especie de "macro imagen" se nutrirá de los valores simbólicos edificados desde este sector.

Como ya hemos señalado, Domingo del Monte y el círculo de letrados que lo acompaña, ubicados en una postura reformista, oscilan entre una actitud de signo "tradicionalista-conservadora" y una actitud "modernista-liberalista" para dar respuesta al interrogante sobre la identidad patriótica. En consecuencia, Domingo del Monte promueve un proyecto literario específico que tiene como cometido central fijar en el repertorio popular ciertos valores patrióticos encarnados en ciertos sujetos. Es decir, estos letrados idean un proyecto en el cual, acorde a su concepción Ilustrada de la literatura, ésta cumpla con una función educadora y edificante. Este proyecto es la escritura de un romancero cubano. En este repertorio, la cubanidad o identidad

habían ido a estudiar a Europa conocían esta filosofía y llegaron a identificarse con ella, como es el caso de Andrés Poey, quien reconoció las razones por las cuales no se había identificado públicamente con el positivismo al regresar la primera vez de Francia a Cuba a fines de la década del cincuenta del siglo XIX,- pero no podían manifestar públicamente su adhesión a la misma y se limitaban a hacer algunas referencias a sus principios en artículos científicos, tertulias, etc.

En 1864, Enrique Piñeiro publicó un interesante trabajo sobre el tema "La literatura considerada como ciencia positiva", en que aparece por primera vez una identificación clara con el positivismo a través de las ideas de Hipólito Taine. A partir de ese momento, el grado de maduración de la conciencia nacional cubana, que se manifiesta en la irrupción de la primera guerra por la independencia de España (18681878) fue creando premisas más favorables no para la divulgación -dado el aumento de la censura y la represión durante esta década bélica-, pero sí para que hombres como Enrique José Varona (1849-1933) comenzaran a imbuirse del pensamiento positivista. Es tan particular el Positivismo en Cuba y el Caribe que sugerimos la lectura del minucioso estudio de Pablo Guadarrama González Pablo (2004) Positivismo y antipositivismo en América Latina. 
patriótica se articula en la figura del "guajiro", campesino criollo blanco que trabaja la pequeña tierra, invadida y amenazada por el poderoso monocultivo del azúcar. La elección del guajiro nos permite pensar en una triple tensión: 1) con la sacarocracia, pues se revaloriza un pasado pre-industrial, 2) con la esclavitud, pues se excluye al sujeto negro como componente de lo cubano y 3) con las perspectivas más tradicionalistas/hispanistas con las cuales los reformitas mantienen ciertas distancias, pues anhelan el mismo estatus representacional del poder que detentan los criollos peninsulares.

\subsection{La patria imaginada por Domingo del Monte}

Las construcciones de representación colectiva sobre las cuales hemos venido reflexionando se apoyan en procesos que ligan la identidad a un espacio geográfico determinado, a una historia particular, a un grupo étnico y cultural específico. "Tierra", "historia", "raza" y "cultura" se convierten, de este modo, en elementos que definen y configuran simbólicamente una determinada idea de patria. Rafael Rojas considera que alrededor de los conceptos de patria y nación gravitan variantes metafóricas que permiten circunnavegar el universo simbólico que implican estas nociones. "Tierra", "sangre" y "memoria" constituyen para el crítico cubano el acervo metafórico sobre el cual se construyen las imágenes y representaciones de la identidad cubana.

En Motivos de Anteo (2008), Rojas propone revisar el proceso de construcción de identidad atravesado por Cuba a partir de considerar, por un lado, cómo operan estas metáforas, las cuales poseen un desarrollo histórico delimitado en tiempo y espacio, y por otro, analizar cómo generan campos semánticos descentrados y heterogéneos. Al respecto, advierte que la combinación y redefinición constante de estas metáforas ha permitido la elaboración en el desarrollo histórico cubano de una serie de discursos que configuran imágenes y representaciones de la identidad colectiva. Por otro lado, el modo en el que operan estas metáforas permite aclarar los límites confusos que separan a los conceptos de "patria” y "nación” y arribar a una definición más precisa:

La patria y el conjunto de sentimientos y representaciones que este concepto moviliza están relacionados con patrimonios y afectos territoriales, con identidades étnicas y religiosas que no necesariamente gravitan hacia la construcción de Estado nacional. 
La nación y el nacionalismo, en cambio son horizontes culturales y políticos más abarcadores que remiten a comunidades raciales, lingüísticas o confesionales, como en el Romanticismo, que se articulan a partir de principios republicanos o imperiales, como en las épocas neoclásica y moderna o que discurren en torno a identidades "espirituales", basadas en tradiciones, costumbres o "temperamentos" como sucede en tantas experiencias poscoloniales (Rojas 2008: 18).

El punto de partida del proceso complejo - y no ajeno a contradicciones - de construcción de una identidad colectiva es la conciencia de los sujetos de pertenecer a un grupo. Es por ello que, si bien Antonio Benítez Rojo (1989) advierte en Cuba la conformación temprana — a comienzos del siglo diecisiete- de una sociedad criolla, de una cultura criolla ligada a la industria de la producción de cueros, localizada en el área oriental de la isla, habrá que esperar hasta el tercer decenio del siglo diecinueve, en el contexto de expansión de la industria azucarera, para advertir en los criollos blancos la emergencia de una conciencia de grupo que se torna explícita en un caudal discursivo que busca delimitar y establecer los parámetros de la cubanidad.

En este sentido y recuperando la tesitura de Rafael Rojas, la racionalización de un patrimonio económico y simbólico podría ser definida como la forma depurada de autoconciencia intelectual de una cultura. La "memoria de la tierra y de la sangre" se despliega, en una primera instancia, como una de las metáforas a través de las cuales se hace perceptible este proceso de autoconciencia.

Esta racionalización de los discursos permite proyectar configuraciones identitarias que resultan de procesos de selección de aquellos elementos que "mejor" condensan la cubanidad. Por lo general, en esos discursos operan simultáneamente dos estrategias contrastivas: una de inclusión y otra de exclusión. Como sostiene Mónica Quijada: "Si algo caracteriza el proceso de selección de la memoria histórica en Hispanoamérica es el hecho de haberse desarrollado a partir de una dinámica oscilante que buscaba la continuidad en la ruptura, incluyendo y excluyendo alternativamente segmentos del pasado" (2003:17).

Este mecanismo puede advertirse en el proyecto cultural que impulsa Domingo del Monte: la escritura de un romancero cubano. En correspondencia con esta intención en el romancero decimonónico producido por Del Monte y un grupo de poetas 
allegados a su figura, se evoca con tono nostálgico un pasado pre-industrial, en el que se idealiza la campiña y el campesinado cubano. En este sentido, la memoria reconstruida opera como una forma de preservación y proyección de los intereses de los criollos reformistas interesados en hacer visibles los lazos raciales y culturales que "hermanan" a Cuba y a España.

La literatura proyecta el deseo de borrar el elemento discordante, es decir, el sujeto negro. La metáfora de la sangre que hermana en la hispanidad a Cuba y a España, separa indefectiblemente a los blancos de los negros. Como ya hemos señalado en el apartado sobre las retóricas del mestizaje, la mezcla de sangre entre blancos y negros es indeseable, pero al mismo tiempo se avizora como la única solución para lograr un paulatino blanqueamiento de la sociedad.

La metáfora de la tierra sufre desplazamientos que obedecen a diferentes formas de relación entre el sujeto y la tierra: del locus amoenus y la tierra paradisíaca al espacio arrasado por la máquina del ingenio. El carácter del vínculo entre sujeto/tierra también demarca procesos identitarios en transición. Por eso, una fórmula presente en el romancero es el destierro como metáfora de la tierra perdida, este aspecto lo analizaremos en el capítulo IV.

Los usos metafóricos crean imágenes de la tierra, de la sangre y de la memoria que operan como dispositivos generadores de sentido. En primer lugar, la memoria interviene respecto de los modos de interpretación del pasado y de la tradición, estableciendo márgenes, objetos y sujetos recuperables en relación a un sentido que se construye. En segundo lugar, la metáfora de la sangre permite revisar la valoración o subestimación del aspecto racial y la construcción de los lazos y vínculos culturales. Por último podemos afirmar que la metáfora de la tierra y su construcción como "paisaje", "dominio" o "naturaleza" también proporciona elementos de identificación colectiva que retomaremos en el análisis de un corpus de romances de la época.

El recorrido propuesto para este primer capítulo llega a su fin. La intención de esta primera parte ha sido desplegar las áreas de interés y los conceptos problemáticos medulares que definen y orientan nuestro trabajo. Por esto mismo se constituye como una apertura al universo de temas que se desarrollarán en las páginas siguientes, donde revisaremos las prácticas de sociabilidad de las letras cubanas adentrándonos en los 
gestos e iniciativas culturales que escenifican el anhelo de los letrados patriotas por fraguar una primera matriz simbólica identitaria. 


\section{Capítulo II}

\section{La sociabilidad literaria}

En este capítulo nos proponemos indagar en la configuración de los espacios de circulación y sociabilidad de las letras cubanas que se gestan en la década de 1830 a 1840 y que perduran en las décadas siguientes. El abordaje de estos ámbitos de promoción cultural tiene como objetivo caracterizar el medio letrado en el cual Domingo del Monte alienta el proyecto de un romancero cubano e instala entre sus contemporáneos el debate sobre las matrices simbólicas que buscan definir la identidad cubana.

Para ello, repararemos en distintos iniciativas que visibilizan de qué modo se trazó en Cuba un proceso de configuración de lo nacional que puede analizarse a la luz de otras experiencias culturales y sociales generadas en el mismo periodo en el continente hispanoamericano. En este sentido, la réplica de estas experiencias pone en escena elementos comunes que permiten considerar la formulación de un trayecto ideológico ilustrado de sesgo americanista.

Destacamos tres gestos que inauguran la necesidad de pensar y plasmar un proyecto identitario y estético diferenciador de la metrópoli, tendientes a legitimar al mismo tiempo los deseos de un sector criollo emergente que pretende configurar otros espacios de expresión y divulgación. Estos tres gestos son la conformación de la Academia Cubana de Literatura, las tertulias delmontinas y la creación de publicaciones culturales específicas como la Revista Bimestre Cubana.

Estos tres emprendimientos tienen a Domingo Del Monte como patrocinador. Es por ello que se analizarán en este capítulo ciertas configuraciones de autor y de literatura que se advierten en un corpus conformado por los informes que Del Monte eleva a la Comisión Permanente de Literatura de la Sociedad Económica de Amigos del País, como así también algunas notas de la Revista Bimestre Cubana y parte de su correspondencia compendiada en su epistolario personal, de modo de poder recuperar la voz de esta figura para entender por qué su presencia es definitoria en el ámbito letrado cubano sobre el tercer decenio del siglo diecinueve. 


\subsection{La institucionalización de los espacios literarios en Cuba: academias, tertulias, publicaciones}

\subsubsection{En búsqueda de la autonomía cultural: de la Comisión Permanente de Literatura a la Academia Cubana de Literatura}

La creación de espacios formales dedicados al estudio, lectura, disertación y publicación de la literatura en la isla se asocia a la fundación de sociedades que ya tenían una larga tradición en la Colonia. Es sabido que en las colonias de Hispanoamérica las instituciones tuvieron el rol principal de visibilizar los centros de representación y poder. Constituidas con el fin de representar la autoridad de la Corona, las instituciones coloniales tenían un fuerte carácter legitimador y de control (Romero 2001; Perilli 1995)

En Cuba, una serie de instituciones culturales se crean alrededor de la tercera década del siglo diecinueve ${ }^{44}$. Una de ellas es la Sociedad Económica de Amigos del País que se funda en Matanzas, en 1830. Esta sociedad ya existía en Santiago de Cuba, cuando veintisiete habaneros, pertenecientes en su inmensa mayoría a la antigua nobleza criolla delegaron en cuatro de sus más destacados compañeros (Juan Manuel O’Farill y Herrera, Francisco José Bassave y Cárdenas, el obispo Luis de Peñalver y Cárdenas y el conde de Casa Montalvo, Ignacio Montalvo y Ambulodi) para que trataran junto con el Capitán General Luis de las Casas Aragorri, sobre la instalación

\footnotetext{
${ }^{44}$ Para dilucidar el concepto de "institución" y su aplicabilidad a las agrupaciones que caracterizamos, seguimos los aportes de François-Xavier Guerra (2003). En el Antiguo Régimen las prácticas políticas eran ejercidas por múltiples autoridades que Guerra clasifica en autoridades regias y corporativas. Las primeras eran las que gobernaban en nombre del rey (virreyes, gobernadores, audiencias, etc.) mientras que las segundas eran una extensión del cuerpo político e incluían a las diferentes instituciones y agrupaciones cuya autoridad no provenía del rey (como la de los obispos, las señoriales, etc.). Guerra señala tres momentos en las prácticas y concepciones de la política: el Antiguo Régimen, Absolutismo (como momento bisagra) y la Modernidad. Hasta el Absolutismo, bien tardío y por otra parte con escasa incidencia en el ámbito hispanoamericano, y con más limitaciones que en el modelo francés, el papel del rey no absorbía todas las potestades ni funciones de gobierno, sino que éstas estaban distribuidas en todo el cuerpo político, razón por la cual se consideran legítimas las múltiples autoridades y no solo las que provienen del rey. Solo con el Absolutismo, y con el paso de una concepción de soberanía múltiple a una indivisa y de carácter abstracto (esta sí, ya propia de la Modernidad), los derechos de los cuerpos pasarán a considerarse 'privilegios' en nombre de la igualdad moderna. Hasta la Modernidad, la política es jerárquica y de grupos, y los distintos cuerpos consideran que tienen derechos distintos de los de otros, pues ese es el orden natural. En resumen: los actores políticos coloniales eran múltiples e incluían no solo las instituciones más tradicionales que conocemos sino también las asociaciones como cofradías, gremios, tertulias, etc.
} 
en La Habana de una Sociedad Económica de Amigos del País, a semejanzas de las que ya existían en la metrópoli. Con ese fin, fundan en 1792 la Sociedad Económica de Amigos del País de La Habana. La delegación de Matanzas formaba parte de la Sociedad de La Habana (Ortega 2006).

Estas instituciones coloniales reforzaban los lazos culturales entre las colonias y la metrópoli, pero también cumplían otras funciones como la de asignar poder al grupo selecto que las integraba. Pues pertenecer a estas sociedades significaba ser miembro de una elite ilustrada, de una minoría que se autolegitimaba en un espacio de decisión sobre distintas competencias temáticas. Los letrados que formaban parte de estas sociedades se vinculaban con miembros de otras sociedades, razón por la cual, el intercambio de publicaciones y el epistolario, como así también los viajes de carácter diplomático eran prácticas de sociabilidad frecuente.

El 3 de febrero de 1830, Domingo Del Monte logra ser admitido en la Sociedad Económica de Amigos del País de Matanzas, recientemente fundada. Junto con otros jóvenes tiene una presencia activa en la Sección de Educación y en la “reunión de literatura". No es casual que ese mismo año el ensayo Memoria sobre la vagancia en Cuba de José Antonio Saco resultara premiado y que fuera tomando cuerpo la formación de una Comisión Permanente de Literatura dentro de la Sección de Educación. A fines de ese mismo año, Domingo del Monte es nombrado encargado de la Sección de Educación de la Sociedad Económica de Amigos del País.

Para Del Monte, trabajar en pos de la educación era esencial pues considerada que era el medio por el cual Cuba podría dejar atrás la ignorancia en la que estaba sumida. Junto a José de la Luz y Caballero (1800-1862) Del Monte inicia una intensa actividad respaldado por los otros miembros de la comisión para crear una amplia red de escuelas gratuitas en las zonas rurales y apoyar y promover la creación de colegios en las ciudades. El relevamiento de la situación educativa en Cuba llevado a cabo por Del Monte se traduce en dos acuciosos informes sobre el estado de la educación pública que presenta a la Junta de la Sociedad entre los años 1831 y 1836: “Exposición de los trabajos en que se ha ocupado, en el año 1831, la Sección de Educación de la Real Sociedad Patriótica" e "Informe sobre el estado actual de la enseñanza primaria en la Isla de Cuba en 1836, su costo y mejoras de que es susceptible". Con estos 
relevamientos, Del Monte pretende ofrecer "una estadística de nuestras escuelas, para dar datos exactos y calcular número de establecimientos, alumnos, maestros, métodos adoptados (...) a los efectos de precisar la situación verdadera en que nos hallamos" (Del Monte 1831: 256).

La estadística revela que en La Habana hay unos 20.827 niños (de 4 a 15 años) y niñas de (5 a 12), de los cuales 4000 niños y 5783 niñas reciben algún tipo de instrucción literaria, ya sea en institutos o en sus casas particulares. Otros 2000 niños reciben instrucción de un oficio en algunos talleres y algunas niñas, instrucción del trabajo doméstico. Sin embargo, el bajo índice de escolaridad preocupa a Del Monte, quien ante la Junta postula con alerta: "aún subiendo los índices que sepan leer (...) se quedan irremisiblemente y lastimosamente perdidos para la religión, la moral y la patria, 4000 niños y 3000 niñas" (Del Monte 1831: 256).

La pretensión de racionalidad (propia de la Ilustración) imprime todo el trabajo de investigación, de ahí surge la necesidad de obtener datos precisos, es decir, una estadística que permita diagnosticar la situación y, en correspondencia, establecer una metodología adecuada que posibilite solucionar las deficiencias advertidas. De este modo, Del Monte inicia como encargado de la Sección de Educación una tarea consecuente de sondeo y control del estado de la educación en Cuba ${ }^{45}$.

Pero el intento de promover la educación pública como método para reformar la sociedad encontró en la propia constitución social los obstáculos que impidieron tal reforma. Las estructuras económicas y sociales establecidas en Cuba hacían inviable hacia 1830 un proyecto de educación como el que pretendía Domingo del Monte, es decir, un proyecto de educación mediante el cual se ampliara el número de niños de ambos sexos, blancos y de color que accedieran a la educación primaria. Este informe

\footnotetext{
${ }^{45}$ El trabajo de relevamiento abarca toda la isla de Cuba tal cual lo demuestra el Informe de 1836 (Primera parte, apartados I, II y III). En los distintos pueblos hay preceptores ocupados en la tarea de sondear y realizar los registros que luego son elevados a la comisión. En los comentarios vertidos por el propio Domingo del Monte en el Informe que eleva a la Junta de la Sociedad Económica del Amigos del País da cuenta respecto del desempeño de los inspectores de escuelas, cargo que él mismo cumpliría y bajo el cual supervisa las escuelas de los barrios de Santa Teresa, Santa Clara y Espíritu Santo en 1833.
} 
arrojó como dato la cifra de 104.400 niños y niñas, blancos y de color libres que no recibían educación ${ }^{46}$. En palabras de Del Monte:

[104.400 niños y niñas] que sufren en medio de la bastarda riqueza agrícola de la isla de Cuba, la misma carencia de la enseñanza primaria, primer elemento de toda verdadera civilización, que sufren por la barbarie de su estado actual los salvajes del Uruguay .(...) Necedad sería comparar el deplorable estado de la enseñanza primaria de Cuba con el estupendo de los Estados Unidos de América del Norte, la Prusia de Bengala y en sentido contrario con la Rusia, el Portugal y la parte meridional de Francia.

El número 104.400 que nos resultan en la isla sin que tengan materialmente donde aprender siquiera a leer y escribir, en una población de 500.000 personas blancas y de color libres, debe llamar por sí enérgicamente la atención de los hombres sensatos y pensadores de Cuba y su metrópoli.

Un gobierno sabio mirará esta enorme masa de cien mil ignorantes, cien mil revoltosos proletarios, enemigos de la tranquilidad del país, y se interesará sinceramente en la aventura de éste, procurará afianzar en él el orden, difundiendo y costeando escuelas primarias conforme a los progresos intelectuales y morales de la época presente, como lo ha hecho el de la Prusia, y conquistar así a fuerza de luces la paz, la riqueza sólida y la moralidad futura de esta preciosa Antilla (Del Monte 1836: 27).

Hay dos frentes que le interesan a Del Monte, uno es el de la educación y de ahí la necesidad y el rol activo que asume como miembro de la Sección de Educación. El otro frente es la literatura, y por ello crea un espacio definido para las acciones referidas a ésta: la reunión de literatura se convierte bajo la organización de Domingo del Monte en una Comisión Permanente integrada por una camada de jóvenes ilustrados como él que disputaban con los mayores una agenda de prioridades.

\footnotetext{
${ }^{46}$ En 1835, hay en la ciudad de La Habana 73 escuelas para niños varones y blancos; 51 escuelas para niñas blancas, 6 escuelas para niños de color libres y 1 para niñas de color libres. El registro elevado por Del Monte indica que en el resto de los partidos, el índices de escuelas es mucho más bajo o nulo. De los 119.519 niños de ambos sexos, blancos y de color libres que pueden recibir educación, hay 104.400 que no la reciben. Los registros completos son publicados por José Antonio Fernández de Castro (1929) en Escritos de Domingo del Monte.
} 
La incipiente institucionalización de tareas relacionadas con la educación y la literatura no solo permitió registrar, diagnosticar y evaluar el estado de cultura del pueblo cubano. Trajo consigo, además, el desarrollo de otro tipo de relaciones: las redes entre letrados. El contacto con escritores, críticos y pensadores de otros países que cumplían funciones en carácter de corresponsales tuvo un doble beneficio, por un lado, con su autoridad sumaban prestigio a estas instituciones y, por otro, favorecían el diálogo y la interacción con otros intelectuales, posibilitando la apertura de Cuba.

Domingo del Monte propuso que la Comisión Permanente de Literatura esté integrada por individuos que "bien por su celo en el adelanto de la civilización cubana, bien por su nombradía literaria justamente adquirida" den lustro a la Comisión. En la "Exposición de las tareas de la Comisión Permanente de Literatura, durante el año 1831" que eleva dando cuenta de lo actuado expone los tres nombres elegidos: José Manuel Quintana, Don Agustín Durán (Madrid) y Don Felipe Poey (habanero residente en París ${ }^{47}$. Al respecto de los ilustres colaboradores, Del Monte señala:

Las brillantes dotes que adornan al señor Quintana, patriarca de nuestro parnaso y cuya reputación de poeta eminente, de historiador integérrimo y de crítico exquisito, no podrá menos de honrarnos, y el ofrecimiento de este literato y el señor Durán, tan apreciable por su sazonada erudición y el buen gusto que manifiesta en sus recientes publicaciones, han hecho a la comisión de emplearse en su obsequio, y cooperar con ella a la mejor dirección de sus tareas es la más cumplida fianza del acierto de nuestra elección y de nuestro buen deseo. El señor Poey, por las relaciones de paisanaje que lo une a nosotros, por la asidua aplicación con la que ha observado los objetos naturales de nuestra isla, y por el estudio que ha hecho de la literatura española, nos servirá tan bien y tan a propósito como la ha demostrado con la Sección de Historia... (245).

En el informe que Del Monte eleva a la Sociedad Económica refiere las acciones llevadas adelante por la Comisión Permanente de Literatura, entre las cuales destaca un concurso poético y la creación de un diccionario de provincialismos. Domingo del Monte se hace eco en tanto vocero de la Comisión de la importancia de estos actos. Sin

47 “Informes y exposiciones pedagógicos” (1831-1836) en Escritos de Domingo del Monte (1929). 
embargo, más allá del impacto específico, es interesante leer en esos gestos culturales el intento de una nueva generación como la de este hombre de letras por posicionarse en el medio y crear una nuevo estatus literario, instalar temas y géneros y destacar personalidades.

En el concurso, a pesar de que tiene como tema el nacimiento de la infanta de Castilla, Isabel de Borbón, Del Monte señala que "el influjo que tuvo este concurso, el primero que se ha abierto en esta Antilla, contraído puramente a poesía es incalculable. Con él se inflamó el entusiasmo de nuestra juventud por esta especie de estudios tan descuidados por nuestros padres, a causa de la incuria de los tiempos y tan escarnecidos en casi su totalidad en los nuestros por el avillanamiento y la ignorancia de los menguados poetastros que los profanaban" (246).

Para nuestra lectura es relevante destacar algunas marcas que permiten situar y definir el espacio discursivo desde el cual se inscribe Domingo del Monte. En primer lugar, aparece la idea de lo nuevo y lo novedoso, de lo que no ha sido nunca realizado. El concurso es el "primero" de tales características. Luego, se advierte la identificación del yo que enuncia en la expresión "nuestra juventud" a la que liga el "entusiasmo" y, al mismo tiempo, opone a la expresión "nuestros padres", generación atada al "descuido".

La marca temporal también permite pensar el cambio que Del Monte quiere provocar en la literatura: la renovación. Así como la juventud le pertenece, estos "tiempos nuestros", dice el autor, son tiempos en los cuales se profana la poesía. Instala de este modo el agravio sobre la letra en el plano de lo sagrado, y sitúa en esta esfera lo literario.

En la misma exposición Del Monte también indica el fracaso de un segundo certamen poético y, entre las causas que define "fáciles de explicar", cita: "Los temas que contenía estaban más bien calculados para una nación populosa y formada, instruida de mucho tiempo atrás en este linaje del saber, que para un pueblo nuevo como el nuestro en la senda espinosa de las humanidades" (247).

En este sentido, Del Monte advierte una carencia, la misma que trata de visibilizar cuando expone las cifras alarmantes sobre los índices de educación. Esta carencia se relaciona con la juventud del pueblo cubano en relación a otras naciones. 
Sin embargo, este no saber poético no es degradante en sí mismo, sino la consecuencia directa de lo que no se cultiva, un arte que lleva años aprender. Al mismo tiempo, a Del Monte le interesa el valor pedagógico, de formación moral que encuentra en la literatura. En esta carencia, actúa el programa estético e ideológico que impulsará en relación al romancero de su autoría.

En cuanto al diccionario, tiene como gesto cultural la intención de fijar y normar vocablos y usos léxicos. Al ser un diccionario de provincialismos, contribuye además en la configuración de una identidad diferenciada con respecto a España. Del Monte afirma que este trabajo en torno al diccionario surge de la necesidad de “designar voces provinciales que indican objetos naturales que no hay en España y que por lo mismo es necesario adoptarlas por los escritores de América” (248).

La intención — según expone en el informe- es que la obra incluya un apéndice en el cual se listen alfabéticamente "vocablos corrompidos que han logrado introducirse por contrabando en nuestro lenguaje familiar, y aun en nuestro foro, provenidos en general de nuestro trato con maleantes andaluces y los extranjeros, que han plagado la lengua castellana de mil solecismos y anomalías con su índole primitiva" (249). En consonancia con este registro cabe recordar que en 1836 se publica la primera edición del Diccionario Provincial casi-razonado de Vozes Cubanas que contiene un "Suplemento" de "Vozes corrompidas" en el cual "se listan no los disparates y defectos de locuciones particulares sino aquellos muy generalizados aun entre las personas cultas" (Pichardo y Tapia 1862: VI). Con motivo de la tercera edición en 1862, su autor, señala en el "Prólogo" que esta nueva edición surge de nuevos estudios e indagaciones que le han permitido completar el diccionario. Como sostiene Félix Córdoba Rodríguez:

Con este diccionario cubano comenzaba la larga tradición de diccionarios diferenciales del español de América, es decir, de diccionarios que recogían exclusivamente el léxico de la región que no se considerase español general; más aún, normalmente se incluían solo los elementos que (se creía que) no se encontraban en España. Como la norma de prestigio era la de la metrópoli, 
estos diccionarios no podían contemplarse de otra manera que como una colección de aberraciones (1999: 52) ${ }^{48}$.

El informe presentado en 1831 pone en relieve las preocupaciones lingüísticas que Del Monte compartía con su grupo y si bien el diccionario de Pichardo que se publica unos años más tarde dará cuenta de un interés diferenciador del castellano según los usos regionales americanos, la preocupación de Del Monte por la "pureza” idiomática se presenta como signo de cohesión cultural con España. La lengua es para este grupo la "lengua de la madre patria", de este modo, mientras que la latinidad une y conserva, otros factores coyunturales ligados a la economía y a las crisis políticas generan ambigüedad en las relaciones con la metrópoli española.

Por último, cabe mencionar que otra de las funciones ejercidas por la Comisión fue la de evaluar y corregir un estudio de gramática perteneciente a Juan Olivella y Salas $^{49}$.

${ }^{48}$ En el mismo estudio, Félix Córdoba Rodríguez señala un antecedente interesante: “en 1795, el clérigo José María Peñalver informaba a la Sociedad Patriótica de La Habana que preparaba un Diccionario provincial de la Isla de Cuba, que no se llegó a publicar y de cuyos materiales no se tiene noticia. A pesar de que dicho diccionario no existe, sus planteamientos, recogidos en la Memoria que presentó Peñalver, indican un cambio radical en el tratamiento de léxico americano, pues se proponía recoger, aparte de palabras de origen indígena, "Voces de origen castellano mal pronunciadas en Cuba, o que en ella han llegado a tener un sentido diferente al de España", "términos burlescos y jocosos que ha adoptado el uso de la Provincia, aunque no los usen los "eruditos", ni los "literatos": basta que los practique familiarmente el vulgo criollo", así como vocablos "usados por los negros por corrupción de palabras castellanas, con tal que las usaran también los blancos"13. Por primera vez el léxico americano en cuanto tal, el español de América, merece que se le dedique un diccionario. La idea de que se trata de voces corrompidas está presente - lo seguirá estando durante mucho tiempo, hasta entrado el siglo XX - pero ya no impedía que fuesen recogidas y que se les dedicase una considerable atención” (51).

${ }^{49}$ En Historia de las letras y de la instrucción pública de la isla de Cuba, de Antonio Bachiller y Morales (1860) en la Cuarta Parte se expone el "Catálogo de libros y folletos publicados en Cuba desde la introducción de la imprenta hasta 1840". El detalle del catálogo permite advertir otra obra de Juan Olivella y Salas que se publica en 1829, se trata del Método breve y fácil para enseñar a leer en corto tiempo (Un tomo en $4^{\circ}$ con 85 páginas). Y en el año 1831, del mismo autor sale la publicación de la Nueva gramática de la lengua castellana para el uso del colegio Buenavista y de la Segunda edición corregida y simplificada de Método breve y fácil para enseñar a leer en corto tiempo (en $4^{\circ}$ y 19 páginas). Bachiller y Morales ofrece además otro exquisito catálogo en la Sección II sobre las "Publicaciones periódicas, catálogo razonado y cronológico hasta 1840 inclusive" Ambos catálogos permiten recuperar y analizar el amplio espectro de publicaciones que circularon en Cuba desde 1724 hasta 1840. El estudio de estas listas permiten el trazado de hipótesis sobre la configuración del mercado editorial, las librerías y las imprentas en el período consignado, como así también proyectar representaciones sobre el público lector, diverso y fragmentado. 
Las gramáticas como los diccionarios son textos que proponen la convención respecto de determinados usos y formas. Establecen, además, aquello que se considera dentro de la norma y por lo tanto, lo correcto. Una gramática tiene un valor simbólico que reside justamente en este carácter normativo.

Las funciones llevadas a cabo por Del Monte desde la Comisión Permanente de Literatura ponen en evidencia la creación de un espacio formal en el cual se discuten y dirimen cuestiones medulares relacionadas a las letras cubanas de la primera mitad del siglo diecinueve. Desde su arribo a la Sociedad Económica, Del Monte y su grupo pretenden, en primer lugar, posicionarse en el círculo de letrados mayores pero, al mismo tiempo buscan marcar las diferencias, pues ellos se presentan como un grupo de ilustrados que quieren imprimir modernidad a las tendencias estéticas vigentes a partir de la renovación y la incorporación de otras prácticas literarias ligadas a la producción cultural, como lo es la creación de una comisión autónoma de literatura y la creación de una publicación bimestral, gestos que lograrían expresar con mayor conciencia las ideas políticas y estéticas del grupo. En este sentido, toda la labor de Del Monte está orientada a la configuración de un nuevo universo cultural y simbólico que redefine en términos identitarios las esferas de lo cubano y lo criollo.

Bajo esta premisa y mientras ejerce la función de secretario de la Comisión Permanente de Literatura, Domingo del Monte impulsa en 1831 la creación de una publicación bimestral denominada Revista Bimestre Cubana.

Dos años después se concreta el anhelo de los ilustrados que acompañaban a Del Monte de convertir la Comisión Permanente de Literatura en una academia autónoma. Esta aspiración se materializó en 1833 con la muerte de Fernando VII y el nombramiento de su viuda y sobrina, María Cristina de Borbón, como reina regente, quien emitió, el 25 de diciembre de ese año, una Orden que establecía la creación de una Academia Cubana de Literatura, para la cual Del Monte fue nombrado Secretario. En la primera reunión se eligen a Nicolás de Cárdenas como director y a Blas Osés como vicedirector; se nombró la comisión que debía redactar los reglamentos la cual quedó integrada por Domingo del Monte como secretario, Blas Osés, Anastasio Carrillo y Manuel González del Valle. También son designados José Antonio Saco, Vicente Osés y Pedro Sirgado para redactar la acción de gracias a la Reina. 
Tanto Del Monte como quienes lo acompañaban en la Academia se llamaban seguidores de las ideas de Varela (señalado como el primer pensador que propuso una idea de la patria cubana autónoma) (Amores Carredano 2007) por lo que dirigieron sus esfuerzos a crear una conciencia encaminada a extinguir el comercio de esclavos. Los ataques contra éste, especialmente los artículos publicados por Saco acerca de la trata, desataron una fuerte oposición de los comerciantes negreros, hacendados conservadores y autoridades coloniales. Entre los principales opositores se encontraban el Director de la Sociedad Económica, Juan Bernardo O’Gavan y el Secretario de Hacienda, Claudio Martínez de Pinillos. El 12 de abril de 1834, el secretario de la Sociedad, Antonio Zambrana publica un artículo en el Diario de La Habana bajo el seudónimo "Socio Amante de la Literatura y del Orden" en el cual afirmaba que la Academia se había creado a partir de métodos arbitrarios y relacionados a otros intereses, más políticos que literarios. Por lo que el Capitán General suspendió toda publicación de cualquier papel relativo al establecimiento de la Academia, pero Saco desobedece esa norma y publica un trabajo con el título "Justa defensa de la Academia Cubana de Literatura", el cual provocó que tanto O’Gavan como Pinillos se sintieran aludidos. Como consecuencia, ambos solicitaron al Capitán General Miguel Tacón y Rosique la expulsión de Saco de La Habana. La derrota del grupo de la Academia quedó sellada con la Real Orden de 18 de octubre de 1834 que sentenciaba el destierro de Saco, la disolución de la Academia y la suspensión de la revista ${ }^{50}$.

Aunque fracasa la constitución de un espacio autónomo de discusión, es tal la importancia que alcanza en la isla y fuera de ella la publicación de la Revista Bimestre Cubana que encontramos necesario dedicar algunas páginas para explicar la irrupción de esta revista en el ámbito cultural tanto como su impacto y trascendencia.

Sin embargo, antes de analizar el periodo de emergencia y la implicancia para la configuración del ámbito letrado que tuvo la revista Bimestre, nos detendremos en dos fenómenos ligados al universo letrado y a la figura de Del Monte que exponen los

\footnotetext{
${ }^{50}$ El traslado de Domingo del Monte de La Habana hacia Matanzas acontecido en abril de 1834 no solo se debe al matrimonio que contrae con María Rosa Francisca Aldama y Alfonso también ha sido explicado por los biógrafos como una manera de ausentarse cuando estalla el conflicto entre el director de la Sociedad Económica, Juan Bernardo O’Gavan y José Antonio Saco. Para una reposición del contexto de la polémica ver las notas de Sofhie Andioc (2002) en la "Presentación" al Tomo II del Centón epistolario de Domingo del Monte.
} 
cambios producidos en esta década de 1830 a 1840 en lo que respecta a las formas de sociabilidad y circuitos de lectura y cómo ello produce cambios en las formas de legitimación autoral de los letrados. Estos dos fenómenos son las tertulias y la intensa actividad en torno a las publicaciones periódicas.

\subsubsection{Las tertulias delmontinas: una expresión de los nuevos espacios públicos}

Las tertulias que se fundan en el siglo diecinueve en Hispanoamérica constituyen uno de los principales espacios de sociabilidad puesto que permiten la expresión de los ciudadanos sobre diferentes temas ${ }^{51}$. No obstante, si bien adquieren una valiosa función en este periodo, las tertulias expresan una modalidad de encuentro que reúne elementos de las formas más tradicionales de la sociabilidad hispánica: la visita de conversación y cumplimento, y la reunión más o menos espontánea de amigos de similares condiciones sociales para entretenimiento, sin que, en principio, la utilidad formara parte de sus objetivos de reunión. Hecho que comprueba una vez más que el siglo diecinueve expone una compleja relación entre habitus conservadores y prácticas modernas. Casi un continuum en el cual se producen tensas y paradojales relaciones de superposición y contraposición ${ }^{52}$.

Al respecto, como explica Andreas Gelz (2009) en su estudio sobre las relaciones entre prensa y tertulia en España, las tertulias son un fenómeno histórico-

${ }^{51}$ En América Latina el proceso de construcción de ciudadanía política se relaciona directamente con el proceso de construcción de los Estados-nación modernos. Sin embargo, la experiencia de transformación de las monarquías en naciones modernas fue diverso, tanto que cuando ya casi todos los estados americanos habían iniciado algún proceso de independencia, Cuba continuaba ligada colonialmente a la monarquía española. Por eso, la denominación de "ciudadano" como aquel sujeto de derechos políticos y de representación no sería la más adecuada para referirnos a quienes integraban la sociedad cubana en el periodo que ocupa esta investigación.

Por ejemplo, en el contexto mexicano, la condición de "vecino" ha sido utilizada en algunos estudios (Carmagnani y Hernández 2003) para explicar la situación de los actores sociales en un primer paso en el camino hacia la obtención de derechos políticos.

No obstante, también se encuentran usos de la palabra "ciudadano" sin las restricciones relacionadas a los derechos políticos, es decir, en un sentido amplio. Como sostiene Hilda Sábato "en buena parte de Iberoamérica la independencia introdujo un concepto relativamente amplio de ciudadano que tendía a incluir a todos los varones adultos, libres, no dependientes, lo que se acercaba más al citoyen de la Francia revolucionaria" (Sábato 2003:19).

${ }^{52}$ Muestra de la continuidad de la tertulia en el siglo veinte en Cuba son las reuniones realizadas desde 1920, en la tertulia literaria del antiguo café del teatro Martí, a las que concurren entre otros Rubén Martínez Villena, Andrés Núñez Olano, Enrique Serpa, Alberto Lamar Schweyer, Ramón Rubiera y Rafael Esténger. Estos encuentros que dan origen al "Minorismo" o "Movimiento Minorista". Ver Manzoni 2001: 150. 
cultural que hunde sus raíces en el siglo diecisiete (en relación a la academia literaria radicada en el ámbito privado) y encuentra sus precursores en la Academia humanista del Renacimiento, surge en el siglo dieciocho y vive su momento de plenitud en el diecinueve.

Si bien Gelz aborda como campo de estudio el fenómeno de las tertulias en España en el siglo dieciocho, coincidimos en la mirada que realiza respecto de la relación estrecha y fecunda que existe entre prensa y tertulia, y sus aproximaciones teóricas permiten pensar cómo se comporta ese mismo binomio en Hispanoamérica y específicamente, en Cuba.

Dice Gelz:

Un paralelo fundamental entre prensa y tertulia $-\mathrm{y}$ con ello una razón para la indagación de su relación mutua- reside en el hecho de que ambas representan formas de comunicación y conforman espacios en los cuales, en diferentes niveles, ciertos procesos de interacción se hacen habituales (con diversos grados de institucionalización). El vínculo entre prensa y tertulia se vuelve al mismo tiempo más estrecho, en la medida en la cual se avanza hacia una interpenetración de las formas de comunicación oral y escrita, hacia una dinámica de circulación interdependiente de dos sistemas de comunicación (en la tertulia se habla de textos escritos, y a su vez esta conversación misma es fijada en la escritura). Esta interdependencia, y con ello la circulación de la tertulia más allá del círculo de sus miembros — por medio de su puesta por escrito- opera a su vez efectos en la cohesión de la tertulia y en su autopercepción, conformada a través de procesos de comunicación. Así, la tertulia también ejercerá su influencia en la emergencia de la esfera pública (3).

Retomaremos más adelante qué características presenta esta relación intermedial ${ }^{53}$ entre prensa y tertulia en el periodo cubano que nos ocupa.

Ahora bien, como ya adelanta la cita de Gelz, el abordaje de las tertulias como nuevos ambientes de debate y formación de opinión, traslada el foco de estudio hacia la conformación y características de los espacios privados y los espacios públicos en

\footnotetext{
${ }^{53}$ Gelz emplea esta denominación que consideramos funcional para explicar las interrelaciones que se establecen entre prensa y tertulia. Interacción, comunicación y sociabilidad son procesos de ida y vuelta que distinguen el intercambio que se genera entre estos dos espacios.
} 
América Latina. Como sostienen François-Xavier Guerra y Anick Lempérière (1998) hasta principios de la década del noventa del siglo veinte la problemática del "espacio público" era una tierra ignota en la historiografía iberoamericana, no solo en sí misma sino porque muchos de los términos que engloba también eran desconocidos.

Las causas de este vacío, según estos autores, obedecen a metodologías y a los problemas que cada época considera relevantes. Ofrecen como ejemplo que los historiadores de la Segunda Guerra Mundial se abocaron al estudio de los problemas sociales y económicos dejando de lado aquellos aspectos relacionados a la historia política e institucional ligada a la edificación de la nación. De este modo, las cuestiones de carácter esencialmente cultural y político que ocupaban a los estudiosos quedaban fuera de las perspectivas de investigación.

Recién en los setenta y ochenta, la transformación intelectual que agitó a Europa y que coincidió con las dictaduras del mundo ibérico posibilitó la creciente valoración de los estudios "formales" de los regímenes políticos modernos.

Los problemas centrales del siglo diecinueve - la construcción de la nación, la constitución, la representación política, la ciudadanía, las elecciones, las libertades individuales, la opinión pública — volvieron a ser objetos centrales de la reflexión contemporánea y de los historiadores también.

En este sentido, se han renovado los campos de investigación y aunque en algunas áreas están en su etapa incipiente de relevamiento de datos, Guerra y Lempérière presentan algunas conclusiones sobre el carácter de estas investigaciones que es válido mencionar:

1. Se imbricaron temas cuyo estudio se realizaba en forma aislada.

2. Se detecta la importancia que para todos estos fenómenos tiene el periodo que va de finales del siglo XVIII a mediados del siglo XIX, es entonces cuando se produce la mayor de las transformaciones que se designa con el término Modernidad.

3. Se evidencia la necesidad de un enfoque comparativo, pues los estudios parciales muestran que existe un área cultural común que se podría denominar "latina". 
El trabajo desarrollado por estos autores en América Latina es insoslayable para comprender la importancia que adquieren los espacios públicos emergentes en tanto propician la participación y con ello, la representación ciudadana ${ }^{54}$.

Hasta mediados del siglo diecinueve, irrumpen y se legitiman una serie de espacios públicos que son lugares concretos, tales como las plazas, la calle, el congreso y la imprenta, entre otros, en los cuales las elites criollas desarrollan una incipiente conciencia de clase con pretensiones de autonomía. Para Guerra, estos espacios adquieren importancia en la medida en que permiten registrar el cambio de pensamiento que origina la caída del Antiguo Régimen ${ }^{55}$.

Pero en relación a estos espacios, las tertulias tienen características singulares. Con consenso son definidas como espacios privados o semiprivados, o aún espacios públicos utilizados de manera privada, de conversación y discusión que funcionaban en las habitaciones de los estudiantes, en los colegios, en casas de particulares e incluso en bibliotecas públicas. Es necesario aclarar que ninguna especialidad física es de por sí pública o privada, sino que son las prácticas sociales y los actores en el acontecimiento los que dotan de un cierto carácter público o privado a un conjunto de espacios.

\footnotetext{
${ }^{54}$ Como señalan Guerra y Lempérière, en el siglo veinte se realizan numerosos aportes desde distintos ámbitos disciplinarios que tienen como objeto de estudio la configuración de los espacios públicos en relación a la edificación de las naciones. Sobre los espacios de lectura y las nuevas prácticas de sociabilidad en el ámbito latinoamericano del siglo diecinueve pueden revisarse los solventes trabajos de Zanetti (2002); Alcibíades (2004); Renán (2005); Acosta Peñaloza (2005); Beauregard (2007); Sábato (2008) entre otros. La lectura de estos estudios permite trazar líneas que mapean entre geografías políticas y económicas tan dispares como las de Argentina, Venezuela, Colombia, Perú, Chile similitudes en torno al fenómeno de nuevas prácticas de sociabilidad.

55 Es voluminosa la bibliografía referida a este tema. Consideramos insoslayables los aportes de Eric Hobsbawn en The Age of Revolution: Europe 1789-1848(1962) y en Nation and Nationalism since 1780: programme, myth, reality (1990) Retomamos la formidable síntesis que realizan Guerra y Lempérière -pues son los autores seguidos en el desarrollo de este capítulo- en torno a esta compleja definición: "La expresión misma, Antiguo Régimen, designa algo que era claro para los hombres del periodo revolucionario: una heterogeneidad entre dos épocas de la historia humana. Para ellos $-\mathrm{y}$ esta misma conciencia es una de las principales novedades de la época - el tiempo que están viviendo es un periodo de ruptura, de novedad, de invención que deja atrás imaginarios, valores y prácticas de una época pretérita de la humanidad. El Antiguo Régimen es un largo período histórico que hunde sus raíces en la Edad Media y la feudalidad y se prolonga en muchos campos y en muchos ambientes hasta la Ilustración" (Guerra y Lempérière 1998: 12). Estos autores se proponen repensar el Antiguo Régimen, prestando especial atención a las palabras y sus usos, pues consideran que los imaginarios y las representaciones colectivas a los que el lenguaje remite son parte esencial de la realidad. No es un problema terminológico, sino que tiene que ver con la forma en que los hombres de una época se conciben a sí mismos. Esta perspectiva permite una revisión - aunque su recuperación sea insoslayable para los estudios críticos - de los enfoques más tradicionales sobre la Modernidad y sus problemas, tal es el caso de la mirada propuesta por Jünger Habermas.
} 
Las nuevas pautas de sociabilidad que inauguran las tertulias se pueden sintetizar en formas de encuentro en las que dentro de condiciones formales de igualdad de participación de hombres y mujeres, y en un ambiente de lectura, las opiniones empiezan a confrontarse, a mostrar puntos de apoyo argumentativo inéditos (como el testimonio, la observación y la medida) que manifiestan cómo las condiciones de verdad de un juicio y las maneras de someterlo a prueba se modifican ${ }^{56}$.

Entre las prácticas sociales que cambian está la de la lectura. En este sentido, las tertulias son espacios singulares en donde conviven las dimensiones de lo privado y de lo público, pues se trata de recintos domésticos a los que asisten personalidades ilustres. Además, porque lo que se "produce" en la tertulia de alguna manera sale al exterior; es decir, hay una circulación de materiales, opiniones que luego se vuelcan en escritos, en la prensa, o vuelve al ámbito de lo privado en el universo del intercambio epistolar.

En las tertulias, la práctica de la lectura se vuelve colectiva, no es un espacio destinado a la lectura silenciosa, sino a la lectura en voz alta y al ejercicio de la opinión crítica respecto del material que se comparte. Es decir, hay una metodología que rige la participación en las tertulias, por ejemplo, con respecto a la lectura de un libro se enfrentan los diferentes puntos de vista y se dirimen mediante un examen de las distintas opiniones de quienes asisten al encuentro.

En torno a las tertulias decimonónicas en Hispanoamérica se observan algunos fenómenos tales como la creación en medios urbanos de asociaciones en el marco de las cuales la lectura llegó a ocupar un lugar central, la creación de algunas redes de lectores en el campo y el nuevo interés que se da por la lectura de las gacetas, interés que cubría un amplio espectro social.

Como sostiene con lucidez Renán Silva (1998) “el carácter minoritario de los grupos sociales afectados en principio por estas nuevas prácticas de la lectura, por las

\footnotetext{
${ }^{56}$ Efectivamente, las tertulias fueron espacios donde las mujeres tenían una participación destacada, ya sea como anfitrionas de las casas en donde se realizaban las reuniones o bien como asistentes. En el caso cubano, José Martí señala la presencia central de Loreto Castillo, esposa del Duque de Estrada, y de su hija, Herminia, en las tertulias organizadas en su residencia, espacio privilegiado por donde circularon los "poetas de la guerra". En este capítulo hacemos referencia a que este tipo de reuniones se desarrollaron en diversas ciudades de América Latina, por ejemplo, en Buenos Aires, fueron famosas las tertulias de Mariquita Sánchez de Thompson desarrolladas en las primeras décadas del siglo diecinueve. Ver Gálvez y Obligado 1977.
} 
formas de relación y de asociación que ellas suponían, no debe hacer perder de vista su novedad y significación” (Renán 1998: 81).

Pero, además, esas reuniones y asociaciones resultaron no sólo un vehículo para la circulación del nuevo libro y de nuevas prácticas de lectura, sino uno de los puntos centrales de formación de las prácticas sociales modernas respecto de la libre elección, la manifestación de juicios y la construcción de una opinión, todos estos elementos propios de un espacio público moderno.

En distintos lugares de América Latina surgen estas asociaciones ${ }^{57}$ que en líneas generales presentan las siguientes características: periodicidad en los encuentros, reglas que establecen y moderan el debate, la Ilustración recíproca de sus miembros. Y como ya se ha mencionado, conviven en esta práctica "novedosa" de la tertulia elementos tradicionales, pues como sostiene Renán a partir del análisis de este tipo de asociaciones en Nueva Granada "se trata de formas de encuentro de una gran movilidad y de rápidas transformaciones en cuanto a sus fines, sus orientaciones y,

\footnotetext{
${ }^{57}$ En el caso de Venezuela, la eclosión tertuliana se genera después de 1810. Por un lado, aparecen asociaciones privadas de carácter literario o científico, tales como los salones de lectura en el Café del Comercio de Caracas, el establecimiento de bibliotecas, entre otros, cuyo objetivo es la difusión de conocimientos útiles para el Estado. En esta línea se inscribe la Academia Militar de Matemáticas y de la Sociedad Patriótica de Agricultura y Economía. Por otro lado, aparecen sociedades o clubes de asociados para debatir sobre asuntos políticos. En ambos casos, la circulación de los periódicos impresos tuvo el papel decisivo. Entre las tertulias más conocidas se halla la de Galindo, quien para 1810 era teniente de granaderos del Batallón de Milicias de Blancos Patriotas. Otro grupo de breve existencia fue el "Club de los sin camisa" fundado en su propia casa por Andrés Moreno. Sin embargo, la más exitosa de todas las tertulias fue la Sociedad Patriótica fundada en Caracas, la cual nació con el fin de discutir y opinar sobre materias políticas y sus filiales, en el mismo orden, asumieron la función didáctica de "ser escuelas de patriotismo". Ver Leal Curiel (1998).

En Buenos Aires fue célebre el café del Marco — perteneciente a Pedro José Marcó, inaugurado en 1810, ubicado en la emblemática esquina de las calles San Carlos (Alsina) y Santísima Trinidad (Bolívar) a un paso del Cabildo y de la Plaza Mayor. Fue el espacio elegido por los jóvenes revolucionarios y la burguesía bohemia como centro de reunión y discusión hasta mediados del siglo diecinueve, cuando la fiebre amarilla obligó a quienes lo frecuentaban a mudarse a los barrios más altos de la ciudad.

Pero la tertulia de Buenos Aires con más renombre es la organizada en 1837 por Marcos Sastre, conocida como Salón Literario. En esas tertulias, los jóvenes influenciados por el Romanticismo discutían sobre literatura, cultura, arte y política. Entre los miembros más destacados que participaron del Salón se reconocen las figuras de Juan María Gutiérrez, Esteban Echevarría, Miguel Cané, Juan Bautista Alberdi y el propio Marcos Sastre, entre otros. Para una descripción general ver José Luis Romero (1983). Sobre las tertulias y las formas de sociabilidad ver Jorge Myers (2003) "Aquí nadie vive de las letras. Literatura e ideas desde el Salón Literario a la Organización Nacional" y el reciente libro de Paula Bruno (2014), Sociabilidades y vida cultural. Buenos Aires, 1860-1930.
} 
sobre todo, en cuanto a sus prácticas, en la medida en que la política moderna y el periodismo político van haciendo su irrupción” (Renán 1998: 89) ${ }^{58}$.

En América Latina algunas de estas "asociaciones del pensamiento" o académicas dependen de entes coloniales como la Sociedad Económica Amigos del País. Pero paradójicamente entre sus aspiraciones compartidas, a pesar de las distancias y las diferencias de origen, está la emancipación del mismo orden colonial. Por esa razón, muchos de estos espacios han sido considerados como centros conspiradores en los cuales se fabricaba la independencia.

En este sentido, es posible pensar las tertulias en tanto "instituciones para la utopía" pues combinaban en prácticas dispersas y difusas el emergente sentimiento de una clase criolla que buscaba legitimarse y, al mismo tiempo, diferenciarse. Es decir, las tertulias propiciaron la expresión del sector ilustrado y criollo que se proponía pensar la patria en términos de autonomía cultural y política.

Por otro lado, las tertulias también posibilitan la reflexión sobre la formación de la opinión pública, puesto que se generan como espacios legítimos de discusión y debate de temáticas de índole cultural, político-económica y social. En este sentido, son espacios que otorgan el marco para que comience a gestarse una sociedad de opinión y de libre examen, práctica que devendrá central para transformar a los miembros de la República de las Letras en hombres de la palabra y de la pluma (Renán 1998: 81).

En Cuba, las tertulias tienen su origen en 1834, cuando la Academia Cubana de Literatura fue disuelta. En ese momento, Del Monte fue el primero en hallar una solución, quizás la única posible. En Matanzas, a donde se había trasladado para ejercer la abogacía, comenzó a reunirse con sus amistades en el ambiente de una

\footnotetext{
${ }^{58}$ Entre las asociaciones a las que hace referencia el exhaustivo estudio de Renán respecto de las tertulias en Nueva Granada, se hallan: la "tertulia Eutropélica" de 1790, de Manuel del Socorro Rodríguez, las actividades de lectura en el Observatorio Astronómico impulsadas por Francisco José de Caldas, la "sociedad de Literatos de Santa Fe" que funcionó en la casa del imprentero Antonio Nariño, la "tertulia literaria" de la ciudad de Cartagena (1811-1812). Es de notar también que en SantaFé, María Manuela Santamaría Ricaurte funda en 1801, la "tertulia del buen gusto", generando un nuevo espacio de sociabilidad pues funde en un único espacio, los ambientes dedicados en la casa al género masculino $\mathrm{y}$ al femenino respectivamente. También son interesantes las descripciones del ambiente de las tertulias que ofrece Patricia Lara Betancourt (2001) en su artículo "La sala doméstica en Santafé de Bogotá silo XIX, el decorado: la sala barroca".
} 
discreta intimidad doméstica para discutir lecturas, analizar obras escritas y tratar asuntos políticos y sociales que resultaban imposibles de comentar en público. Como sostiene Andioc Torres (2002) en el estudio introductorio del segundo volumen del Centón espistolario de Domingo del Monte:

Sus amigos de entonces configuran un grupo social claramente delimitado. Está formado por un sector de la joven generación de hacendados azucareros caracterizado por su cultura y por no formar parte de los "productores históricos"; son los hijos de comerciantes españoles devenidos hacendados que tienen su centro de enriquecimiento en la provincia matancera. Otro aspecto de diferenciación con los "productores históricos" es su concepción de la gestión económica tendiente a la descentralización y liberalización de la economía. Algunos de ellos son esclavistas vergonzantes en tanto, por su cultura y adhesión al pensamiento liberal moderno, no pueden admitir la institución esclavista, pero por la propia estructura productiva cubana y la escasez de mano de obra se ven precisados a utilizar ese tipo de fuerza (XIII).

Dos años después, en 1836, de regreso en La Habana, continuó esa labor en su casa, situada en la calle homónima, casi esquina a Muralla, donde se reunía lo más prometedor de la juventud intelectual de entonces: Manuel y José Zacarías González del Valle, José Antonio Echeverría, Rafael Matamoros, José Silverio Jorrín, Ramón de Palma, Cirilo Villaverde, Felipe Poey, Anselmo Suárez y Romero, y, ocasionalmente, huéspedes suyos como Félix Tanco, los hermanos José Jacinto y Federico Milanés, Gaspar Betancourt Cisneros y otros.

Con respecto a cómo se desarrollaban estas tertulias, los biógrafos de Del Monte señalan que no es posible reconstruir la lista completa de las personas que de una $\mathrm{u}$ otra forma asistieron a esas reuniones ${ }^{59}$. Aunque se sabe que además de las nombradas participaron de las tertulias Anacleto Bermúdez, José María Cárdenas y Rodríguez, Gabriel Plácido de la Concepción Valdés, Ramón Zambrana, José Victoriano Betancourt y el Conde de Pozos Dulces, entre otros.

\footnotetext{
${ }^{59} \mathrm{Al}$ respecto, Federico Milanés ofrece en el "Prólogo" a la segunda edición de las Obras completas de su hermano José Jacinto (1865), un exhaustivo detalle de la sociabilidad literaria en torno a Domingo del Monte y sus tertulias.
} 
En cuanto al ambiente donde se desarrollaban las reuniones, Andioc Torres recuperando el artículo de Blanchet (1912) expone:

En el amplio local de la sala del palacio de Aldama donde se reunían los contertulios, en una de cuyas paredes se desplegaba un extenso mapa de la Isla de Cuba mientras que en otras veíanse estampas curiosas, se exhibían en ellas dos estantes repletos de libros a los cuales todos tenían acceso y, esparcidos por el diván y su bufete, podían hallarse diarios y folletos de interés cultural y literario. Cada día se encontraban allí personas amantes de la literatura o con inquietudes sociales y culturales. Poco a poco se iban formando pequeños grupos que se replegaban hacia distintos rincones de la sala donde desarrollaban sus conversaciones según los temas a los cuales eran afines. En otras ocasiones, del Monte llamaba la atención de todos los concurrentes para que escucharan algún texto que deseaba dar a conocer. De voz agradable, con excelente dicción y ademanes adecuados, leía fragmentos de un valioso libro o de un nuevo escrito. Terminada la lectura, incitaba a discutir la calidad de la obra y el tema en ella tratado. No pocas veces provocaba la discusión sobre los vicios de Cuba, la necesidad de reformar o cambiar el sistema de explotación esclavista, sobre la situación política de la Isla o sobre el Romanticismo o las últimas tendencias filosóficas. Era conocida la especial forma de mantener su opinión que siempre daba la impresión de una extraña combinación de firmeza y decoro. En otras ocasiones, el grupo se animaba para escuchar el trabajo de un contertulio o, ¿por qué no?, de un extraño que por primera vez era invitado a leer su trabajo. Por lo general y para mantener sin conflicto las reuniones, las intervenciones procuraban tener un tono imparcial y cortés; era costumbre esperar a que del Monte pronunciara su fallo definitivo (XXI).

Las tertulias de Del Monte producen un efecto replicador en sus coetáneos. En este sentido, las tertulias se constituyen en ámbitos de encuentro en los cuales se propicia el intercambio de libros y lecturas. La voluminosa correspondencia de Domingo del Monte es un muestrario del circuito de libros que gracias a estas prácticas de lecturas se socializan y difunden. En una carta que le escribe José Jacinto Milanés en 1838, le expresa a Domingo del Monte:

La reunión de amigos que cada miércoles y sábado nos juntamos en casa de Pedro Guiteras a leer y discutir sobre asuntos puramente literarios, desea 
empezar con la lectura de la María una especie de estudio sobre las costumbres o instituciones políticas de los Estados de Unidos, y sabiendo que V. se prestará a proporcionarnos dha obra, me encarga que se le pida en nombre de todos, con la súplica de que nos la remita $\mathrm{V}$. por el más pronto conducto (Centón 147).

Varios amigos nos reunimos algunos días a la semana con objeto de leer obras provechosas. Actualmente tenemos entre manos el proyecto de leer algunos libros que nos instruyeran de las cosas de los E.U a cuyo efecto pensamos empezar con la María para continuar en seguida con Tocqueville, Chevalier y la Historia de la Guerra Americana por Botta. Carta enviada por Juan Padrines — fechada 14 de febrero de 1838 (Centón 144).

En carta que le escribe José del Castillo, también en 1838, éste le dice:

No puedo olvidar el deseo que Palma manifestó de leer a Cousin en reunión de amigos. Alimente V. ese deseo y estimule esas reuniones lo que asi se lee se aprovecha todo, se lo asimila uno mas, porque las observaciones que sobre lo que se lee hacen los concurrentes hacen el efecto de rumiar los alimentos $-\mathrm{y}$ además el aliciente a la atención de que se oye o de lo que se lee hace de la presencia de otro que atiende también. Esta idea es de Bacon, y es la que desde su tiempo popularizo el Ing. Y Escosia el gusto a los clubs literarios, que tanto bien han hecho a esa nación.

Insista V. en que Palma le coja el gusto al Inglés, esos hombres son mas griegos y romanos, sean ellos nuestros modelos- Para el hombre el ejemplo es media tarea hecha: dimidium facti

Aquí mi tiene V. en esta soledad y manejando esclavos-y en trabajos de ingenio, y ingenio viejo- Sin embargo, aquí están Sócrates y Moyses y San Pablo y Dugald Stewaert conmigo... (Centón 279).

Estos párrafos transcriptos son, a nuestro criterio, relevantes porque condensan elementos que definen prácticas de lecturas llevadas a cabo en las reuniones literarias.

En primer lugar, se aprecia la valoración positiva de la lectura colectiva. Esta construcción se realiza mediante la utilización de términos que ligan la lectura a las 
metáforas alimenticias ${ }^{60}$. En este sentido, se recuperan una serie de palabras que elaboran un campo semántico de la lectura como alimento: asimilación, provecho, rumiar. La asimilación — esto es la incorporación del texto- se torna nutritiva si es que de la lectura se saca algún provecho. En tanto que la idea de "rumiar" conlleva a asumir la reflexión necesaria a la que invita la práctica de lectura junto a otros. Como sostienen los teóricos que han revisado las prácticas de lectura occidentales (CavalloChartier 1998; Frenk 2005; Manguel 2005) las metáforas sobre la alimentación aluden a dos planos: uno fisiológico y otro por el cual intentan definir la asimilación con el proceso mental llevado a cabo por el lector. Estos dos usos metafóricos entran en contacto en el concepto de la ruminatio. Si bien esta noción se remonta a la Edad Media, donde probablemente aludía “al murmullo del monje que leía mascullando las palabras en voz baja" también servía para denominar simultáneamente el ejercicio de asimilación y meditación que llevaban a cabo los monjes sobre la Biblia (Hamesse 2001).

Por otro lado, la carta revela dos aspectos no menores. El primero de ellos es la comparación que establece Castillo con Escocia, en la cual se repara respecto de cómo los clubes literarios han hecho "tanto bien" a esa nación. Y en relación a esta estrategia, el requerimiento de aprender el idioma inglés, para poder leer las obras en su idioma original. Esta búsqueda de modelos culturales es una constante para Del Monte y sus coetáneos. Como sostiene Dávila (2005) podría pensarse que el reclamo de modernidad que impulsaba profundamente las acciones de los letrados como Domingo del Monte hacía que estos hombres mirasen las luces europeas al mismo tiempo que desdeñaban los lazos políticos que mantenían con la metrópoli. Esta

\footnotetext{
${ }^{60}$ Iveta Nakladalova (2005) aborda con precisión las metáforas de la lectura en el Siglo de Oro español. Ella recupera la metáfora de Séneca en su Epistulae morales, la cual refiere a las abejas que revolotean entre las flores para tomar el mejor polen para fabricar la miel. Si bien, la metáfora de Séneca ilustra el proceso de imitación literaria, en el Renacimiento se recuperan estas imágenes clásicas y se reelaboran por lo que Nakladalova sostiene que hay un gran número de metáforas relacionadas con la lectura, porque la lectura "parece tener un carácter que se escapa a descripciones directas". En cuanto a las metáforas que ligan la lectura a los procesos de la alimentación y la digestión, observa que al trasladar las acciones del cuerpo a las acciones del espíritu este grupo metafórico se comporta de la misma manera que la mayoría de las metáforas renacentistas sobre la lectura. En primer término, pretenden captar el proceso de la ingestión y adaptación de una materia ajena al cuerpo del lector. En este sentido, las metáforas se insertan en diversos contextos, que van desde la idea de consumir un texto a la idea de asimilación, entendida como la apropiación del significado semántico del texto por parte del lector. De este modo, la lectura pasa de ser cuerpo ajeno a ser cuerpo propio.
} 
"modernidad fragmentada" que busca lo "nuevo en lo viejo", lo "americano en lo europeo" no es más que el efecto estrábico ${ }^{61}$ de un proyecto racionalizador llevado a cabo por las elites criollas.

El segundo aspecto a notar guarda relación con el contexto. Como ya hemos referido, en Cuba, el pensamiento ilustrado se ve envuelto en una paradoja, pues la vindicación que los hombres de letras hacen de los derechos de libertad, igualdad y justicia choca con el sistema esclavista, sobre el cual se asienta y organiza el esquema sociocultural cubano. En el final de la carta, Castillo pone de manifiesto el estado contradictorio en el cual se halla y configura una escena de lectura en que conviven el ingenio y los esclavos con sus autores preferidos. No es menor la aclaración que le hace a Del Monte "y ingenio viejo". En esta denominación operan en el mismo nivel la elipsis y la referencia, pues en este decir sin decir, el emisor le está dando a entender a Del Monte que su trabajo es mucho más difícil y arduo, ya que la estructura y organización del ingenio viejo resiste por la perduración de prácticas esclavistas muy duras.

Este aspecto que la carta en cuestión nos revela permite pensar que el intercambio epistolar, tan abigarrado en este periodo, contribuye a reforzar las redes sociales que integran a los miembros de una comunidad o grupo selecto. De este modo, las cartas se convierten en un cuerpo de socialización que vehiculiza distintos intereses, distintos géneros y sobre todo, permite la circulación de ciertos ideales ilustrados que se incorporan paulatinamente a la propia vida personal. Al respecto, en los epistolarios epocales se advierten dos características singulares. Por un lado, el uso de un lenguaje compartido que refiere la idea de un tiempo histórico continuo, de un movimiento que conduce a las sociedades hacia el progreso, tiempo al cual debe sumarse la acción del hombre para acelerarlo, en este sentido, observamos las múltiples referencias a los avances técnicos, a la novedad, al progreso como temáticas que atraviesa la producción discursiva del periodo. Y por otro, notamos un deseo de acercar los "libros a la vida"

\footnotetext{
${ }^{61}$ Ricardo Piglia, en "Sarmiento escritor" retoma la síntesis de Echeverría que sentencia "Hay que tener un ojo puesto en la literatura francesa y otro clavado en las entrañas de la patria" para definir este concepto de la "mirada estrábica" que caracteriza a los letrados del siglo diecinueve y que, según Piglia, "funda una verdadera tradición nacional, una relación de alianza y de diferencia con otras prácticas, otras lenguas y otras tradiciones" (1998: 22).
} 
(Renán 1998: 98), de volver reales estas concepciones ilustradas que comenzaban a ser apropiadas por estos letrados.

En este sentido, el fragmento reproducido de la carta de Castillo no es el único en el cual se advierten estos rasgos.

Revisemos, al respecto, la carta que le escribe J.B. Sagarra a Domingo del Monte en 1839:

Mi estimado amigo: lea V. y luego hablaremos me dijo V. al enviarme la excelente obra de filosofía de Mr. Cousin. He comenzado a leer y ya deseo, con tanta mayor razón cuanto que el aislamiento en que vivimos en Cuba, me hace mas apetecible esta comunicación de ideas. Faltamos aquí comerciantes de esta preciosa mercancía porque han faltado depósitos que las suministren y propaguen, y nos impongan la costumbre y la necesidad de consumirlas. Veo la necesidad que de ellos tenemos y deseo remediarla, aunque corra nuevos riesgos; que algo debe arriesgarse en favor de la gran causa del saber.

El tema central de la carta se expone en este primer párrafo: el conocimiento y su difusión. En relación a esto se configuran ciertas imágenes que ligan "saber" a "mercancía". El conocimiento al cual se accede por la lectura aparece como una "carencia" en el "aislamiento" cubano. Los campos semánticos a partir de los cuales se elaboran estas nociones en torno al saber en tanto "comunicación de ideas" deja al descubierto cómo los ideales de la Ilustración impregnan el intercambio entre los letrados. Sin embargo, esta necesidad puede remediarse. En ese lugar intersticio opera la figura del letrado, quien intermedia entre el saber y los "ignorantes"62. Expresa el autor de la carta: “El obstáculo más poderoso están en mi insuficiencia pero ahí están V. y Luz que me ausiliarán desde allí”.

\footnotetext{
${ }^{62}$ Es necesario recordar que lejos de unificar al pueblo, los nuevos valores, el surgimiento de la opinión y de sociabilidades modernas constituyen una nueva jerarquía. Esta ya no descansa en el nacimiento o la pertenencia a cuerpos o estamentos privilegiados sino en el capital cultural. El acceso a los impresos, a la lectura individual, a la opinión de los "sabios" y a la información política produce una profunda división entre el público, del cual se excluye a la mayoría considerada como "ignorante". En estos términos, "ignorancia" se denomina a la fidelidad del pueblo a sus modalidades tradicionales, orales, y costumbres: costumbres heredadas del Antiguo Régimen que en realidad remiten a los derechos y a los ceremoniales propios de la organización corporativa y que el concepto moderno y abstracto de ley no puede reconocer como legítimos.
} 
En cuanto a la presentación del saber, la carta continúa con un apartado en el cual se elogia la organización y la presentación de la teoría de Cousin, lo cual pone en evidencia la estimación de la racionalidad en la construcción de las teorías filosóficas:

He leído la $1^{\circ}$ lección, en la cual ya se tropiesan con ideas nuevas, al menos para mí. Y no solo nuevas, sino presentadas en un orden verdaderamente analítico, orden que solo puede seguir, quien ha llegado a enseñorarse de esa ciencia y de que se tiene un claro indicio con solo ver la tabla analítica que precede a la obra (Centón 308-309).

Un intercambio particularmente interesante en el cual también pueden explorarse estas marcas de la Ilustración es el que mantienen Domingo del Monte y Gaspar Betancourt Cisneros, apodado "El Lugareño". En la correspondencia se advierte el contraste cultural entre La Habana y Camagüey. En este sentido, esta textualidad vitaliza las tensiones entre la ciudad y los otros pueblos, considerados por los hombres ilustrados como más “atrasados” en la carrera de la civilización.

"El lugareño", apodo más que singular para expresar el apego y la identificación a la tierra, expresa frente a las palabras descalificantes de Del Monte:

Lo que más ha molesta es que la especie de los bachilleres y litigantes han venido á civilizarnos. Aquí tomo yo parte, voto a Bríos! Y la tomo a fuerza de Camagüeyano. La Civilización es un sol, camarada, que brilla para todo el mundo: es el siglo que está haciendo su viage redondo por la tierra: es un terremoto cuyo combustible está en la gran Cordillera de America, en el Alleganny, se inflama, estalla y su sacudimiento se siente en todos los puntos de la America. Unos participarán mas que otros: esto es natural; pero los Señores Bachilleres y litigantes no traen aquí mas que pomadas, travillas y la mayor parte fruslerías é insustancialidades lechuguinas de que abunda la Habana mas que el Camagüey (Centón 282).

En el fragmento anterior hallamos una definición de "civilización" que se elabora con la metáfora del "sol que brilla para todo el mundo". La luz del conocimiento es, desde la perspectiva del Lugareño, "natural"63. La comprensión de pertenecer a una época, a

${ }^{63}$ Sin intenciones de establecer relaciones anacrónicas, pues el periodo que nos ocupa es anterior, resulta
casi imposible, si reparamos en la configuración del imaginario nacional cubano, no traer a colación las
palabras de José Martí cuando en su célebre ensayo "Nuestra América" (1891) refiere a la artificialidad
de los letrados que "reniegan del delantal indio de la madre que los crió". En ese ensayo, Martí instala en
la matriz de la identidad cubana otro binomio "falsa erudición/naturaleza" que desplaza al de 
un siglo de cambios vertiginosos se elabora con otras metáforas: combustible que estalla e inflama todos los puntos.

Por otro lado, los bachilleres no llevan a Camagüey "luces" sino "fruslerías e insustancialidades". Si bien la carta tiene un tono jocoso compuesto por la elección de las palabras y el registro informal, pone en evidencia las tensiones respecto de la idea de "civilización". En este sentido, para Del Monte la civilización guarda relación estrecha con poseer un bagaje cultural de signo europeo (de donde toma modelos literarios y de civilidad que intenta promover en Cuba). Betancourt Cisneros responde a las críticas de Del Monte a partir de lo que conoce. Su conocimiento de Camagüey como lugareño le permite retrucar las palabras de Del Monte.

Sepa usted que aquí hay virtudes muy sobresalientes, y algunas muy peculiares del Camagüey. Yo no trueco los miserables Camagüeyanos (y son sin cuento) por los botarates dilapidadores que hay por allá; ni los humildísimos demócratas que componen casi todo este pueblo, por la altanera aristocracia de la Habana. Verdad es que todo esto lo trae la nuestra pobreza: aquí no hay en qué dilapidar, ni hay títulos ni rancias noblezas en que fundar la insolente vanidad de los grandes; pero ahora no tratamos de las causas sino del efecto, del hecho cual ecsiste. Mis camagüeyanos en general son unos materiales muy rústicos, es verdad, pero muy sólidos, con los cuales se pueden hacer muchas cosas buenas: en este pueblo se necesita fundar, crear: en aquel se necesita derribar, reformar: aquí es preciso aprender: allí desaprender ¿me entiende V.? (Centón 283).

Sin embargo, otras voces se suman a esta discordia. Tal es el caso de Rafael Matamoros, quien en carta fechada en diciembre de 1838, desde Camagüey, dice:

En la $3^{\circ}$ entrega del Plantel he visto el artículo de V. sobre el movimiento intelectual en este pueblo, artículo que se ha publicado en la Gaceta; y en un Diario de la Habana he leído el de un principeño, inserto también aquí en otro Gaceta. Han recibido estos menguados del Camagüey con sumo descontento el

“civilización/barbarie". Por ello llama "criollo exótico" al letrado artificial, de "libro importado", a aquel que no conoce el "pueblo natural" y por lo tanto, no podrá nunca ser un "buen gobernante". La metáfora de las luces empleada para describir tanto el periodo como a los hombres de la Ilustración es retomada por Martí pero en tono invertido, así en el segundo párrafo del ensayo hace referencia a "ya no podemos ser el pueblo de hojas (...) restallando o zumbando, según la acaricie el capricho de la luz" y en el último párrafo cuando define a estos "pedantes vencidos" como "pensadores de lámparas, que enhebran y recalientan las razas de librería” (1991: 15-23). 
tal artículo de V. dicen que es V. un petate que habla a tontas y a locas, $\mathrm{y}$ según tengo entendido ha de publicarse otro artículo en contestación a las observaciones de V. (...) Juzgo preciso que entre yo en la lid ya como amigo de V. y ya como amigo de que se destierre ese miserable espíritu de provincia, que tan profundas raíces tiene en este feísimo y atrasado pueblo (Centón 277).

En síntesis, para Del Monte Cuba está en el camino de la civilización, pero aún tiene carencias que es necesario remediar. Por eso, insiste con la educación para niños y niñas blancos y de color y con una literatura de índole moral que permita a los ignorantes y atrasados salir de ese estado. Pero la civilización está en Europa, por eso Pedro José Guiteras en una carta que le escribe a Del Monte (Matanzas, 20 de septiembre de 1838) le expresa que están realizando una colecta para que José Jacinto Milanés pueda viajar a Europa y "formarse allí con el trato de los ombres de pro i buen órden de estudios". La idea es que Milanés viva en Europa 4 ó 5 años “que es lo menos que deberá permanecer allí si queremos legar a esta pobre Cuba una cabeza bien

orgazanida: i como buenos ijos acudimos a los papas habaneros para que saquen provecho del orgullo nobilísimo de la clase ilustrada y de la vanidad aristocrática i vean si a nuestras 100 onzas agregan 150 ó 200 mas i conseguimos nuestro objeto (Centón 233).

Aunque, como bien señalan Guerra y Lempérière (1998: 97) es muy difícil saber cuáles fueron los efectos que este tipo de lectura compartida de libros e intercambio de correspondencia generó en quienes la practicaban, entendemos que sí es válido y posible rastrear en las cartas aspectos ligados a la conformación de circuitos de lectura, el ejercicio de la crítica literaria, la circulación de borradores de obras, el empleo de distintos idiomas para la comunicación, entre otros, que posibilitan configurar los rasgos de la sociabilidad literaria cubana en el siglo diecinueve.

En el próximo apartado, profundizaremos sobre las prácticas de lectura llevadas a cabo en el marco de estas tertulias.

\subsubsection{La crítica y la traducción como prácticas de lectura en las tertulias de Domingo del Monte}

Dos actividades intelectuales por excelencia son las que se propiciaron desde las tertulias organizadas por Domingo del Monte. La primera de ellas es la lectura crítica, 
que impuesta como metodología de los encuentros incitaba a quienes participaban de las reuniones a emitir una opinión sobre los textos leídos. Domingo del Monte es para los jóvenes literatos que se reúnen en su casa un "verdadero patriarca del buen gusto", con estas palabras se expresa José Zacarías González del Valle al respecto. El trabajo crítico al que motivaba permanentemente Del Monte iba acompañado de un proceso arduo de correcciones e indicaciones que en carácter de maestro daba a sus contertulios, tal como deja constancia Anselmo Suárez y Romero, en 1838, en el prólogo que escribe a las obras de Ramón de Palma:

Cada cual leía la obra que había escrito, leíase en presencia de unos cuantos amigos, introducíase en ella las correcciones convenidas, llevábase a la prensa y tornaba después a examinarla muchas veces en la repetición de aquellas gratas conferencias" (Bueno 1979: 35).

En segundo lugar, pero ligado estrechamente a este proceso de lectura del "buen gusto", se halla la labor de traducción (Arencibia Rodríguez 1996-1997; 2004). Por Domingo del Monte, los poetas y escritores que participan de las tertulias conocen y leen a Víctor Hugo y a Balzac, a Walter Scott y a Goethe. Además vuelcan su interés en los clásicos españoles, como Lope de Vega por el valor popular que tienen sus obras.

En su afán por constituir una tradición literaria propia, Domingo del Monte propone fórmulas y modelos genéricos a los cuales busca adaptar e incorporar el tratamiento de asuntos americanos. De ahí su interés por Balzac, pues para él es un modelo de realismo, como la relevancia que atribuye a Scott por el modelo que ofrece de novela histórica. En este sentido, recupera el romance español como un género que considera valioso a los efectos de configurar un parnaso nacional. Al mismo tiempo que defiende este tipo de expresiones y géneros, rechaza el Romanticismo, en la representación de ciertos autores europeos por considerarlos individualistas, asociales y reaccionarios. Por esta razón, censura a Lamartine, a Lord Byron, a Alfredo de Vigny, a Jorge Sand.

Según Salvador Bueno, quien ha abordado con detalle este periodo en $L a$ crítica literaria cubana del siglo XIX, Domingo del Monte no piensa en la formación de una literatura nacional, pero sí la quiere criolla y americana. "No parece —insiste el autor- que hubiera sido partidario de la total autonomía de las letras de nuestro 
continente, ya que consideraba que el vínculo idiomático mantendría a las literaturas de las antiguas colonias integradas dentro de la general literatura española” (Bueno 1979: 38).

Como ya se ha expresado en el desarrollo de estas páginas, Del Monte reconoce la maternidad de la lengua española y en ese sentido, el vínculo inexorable que Cuba tiene con España. Sobre esta convicción, en el estudio que Del Monte realiza sobre “Caracteres de la literatura española", advierte: "Otros países que aunque no forman comunión política con España no dejan de ser españoles y lo serán por decreto irrevocable de su destino mientras hablen la lengua española" (Bueno 1979: 38). Por esa razón, a los contertulios más jóvenes y corresponsales les insistía en la necesidad de leer a los grandes autores, sobre todo a los clásicos españoles para poder escribir a tono con el espíritu del mismo idioma.

En una carta que Del Monte le escribe a Gonzalo Alfonso en 1826, expresa:

Se me olvidaba recomendarte mucho el estudio de los antiguos poetas españoles, como Garcilaso, Herrera, Rioja, etcétera; porque, hijo mío, los modernos, excepto Moratín y Lista, todo lo tendrían menos pureza de lengua. Huye siempre del neologismo o introducción de palabras nuevas o exóticas; no imites nunca la desgraciada sintaxis del apasionado y fogoso Cienfuegos, ni del filósofo Quintana, ni de uno que otro de éstos que andan de moda. No los leas mucho que son pegadizos sus defectos. Si quieres pensamiento, estudia las ciencias del hombre, es decir, la moral, la política y la física, y para aprender la verdadera, armoniosísima lengua castellana bebe en las cristalinas fuentes que te he indicado. Si sigues estos consejos, producto de una experiencia observadora, serás, ¡oh, hijo mío en Apolo! la delicia del mundo, el regocijo de las musas y la gloria de tu maestro (Bueno 1979: 41).

La crítica ejercida por Del Monte sobre las producciones que recibía se ampara en estos postulados estéticos. En el epistolario que mantiene con jóvenes escritores como Juan Padrines, o los hermanos Federico y José Jacinto Milanés se advierte cómo éstos configuran su autoridad, concibiéndolo como una especie de tutor y cómo influye la mirada de Del Monte en las obras que escriben. El efecto correctivo también se expone en pasajes de la correspondencia privada:

En carta fechada el $1^{\circ}$ de septiembre de 1838 , le dice José Jacinto Milanés: 
Mi apreciable y querido Delmonte.

Ahí va la obra dramática de mi hermano Federico "la

Cena de D. Enrique el Doliente" para que V. y demás amigos la lean y examinen. El plan que su autor ha adoptado me parece el mas conducente a pintar bajo un punto de vista dilatado la época de D. Enrique $3^{\circ}$. El rey, los grandes y el pueblo son los tres elementos de este drama para hacerlo interesante bastaba la lucha del rey con los grandes, pero era preciso hacerlo moral y para esto presenta al pueblo como un tercero en discordia dotado de mas derechos que ambos contendentes y esperándolo y temiendolo todo del écsito de la lucha (Centón 223).

Sobre el final de la carta, le dice: Federico y yo esperamos ansiosos el dictamen de V. y demás amigos".

En la cita se advierte cómo el intercambio epistolar es al mismo tiempo el canal por el que circulan borradores y obras en producción. En este caso, las palabras de José Jacinto Milanés exponen el mecanismo de lectura compartida, pues el texto se presenta a Domingo del Monte y por intermedio de éste a otros amigos. El juicio, la valoración sobre el texto que el grupo realice se convierte en dictamen para los jóvenes escritores.

El propio Federico Milanés le refiere a Del Monte en otra carta con idéntica fecha:

Mi estimado Sor: á la bondad de V. recurro con ese mi primer ensayo dramático, para que V. se tome el trabajo de ecsaminarlo y en su consecuencia opine sobre lo que piensa de él, pues aunque el Sr. De Tanco, Oses y varios de mis amigos no le ponen reparo, con todo deseoso de no hacer correr una mala suerte á esa obra, la someto a su fallo seguro de que V. me dirá francamente si merece ó no la luz pública... Tenga V. la bondad de decir á los amigos Echeverria, Matamoros \& compañía que no me dejen de dar su opinión de jueces desapasionados (Centón 224).

Sin embargo, pese a exponer el drama en cuestión para que Del Monte y otros lo examinen, cuando este grupo de lectores da su parecer, como respuesta José Jacinto Milanés escribe una extensa misiva en la cual defiende la obra de su hermano y aclara, rectifica y corrige las opiniones que Echeverría, Valle y Matamoros han vertido sobre la obra. 
Algunos elementos de esta epístola son interesantes de relevar para analizar el funcionamiento de escenas de lecturas ligadas al ejercicio de la crítica literaria.

En primer lugar, la carta guarda un tono de defensa que se corresponde con las nociones de "fallo", "juicio", "dictamen", "veredicto" que marcan el registro empleado por los hermanos Milanés al solicitar la lectura del drama. Este tono de defensa se construye en el primer párrafo de la carta, en el cual se expone el tema central:

Cumpliendo pues la oferta que hice en mi anterior de responder a los cargos que esos Sres Valle, Echeverría y Matamoros han puesto al drama de mi hermano, ruego a $\mathrm{V}$. tenga la bondad de leer las siguientes líneas y enseñarlas a dos amigos cuando estos le vean (Centón 239).

En este inicio, J. J. Milanés se propone "responder a los cargos" pero al mismo tiempo se devela otro procedimiento de lectura que escapa al acto privado que caracteriza el intercambio epistolar. Pues solicita a su destinatario que le lea la carta a los otros señores del grupo. Por lo que en principio se modifica la función de comunicación íntima y privada propia de la carta y ésta pasa a convertirse en texto socializado. Por ende, el destinatario también se modifica y se extiende al grupo selecto de lectores que han criticado la obra.

El cuerpo de la carta se convierte, entonces, en un espacio polifónico donde conviven las palabras de José Jacinto Milanés, las de su hermano Federico y las opiniones del selecto grupo de lectores, más las palabras de Domingo del Monte. La pluralidad de voces se construye mediante la estrategia de citas directas e indirectas. De este modo, las explicaciones y excusas que devienen en extensos párrafos donde el emisor expone ciertos saberes literarios se articulan en preguntas que Milanés se hace y hace a Del Monte y a los otros destinatarios. Con el juego de las preguntas (algunas de ellas retóricas) intenta confrontar pero manteniendo siempre una actitud modesta pues sabe que no está a la altura intelectual de sus destinatarios (real y diferidos).

Bien echa de ver mi hermano que el grado de interés de su obra no es el de la primera magnitud, pero sí cree, y yo con él, que le plan que ha seguido no solo ha de sostenerse en el teatro, pero debe agradar y atraerse el interés de un modo inequívoco. Allá se opina que no, y acá que sí. Quién decide esta 
cuestión? El teatro, porque efectivamente mi hermano no hizo el drama para solo leerse, hízolo con la intención de representarse y ya que la crítica ha descargado su fallo, es preciso apelar al de las tablas, el cual, agradeciendo á la crítica su buen deseo de ilustrar, es el último y la que debemos atenernos. Dice V. que opinan esos Sres. que el marco en que ha colocado sus escenas es también de proporciones reducidas y pequeñas. ¡Proporciones reducidas y pequeñas las de un drama en que se pinta bajo un triple aspecto una época antigua! Añada V. que parece a esos Sres la repartición del todo de la acción en dos actos desproporcionada y fatigosa. Este reparo tendrá mucha fuerza cuando se apoye en razones esplicativas que no dejen la menor duda, pero mientras venga solo y pelado, no es posible que nos convenza (Centón 239).

La carta se organiza en función de los aspectos que los críticos han juzgado de manera negativa. Los elementos analizados y los argumentos para la evaluación realizada son recuperados por Milanés y refutados. En este sentido, la carta opera no solo como respuesta sino al mismo tiempo como ensayo crítico, pues en la elaboración de la respuesta intervienen tanto los saberes literarios de Milanés como su experiencia como espectador / lector / escritor.

En relación a los temas por los que discurre la carta, la preocupación por el tono y el lenguaje es central ${ }^{64}$.

Vengamos ahora al estilo. Son de parecer esos Sres que el estilo del drama deja ver cierto amaneramiento de la escuela romántico-moderna española, pero yo no doy á verdad con el tal amaneramiento. Lo que hallo es una frase natural y tan castiza que todo el lenguaje del drama pudiera haberse escrito en el siglo $17 \mathrm{y}$ si no, señáleme V. una sola dicción, un modismo solo que no fuese correcto en

\footnotetext{
${ }^{64}$ Un análisis revelador sobre este tema es desarrollado por Graciela Salto (2012) en el capítulo "Nuevos tonos de antiguas voces cubanas: actualizaciones de la memoria oral" de Ínsulas y poéticas. Figuraciones literarias en el Caribe. En él, Salto analiza el núcleo de la oralidad y la memoria en Cuba a partir de considerar como acontecimientos discursivos las actualizaciones de la memoria oral del siglo diecinueve (voces, modos de hablar, repertorios de gestos y tonos). Salto advierte que la actualización y resignificación de "antiguas voces cubanas" permite explicar la escena literaria y cultural contemporánea. Los "tonos" (el "sencillo" de Milanés, los matices "semi-andaluces" de José María Heredia, las voces guajiras de Cirilo Villaverde, los tonos inadecuados" de Plácido) que se reactualizan en diferentes momentos históricos ponen de manifiesto el complejo entramado de relaciones entre poética, lengua y política. La noción de "archivo" le permite a Salto instalar una serie de reflexiones en torno a las genealogías literarias que proyectadas desde la imposición de la letra escrita entran en tensión con el universo de la voz. En este sentido, las actualizaciones funcionan como fisuras de los relatos de las literaturas nacionales que desbaratan la certeza del archivo.
} 
tiempo de Calderon. Eso que llaman esos Sres bajza y laxitud me atrevo a calificarlo de sencillez e ingenuidad de espresio, porque acáno creemos que haya estilo plebeyo ú aristocrático: lo bajo ó noble de un decir creo que consiste en la idea y no en la espresion (...) Nunca olvidemos que lo único en que no debeconceder libertades abusivas la bien ordenanda crítica al ingenio es en el fin moral de la obra: pero en cuanto a las formas con que se presente esta misma idea moral, por qué se ha de poner trabas al espíritu humano, que es tan libre de suyo (Centón 240).

Esta preocupación literaria y lingüística revela una conciencia histórica definida por la búsqueda de un lenguaje y de una forma singular que permita la expresión de la identidad en términos diferenciadores. Para Del Monte los modelos de creación hay que buscarlos en la España del Siglo de Oro y en algunos escritores franceses e ingleses. De ahí que insista en el romance como forma genérica más adecuada para expresar el sentir patrio. No obstante, la forma estética que debería adoptar la expresión literaria cubana genera en los letrados debates y tensiones. En este panorama de incertidumbres, Domingo del Monte ofrece respuestas y consignas de interpretación que permiten situar su discurso respecto de las influencias de las corrientes neoclásica y romántica en las producciones literarias decimonónicas.

Como señalamos, la traducción es otra de las actividades centrales llevadas a cabo por Del Monte y el grupo de escritores con los cuales intercambia libros y pareceres literarios. En este sentido, su labor como divulgador tiene como fin ofrecer a los escritores más jóvenes aquellas obras que Del Monte consideraba eran modelos de valiosas literaturas.

En el epistolario personal se advierten cuantiosos pasajes en los cuales se hace referencia a la práctica de traducción como una tarea frecuente. Pero la traducción en tanto trabajo intelectual corrobora instancias particulares de producción, circulación y difusión de los textos. Por un lado, deja al descubierto la red de intercambio de obras entre los escritores, pues no todos tenían el mismo acceso a los libros importados. En el caso de Domingo del Monte, sus amistades con escritores de otras latitudes y el poder económico que ostenta le permiten poseer una biblioteca permanentemente solicitada. Su correspondencia es ejemplo de un tráfico de libros incesante. 
La circulación de libros ofrece, además, un panorama de los intereses de lectura que distinguen al grupo delmontino y que se hallan relacionados con los avances tecnológicos, con el progreso y con la medicina. En el siguiente pasaje (respuesta enviada desde París el 3 de julio de 1838) es interesante reparar en la temática de los libros que Domingo del Monte le solicita a su hermano Pepe, la cual da cuenta de la demanda de lo "último" en diversas materias:

En cuanto a obras sobre caminos de hierro no te mando mas que dos pero una traducida del inglés, que aquí se ha escrito muy poco de la materia. Vá un $n^{\circ}$ del Moniteur en que se publicó el informe de Mr...que encontrarás muy luminoso Chevalier que es el mejor fabricante de instrumentos matemáticos me dijo que no tenia catálogos y te mando solo el del otro fabricante de mucha reputación. No he podido ocuparme de tu última demanda de periódicos científicos, que según parece están destinados a formar un gabinete de lectura en todo forma. Solo le encuentro un inconveniente y es que siendo tan voluminosas las remesas no se podrán mandar con los pasajeros (...) Me parece recordarte el mejor periódico de medicina que pides, porque van dos o tres de los mejores entre los libros dedicados a formar la biblioteca médica que imaginó Gutierrez, cuyos libros mandaré asi que estén empastados (Centón 195).

Al mismo tiempo, la traducción pone en evidencia la relación con los idiomas y por ende, supone una valoración sobre otras culturas.

En una carta fechada el 29 de mayo de 1838, enviada desde París, Pepe, su hermano, le refiere:

Dentro de tu carta viene una listita de libros que seguramente no leíste, pues tiene tanto disparate que apenas he podido entender los títulos. Vaya una muestra: "Epuxres de la machum a vapeur ¿feulles aseu legend Bachelier". He adivinado que Epuxres quiere decir études. Te mandaré todos esos libros en $1^{\circ}$ ocasión que no será muy pronto, pues el paquete de Burdeos y la Sílfida, que son los primeros que deben salir, acaban de llegar ahora casi a un tiempo (Centón 183).

Tal como el ejemplo anterior ilustra, hay otros numerosos pasajes que evidencian la presencia del francés, el inglés y el italiano como lenguas de intercambio. En todos los 
casos, se presentan los textos en su lengua original y la traducción realizada por Del Monte.

En la nutrida correspondencia que es objeto de traducción se destacan las cartas del italiano Primo Colina y las del inglés Richard Madden. Con este último fue célebre el intercambio epistolar respecto de la libertad de Juan Francisco Manzano.

Además, en las cartas entre paisanos cubanos ${ }^{65}$ también abundan frases en otras lenguas (sobre todo en francés) e intentos de escritura en distintos idiomas tal es el caso de una carta escrita por J. J. Milanés en italiano, en la cual se vehiculiza un soneto que pertenece a otro escritor, Pedro Oller: "Escusate mi la fantástica voglia di scrivere nella dolce favela del Tasso: senza piu, mandate sopra il cuore di costro amico e servo" (Centón 68).

El intercambio de libros, los préstamos y los encargos de libros y publicaciones al extranjero son referencias constantes en el epistolario delmontino:

P.D. En días pasados fui con José Antonio a su escritorio de U. cuya llave nos dios Mendez y saqué de allí la tragedia que llevó Marrero por encargo mío. Le falta el frontis y por lo mismo no sé quién es el traductor; pero supuesto que la tradujo Huertas, está buena, se puede jurar que esta no es su traducción -De Juan Muñoz y Castro, 1838 (Centón 286).

En otra carta, fechada el 20 de octubre de 1838, J.J. Milanés le dice a Del Monte:

Mi caro Delmonte:

Con el amigo D. Pedro Guiteras que parte para esa le remito la María, suplicándole que me dispense el haberla demorado tanto.

$\mathrm{Y}$ he de pedirle una merced. Que me remita V. con dho amigo las tres comedias de Tirso de Molina que ha publicado Duran, si es que las tiene V. en su poder, pues me es de alguna urgencia ver la María de Molina.

He visto una crítica de mi Espósito, si dignamente ha de intitularse crítica la que me pone reparos sin especificaciones. En ella se dice que hay en mi composición versos inarmónicos, trozos oscuros, faltas de rima y se da a

\footnotetext{
${ }^{65}$ La expresión "paisano" es usada en la correspondencia de Del Monte, tanto por él como por otros para referir a la persona que pertenece a la misma tierra, país. Por ejemplo, se advierte este uso en la carta que le dirige Domingo del Monte a Don Andrés de Arango (Diputado en Cortes- fechada el 20 de abril de 1836, que se inicia: "Mi querido paisano". Ver Tomo I, "Cartas políticas (primera época 1836-1838)" en Escritos de Domingo del Monte.
} 
entender que Vds. me celebran mas de la cuenta. No sé quién es el Conciso que la suscribe, pero yo quiero ser mas conciso que él, guardando la mas silenciosa indiferencia. - No he visto aun la Siempreviva, de modo que ignoro qué tal me para Suzarte. Confesemos que siempre me hace favor, como quiera que me zurre. Me salva de la ominosa oscuridad!

Recibí por su suegro La Tía Fingida, y le agradezco con alma y vida el sabroso rato que me dio la lectura de ese brillante desperdicio que se le cayó a la pluma creadora del Quijote.

Memorias al concilio neutri-clásico-romántico por no decir racional (Centón 254).

En esta breve carta se condensan varios de los elementos referidos con antelación. Por un lado, el tema de los préstamos y la circulación de los libros. En este caso, obras de Tirso de Molina, que — como ya se ha mencionado- funcionan como modelos de imitación. Por otro lado, la carta revela otro episodio de lectura crítica. En la carta, Milanés hace uso de la itálica para señalar la distinción de la palabra en cuanto a su acepción. Como el autor no está de acuerdo con los señalamientos que ha realizado un desconocido sobre su obra "Espósito" emplea la carta como vehículo de excusa y reclamo. Al mismo tiempo advierte que las críticas siempre son buenas porque de alguna manera salvan de la oscuridad a los escritores.

Por último, la carta se cierra con una salutación particular que revela la presencia de un grupo tertuliano de características singulares: el "concilio neutriclásico-romántico por no decir racional" sintetiza con ingenio las estéticas superpuestas que caracterizan a las producciones literarias cubanas del periodo.

Por otra parte, la tarea de traducción es considerada como un trabajo que permite a los escritores más nóveles tener algunos ingresos extras. Al mismo tiempo, el epistolario revela la preocupación por el pago de las ediciones, tanto de las revistas como la de los ejemplares de las obras. En este sentido, las letras comienzan a configurarse como un espacio mercantilizado. De ello son ejemplos los siguientes fragmentos.

En carta fechada el 28 de diciembre de 1838, Juan Muñoz y Castro expone: 
Ya está para salir a la luz el tomo segundo de mi traducción, que me costará, lo mismo que el primero, mas de 200 p. y el número de suscriptores no alcanza a cubrirlo (Centón 285).

Otra carta de A. de Arango, enviada a Del Monte desde Madrid en abril de 1837 expone:

Supongo que conocerá V. la obra titulada De la democracia en America por M.A Tocqueville, la cual ha sido traducida por dos jóvenes estudiantes a quienes yo protejo, y les he indicado que cuenten con V. para que cuide la venta de los ejemplares que remitan a esa Isla para venderse: asi procure V. buscar personas de confianza a quien consignar la venta, pues en ello hace V. un servicio mui marcado a dos jóvenes pobres y aplicados (Centón 85).

En síntesis, la lectura y el análisis de las cartas que constituyen el epistolario personal de Del Monte ofrecen un corpus discursivo en el cual se observan prácticas de lecturas privadas e íntimas, pero también públicas y colectivas. Las cartas se constituyen para estos letrados decimonónicos en textualidades sobre las que vuelcan críticas literarias e ideas políticas. Al mismo tiempo, es vehículo de obras y fragmentos de obras. En este sentido, la carta no responde a la clasificación de "género primario" que define Bajtín $(1982)^{66}$, sino que en relación a sus usos y alcances, se constituye como un género con fronteras más lábiles y entraría dentro de la clasificación de los géneros secundarios, que absorben en ellos a los simples o primarios.

A lo largo de estas páginas hemos realizado varias referencias sobre las ideas estéticas que Del Monte y su grupo privilegiaron y se han adelantado algunas observaciones en fragmentos de cartas.

\subsection{Impresiones de la identidad: imprentas, publicaciones y lecturas}

Si bien en la isla de Cuba se registran imprentas desde 1720, la censura y el restringido ambiente intelectual generaron producciones muy escasas. Con el regreso del dominio español tras la ocupación inglesa (1762-1763), los Capitanes Generales de la Ilustración animaron la actividad editorial en la ciudad de La Habana. Como permiten aseverar los estudios específicos sobre el tema, el asentamiento paulatino de la

${ }^{66}$ En Estética de la creación verbal (1982) Mijail Bajtín desarrolla en el capítulo "El problema de los géneros discursivos" su insoslayable definición sobre los géneros primarios y secundarios. 
María Pía Bruno

imprenta abarca todo el siglo dieciocho y la actividad editorial comienza a expandirse no sólo sobre géneros sino también sobre temas cuyo tratamiento no era permitido ${ }^{67}$.

A medida que crece culturalmente la colonia, la imprenta comienza a tener una utilidad mayor, prueba de ello es que entre 1791 y 1799 se imprimieron cien folletos, cifra que iguala a los impresos desde la introducción de la imprenta en la isla.

Puede decirse, entonces, que sobre fines del siglo dieciocho se produce la consolidación definitiva de las letras impresas en Cuba con la fundación, el 24 de octubre de 1790, del Papel Periódico de la Havana a cargo del Capitán General Luis de las Casas. Este fue el primer periódico del país, publicado dos veces a la semana

${ }^{67}$ El tercer impresor de La Habana fue Blas de Olivo quien ya estaba establecido en la ciudad cuando llega al gobierno el Capitán General Ambrosio Funes. El Capitán General arribó con instrucciones de favorecer el desarrollo cultural de la isla por lo que pensó en la necesidad de estimular la impresión de libros y periódicos, para ello se contactó con Blas de Olivo quien le presentó sus ideas sobre el tema. Funes envió al Consejo de Indias sus consideraciones: "No habiendo copia de imprenta en esta plaza, ni en toda la Isla, se carece muchas veces aún de los libros más precisos para la educación cristiana y enseñanza de primeras letras. Con este motivo y el de civilizar más a estos vasallos, he tenido el pensamiento de facilitar aquella importante impresión, añadiendo a ésta la de gacetas, mercurios y demás papeles y noticias interesantes" (Toribio Medina 1904: 45). El proyecto fue rechazado y la isla tuvo que esperar una mejor ocasión pana tener periódico e impulsar la edición de libros.

En 1762 se establece la imprenta del Computo Eclesiástico a cargo de José Arazosa, dedicada a la impresión de oraciones, misas, calendarios de rezos anuales y otros impresos religiosos. En este taller se publicó en 1763 el folleto Relación y diario de la prisión y destierro, en el cual el obispo Morell de Santa Cruz narra su destierro por las autoridades inglesas durante la ocupación.

En 1776 se funda la imprenta de Esteban Bolaños que se mantuvo hasta 1817. De su taller, distinguido por la calidad de las ediciones y sus viñetas, salieron numerosos títulos de diversos géneros, entre ellos el libro del habanero Martín Félix de Arrate, "Teatro histórico, jurídico y político-militar de la Isla de Cuba y principalmente de su capital La Havana" (1789).

En 1781 se crea la imprenta de la Capitanía General "(...) El establecimiento gozó del privilegio de editar la Gaceta que empezó a salir a luz en 1782, cuya publicación tuvo en un principio a su cargo D. Diego de la Barrera, a quien sucedió D. Francisco Seguí, que se había enlazado con la familia de Olivos."

La Guía de Forastero comenzó a circular en 1781 en la imprenta de la Capitanía General. En sus inicios tenía 30 páginas pero ya en 1814 contaba con 284 páginas y circulaba bajo el título de "Guía de Forasteros de la Siempre Fiel Isla de Cuba y su Calendario Manual para 1814". Era un libro muy útil que daba al viajero numerosos datos de la isla referidos a su economía, cultura, historia, geografía, etc. Tenía una impresión muy cuidada en un formato de bolsillo $(13 \times 7,5 \mathrm{~cm}$.)

En 1787 se publica en los talleres de la Capitanía General de la Isla el libro del naturalista portugués Antonio Parra, Descripción de diferentes piezas de Historia Natural, las más del ramo marítimo, representadas en setenta y cinco láminas, el primer libro científico editado en Cuba. Parra que había llegado a Cuba como soldado en 1763 describe importantes especies de la fauna cubana, principalmente peces y crustáceos, los cuales ilustra en detallados grabados que resaltan el valor del libro.

El breve - y por cierto no exhaustivo - racconto que presentamos en esta nota tiene por objetivo mostrar el trayecto de la imprenta en Cuba en el siglo dieciocho a los efectos de pensar la configuración del panorama editorial y la actividad de las imprentas en el siglo diecinueve.

Para detalle y aportes documentales referidos al tema, se sugiere consultar José Toribio Medina ([1904] 2001). 
(jueves y domingo) y cuya edición se continuó hasta 1804. Su primer director fue Diego de la Barrera y se imprimía en el taller de Francisco Seguí en un formato de medio pliego de papel español a cuatro páginas. A partir de 1793, la Sociedad Patriótica se hace cargo de la redacción del periódico. En sus páginas se trataron diversas temáticas referidas a la política, la literatura, las ciencias y sobre todo la economía, además de abordarse las noticias de la ciudad. El Papel periódico de la Havana fue primordial para la difusión de las ideas sobre desarrollo económico que se discutían en la época.

En medio de las publicaciones permitidas (aquellas que no perjudicaban la religión, la moral, la obediencia, el respeto hacia las autoridades) surgieron otro tipo, como es el caso del Papel periódico, que no se limitaban a informar a sus lectores sobre las disposiciones de gobierno sino que sometían a su reflexión proyectos, planes, hipótesis. Con este fin, aparecen en sus páginas artículos sobre mejoras del cultivo de la caña de azúcar, fertilización, tratamiento de esclavos, introducción de cultivos y cuantos temas podían interesar a los ricos hacendados criollos ${ }^{68}$. También fue preocupación de este vocero de la Ilustración habanera, la salubridad, el ornato público, la educación, las buenas costumbres y cuanta idea novedosa podía servir al mejoramiento de la sociedad, sin olvidar las colaboraciones literarias.

El periódico cambia de nombre en dos oportunidades: en 1805, se convierte en el Aviso, con Tomás Agustín Cervantes en la dirección, y en 1810 Diario de la Habana, dirigido por José Agustín Caballero y con Nicolás Calvo como redactor. Finalmente, en 1845 se lo nombra Gazeta de la Habana, pierde su carácter comercial y literario y se transforma en órgano oficial del gobierno colonial.

Hasta 1812 se crearon una veintena de periódicos de corta tirada y efímera vida; impulsados por las personalidades de vanguardia que recogen en sus páginas noticias sociales, llegadas y salidas de barcos, artículos económicos, de divulgación científica y colaboraciones literarias. Los redactores de estas publicaciones eran, por lo general,

\footnotetext{
${ }^{68}$ El Papel Periódico de la Havana, como la mayoría de las publicaciones, se mantenía por un sistema de suscripción. Para dar cuenta del éxito, en 1794 el periódico contaba con 120 suscriptores que pagaban seis reales al mes, fondos que servían para sostener la Biblioteca Pública de la Sociedad Patriótica de La Habana. La mayoría de estos suscriptores eran lectores que pertenecían a la clase hacendada más poderosa de la isla.
} 
defensores de la ética y de la ideología del grupo criollo y en ocasiones dejaban entrever opiniones políticas en forma velada, dada la férrea censura ejercida por la Iglesia.

Entre los periódicos más importantes se destacan: El Regañón de la Havana (1800-1801), dirigido por Buenaventura Pascual Ferrer; El Criticón de la Havana (1804); El Lince (1811), El Patriota Americano (1811-1812), y Gaceta Diaria y Mensajero Político, Económico y Literario (1811), entre otros.

Con la intervención napoleónica a España y el fuerte movimiento de resistencia popular encabezado por los liberales en la península se pone en vigencia la Constitución de Cádiz de 1812 y con ella la libertad de imprenta, ambas medidas abarcaron a los dominios coloniales españoles en América ${ }^{69}$. En Cuba se desató un auge notable de publicaciones, en especial muchos folletines y hojas sueltas, pero también se impulsó la creación de periódicos; sólo en 1812 circularon alrededor de veinte en La Habana ${ }^{70}$. Cuando se restaura la monarquía muchos de estos periódicos desaparecen al restablecerse el régimen de censura.

De los periódicos literarios que aparecen en la década del veinte ${ }^{71}$, dos sobresalen por la calidad de sus redactores y colaboradores, Biblioteca de Damas (1824-1826), dirigido por el poeta José María Heredia y La Moda o Recreo del

\footnotetext{
${ }^{69}$ La Constitución de 1812 oficialmente estuvo en vigor sólo dos años, desde su promulgación hasta su derogación en Valencia, el 4 de mayo de 1814, tras el regreso a España de Fernando VII. Posteriormente se volvió a aplicar durante el Trienio Liberal (1820-1823), así como durante un breve período en 18361837. La constitución establecía la soberanía en la Nación (ya no en el rey), la monarquía constitucional, la separación de poderes, la limitación de los poderes del rey, el sufragio universal masculino indirecto, la libertad de imprenta, la libertad de industria, el derecho de propiedad o la fundamental abolición de los señoríos, entre otras cuestiones. Además, incorporaba la ciudadanía española para todos los nacidos en territorios americanos, prácticamente fundando un solo país junto a las excolonias americanas.
}

${ }^{70}$ Los periódicos también surgen en el interior de la isla, tal es el caso del primer periódico de Puerto Príncipe (Camagüey), El Espejo de Puerto Príncipe (1813) editado por Mariano Seguí; el segundo de Santiago de Cuba, El Canastillo (1814), fundado por el poeta Manuel María Pérez y en 1819 el gobierno principeño pone en circulación la Gaceta de Puerto Príncipe (1819).

También se destaca entre las publicaciones de la época El Filarmónico Mensual de la Habana (1812) dirigido por Francisco de Frías, primera publicación especializada editada en Cuba y dedicada a la música.

71 Entre los más notables están El Observador Habanero (1820), de carácter científico y literario en el que colaboraron Félix Varela, Santo Suárez, José Agustín Govantes y Nicolás Escobedo; El Indicador Constitucional (1820); Diario Liberal y Constitucional de la Habana(1820); Lira de Apolo (1820), escrito en versos; El Argos (1820) donde se defienden las ideas separatistas, El Mosquito (1820), periódico satírico; El Mercurio Cívico (1821) y El Revisador Político y Literario (1823). 
Bello Sexo (1829-1831) a cargo de Domingo del Monte. Por lo general, la crítica señala que éstos, junto a El Nuevo Regañón de la Habana (1829) y el Puntero Literario (1830), abren el período de las publicaciones románticas en $\mathrm{Cuba}^{72}$.

En las ciudades del interior se produce un salto de calidad en las publicaciones periódicas al aparecer La Minerva (1821) en Santiago de Cuba, una de las mejores de la época por su contenido y forma elegante, dedicado a la divulgación científica, literaria y tratamiento de los temas políticos; en la ciudad de Trinidad se funda Corbeta Vigilancia (1820) por Cristóbal Murtha de corte muy similar a los periódicos de su época y en Matanzas aparece un periódico único, La Aurora de Matanzas (1828) que marca un cambio cualitativo, tanto en el modo de redacción, el renombre de sus colaboradores y la belleza de su diseño. Se publicó hasta el año 1857 en que se funde al periódico Yumurí y se publica como Aurora de Yumurí.

Terminado el segundo período constitucional en España (1820-1823), la censura en la colonia de Cuba dejó poco espacio para las ideas y solo se permitieron publicaciones que no tocaran los temas políticos y sociales, por lo que estos asuntos fueron tratados desde el extranjero. En esta década del veinte se redactan desde Nueva York, El Habanero (1824-1826) de Felix Varela; en México El Iris (1826) y Miscelánea (1830-31) de José María Heredia y El Mensajero Semanal, desde Nueva York, en Estados Unidos (1828-30) a cargo de Félix Varela y José Antonio Saco.

La década del treinta del siglo diecinueve marca un viraje cualitativo en el periodismo de la isla, por el énfasis cultural de sus páginas y la variedad de temas escritos por jóvenes colaboradores como José Jacinto Milanés, Gabriel de la Concepción Valdés, Anselmo Suárez y Romero, José Joaquín Palma, Cirilo Villaverde y otros muchos. Todos relacionados con Domingo del Monte, quien, como ya hemos

\footnotetext{
${ }^{72} \mathrm{Si}$ bien, en el desarrollo de esta investigación hemos tratado de dilucidar el lugar que Domingo del Monte ocupó en las letras cubanas decimonónicas y cuál ha sido su relación con las corrientes estéticas vigentes, la denominación general "románticos" que se atribuye a esta generación es compartida por muchos críticos. Entre los que se destacan Cintio Vitier y José Lezama Lima. Sobre el primero, se sugiere ver las lecciones Tercera, Cuarta y en especial, la Quinta lección de Lo cubano en la poesía. A su vez, Lezama Lima en la Antología de la poesía cubana, Siglo XIX distingue entre poetas románticos (grupo que integra Del Monte) y los poetas populares (Ramón Vélez Herrera, José Fornaris, Francisco Poveda, Juan Cristóbal Nápoles Fajardo "el Cucalambé".

También el crítico cubano Salvador Bueno (1999) considera que la generación de Del Monte es romántica-costumbrista.
} 
señalado, ocupa diversos cargos culturales que le permiten establecer redes de contacto con escritores que colaboran como corresponsales y periodistas en distintas publicaciones, dentro y fuera de la isla.

Como ya dijimos, en 1831 se crea la Revista y Repertorio Bimestre de la Isla de Cuba, dirigida por Mariano Cubí y Soler; a partir del segundo número cambia su nombre por Revista Bimestre Cubana, dirigida por José Antonio Saco, al hacerse vocera de la Comisión de Literatura de la Sociedad Patriótica. Esta revista se convierte en una de las publicaciones culturales más importantes del siglo diecinueve cubano. En ella colaboran los principales intelectuales de la isla y en sus páginas se abordan temas medulares de la sociedad dentro de los moldes permitidos por las autoridades. Fue la tribuna de los anhelos criollos hasta que el gobierno colonial desterró a José Antonio Saco en 1834 y sus redactores dejaron de publicarla en protesta por la arbitrariedad.

Aparece también en 1831 el periódico Lucero de la Habana, publicación en la que se introdujeron notables cambios al refundirse con el Noticioso Mercantil para dar lugar al Noticioso y Lucero de La Habana (1834). Para su impresión, sus dueños compraron una moderna prensa norteamericana que entregaba 1500 diarios por hora. Fue la primera empresa periodística de Cuba, con una mayor tirada, circulación diaria, cambio de formato, tamaño y diseño de títulos y viñetas. Se publicó hasta 1844 ofreciendo información sobre economía, política, historia y cultura.

La censura junto con el bajo nivel demográfico de la población alfabeta hacía que las revistas no tuvieran larga vida, dado el costo y los pocos suscriptores a pesar de la notable calidad de algunas de ellas.

En cuanto a la producción de libros y folletos literarios, por los mismos motivos que se enunciaron, su producción no era rentable. Por lo general, los autores costeaban las tiradas limitadísimas de sus textos, y la poesía aparecía como el género más publicado. Domingo del Monte insiste en muchos de sus textos en la carencia cultural de los cubanos y pone su atención en este aspecto cuando asume como secretario de la Sección de Educación de la Sociedad Económica.

Los temas de divulgación científica ocupan el interés del reducido círculo intelectual, y por esta razón, también se publican folletos, memorias, manuales y 
traducciones de autores extranjeros con temas de importancia para el progreso económico y científico.

El desarrollo de la imprenta y de un incipiente mercado editorial permite hipotetizar sobre las prácticas de lectura decimonónicas. Las listas de los textos publicados exponen los intereses en cuanto a géneros y temas preferidos por aquellos suscriptores que pagaban por las publicaciones. Al volumen de textos impresos de tipo jurídico-administrativo propios de la esfera edil se suman, entonces, otros: religiosos, políticos, económicos, culturales y hasta aquellos destinados especialmente a las mujeres $^{73}$.

En este sentido, y como ya mencionamos, Del Monte lanza la publicación de un periódico destinado a las mujeres, pues también consideraba que éstas debían tener una educación cuidada. La Moda o El recreo semanal del bello sexo fue un periódico adquirido, principalmente, por las hijas de los hacendados criollos.

En la novela Cecilia Valdés $(1839)^{74}$ de Cirilo Villaverde aparecen varios episodios en los cuales se narran escenas de lectura, en especial, la lectura recreativa realizada por los jóvenes de la casa. En las páginas de la novela, La Moda aparece reiteradamente como una publicación que forma parte de la vida cotidiana de los Gamboa. Cuando el narrador describe la casa "peculiarmente habanera" de esta familia señala:

Sobre los tales muebles se hallaban varios libros, unos abiertos, otros cerrados o con una o más hojas dobladas por la punta, empastados a la española, con canto rojo, todos al parecer de leyes, según podía notarse, leyendo los letreros dorados en los lomos de algunos. En el sofá únicamente dos periódicos en forma de folletos; el más voluminosos con un malísimo grabado que representaba los figurines de un hombre, una mujer y un niño, y llevaba por

\footnotetext{
${ }^{73}$ Se sugiere ver el artículo de José María Aguilera Manzano (2007), "Publicaciones periódicas e imprentas de La Habana entre 1824 y 1845 en los archivos cubanos y españoles" en el cual facilita el trabajo del investigador al ofrecer el catálogo completo de todas las publicaciones y de las imprentas de La Habana en el periodo consignado. El preciso y exhaustivo catálogo permite reconstruir el panorama editorial de la época, pero al mismo tiempo, examinar los títulos de las publicaciones posibilita al investigador considerar imaginarios sobre el universo de los lectores.

${ }^{74}$ La primera edición del tomo I de la novela de Cirilo Villaverde se publica en 1839 y consta solo de los ocho primeros capítulos. Sin embargo, la novela se publica en forma completa, con el tomo II, en 1879. En 1882, sale publicada una versión definitiva con el subtítulo "La Loma del Ángel”.
} 
título La moda o Recreo Semanal, el otro El Regañon (Primera Parte-capítulo VII: 64$)^{75}$

A continuación transcribimos un diálogo extenso entre los hermanos Leonardo, Carmen y Adela, en el cual se puede apreciar el lugar que ocupaba la revista en las actividades sociales de los habaneros.

-Vamos a la tienda de Madama Pitaux, que ahora vive en la calle de La Habana número 153. Hace poco que ha llegado de París y, según dicen, ha traído mil curiosidades. De camino pensábamos dar una vuelta por la Loma del Ángel. -Para ir a la Loma ya es muy tarde. Pasan de las once. Y ahora que me acuerdo, ¿han visto Vds. el número IV de La Moda o Recreo Semanal? Desde el sábado se repartió y está muy interesante.

-¿Tú le tienes ahí?- preguntó Carmen- Es extraño que no nos hayan enviado nuestro ejemplar, estando suscritas.

-¿En dónde se suscribieron ustedes?

-En la librería de La Coba, calle de la Muralla, que es el punto más cercano.

-Pues reclamen allá. El ejemplar que yo leí estaba en el mostrador de la botica de San Feliú, porque el mío me ha faltado también. No son nada exactos que digamos, los repartidores.

-¿Has averiguado quién es la Matilde de que habla La Moda?- pregunto Adela a su hermano-.Porque Carmen cree que es una que todos nosotros conocemos. -A mí se me figura — dijo Leonardo- que es un ente imaginario. Tal vez Madama Pitaux sepa algo.

-Pues a mí se me ha puesto - dijo Carmen- que la Matilde de La Moda no es otra que Micaelita Junco. Sucede que ella es la más elegante de La Habana.

-Voy creyendo que tienes razón- dijo Adela-. No puedo negar que el vestido y el peinado que llevaba anteayer en el Paseo Micaelita Junco son idénticos al figurín de La Moda del sábado antes pasado. Por cierto que no me gustó el peinado a la Jirafa. La trenza es demasiado ancha y los bucles muy altos; luego por detrás la cabeza luce desairada (Primera Parte- capítulo XI: 109).

Susana Zanetti, en su insoslayable obra La dorada garra de la lectura. Lectores y lectoras de la novela en América Latina, nos ha enseñado a leer las escenas de lectura

\footnotetext{
${ }^{75}$ Todas las citas de Cecilia Valdés que ilustran este capítulo corresponden a la edición de Letras Cubanas (2002).
} 
a partir de pensar de qué manera "el Autor sale a escena dando al simulacro un haz de significaciones". Con lucidez advierte que "la novela ficcionaliza una constelación de lectores y de situaciones de lectura que tienden puentes peculiares entre literatura y vida. De allí también que difícilmente renuncie a intervenir, sobre todo durante el siglo XIX en las discusiones acerca de los modelos de familia, genéricos y sociales convenientes para naciones que cumplen o buscan una rápida modernización” (2002: 14). En este sentido, la novela de Cirilo Villaverde concebida como un cuadro de costumbres busca retratar hábitos sociales, por eso ofrece en sus páginas múltiples escenas de lectura, diálogos entre los personajes y reflexiones a cargo del narrador respecto de las formas en que estas publicaciones permeaban la vida social de los habaneros y cómo impactaba en sus lectores aquello que por sus páginas discurría. La intención de Villaverde de exponer con fidelidad el mundo habanero lo lleva a transcribir "casi al pie de la letra" una de las crónicas publicadas en La Moda y convertirla en uno de los capítulos de la novela. De este modo, el capítulo III de la Segunda Parte es una crónica publicada en La Moda sobre un baile en la Sociedad Filarmónica. El mismo autor se ocupa de hacer la referencia necesaria en una nota al pie $^{76}$. Hay un efecto de realidad que genera la transcripción de la nota: los dos géneros, el de la publicación y el de la novela se cruzan y tal como ilustra el ejemplo citado, los personajes no saben si lo que revela el semanario es imaginación o bien es verdad. Al mismo tiempo, la incorporación de una crónica en la novela genera también un efecto de verosimilitud que el autor busca reforzar para construir este cuadro costumbrista.

En la misma crónica, en la cual se hace referencias a las conquistas y cortejos que se realizaron en la velada descripta, se lee como dato llamativo "De paso debemos decir, sin embargo, que el norte de las galanterías de André por aquella época se dirigía a otra beldad muy distinta de Isabel Ilincheta, la misma que perdió por tímido, y que ganó por osado el literato dominicano Domingo del Monte, si no estamos muy equivocados, en la noche de que estamos hablando" (152).

La escenificación de la opinión es una de las estrategias advertidas en las publicaciones periódicas de la época. Este recurso de la escenificación, que tiene como

\footnotetext{
${ }^{76}$ Villaverde, Cecilia 145.
} 
fin influir en la opinión de los lectores, se da mediante un doble juego. Por un lado, los editores crean personajes ficcionales que en escenas ficcionales exponen su opinión (en cuentos, relatos satíricos breves, diálogos), por otro, se ficcionalizan opiniones de los lectores. Esto evidencia una transformación de las publicaciones, pues aquello que se publica adquiere paulatinamente un tipo de autoridad particular que compite con otros sistemas legitimadores ya establecidos.

Al respecto, Susana Montero (2001) en el análisis que realiza sobre el semanario La Moda o Recreo Semanal, advierte que ésta no fue la primera publicación destinada a las mujeres en Cuba, por el contrario, ofrece una lista que contrapone esa idea. No obstante, sí señala que La Moda trajo consigo un tratamiento de los asuntos femeninos totalmente novedoso. Las publicaciones anteriores habían sido concebidas fundamentalmente como instrumento para la educación moral de la mujer en los cánones patriarcales de subordinación al hombre, de abnegación, pudor y modestia como máximas virtudes femeninas; del respeto a sus "sagrados" deberes en tanto esposa, madre y guardiana de la paz del hogar, y a la inviolabilidad "natural" de los límites entre las esferas pública y privada. En tal sentido, Montero revela que:

se observa el predominio en sus páginas de las historias de mujeres ejemplares por su fidelidad conyugal y austeridad, así como los sermones éticos contra la vanidad, la desatención al hogar y la coquetería femeninas; sermones que, por otra parte, habían constituido desde los inicios del Papel periódico la vía principal de acceso a la temática de la mujer en el periodismo regional. Los restantes materiales de estas primeras revistas literarias femeninas, en línea general elementales (noticias sobre modas, referencias al contexto social, anécdotas, curiosidades, poemas), quedaban subordinados de una u otra manera a ese propósito didáctico-moral que constituyó su carácter distintivo (2001: 1).

En cambio, La Moda renovó los criterios al considerar a la mujer como consumidora y objeto de consumo. El tratamiento ligero de los temas, la irreverencia y la ponderación de la coquetería femenina para incentivar la compra de la revista son algunas de las marcas que distinguen a esta publicación. La reflexión de Montero que a continuación exponemos sobre el valor de esta publicación deja entrever ese rasgo de “escenificación de la opinión” que anteriormente esbozamos: 
Buen ejemplo de ello es el cuidadoso tratamiento que se le daba a la sección de modas -la primera en el orden de la revista--, y una de las más originales, sobre todo en los primeros meses de la publicación, cuando conformó una suerte de episodio semanal acerca de una familia del elegante mundo habanero, ofrecida en tanto paradigma o criterio de autoridad. A través de aquélla los editores no sólo dictaban los parámetros que debían regir el atuendo de los lectores, sino que sus personajes les servían de portadores de los conceptos que iban conformando la imagen androcéntrica de la mujer objeto, cuyo supremo valor de cambio radicaba en su capacidad de agradar al hombre por su belleza física (2).

En el ámbito letrado decimonónico la mujer fue también objeto de escritura. Estas publicaciones escritas por hombres y destinadas a lectoras tenían como finalidad la instrucción moral, y al mismo tiempo, la construcción de una imagen de mujer que se correspondiera con ciertos ideales liberales. La dupla "capitalina y hermosa" condensa el ideal femenino al que se aspiraba desde las páginas del semanario. Como sintetiza Montero:

Ofrecer páginas "lo último" de la literatura, venía a ser para sus en sus promotores algo semejante, en otro plano a ofrecer "lo último" en los atuendos de París, o que dar aviso a las lectoras sobre la mercadería recién llegada a la tienda de Madama Pitaux o a la botica de la calle Mercaderes. Todo ello permitía infundir en estas destinatarias el deseo de la modernidad, la ilusión de cambio a nivel individual, de acceso al triunfo, al tiempo que entre líneas se les inculcaba el rechazo de la singularización y la necesidad de conservar el orden social (8).

Valga como ejemplo de estas palabras, la opinión del redactor de La Moda (26 de septiembre 1829):

Tendiendo el hombre por una ley natural [...] a no andar al revés de sus coterráneos se sujeta espontáneamente a los usos de estilo, y se empeña en mejorar su trage y seguir la moda; porque el equipage y la ropa distinguen ciertamente la persona e infunden favorable opinión de ella, arrancan los derechos de trato y consideración [...] de suerte que debe considerarse como natural el deseo de obedecer las leyes de aquella fingida divinidad [...]. Por eso el hombre juicioso es el primero en seguir los usos sociales y los caprichos 
inocentes de la moda, sin singularizarse [...]. En suma, los modos de vestirse tienen fuerza de leyes que todos siguen y que ninguno se atreve a dispensarse, tomándose por locura el intento de contrariarlos [...] son además utilísimos y de gran influjo moral esos cambios de moda, pudiendo decirse que son también medios que emplea la naturaleza para mejorar la especie racional y engrandecer los pueblos (Montero 2001:8).

Víctor Goldgel en Cuando lo nuevo conquistó América (2013) aborda, en un análisis minucioso de textos y publicaciones, esta fascinación por la novedad, rasgo que caracteriza a los grupos sociales hispanoamericanos de la primera mitad del siglo diecinueve.

Goldgel señala que hay que diferenciar entre dos aspectos de la moda, uno sincrónico y otro diacrónico. El segundo, aquel que tiene que ver con el sentido por el cual cada moda deja paso a la siguiente es el que interesa, pues revela un dispositivo social de renovación periódica de un amplio espectro de objetos y prácticas: ropa, muebles, carruajes, formas de caminar y de conversar, usos del tiempo libre, bailes, literatura, etc. (111).

Para este autor, a principios del siglo diecinueve se quiebra la "estabilidad de la vestimenta" y esto ocurre primero en Cuba por el boom azucarero y la prosperidad económica que éste genera. La moda es solo uno de los aspectos que expone una virtual revolución en los patrones de consumo originada cuando la cultura hispanoamericana decimonónica comienza a absorber cantidades inusitadas de productos extranjeros.

La caída del monopolio español se halla entre los principales factores que posibilitaron el acceso a lo nuevo. El libre comercio generó que las elites hispanoamericanas tuviesen un afán acumulativo de estos objetos novedosos dignos de los coleccionistas de siglos anteriores. Goldgel destaca que "consumo y maravilla parecen ir de la mano" (115). Tanto descubrimientos e inventos como objetos más prosaicos son descriptos en las publicaciones con la retórica de lo maravilloso.

Como sostiene Goldgel, si la prosperidad económica y la caída del monopolio hicieron posible un mayor consumo y el fortalecimiento de la moda, el discurso de la civilización los volvió legítimos. Consumo y moda se convierten, entonces, en formas de alcanzar una vida civilizada y, tal como advierte el fragmento correspondiente a $L a$ 
Moda o Recreo Semanal citado más arriba, la moda propicia el mejoramiento de la sociedad.

El trabajo de Víctor Goldgel que traza relaciones entre Cuba, Chile y Argentina nos permite pensar en la confección de un tramado simbólico de signo ilustrado hispanoamericano. Aunque las primeras manifestaciones de una preocupación por la innovación y la moda se originaron en Cuba, el muestreo realizado evidencia que también se desarrollaron prácticas culturales muy similares en el ámbito del Río de La Plata y en Chile. En palabras del autor:

Durante las décadas de 1830 y 1840, tanto en el sur del continente como en Cuba, los hispanoamericanos consideraron que a través de la moda era posible intervenir en la dinámica de esa totalidad social. En un sentido, esto era una novedad, y por lo tanto requería defensas y explicaciones. Pero, en otro sentido, era algo obvio. La contradicción se remonta al origen mismo de la moda que desde un comienzo había sido definida como un nuevo uso o costumbre, en especial en la vestimenta. Si en tanto costumbre la moda constituía un objeto de reflexión legítimo, en tanto nueva ponía en duda esa misma legitimidad; una costumbre nueva, de hecho es algo tan paradójico como una novedad de siempre. Sin embargo, esta paradoja empieza a quedar superada debido al ascenso de lo nuevo como fuente de asignación de valor (138).

La moda no hace referencia solo a la vestimenta y a los objetos de lujo. También se aplica a la literatura. En este sentido, como hemos observado en el desarrollo de estas páginas, en diversas textualidades Del Monte alienta el consumo de la "novedad literaria" en el grupo de escritores con los cuales interactúa. Novedad y extranjería se resumen en una de las prácticas letradas más desarrollada por Del Monte: la traducción. Por otra parte, su trabajo como director de La Moda lo ubica en un lugar privilegiado para configurar escenarios de consumo que propicien una vida civilizada. Es por ello que el ansia por ser modernos revela una concepción de la moda que la define con un fin utilitario más transcendental, es el vehículo de civilización. La moda cambia a una velocidad inusitada en la primera mitad del siglo diecinueve, y expone en esa vertiginosidad cambios profundos tanto en lo político-social como en lo cultural. 
Para explicar el alcance de este proceso transformador, que abarcó entes más abstractos que la moda en relación a la vestimenta, predominaron en las décadas del treinta y cuarenta, construcciones metafóricas que gravitaban alrededor de la moda en tanto concepto que permitía identificar lo nuevo. La moda sindicaba ante todo, progreso y orden. Y personalidades como Domingo del Monte pregonaban estos beneficios en verdaderas gestas discursivas.

\subsubsection{La Revista Bimestre: epicentro de la Ilustración cubana}

Como ya señalamos en el derrotero de estas páginas, Del Monte es uno de los que ha fraguado el proyecto de introducir en la Sociedad Económica un grupo permanente de literatura. En 1831 toma forma un nuevo proyecto vinculado al grupo que se reúne en la Sección de Educación de la Sociedad Económica Amigos del País. Se trata de una revista literaria de amplio alcance y que, por la calidad a la que aspira, se decide colocarla en manos de la figura más reconocida dentro del grupo. El proyecto lleva el nombre de Revista Bimestre Cubana y para su dirección es designado José Antonio Saco. Esta revista, pese al breve tiempo en que se publicó, devino una de las más completas e importantes de todo el siglo diecinueve cubano ${ }^{77}$. Los más notables escritores del país publicaron artículos de fondo en la revista. Félix Varela, José de la Luz y Caballero, José Antonio Saco, Felipe Poey y el propio del Monte contribuyeron con sus colaboraciones a la calidad literaria de la Revista Bimestre Cubana.

Saco le dio a esa publicación un contenido enciclopédico que expresaba el espíritu de la Ilustración cubana y el rigor científico que lo acompañaba. La presencia de un pensamiento crítico de la realidad le imprimió a la revista las características de las más renombradas de Inglaterra y Estados Unidos. Dentro de esta concepción, el espacio de mayor agudeza estaba reservado a los ensayos sociales, culturales y científicos más que a los puramente literarios. Como señala Adioc Torres (2002) por esta razón, la publicación comenzó a ser mal vista tanto por el director de la Sociedad Económica, y enemigo personal de Saco, Juan Bernardo O'Gavan, como por el

\footnotetext{
${ }^{77}$ Para esta investigación contamos con la versión digitalizada de la revista en este primer periodo de publicación: $\mathrm{N}^{\circ}$ 1, tomo I, mayo-junio, 1831; $\mathrm{N}^{\circ} 2$, tomo I, agosto, 1831; $\mathrm{N}^{\circ} 3$, tomo I, septiembreoctubre, 1831; $\mathrm{N}^{\circ}$ 5, tomo II, enero-febrero, 1832; $\mathrm{N}^{\circ} 6$, tomo II, abril, 1832; $\mathrm{N}^{\circ}$ 7, tomo III, junio, 1832.
} 
poderoso intendente de Hacienda, Claudio Martínez de Pinillos, ambos destacadas figuras de la burguesía esclavista cubana. Pese a las sugerencias del grupo, en sus artículos Saco atacó directamente la trata de esclavos y, si bien era un lugar común entre los “jóvenes ilustrados" la visión crítica de la esclavitud, particularmente en lo que concernía a la estabilidad demográfica que permitía el predominio de los criollos blancos, en lo que no estaban de acuerdo entre ellos era en las soluciones posibles del problema; más aún, se discrepaba en la forma de enfocar el asunto.

Si bien consideramos que la Revista Bimestre conforma por sí misma un corpus de estudio vasto y complejo, no es objeto de esta investigación abordarla como tal sino poner en relación algunos de sus artículos que, entendemos, permiten reconstruir el panorama cultural de la época. Como en la edición y redacción de la Revista Bimestre Del Monte tuvo un lugar definitorio, conocer la propuesta literaria elevada desde las páginas de esta publicación es una manera de acceder al pensamiento delmontino dentro de cuyos límites se promovió la escritura del romancero letrado.

En el número 1 de la publicación, correspondiente a los meses de mayo y junio de 1831, en las palabras liminares dedicadas "Al Público" el editor organiza el contenido bajo tres aspectos: fundamentación de la revista, objetivo y temas a tratar.

En cuanto al primero, la revista se crea por carencia de publicaciones de esta índole y a imagen y semejanza de otras publicaciones con las que cuentan naciones más avanzadas como "Francia, Inglaterra, Alemania y Estados Unidos". En los primeros párrafos de la dedicatoria al público se advierte la misma justificación que opera en otras textualidades ya analizadas: la carencia como impulso creador. Pero, al mismo tiempo como condición que se establece en una relación de comparación, en este caso, en función de la civilidad que ostentan otras naciones. Y la forma de remediar esa carencia es la imitación de determinados hábitos. Sin embargo, para que la transpolación resulte exitosa y atienda a las demandas locales, se deben tener en cuenta las peculiaridades cubanas.

Digno es de asombro que en este suelo venturoso, suelo en que han encontrado su grata mansión la cultura y la elegancia no haya aparecido un periódico destinado a difundir y a generalizar el conocimiento de las obras propias y estrañas, de mayor mérito, a juzgarlas y calificarlas. Estas publicaciones que 
tanto empuje han dado a las naciones estrangeras son con muy pocas escepciones desconocidas entre nosotros $(3)^{78}$.

Como indica el editor, si bien las publicaciones han originado e inspirado en los pueblos la afición por la lectura que tan particularmente han marcado su carácter, aunque en la mayoría de los casos se trata de publicaciones trimestrales, en Cuba, como no hay otras revistas o folletines que traten estos asuntos, la revista que se presenta tiene un carácter bimestral.

La novedad es otra de las marcas que impregna la escritura del periodo. Ya vimos cómo se elabora esta idea en diferentes textos. En esta presentación es muy clara la relación entre novedad y tiempo. La novedad es algo que pasa rápido, es vertiginosa y cambiante. Por tal razón, la revista se presenta en este apartado como una solución que le permite a la sociedad instruirse sobre muchos y variados temas de la actualidad en forma amena y breve. La revista sirve, entonces, para estar al día y contribuye a saciar el hambre de lo nuevo que distingue a los grupos sociales a quienes está destinada. Dice el editor:

En nuestro siglo de conocimientos generales, deseamos todos estar al corriente de lo que pasa, o por mejor decir, vivir efectivamente en él. Investigar con circunspección y detenido examen las materias y adelantos sobre que todos los días se escribe, no es dado al hombre; ignorarlos todos, repugna al ánimo en quien obra el menor asomo de amor propio. A fin de obviar estos extremos, se pusieron en planta las Revistas, en las que además de los juicios que se hacen de las obras que aparecen, vemos ideas nuevas, breves, claras y sucintas de las materias mismas sobre que giran. Piensan sus autores para nosotros: coligen y abrevian para nuestro ahorro de tiempo: nos presentan el asunto bajo el aspecto más interesante: dirijen nuestra atención al punto principal de la cuestión y en pocas horas nos ponen en estado de hablar con magisterio de una obra ó de alguna materia (3-4).

El valor de las revistas es "incalculable" pues permiten que "los arcanos del conocimiento científico y literario sean manifiestos, patentes y comunes" (4) y no

${ }^{78}$ Todas las citas corresponden a Revista y Repertorio Bimestre de la Isla de Cuba. Número 1. Mayo y Junio 1831. Tomo I. Cuando la cita corresponda a otro número de la misma revista se indicará en cuerpo o en nota al pie. 
pertenezcan solo a un reducto humano. En consecuencia, al binomio novedad y ahorro de tiempo, se le suma otra característica de las revistas: socializan saberes que de otra manera quedaban siempre en manos de unos pocos. Gracias a las revistas "llegan a ser moda los conocimientos y ocupa en efecto uno de los primeros puestos la sabiduría en las prendas humanas" (4).

En cuanto al objetivo, el editor expresa que desean presentar "una obra instructiva, útil y amena", presentar los temas con claridad para la "pronta y fácil inteligencia de la generalidad de los lectores" (6).

En lo temático, el acento está puesto en la originalidad tanto de las obras como los juicios que sobre ellas se realizan. El editor, también destaca que se traducirán piezas publicadas en revistas extranjeras y se insertarán otras en verso y prosa escritas específicamente para esta publicación.

En estas palabras de presentación, el editor también refiere que la revista cuenta con corresponsales y colaboradores que son "las mejores plumas" dentro y fuera de la isla. Al respecto, el editor convoca desde esta presentación a los escritores que quieran colaborar con el "fruto de su trabajo" y enviar a la revista cuentos, descripciones, críticas de obras, adelantos en conocimientos científicos, etc.

En este sentido, las publicaciones ponen en evidencia las redes entre letrados y los contactos que urden el singular entramado del ámbito literario cubano.

El primer artículo de la Revista pertenece a Domingo del Monte y se titula "Primeras poesías líricas de España". Este artículo es particularmente revelador pues su tema se relaciona directamente con el romance como forma genérica.

Antes de que comience el artículo se listan fuentes de estudio consultadas, es decir, una especie de bibliografía. En este apartado se observan dos elementos que exponen algunas ideas ya desarrolladas. El primero de ellos es la contemporaneidad de esta bibliografía. Los estudios datan de 1815 a 1822. Y segundo, las tres fuentes son extranjeras, razón por la cual opera la traducción como práctica letrada.

En el primer párrafo, Del Monte divide el periodo de la poesía lírica en España en dos etapas, una desde el "nacimiento del verso hasta el reinado de Carlos I" y la siguiente, que se extiende desde esa fecha hasta la actualidad. Estos dos grandes momentos se diferencian en los poetas, la inspiración, el fin y el medio. 
La valoración positiva recae sin dudas en el primer periodo, al que Del Monte caracteriza como una nación entera de poetas que se inspiran en lo nacional:

No la caracteriza la supremacía de algún individuo sino la imaginación de todo un pueblo que se convierte en romances y canciones, cuando no conoce ni necesita modelos estraños, sino que infunde en todas sus producciones un verdadero espíritu nacional (10).

Los títulos que anteceden este artículo son obras que abordan el primer periodo y ofrecen una sinopsis a modo de reseña para identificar esa bibliografía:

La colección del señor Grimm contiene en general romances, cuya materia pertenece a la fabulosa historia de Carlomagno y sus doce pares. La obra del señor Depping es una colección variada de romances narrativos, y la Floresta del señor Faber contiene una colección variada de romances y de composiciones líricas que bajo el título Canciones, Villancicos y Cancionetas llenan casi todos los cancioneros y romanceros de España (10).

A continuación, explicita el objetivo que es "dar a los lectores alguna idea de esta gran masa de poesía popular". Siempre bajo la propuesta de abordar la materia desde la óptica más interesante y amena según el criterio de la revista, el autor aclara que más que detallar, se tratará de un bosquejo del asunto, en consecuencia, evitará las citas largas y las críticas particulares. Porque, como expresa, la literatura castellana tiene un valor en el espíritu nacional que le da armonía.

En el bosquejo que realiza, Del Monte parte de comparar la literatura con la evolución de los hombres y sostiene que hay poesía en estado de niñez, que por lo general es la narrativa, la que precede a la poesía de contemplación.

Para explicar la poesía española, primero ofrece una caracterización de la poesía arábiga. Luego sintetiza el efecto que se produce cuando se unen ambas culturas:

Obro Arabia en España el influjo que tiene sobre la ignorancia el conocimiento, pero en recompensa sintió ella la soberanía que una índole noble y elevada posee sobre ánimos más leves aunque de mayor cultura. Así es que mientras la literatura española se iba puliendo por el efecto que obró en ella la literatura arábiga, la influencia del espíritu caballeresco y acrisolado patriotismo de España sobre los árabes se hacía visible en el tono elevado que tomaron, en la impresión mas viva que les hacía la dignidad nacional (14). 
En este sentido, la valoración de la poesía española recae en la expresión del patriotismo. Toda la etapa del romancero español expone el espíritu del pueblo y como consecuencia, al considerar que Cuba está en una etapa anterior en el desarrollo de la civilización y de la cultura literaria, Del Monte estima que el romance es el género poético narrativo que mejor se presta para expresar el amor a la patria.

Algunos de los postulados respecto de la poesía que se presentan en este artículo serán retomados en el capítulo III cuando analicemos con mayor detenimiento las razones de elección del romance como género para vehiculizar el sentimiento patrio.

A continuación nos interesa reparar en otras características de la Revista Bimestre en relación a la propuesta editorial que oferta desde sus páginas.

El repaso de los índices de los siete números publicados entre 1831 y 1832 revela el abanico de temas que la revista abordó ${ }^{79}$. En general, los artículos tienen la estructura genérica de una reseña, es decir, son comentarios sobre otros artículos o libros que se publican en otras revistas. En la mayoría de los artículos se advierten tres partes distintivas: una descriptiva y una explicativa, las cuales se corresponden con el carácter pedagógico y formador que define la editorial y otra argumentativacomentativa en la que se vuelca la opinión del autor.

La novedad se instala como preocupación en la revista y esto denota el apartado "Novedades científicas y literarias" que está presente en todos los números en un lugar fijo, luego de todos los artículos y antes de la "Lista de obras publicadas en la isla, en Europa y EE.UU". Por último, la revista cierra con el apartado "Listado de suscriptores".

En el apartado "Novedades" se exponen noticias como descubrimientos científicos y lanzamientos culturales tales como inauguraciones, aperturas de colegios y premios que distinguen a personalidades de la cultura.

\footnotetext{
${ }^{79}$ A efectos ilustrativos transcribimos el índice del número 1 de la revista, en el cual se señalan los siguientes artículos: "Poesía lírica española", "Historia de la isla de Cuba", "Gramáticas latinas", "Educación del bello sexo", "Hidrofobia", "Agrimensura", "Geografía universal", "Graciosa apología sobre el uso del tabaco", "Obstetricia y museo anatómico". A continuación los apartados "Listado de libros impresos (distinción por librerías e imprentas).
} 
En todos los números hay un artículo sobre literatura y/o sobre enseñanza. Y como destacábamos en el inicio, los artículos de índole socio-económica ponen de manifiesto las preocupaciones del grupo ilustrado que integra la comisión de la revista. Por ejemplo, en el Número 6, correspondiente al mes de abril de 1832, se publica el ensayo de Saco "Memoria sobre la vagancia en la isla de Cuba". Y es tal la trascendencia, que en el Número 7 (junio de 1832), en el apartado de "Novedades" se vuelve sobre las notas principales del artículo. En éste, Saco analiza pormenorizadamente características, habitus, del hombre en Cuba, su relación con la naturaleza y con la economía. Con este ensayo, Saco se integra en la tradición de letrados que en Hispanoamérica comienzan a manifestar sus preocupaciones con respecto al hombre y los condicionamientos naturales y raciales que afectan su comportamiento $^{80}$. Como señala Dávila, hay en estos letrados una voluntad racionalizadora y una búsqueda de institucionalizar discursos cuyos principales enunciados postulaban la carencia de racionalización americana (Dávila 2005: 3).

En este sentido, la Revista Bimestre corrobora la hipótesis con respecto a que Cuba experimenta en este periodo un "sentido de identidad colonial" que se plasma en un discurso articulado por la modernidad. Esta identidad colonial en América se traza a partir de una nueva conciencia histórica que se expresa en el plano político-cultural y que es reconocible en los textos producidos en la época, pues en éstos se busca resolver de alguna manera el dilema de la entidad cultural americana frente a la cultura europea. El Americanismo que se advierte en los discursos epocales se entronca con un anhelo de modernidad que, en palabras de Dávila, puede ser pensada de, al menos, dos maneras. Por un lado, como un apego creciente a la naturaleza y a la realidad social de

${ }^{80}$ Andrés Bello y Domingo F. Sarmiento son referencias ineludibles cuando pensamos en letrados hispanoamericanos del siglo diecinueve. Sus obras ponen de manifiesto el afán europeizante y la voluntad racionalizadora que se expresa en múltiples proyectos que tienen por fin "ordenar el enorme yacimiento que significa américa". Recordemos también que el título completo de la Revista Bimestre Cubana fue Revista y Repertorio Bimestre de la Isla de Cuba. Tanto el título de esta publicación como los artículos allí publicados evidencian la intención descriptiva y clasificatoria. Los letrados consideran necesario realizar un inventario americano que clasifique y nominalice el espacio y a los sujetos. En consecuencia, abunda en el periodo una escritura descriptiva y de corte científico-naturalista. De esta forma, los escritores logran expresar y fundamentar una naciente conciencia americana. La temática de la naturaleza y su taxonomía sirven, además a un fin moral y cívico, pues, como sostiene Dávila (2005), a partir de ella se pretende civilizar. Para ampliar ver Ramos (1989); Rojas (2008). Y para acceder a un panorama del universo letrado en el siglo diecinueve hispanoamericano consideramos fundamental Jorge Myers (ed.) (2008), Historia de los intelectuales en América Latina. La ciudad Letrada, de la conquista al modernismo. 
ese Nuevo Mundo, por parte del hombre americano, cada quien fundamentando su propia localidad y sentido nacional; por otro, como el inicio de un amplio sentimiento continental de pertenencia e identificación, de defensa de este hombre americano y al mismo tiempo de independencia y diferenciación de la metrópoli (10).

Los artículos y las opiniones vertidas en las publicaciones de la Revista exponen esta incipiente conciencia criolla, que busca la diferenciación cultural y en el mismo gesto, la conformación de una identidad cultural americana pero que registre lo peculiar, la diversidad, lo local. Es por ello que abundan en la Revista Bimestre trabajos sobre la isla de Cuba, su geografía, sus habitantes, sus costumbres, su cultura. Y al mismo tiempo, se evocan estudios similares sobre otras regiones. El efecto no es solo comparativo sino de búsqueda de modelos foráneos de organización social.

Vale citar como ejemplo el artículo II "Noticias sobre Brazil en 1828 y 1829 por el presbítero R. Walsh" en el Número 7. El artículo muy extenso recorre casi todas las noticias de Brasil relacionadas a la población y a su historia, costumbres y naturaleza. El autor de la reseña (cuyo nombre se desconoce) despliega como estrategia retórica la comparación entre cada uno de esos aspectos con su par cubano. Por lo general, el resultado de esa comparación presenta a Cuba en sus faltas y carencias.

En Rio de Janeiro existen instituciones literarias que ya nos daríamos el parabién de tener en nuestra Habana, donde tanto se necesitan y donde por desgracia se han mirado con bastante indiferencia. ¡Ojalá que la enumeración de las instituciones literarias del Brasil pueda encender el espíritu público de los buenos cubanos y proporcionar a la patria las ventajas de la Ilustración! (196).

Si bien el autor descarga su juicio sobre varios asuntos novedosos pues son presentados como noticias, hay uno particularmente interesante y es el que refiere el proceso de esclavitud y abolición llevado a cabo en Brasil. Las valoraciones que el autor expone cuando aborda este tema permiten pensar de qué modo se instala públicamente en Cuba el debate respecto de la esclavitud y cómo se elaboran propuestas alternativas al sistema esclavista. En esta parte del artículo, los cuadros estadísticos que ilustran la página generan un ordenamiento de la información que opera en dos niveles. Por un lado y desde lo explícito, cada cuadro visibiliza cifras y por otro, y desde lo implícito dice más que todo un párrafo descriptivo. Es decir, los cuadros refuerzan con 
contundencia aquello que se expone mediante la palabra. Y también exponen un orden racionalizador sobre una materia dispersa. Por ejemplo, en la página 211 se aprecian cuadros comparativos entre los números de esclavos ingresados a Brasil antes de que se declarara la abolición de la trata. Además el autor agrega cuadros en los que suma los índices de esclavitud en Cuba (páginas 216, 217, 218 y 219) y los compara con cuadros que exponen el fenómeno en las colonias inglesas (páginas 220, 221, 222).

Dice el autor respecto de estos cuadros:

Todavía nuestra situación será más comprometida si volvemos los ojos al horizonte que nos rodea. Con ellos vemos ya el humo y el fuego que se levantan de los volcanes que han reventado y el horrendo combustible que devora las entrañas de las Antillas, amenaza una catástrofe general en el Archipiélago americano. Leed, compatriotas, leer la historia del porvenir en los padrones que sometemos a vuestro examen y después de haberos meditado con la detención que merecen decidnos si no oís los profundos quejidos de la patria agonizante (220).

La estrategia de la comparación está acompañada del comentario que explicita la postura del autor. Cuando compara el caso cubano con el sistema esclavista desarrollado en EE.UU, el autor no escatima valoraciones positivas y expresa el deseo de imitación para no caer en la barbarie ni tampoco correr el riesgo de una rebelión como la acontecida en Haití (1791-1804).

El horrendo tráfico de carne humana prosigue a despecho de las leyes y hombres que quieren usurpar el título de patriotas cuando no son más que parricidas, inundan nuestro territorio de víctimas encadenadas; y como si tanto no bastara, una apatía criminal deja vivir en nuestro seno a los africanos que redimidos del cautiverio por la política inglesa, arriban a nuestra costa. ¡Qué conducta tan contraria no siguen nuestros vecinos los Norte-Americanos! A pesar del prodigioso vuelo que ha tomado su país, a pesar que su población ha sido siempre cuatro quintas partes mayor que la de color, a pesar que la importación de esclavos está prohibida de un estremo a otro de la república y que es muy numerosa la inmigración de europeos, a pesar de que no tienen pueblos limítrofes que puedan infundirle temor, organizan sociedades, reúnen fondos, compran terrenos en la costa de África, establecen allí colonias, fomentan la emigración de gente de color, y redoblando siempre sus esfuerzos, 
si no han conseguido lo que desean, han hecho todo lo que pueden para merecer el título de amigos de la humanidad y de la patria. Y no contentos con estas medidas generales, son tantas las precauciones que toman algunos estados que el de Luisiana prohibió en diciembre de 1831 aun la introducción de otros esclavos procedentes de la misma unión Norte-Americana.

Ved aquí los pasos de un gran pueblo que busca su conservación, y ved aquí también el modelo que debiéramos imitar (228).

La extensa cita permite comprender cómo opera una de las aristas del discurso antiesclavista en Cuba: luego de Haití se extiende por el Caribe el temor a una sublevación. Por otro lado, Estados Unidos aparece como un modelo a seguir. Esta propuesta explícita de imitación debe leerse desde la clave de la modernidad americana marcada por la paradoja pues es una modernidad entendida no tanto como producto de un pasado sino como asimilación de las enseñanzas de la civilización que detentaba ese pasado: "Prestar, asimilar, apropiarse de luces ajenas permitiría constituir nuevas constituciones, nuevas leyes, nuevas costumbres" (Dávila 2005: 6).

Lejos de ser homogéneo, el discurso anti-esclavista reviste una complejidad de matices que se evidencian en dos estrategias argumentativas que acompañan la comparación: las preguntas y las concesiones. Mediante la primera, introduce en el artículo reflexiones y problemas. Y cuando la pregunta está concebida como retórica, también alberga en su formulación la respuesta. Por otro lado, las concesiones son múltiples y su uso se relaciona directamente con el lugar de enunciación del autor. Un lugar atravesado por tensiones, porque si bien es explícita la opinión negativa sobre el sistema de la esclavitud, al mismo tiempo, hay una meta-conciencia que le permite al autor ser consciente del lector esperado, aquel que adquiere la publicación por suscripción y que, en su mayoría, son los hacendados de mejor posición en la isla.

Pero en vano os empeñáis asi nos dirán muchos, en vano acriminais nuestra conducta: nuestras fincas necesitan de brazos y si solo encontramos negros $i a$ quiénes hemos de recurrir? Lejos de nosotros la intención de ofender a una clase tan digna de consideración y respeto, y entre cuyos miembros se hallan algunos a quienes tenemos le honor de dar el dulce nombre de amigos. Salvando pues la intención de los hacendados, nuestras funciones se reducen a decir que es forzoso adoptar otro partido, pues en la marcha que llevan los 
negocios políticos, el comercio ilícito de esclavos no puede continuar por tan largo tiempo (228).

Las concesiones exponen la demanda y la denuncia, pero también revelan el incómodo lugar del enunciador pues instalar el tema de la trata es provocar a quienes detentan el mayor poder político y económico de la isla, de ahí la necesidad de consentir parcialmente la práctica y ofrecer alternativas sustentadas en las experiencias en otras regiones. El ejemplo que citamos a continuación expone, además, la búsqueda de un pensamiento científico y racional que ayude a fundamentar los objetivos deseados a partir de un método basado en la experimentación y comparación de resultados:

¿Y no convendría que fuésemos haciendo algunos ensayos para ver la diferencia que hay entre el cultivo de la caña por esclavos y los métodos que podamos adoptar en lo adelante? Porque en este punto no hay más obstáculo que el interés; y si nuestros hacendados se pudiesen convencer de que sin el uso de esclavos sacarían mayores o iguales ventajas (...) Desearíamos pues que alguno dueño de ingenio destinasen uno, dos ó más cañaverales que desde la preparación del terreno para sembrar la semilla hasta el envase del azúcar producido por ellos, corriese a cargo de hombres asalariados y tomando en cuenta el tiempo que se emplea, la inversión y el interés de los capitales y todos los demás elementos que entran en cálculo en esta especie, se formará entre los dos métodos un paralelo que, ora favorable ora adverso, nos daría resultados ciertos (229).

En este tramo, el artículo sobre Brasil se torna excusa para hablar de lo que ocurre en Cuba. El amplio desarrollo del tema de la esclavitud que ocupa varias páginas genera un efecto de borramiento del texto base, es decir, del texto del presbítero R. Walsh que el autor comenta. Lo cual posibilita que emerja otro texto, el que elabora el comentador a partir de sus intervenciones y que revela los índices de la situación de la trata en Cuba. Con sucesivas intervenciones, puestas de manifiesto en relaciones, interrupciones y aclaraciones cada vez más extensas, el comentador se instala en el texto con una posición protagónica. Deja de ser comentarista de otro artículo, un lugar terciario, para desplegar una voz central que organiza el discurso. Cuando ocurre este traspaso, el lector ya no está frente al texto sobre las noticias de Brasil sino frente a un 
extenso desarrollo de la situación de la esclavitud en Cuba y los peligros que este régimen acarrea.

En toda esta secuencia predomina la voz del comentador que se advierte en exclamaciones, preguntas y asedios constantes, y si bien se desconoce el nombre, las marcas textuales posibilitan identificar esta voz con la de un autor/escritor cubano representante de la Ilustración, criollo y blanco. En síntesis, el anonimato autoral no genera un problema de identificación, al contrario, funciona como una estrategia retórica de clase, pues alude a un grupo específico que busca a través de la pluma configurar un nuevo escenario político-social.

Como ya señalamos, los artículos concebidos como reseñas tienen un aporte comentativo $^{81}$ que se distingue de las secuencias explicativas o descriptivas referidas al texto de origen. Por ejemplo, en el artículo que estamos citando se expone:

Después de haber trazado rápidamente el bosquejo histórico del Brasil, tiempo es que volvamos nuestra atención a su estado civil o doméstico; y sin seguir paso a paso al autor, entresacarémos aquellos pasages que inspiren más interés o que tengan más analogía con el país en que escribimos (190).

La inclusión de la voz del autor en el artículo pone de manifiesto la interferencia que realiza sobre el texto que traduce o comenta. El comentario propiamente dicho se plasma en juicios valorativos y en opiniones que explicitan posturas asumidas en relación al asunto tratado. Con esta intervención, la revista cumple con su objetivo de ofrecer una lectura mediada y experta sobre diferentes temas; en consecuencia, se presume que el lector podrá acceder a novedades y noticias de la isla y de otras latitudes en el tiempo breve, en relación a la complejidad y variedad de asuntos que demanda la lectura de los artículos.

Pero esta intervención ubica al autor en un lugar predominante de saber. No solo "recorta" el texto reseñado sino que, de manera reincidente, agrega información con el objeto de enriquecer el texto, corregir algún dato erróneo o bien señalar alguna relación con el ámbito cubano. En este sentido, los artículos cumplen con la función de divulgación y, al mismo tiempo, se presentan como verdaderos ensayos en los cuales

\footnotetext{
${ }^{81}$ Empleamos esta expresión según Núñez y Del Teso (1996).
} 
los escritores que colaboran en la edición ejercitan su función autoral y se legitiman desde ese espacio de escritura.

Pero si el ilustre Barón [por Walsh] hubiera avanzado sobre los años posteriores puesto que publicó su obra en 1826, entonces habría conocido su disculpable equivocación. Efectivamente, se ha observado de algunas años a esta parte, que cuanto mayores han ido siendo entre nosotros los bienes de la agricultura, tanto más se han disminuido los diezmos y este fenómeno que a primera vista es tan contradictorio depende de causas harto sencillas (192).

No es número el clero del Brasil. El obispado de Río es el que está mejor provisto de pasto espiritual, pues para una población de 800.000 personas tiene casi mil eclesiásticos. El Dr. Walsh dice que este número es escaso, más nosotros le juzgamos suficiente pues a casi 800 personas puede asignársele un ministro del culto (194).

En 1824 se fundó en Río de Janeiro una academia de Bellas Artes, en que se enseña la pintura, la escultura y la arquitectura. Aunque la instrucción es gratuita el número de alumnos es muy corto pero entre ellos se encuentran algunos que prometen mucha esperanza. Imposible nos es proseguir sin volver la vista a nuestra decadente Academia de Dibujo. Decadente, no porque se haya apagado en su digno director el entusiasmo que por muchos años ha ardido en su pecho (...) Decadente es porque sin recursos para sostenerse necesita de auxilios que la socorran y liberten de la muerte que la amenaza. ¿En dónde está la generosidad de los habaneros que ven perecen frente a sus ojos una de las instituciones que mas gloria y honor dan al suelo en que nacieron? ¿Dirá la historia algún día que nuestros grandes y ricos hombres, niegan con mezquina mano un corto donativo a la patria menesterosa? ¡Ah, no! Nosotros no podemos figurarnos que el historiador cubano esté condenado a consignar en sus obras una relación tan vergonzosa (197).

Los tres fragmentos transcriptos son muestras de intervenciones del autor que registran tonos distintos y en los cuales el rol del autor gravita en torno al saber. En el primer caso, el autor se configura como corrector y repara con su intervención el error. En el segundo caso, ofrece su opinión y como argumento recupera información presente en el texto original; la acción consiste, entonces, en "dar vuelta" la interpretación de los 
datos. En el tercer caso, la voz del autor interviene de manera crítica y además como denuncia. La pregunta resulta una estrategia que sirve para incorporar no solo su demanda sino también la respuesta que espera.

En todos los casos, la voz autoral aparece en escena mediando entre el saber y los lectores. De esta forma, se configura una imagen autoral que se legitima en la fórmula del "saber experto". En Del Monte, como en otros autores, se advierte que la racionalidad opera como rasgo distintivo. Esta cualidad se despliega y se refuerza a partir del lugar singular de enunciación que ocupan los escritores ilustrados como colaboradores en diferentes periódicos y revistas que se publican simultáneamente.

En el capítulo siguiente nos detendremos con más detalle en las figuraciones de autor que emergen en este ámbito cultural para entender la función de los letrados en el proceso de creación de un parnaso simbólico patriótico. 


\title{
Capítulo III
}

\section{La búsqueda del lenguaje patriótico}

\author{
Toda poesía \\ escrita por cubanos es \\ cubana pero no en toda ella \\ aparece la llama de \\ cubanidad que puede \\ distinguirla de la poesía \\ universal \\ Alberto Gutiérrez \\ de la Solana $(1988)^{82}$. \\ Otro vate más sublime \\ A quien inspire Minerva \\ Elogie lo que describo \\ Si el amor patrio le alienta. \\ Que yo absorto, meditando \\ De mi Cuba las bellezas \\ Me absorveré en contemplarlas, \\ Pues no puedo encarecerlas. \\ Francisco Pobeda \\ (Fragmento de romance, 1832) (33 $^{83}$
}

Los estudios literarios y culturales acerca del siglo diecinueve reconocen en la etapa de emancipación un punto crucial en el que se unen una serie de prácticas y discursos inaugurales que se corresponden con el surgimiento institucional del sujeto hispanoamericano (Moraña 1997). Aunque logre su independencia sobre el final del siglo, los cambios políticos, sociales y económicos que acontecen en el continente y del otro lado del Atlántico, impactan en Cuba y generan en el sector criollo letrado la necesidad de configurar una matriz simbólica identitaria diferenciada de la metrópoli. La función performativa, ética y pedagógica que se asigna al discurso político y

\footnotetext{
${ }^{82}$ Cita tomada del artículo de Alberto Gutiérrez de la Solana "La llama cubana de la poesía, desde el siglo XVII hasta Mart'”".

83 "Leyenda Segunda" en Feijoo 1977: 84.
} 
ficcional del período se inicia con los primeros intentos por fundar una retórica verbal e iconográfica que exprese este incipiente deseo de autonomía (Ramos 1996) ${ }^{84}$. En este vértice, eclosiona la preocupación por la búsqueda de un lenguaje nacional: ¿qué lengua y qué forma serían las más idóneas para expresar el ideario patriótico?

En las páginas precedentes hemos señalado la centralidad de la figura de Domingo Del Monte en la primera mitad de siglo, por eso, en este capítulo abordaremos, por un lado, su concepción de la lengua y la literatura, en relación al proyecto que alienta entre sus pares: la producción de un romancero cubano. Por otro, y en estrecha relación con la autoconfiguración de mentor de las letras cubanas, analizaremos las figuraciones de autor perfiladas en algunos de sus escritos.

\subsection{Cubanizar la lira: de la naturaleza al paisaje de la patria}

Cintio Vitier en Lo cubano en la poesía ([1957] 2002) entiende que hay dos maneras de pensar la cubanidad en la literatura. Una que denomina "externa", superficial, temática y, otra, que llama “interna", "de carácter esencial, secreta y oculta"85. Las coordenadas que rigen esta clasificación se encuentran profundamente arraigadas en el pensamiento "origenista" de Vitier ${ }^{86}$. No obstante, esta doble mirada de lo cubano nos permite pensar en el complejo proceso que implica la búsqueda de un lenguaje patriótico y la fijación de determinados modelos literarios que se consideran más aptos para vehiculizar este ideario.

\footnotetext{
${ }^{84}$ Julio Ramos (1996), en "Cuerpo, lengua, subjetividad" se detiene en analizar en la novela antiesclavista cubana, "los límites que demarcan —y al demarcar hacen posible — la configuración de un emergente de identidad" (23). Al respecto sostiene que la novela, por su heteroglosia cumple un papel clave en el proyecto de configurar una lengua nacional, pues ofrece un "mapa de la heterogeneidad lingüística de la sociedad cubana, que valora y jerarquiza los materiales con los cuales trabaja". En este sentido, La ficción representa los límites y la imposibilidad de la incorporación del habla del otro.

${ }^{85}$ En este apartado el uso de comillas indica expresiones tomadas literalmente de Cintio Vitier.

${ }^{86}$ La "teleología origenista" que supone un esencialismo "ese anhelo de las "esencias inatrapables", "aquello que late detrás" se opone a la "superficialidad" y la "carencia de finalidad". En esta tensión se despliega el programa origenista, en la búsqueda del hilo de continuidad histórica y cultural y de modelos creadores que resistan al influjo "desuntanciador". Ver Prieto, Abel (1996). En palabras del propio Vitier: "Siempre será provechoso el intento de ceñir y valorar lo que más genuinamente nos expresa en cada instante del devenir histórico. Cada generación, además, cada poeta, debe hacer su lectura de aquellos que lo precedieron. La poesía anterior no es un hecho inmóvil, sino que se va enriqueciendo e iluminando con su propia futuridad. También el pasado deviene. También en el pasado hay que poner nuestra esperanza y buscar nuestro futuro" (Vitier 2002: 57).
} 
Para Vitier, la cubanidad externa está presente en "lo fáctico y puramente nominal", en el "autoexotismo", en cierta "caricatura de lo cubano" que se manifiesta en las vertientes indigenistas o nativistas, como la poesía negrista, el Siboneísmo y el Criollismo, relacionadas con el Romanticismo y sobre las que volveremos más adelante ${ }^{87}$. En el marco de estas expresiones nativistas, Vitier sospecha del "tipicismo" con el que se presentan, pues para él opera de manera negativa (actúa como disfraz) y aleja la captación "esencial” de lo cubano.

Abel E. Prieto en “Lo cubano en la poesía. Relectura en los 90” (1996) ${ }^{88}$ observa que para Vitier estos trances de la literatura cubana marcada por lo externo componen una "instancia epidérmica", "superficial" y "efímera" y sostiene que las imágenes de "ornamento", "decorado" y "falsedad" le sirven al crítico cubano para pensar el vacío, la carencia de profundidad para abordar, en el caso de algunos poetas, en "lo hondo de los hechos". Es decir, mientras que en la superficie abunda de manera pintoresca "el artificio de la patria, la bandera y el himno" como un "decorado vacío", en lo profundo, "la cubanidad y la independencia son pura ficción" (2002: 10).

El proceso de construcción de la identidad en la literatura, "la cubanización de la lira", es paulatino. En una primera etapa, que abarca la poesía producida entre los siglos diecisiete y dieciocho, lo que se produce es un "acercamiento a la naturaleza insular", que es para el poeta, su realidad inmediata. Sin embargo, con atino distingue Vitier entre "realidad física" y "realidad poética" pues "aunque el hombre la sienta y la goce [a la naturaleza] el poeta no puede todavía expresarla sino a través de una concepción prestada y que es en sí misma, en la propia Europa, artificial y abstracta” (47).

\footnotetext{
${ }^{87}$ Para Vitier, estas tres expresiones son "nativistas", cada una de ellas pone el acento en un grupo étnico diferente: los siboneístas retornan al aborigen natural de Cuba, el siboney. Los negristas centrarán su mirada en el afrocubano, mientras que los criollistas revalorizarán la cultura del guajiro (criollo blanco). La búsqueda del sujeto que representa la cubanidad responde a intereses ideológicos y la configuración letrada que se realiza sobre cada uno de estos sujetos se enmarca en proyectos que involucran otros órdenes aparte del estético-literario: culturales, político-económicos, sociales, jurídicos, etc.

${ }^{88}$ Este artículo de Abel E. Prieto fue publicado por primera vez en la revista Temas, núm.6 abril junio de 1996 y luego como "Prólogo" de Lo cubano en la poesía en la edición del año 2002 de la editorial Letras Cubanas.
} 
Ya a fines del dieciocho y principios del diecinueve, el acercamiento poético a la naturaleza que realizarán los poetas cubanos será bajo la influencia de los escritores neoclásicos españoles como Leandro Fernández de Moratín (1760-1828), Gaspar Melchor de Jovellanos (1744-1811) y Juan Meléndez Valdés (1754-1817) quienes aportan, por un lado, modelos literarios grecolatinos tales como las odas, las silvas, las églogas, las elegías, los idilios y, por otro, un marco bucólico y una visión arcádica de la naturaleza, que se entronca en la tradición pastoril y anacreóntica. Sin embargo, este uso del neoclásico es ecléctico y, de manera gradual, posibilita la expresión poética de una naturaleza "cada vez más cubana" y menos bucólica. En esta tradición, se ubican, por ejemplo, la oda "A la piña" de Manuel de Zequeira y Arango (1764-1846), la "Silva Cubana" y la silva "Las frutas de Cuba" de Manuel Justo de Rubalcava (17691805), el idilio "El arroyo" de Felipe Poey (1799-1891) y la "Égloga cubana" de Gabriel Plácido de la Concepción Valdés (1809-1844).

Bajo la influencia de Andrés Bello se pasa de la fórmula pastoril neoclásica para cantar la naturaleza al poema didáctico-descriptivo (término que emplea Vitier) sobre la fauna y la flora de la isla. "Rasgos descriptivos de la naturaleza cubana" es una silva de 1831, de Francisco Iturrondo (1800-1868) que interpela a la silva de Bello "A la agricultura de la zona tórrida" (1826). Si bien Iturrondo escribe en circunstancias muy distintas a las de Bello, pues en Cuba aún no han comenzado siquiera las guerras de independencia, el autor cubano se apropia del mismo esquema para presentar el inventario de la naturaleza de la isla.

Cintio Vitier realiza la siguiente apreciación respecto de este proceso de interiorización de la naturaleza en la poesía:

En este proceso descubrimos una cierta espiritualización o jerarquía. Después de las frutas (paladar y olfato) aparecen los árboles y pájaros (mirada y oído). Se pasa, pues, de los sentidos más sensuales a los más espirituales. Entre las frutas, fue la piña el símbolo paradisíaco y vistoso, adecuado a la relegada voluptuosidad de la Colonia indiana. Entre los árboles, es la palma el símbolo ideal, erguido, anhelante, adecuado al despertar de la conciencia independentista (2002: 63).

Del mismo modo que Vitier plantea un proceso gradual de asimilación de lo cubano en la literatura que comienza con la naturaleza pero no se agota en este referente, 
podríamos aquí retomar lo postulado en el capítulo I de esta tesis, respecto de la configuración de la identidad. Al respecto, explicábamos que en el proceso identitario nacional es posible advertir un doble juego de inclusión / exclusión de distintos elementos que se corresponden con los siguientes órdenes de identificación: 1) la identidad territorial; 2) la identidad histórica; 3) la identidad cultural. En este sentido, la literatura expresa este proceso de diferenciación integrando en un imaginario común aspectos de la naturaleza, eventos de la historia y tipos sociales y sus costumbres. Sin embargo, esta representación no es transparente, sino, por el contrario, opaca, y requiere, por lo tanto, una lectura en capas, una lectura del revés de la trama. Bajo esta premisa, analizaremos el corpus de romances producidos por Domingo del Monte y otros escritores en el capítulo IV. Pero antes, consideramos oportuno y necesario desandar el derrotero delmontino por arribar a una forma estética idónea para expresar el nuevo ideario nacional, pues la búsqueda del lenguaje patriótico no está exenta de contradicciones.

Domingo del Monte y el grupo de escritores con los cuales intercambia valoraciones literarias, lecturas e ideas políticas transitan esta búsqueda del lenguaje patriótico, amarrados, todavía, a los modelos de creación literaria que ofrece la metrópoli. La necesidad de producir una literatura cubana que exprese el sentimiento criollo patriótico y que, al mismo tiempo, sirva de panacea para la formación de la identidad del pueblo, conduce a una producción poética que tematiza lo cubano, lo torna referencial. Para Vitier, es necesario el análisis particular para aislar en este período a los poetas que sí lograron una primera entronización de lo cubano en la poesía.

En el caso de Domingo del Monte, su actividad letrada es signo de una situación paradojal: el deseo de producir una literatura cubana y la imposibilidad de hacerlo, pues los medios retóricos, esto es, el trabajo en torno al lenguaje, van por detrás de ese anhelo. Al igual que sus coetáneos, su escritura oscilará entre el neoclásico y el Romanticismo. De modo que proponemos ver estas dos tendencias estéticas, no como usualmente lo hace la crítica, o sea, a partir de sus características contrastantes, sino como continuum de un proceso que acompaña la configuración de una identidad colectiva de carácter criollista. Es decir, las tradiciones literarias que 
preceden y, de alguna manera, convergen en el grupo delmontino son muy variadas, como ecléctico es el grupo en sí (tal lo analizamos en el capítulo II cuando abordamos la tertulia como un espacio singular de sociabilidad).

Cintio Vitier advierte que hacia las primeras décadas del siglo diecinueve la expresión poética se desplaza desde la poesía pastoril, bucólica y anacreóntica "con acentuado toque racionalista de procedencia francesa" (2002: 46) y la poesía filosófica, moral y didáctica de la Ilustración y la Enciclopedia hasta "una vivencia más sinceramente melancólica de la naturaleza propia del Romanticismo" (47). Estas vertientes fraguan en un proyecto cultural que articula esas tensiones ideológicas y estéticas: el romancero cubano decimonónico.

Para deslindar la compleja, y a veces contradictoria, posición de Domingo del Monte frente al Romanticismo como corriente que lo interpela, analizaremos en el siguiente apartado dos artículos de su autoría.

\subsection{Encrucijadas de la lengua, el estilo y la forma: tensiones en torno al Romanticismo}

José Lezama Lima en la Antología de la poesía cubana, siglo XIX (2000), distingue entre "poetas románticos", grupo que integra Del Monte y los "poetas populares", entre los cuales cita a Ramón Vélez Herrera, José Fornaris, Francisco Pobeda, Juan Cristóbal Nápoles Fajardo "el Cucalambé”. También para Cintio Vitier, tal lo postula en la “Quinta Lección” de Lo cubano en la poesía, como para Salvador Bueno (1999), Domingo del Monte representa al movimiento romántico costumbrista. Sin embargo, este "encasillamiento" merece una revisión o, al menos, una problematización que integre en esta mirada de la crítica cubana del siglo veinte, algunos elementos que otorguen espesor semántico a esta postura. Para ello analizaremos un corpus conformado por dos textos: "El poeta", publicado en El Aguinaldo Habanero en 1837, y "La poesía en el siglo XIX”, artículo publicado en El Álbum en 1838. Ambos textos recogidos por José Antonio Fernández de Castro (1897-1951) en su edición de los Escritos delmontinos. Repararemos en estas dos textualidades para trazar las líneas de la estética poética que alentaba Domingo del Monte, con el fin de establecer relaciones con el proyecto del romancero cubano. 
"El poeta" es un artículo de dos páginas en el cual Domingo del Monte expone los lineamientos centrales de su pensamiento literario: concepción de la virtud poética como don y estatus social especial del poeta. El artículo presenta un epígrafe que pertenece a Ramón de Palma, quien en una obra conocida como Cantares de Cuba, en 1854, señalará que “a él [a Del Monte] debemos el primer acorde de poesía verdaderamente local que ha producido la lira cubana", aunque estima que "el principal carácter de la literatura está en la lengua, de ahí que la poesía cubana, a pesar de guajiros y palmares, no es más que poesía española, así como esta no es más que las del Mediodía de la Europa, mezcla de la literatura clásica con las ideas de Oriente y las del Norte (Vitier 2002: 117). El mismo Ramón de Palma ha sido autor de numerosos romances. Los versos seleccionados en el epígrafe son el puntapié para que Domingo del Monte inicie su reflexión respecto del arte poético. En estos versos está presente la noción de poesía como don divino "solo el alma de un vate / en quien el cielo infunde / su rayo de luz gloriosa / sabe apreciar el amoroso anhelo / de una hermosa" (96). En el comienzo del texto, Del Monte asiente con tono de camaradería la afirmación vertida en estos versos: "Sí, mi querido B, solo un poeta, para cualquier otro hombre común vulgar, ordinario, aunque sea un conde, semejante mujer será siempre un enigma incomprensible". Sin embargo, este asentimiento es, en verdad, una concesión, pues en el segundo párrafo del artículo Del Monte aclara:

Pero por Dios, no tome usted por el poeta a que me contraigo a alguno de esos personajes ridículos, medio simples, medio relamidos, que persiguen sin compasión con sus insulsas coplas y sus mal o bien zurcidas consonantes al primero que encuentran; que rellenan con sus versos los periódicos, arrastran su desgreñada y tosca musa por bodas y bateos, por entierros y comilonas, haciéndola entonar roncamente elegías y epitalamios, laudes y misereres... (96).

Es decir, opone al verdadero poeta aquellos "personajes ridículos" que de alguna manera hacen de la poesía su forma de ganarse la vida: publican en los periódicos versos que "rellenan" espacios, o bien componen poesía "a pedido" para bodas, velorios y otros asuntos sociales. Para Domingo del Monte, Gabriel Plácido de la Concepción Valdés (1809-1844) es el poeta que encarna esta expresión utilitaria de la palabra poética. La relación "poeta/pan" está presente en el romance "Mi casa" en el 
cual Plácido evoca la voz del poeta pobre pero generoso: ¡No vio que el pan de un poeta / el que de morderlo trata / debe tenerlo primero / tres horas y media en agua! (56-60). Unos versos más adelante, hace explícito el intercambio de poesía por alimento u otras cosas:
No barro muy a menudo
Porque una vecina anciana
Me presta su escoba vieja.
Por eso y porque me llena
la botella, no hay mañana
que no me pida un soneto
para saludar a Odalla
a Rita, a Rosa, a Petrona
a Celestina, a Mariana...
pues un soneto chiquito
que así a las décimas llama $(65-76)^{89}$

Este rechazo a la mercantilización de la poesía es una marca del Romanticismo, sobre la que volveremos más adelante. En consonancia con esta postura, Del Monte considera que la poesía es un tipo de inteligencia especial con la cual se percibe el mundo y también lo trascendental. Dice:

El poeta no es porque haga versos, tal vez ni aún los hará, pero Dios le prodigó con larga mano los tesoros de la inteligencia y la sensibilidad. Su entendimiento clarísimo, percibe y abarca a una ojeada las verdades más ocultas y trascendentales de las ciencias a que se dedique (96).

Por eso, Del Monte insiste en dos rasgos que distinguen al poeta: fe y religiosidad, cualidades que lo enaltecen y lo colocan por encima de los hombres comunes. El artículo finaliza con una definición de poesía que se enlaza con la de poeta. La poesía es "todo lo hermoso en la naturaleza moral y física del mundo" (97), por lo tanto, el verdadero poeta es quien logra cantar esa belleza. La idea de poesía como canto es

${ }^{89}$ Romance publicado en Poesías de Gabriel de la Concepción Valdés, en 1886. Para entender el enfrentamiento entre Domingo del Monte y Plácido se sugiere la lectura del artículo de Ambrosio Fornet (2010) "El otro Plácido, sus editores y sus críticos". 
recurrente en la profusa escritura de Del Monte. Nos parece necesario reponer algunas nociones sobre la relación sinónima entre poesía y canto. Al respecto, Paul Zhumtor en Introducción a la poesía oral (1991) recurre a la tradición histórica para demostrar que fue originariamente la canción la forma por excelencia del discurso del arte verbal, pues la mayoría de las performances poéticas han sido cantadas, siendo en la voz cantada donde el lenguaje "exalta su potencia", donde la palabra se encuentra "magnificada":

La única forma poética que en todos los contextos culturales se presta a ello de forma masiva, inmediatamente accesible a la colectividad es la 'canción de amor' en la diversidad de sus retóricas, fijas y siempre re-inventadas: palabra fuera del tiempo y del espacio, acompasada con fórmulas tranquilizadoras cuyo paradigma es la llamada indecible del deseo; pero también, en todo momento, ruptura y nuevo impulso, voluntad de decir algo nuevo -de nuevo-. Alzada hacia un sujeto desconocido, imprevisible, una escucha vacía, la canción, por esto mismo, alcanza al receptor real, deseado, porvenir virtual del cantor, su Otro (1991: 171).

En el estudio pionero sobre "La primitiva poesía lírica española” ([1919] 1968) Ramón Menéndez Pidal afirma que "la lírica popular es siempre cantada" (162). En ese mismo estudio diferencia la poesía popular de la culta, agrega, además, la diferencia entre poesía popular y tradicional:

Hay cántigas populares pero no tradicionales pues la mayoría son obras de poetas cultos bien conocidos y, a pesar de su sencillez fundamental, tienen dejos de artificio, y no dan muestras de una elaboración verdaderamente popular. Alguna empero llega a nosotros con variantes tales que son signo de las refundiciones por las que una obra vive una vida tradicional en la boca de un pueblo (166).

Menéndez Pidal sostiene que la poesía lírica castellana se gesta en las "edades cultas y reflexivas", razón por la cual, es mucho más tardía que la poesía épica. Refiere el crítico español: "El caudal lírico de la Península aparece en el siglo XIII con los cancioneros gallegoportugueses y se continúa en el siglo XV con el cancionero gallegocastellano de Baena, en el cual aparecen las tres principales clases de canciones: cantigas de amor, cántigas de amigo y cántigas de escarnio y de maldecir" (162). Es en esta tradición gallego-portuguesa-castellana donde Menéndez Pidal sitúa el origen de la 
poesía lírica castellana. Villancicos, coplas, seguidillas, glosas son géneros cultivados por la poesía lírica, cada uno de ellos evolucionará hacia otras formas, "el villancico en seguidillas; la cuarteta en la copla; y la glosa de varias estrofas evoluciona hacia la monorrima, coincidiendo así con el romance, forma que procedente del mundo épico, invade cada vez más el campo de la lírica” (211).

Por otro lado, en la relación entre poesía y canto es ineludible la referencia a los Himnos homéricos, en los cuales un aedo (del griego oıঠós, aoidós, «cantor», que a su vez proviene del verbo $\varepsilon i ́ \delta \omega$, aeidoo, «cantar») entonaba el canto destinado a la deidad. Entonces, si por un lado, el canto está unido a la poesía desde la tradición homérica y, en la poesía castellana española, esta unión sirve para caracterizar a la lírica popular, no es casual que Del Monte use como sinónimos canto y poesía. Porque de esa manera resalta la función del poeta $\mathrm{y}$, al mismo tiempo, entronca en lo popular y en el romancero, pues desde su concepción de literatura como instrumento formador y moralizante, el poeta debe cantar para el pueblo y asumir en esa labor un rol edificante $^{90}$.

La función del canto y su relación con la configuración de la patria es abordada magistralmente por Josefina Ludmer en El género gauchesco. Un tratado sobre la patria ([1988] 2000). Su trabajo sigue siendo un faro teórico y un modelo de análisis para quienes abordamos las producciones literarias decimonónicas en esas regiones de Latinoamérica que — como señala Ludmer en el "Prólogo" a la edición del año 2000“ponen en relación la cultura oral y la letrada y usan la voz del otro". Por eso define al género gauchesco como un universo verbal, sonoro, “cuya sustancia es la relación entre voces oídas y palabras escritas". En este sentido, el género gauchesco "permite leer la forma que tomaban las relaciones entre lo oral y lo escrito y el espacio de la alianza o el anillo donde se unen" (2000: 9). En ese mismo "Prólogo", Ludmer comenta que uno de sus intereses era escribir un libro en el cual se abordaran tres sujetos y sus representaciones en torno al uso de su voz: el gaucho, el indio y el negro. Este último

\footnotetext{
${ }^{90}$ Las afirmaciones de Del Monte están avaladas por una extensa tradición épico-lírica occidental, retomada por el Romanticismo alemán, por ejemplo, Johan Gottfried Herder y los Volkslieder, y todo el debate que se desarrolla en torno a Volk Poesie (poesía popular) y Kunst Poesie (poesía del arte). Sobre esta discusión realiza una excelente aproximación Gloria Chicote en su Romancero (2012).
} 
abordado desde la literatura antiesclavista del Caribe. Aunque no escribe ese libro, sí explicita el plan: "El libro futuro quería ser también una historia de los problemas de los sujetos modernos, progresistas, que escribieron esas ficciones en el marco de la nación-estado. Analizaría los dramas de representación del escritor: generar subalteridades o sub-alternidades, hablar por el otro, hablar del otro, hablar el otro: usarle la voz, dársela" (2000: 10).

La perspectiva asumida por Ludmer permite una relectura ideológica que vincula los usos políticos del canto y la voz. También en su análisis es central la noción de "tono" para comprender las alianzas entre voz, letra y cuerpo, las cuales permiten reflexionar sobre los usos letrados de la voz popular ${ }^{91}$.

En el segundo artículo que proponemos analizar, "La poesía en el siglo XIX", publicado al año siguiente en $\mathrm{El}$ Álbum ${ }^{92}$, Del Monte retoma y explaya algunas de las nociones vertidas en "El Poeta", pero lo hace con un tono más enfático, por lo cual podría leerse este artículo como un manifiesto delmontino. Sobre este rasgo textual nos detendremos más adelante.

Tal cual el uso sinónimo entre canto y poesía al que hacíamos alusión, el primer párrafo del artículo se inicia con una afirmación: "La condición del poeta sobre la tierra es cantar". Ese "cantar" encierra para Del Monte la idea de comunicar a otros una verdad que solo ve el poeta. Del Monte aclara que solo el poeta puede "revestir" de una "novedad indefinible" aquellos objetos sobre los cuales canta.

La idea respecto de que el "ingenio creador" del poeta es "la prueba triunfante y decisiva de que la mente humana es un rayo, una emanación inmediata de la mente soberana de Dios", se expande en el artículo y refuerza la noción de religiosidad y moralidad que deben caracterizar al binomio poesía-poeta. "El poeta nace", afirma contundente Del Monte al comienzo del segundo párrafo, puede "pulirse y formarse" pero el arte poético es un "don gratuito del cielo" (85). Lo que hace el poeta es

\footnotetext{
${ }^{91}$ Julio Schvartzman en Letras gauchas (2013) revisa la tradición literaria y crítica en torno al género gauchesco y piensa en dos mecanismos que obturan la lectura de este género: "populismo" (aquellos que sostienen una esencia gaucha oral) y "elitismo" (aquellos que suponen únicamente una apropiación letrada). Desde su perspectiva, la gauchesca es vista como un territorio en el que se hacen presentes de manera particular problemáticas entre oralidad y escritura de carácter universal.

${ }^{92}$ El Álbum, La Habana, 1838, Tomo II. 5-19.
} 
transformar aquello que ve y siente "fraguar con su imaginación" para devolver al mundo sus creaciones que son "figuras palpables, en realidades cuasi, tan animadas como los objetos mismos que vemos y tocamos diariamente, y aún mas gratas y apacibles para nosotros, porque sentimos cierto noble orgullo en pertenecer a la misma raza del ente semidivino que ha sido capaz de producir semejantes maravillas" (86). En este segundo apartado, una lista de grandes poetas de la historia (Homero, Ariosto, Cervantes, Calderón, Milton, Richardson, Walter Scott) emerge como referencia para fundamentar la idea de que en todos los tiempos los poetas cantaron las grandezas del mundo.

El tercer párrafo irrumpe con una pregunta que instala el tema central de la exposición y que agrega un elemento importante no desarrollado en el artículo "El Poeta”. Se trata de la noción de temporalidad expresada en la concepción del presente como un momento histórico particular:

Ahora bien: el hombre, dueño de facultad tan maravillosa ¿no será responsable del que haga de ella y hoy principalmente? Sabedor el poeta del estupendo influjo que en la muchedumbre ejercen los principios morales que profese en sus ficciones, ¿no tendrá derecho la sociedad en que viva de tomarle en cuenta del uso que haga como hombre de su ingenio, así como lo tiene la crítica literaria para pesar el mérito que como artista tenga en sus obras?

Sí lo tiene, porque el poeta no es un ser aparte de su especie; porque, a pesar de que ocupa el grado más alto en la escala de las criaturas humanas, por el privilegio imprescriptible que le da su claro entendimiento (...) no es un morador del cielo, pertenece aun a la humanidad, a ella van a buscar eco sus himnos (87).

La formulación en términos retóricos de la pregunta y de su inmediata respuesta revela el pensamiento racional de Del Monte, y al mismo tiempo, contiene una de sus mayores preocupaciones literarias que es la del poeta y su relación con el medio, es decir, su concepción del poeta como un hombre de su tiempo y de su tierra, un sujeto que debe ser consciente de la influencia que su palabra ejerce sobre "la muchedumbre".

El fragmento citado también nos permite formular dos problemas que modulan el Romanticismo: uno de ellos es la concepción social de la literatura en 
relación con la temporalidad y la contemporaneidad; y el otro, la nominalización de "lo popular" en acepciones como "el pueblo", "la plebe", "la muchedumbre".

El poeta que "ocupa el grado más alto en la escala de las criaturas humanas pertenece a la humanidad". Este "pertenecer" tiene dos instancias de fijación: la temporalidad y la espacialidad. Estos dos aspectos han sido objeto de reflexión en el Romanticismo. Al mismo tiempo nos parece posible vincular esta relación de "pertenencia a la humanidad" con la noción de "contemporaneidad" que desarrolla Giorgio Agamben ${ }^{93}$, quien la define como:

una singular relación con el propio tiempo, que adhiere a él y, a la vez, toma distancia; más precisamente, es aquella relación con el tiempo que adhiere a él a través de un desfasaje y un anacronismo. Aquellos que coinciden demasiado plenamente con la época, que encajan en cada punto perfectamente con ella, no son contemporáneos porque, justamente por ello, no logran verla, no pueden tener fija la mirada sobre ella (1).

Además, para Agamben, la mirada del contemporáneo tiene otra cualidad:

Puede decirse contemporáneo solamente quien no se deja enceguecer por las luces del Siglo y alcanza a vislumbrar en ellas la parte de la sombra, su íntima oscuridad. Con esto, sin embargo, no tenemos aún la respuesta a nuestra pregunta. ¿Por qué alcanzar a percibir las tinieblas que provienen de la época debería interesarnos? ¿No es quizás la oscuridad una experiencia anónima y por definición impenetrable, algo que no está dirigido a nosotros y no puede, por ello, concernirnos? Al contrario, el contemporáneo es aquel que percibe la oscuridad de su tiempo como algo que le concierne y no deja de interpelarlo, algo que, más que toda luz, se dirige directamente a él. Contemporáneo es aquel que recibe en pleno rostro el haz de tiniebla que proviene de su tiempo (3).

Algo del orden de esta contemporaneidad se deja apreciar en las palabras de Domingo del Monte. De hecho, muchos escritores decimonónicos han manifestado en poemas y

\footnotetext{
${ }^{93}$ Un taller dictado por la Dra. Mónica Marinone en el ámbito de las jornadas Katatay 2014 me ha ayudado a pensar esta relación. En ese encuentro se discutió sobre el artículo de Giorgio Agamben (2008) “¿Qué es lo contemporáneo?”.
} 
en ensayos esta mirada enrarecida del mundo, de "desfasaje y anacronismo" propias del sujeto contemporáneo.

Ahora bien, ¿cómo se inscribe la relación con el tiempo y con el espacio desde el Romanticismo? ¿Qué lugar ocupa el poeta en esta diatriba? Michel Löwy y Robert Sayre (2008), revisan la configuración del Romanticismo en relación con el sistema capitalista moderno, engendrado por la Revolución industrial y la generalización de la economía de mercado. Su tesis central es que el Romanticismo, en todos los campos, expresa el rechazo al individualismo que propone la vida moderna. En contrapartida, la rebelión y la melancolía emergen como reacción a la "modernidad". Pero ¿qué aspectos de la Modernidad rechaza el Romanticismo? Los románticos reaccionan contra "el espíritu de cálculo", "el desencanto del mundo", "la racionalidad instrumental", "la dominación burocrática", aspectos considerados por Löwy y Sayre “inseparables del advenimiento del "espíritu capitalista" (29).

Cuando Del Monte en su artículo hace referencia a la "responsabilidad del poeta" y marca con itálica la palabra "hoy" está, de algún modo, llamando la atención sobre esa realidad. Retomamos aquí las palabras de Del Monte cuando desprecia a los poetas que venden su poesía para “ganarse el pan”. En esta reacción se advierte cómo se gesta en la sensibilidad romántica cierto impulso anticapitalista, que puede ser más o menos consciente. Pues un aspecto importante que destacan Löwy y Sayre es que "el Romanticismo es, quiérase o no, una crítica moderna de la modernidad. Es decir que, aun rebelándose contra su tiempo, los románticos no podrían dejar de estar profundamente afectados por él (2008: 32).

Otro de los rasgos del Romanticismo que se advierten en Del Monte es lo que Löwy y Sayre definen como "la convicción dolorosa y melancólica de que al presente le faltan ciertos valores humanos esenciales que fueron alienados" (32). En este sentido, la mirada romántica se vuelca sobre los vínculos y los medios de producción. Se manifiesta la melancolía o nostalgia por un pasado pre-industrial o pre-capitalista, o al menos, por un pasado en el que el sistema socioeconómico moderno no esté plenamente desarrollado. Según esta observación, se puede comprender mejor la recuperación que realiza Domingo del Monte del guajiro como emblema nacional, pues su figura remite a un universo rural, no invadido por la industria del ingenio ni 
contaminado por el negro-esclavo, que será visto por Del Monte como un elemento del sistema de producción capitalista e industrial que impone la factoría. No obstante, como ya hemos analizado en los capítulos precedentes, el posicionamiento ideológico y discursivo de Domingo del Monte es muy complejo y esto que llamamos "visión romántica" es una las múltiples aristas que lo atraviesan, más no la única, razón por la cual debemos problematizar cualquier intento de saturación conceptual.

También nos interesa destacar en este artículo el rol activo que Del Monte le concede a la sociedad en relación a estos hombres privilegiados con la palabra. Los poetas podrán ser juzgados tanto como hombres como por su calidad artística. La idea de que la ficción debe tener algún valor moral, alguna enseñanza y que, por lo tanto, debe contribuir a la edificación de las virtudes en los lectores es un señalamiento constante y diseminado en diversos textos de Domingo del Monte. Este signo de "prodesse et delectare", o de la literatura como exempla (típico del Medioevo) lo conduce a buscar modelos literarios dignos de imitación en las expresiones realistas del drama y de la narrativa europea y estadounidense. Además, es posible pensar este valor moral y social de la literatura en relación a ciertos postulados románticos que proclaman un "reencantamiento del mundo". La vuelta al mito y a las religiones precapitalistas permite encauzar en los románticos el sentimiento de rechazo a la era industrial y al principio acumulativo. Como sostienen Löwy y Sayre "una de las principales modalidades románticas de "reencantamiento del mundo" es el regreso a las tradiciones religiosas, y a veces místicas (...) Más allá de que existe un Romanticismo arreligioso e incluso antirreligioso, es cierto que la gran mayoría de los románticos — sobre todo de comienzos del siglo XIX - buscan apasionadamente restaurar las religiones del pasado, y en particular el catolicismo medieval" $(41)^{94}$. Pero la religión no es el único medio de reencantamiento que eligen: se vuelven también hacia la magia, las artes esotéricas, la hechicería, la alquimia, la astrología; redescubren los mitos paganos o cristianos, las leyendas, los cuentos de hadas, los relatos "góticos"; exploran los reinos ocultos del sueño y lo fantástico. Entre las estrategias románticas,

\footnotetext{
${ }^{94}$ Löwy y Sayre ejemplifican con el texto político-literario de Novalis, L`Europe ou la Chrétienté esta religiosidad romántica teñida de nostalgia, que por su sensibilidad estética y su poesía mística, se diferencia de los dogmas institucionalizados de la Iglesia.
} 
el recurso al mito ocupa un lugar aparte. En la intersección mágica entre religión, historia, poesía, lenguaje y filosofía, el mito ofrece un reservorio inagotable de símbolos y alegorías, de fantasmas y demonios, dioses y serpientes. Según Löwy y Sayre, "hay muchas maneras de abrevar en ese peligroso tesoro: la referencia poética o literaria a los mitos antiguos, orientales o populares, el estudio "académico — histórico, teológico o filosófico - de la mitología, y el intento de crear un nuevo mito. En los tres casos, la pérdida de sustancia religiosa del mito lo convierte en una vía no religiosa para recuperar lo sagrado" (43).

Si la religiosidad entronca en el Romanticismo, cierto carácter moralizante que Domingo del Monte le atribuye a la literatura puede asociarse a los principios de la Ilustración (aunque también hay posturas románticas que moralizan). En este sentido, debemos pensar en una continuidad entre Ilustración y Romanticismo, pues hay un vínculo innegable entre Ilustración y burguesía ${ }^{95}$. Según el planteo conceptual que realizan Löwy y Sayre, Romanticismo e Ilustración coexisten en todos los siglos de la modernidad, desde el dieciocho hasta el siglo veinte. Pero es necesario deslindar posiciones, discernir y organizar en ciertas configuraciones típicas su diversidad pues “el vínculo entre los diferentes Romanticismos y el espíritu (o los espíritus) de la Ilustración no es constante" 68). Encontramos — dicen los autores que seguimos"todo tipo de mezclas, de articulaciones, de yuxtaposiciones, de titubeos y de pasajes entre las dos perspectivas, divergentes pero no totalmente heterogéneas. Admitamos pues la diversidad de los vínculos entre Romanticismos e Ilustración” (69).

Señalamos en el artículo que analizamos — "La poesía en siglo XIX”- el uso de las palabras "muchedumbre" e "influjo" pues se relacionan con aspectos ya desarrollados en el capítulo anterior que remiten a la certeza de Del Monte respecto de la necesidad de educar a la población, pues una población sin educación es una "masa revoltosa" que hace peligrar el equilibrio social. En la elección del concepto "muchedumbre" se advierte una valoración, pues es inespecífico y peyorativo, pero al mismo tiempo, esta masa humana es para Del Monte vital porque es la que se deja

\footnotetext{
${ }^{95}$ Por lo general, la oposición se plantea en términos de Romanticismo / Neoclasicismo. No obstante, la Ilustración como tal excede, pues abarca y contiene, al Neoclasicismo, aunque éste no debe considerarse como la única expresión de la Ilustración. Sobre "Clasicismo" y "Neoclasicismo" ver Hauser (1969); Rest (1979); Aguiar e Silva (1984); Fernández (2008).
} 
influir por las ficciones. Las ficciones, entonces, deben contribuir a la formación moral (es decir, no despertar el goce de experiencias ajenas ni dar mal ejemplo) y a la formación metafísica (no faltar a la verdad de las cosas, ni falsear la realidad) ${ }^{96}$. Por otra parte, el término "muchedumbre" expresa la existencia de ciertas condiciones sociales. En el caso de Cuba, la preocupación por una masa demográfica — la de color - que ha crecido muy rápido y de manera sostenida, como consecuencia de la importación de esclavos africanos, genera preocupación en los sectores letrados representantes de la Ilustración. Al respecto, podemos señalar como antecedente de esta preocupación, el intento de reforma de la administración local en Cuba, impulsada por Salvador José Muro y Salazar, conocido como Marqués de Someruelos, quien gobernó Cuba entre 1799 y 1812. El gobernador Someruelos proponía crear una tercera gobernación (existían dos, la de La Habana y la de Santiago de Cuba, supeditada política y militarmente a la primera) pues "debido al progreso de la población y la economía, a que la isla se hallaba rodeada de colonias extranjeras y por las muchedumbres de las gentes de color que hay, tanto libres como esclavos", era conveniente subdividir la isla en tres poderes políticos y militares (Someruelos citado en Amores Carredano 2005: 68).

Durante el siglo diecinueve hispanoamericano, la muchedumbre y su tratamiento será un problema a resolver en el afán de construir estados modernos “civilizados". En el caso de Cuba, si bien su colonialidad se extiende hasta finales del diecinueve, los cambios demográficos, sociales y culturales que trae aparejada la poderosa economía de plantación genera que los letrados lancen interrogantes sobre la inquietud que genera "la masa" y "la muchedumbre". La Psicología Social de finales del diecinueve, por otra parte, aportará a esta problemática un campo disciplinar específico bajo el cual se indagarán estas configuraciones sociales. La obra que organiza la órbita de estudios es Psicología Social de las masas de Gustave Le Bon (1894). En el caso de Cuba, es central la figura de Enrique José Varona (1849-1933) quien otorgó al Positivismo spenceriano una impronta local y usó esta ciencia para

\footnotetext{
96 En relación a esto, uno de los trabajos más interesantes sobre la lectura y sus prácticas en Occidente es el de B.W Ife (1992), La ficción a juicio. En él, el autor desarrolla los cuatro alegatos platónicos contra la ficción: dos de índole moral y dos de índole metafísica, que recobran valor frente a las prácticas de lectura silenciosa y el nuevo status de la ficción en el Siglo de Oro Español.
} 
pensar la herencia hispánica como signo de "barbarie" y promover la independencia "mental" del cubano como paso ineludible para luego lograr la independencia política $^{97}$.

Mientras que el término "muchedumbre" alude a una masa indefinida pero al mismo tiempo connotada de manera despectiva y asociada a lo "peligroso" y a la "gente de color"; la denominación "pueblo" tiene otras connotaciones que rozan lo popular con lo folklórico y ligan el concepto a lo telúrico, a lo originario. Ambas denominaciones remiten a paradigmas conceptuales y disciplinares diferentes, pues, por un lado, el término muchedumbre ha sido incorporado como categoría en las ciencias sociales de corte naturalista y positivista. En tanto que ha sido el Romanticismo el cuerpo filosófico que alberga la noción de "pueblo" en relación a lo local.

En referencia al planteo cultural que subyace en el empleo de estas denominaciones, podemos advertir en el artículo de Del Monte cómo en el cuarto párrafo se incorpora una pregunta bajo la cual se organiza el núcleo temático del texto: “¿Cuál es la misión del poeta castellano, concretándonos a la época actual y a los tiempos trabajosos que ha alcanzado la gran familia española?” (88). Esta pregunta nos sirve al mismo tiempo para organizar algunos aspectos que venimos desarrollando y que tienen que ver con la concepción lingüístico-literaria que opera en Del Monte, las tensiones con las estéticas vigentes y el rol del poeta/escritor en el entramado cultural de la sociedad. Al respecto, notamos que en el interrogante desplegado se explicita la concepción cultural delmontina respecto de la "familia española". En indudable que Cuba es parte de esa familia por lazos idiomáticos. Si bien esta idea ya ha sido desarrollada en el capítulo I, este artículo resalta con ímpetu la condición filiar —a veces España es "madre", otras "hermana"- según sea el espíritu emancipador que

\footnotetext{
${ }^{97}$ Dice Varona: "El día en que de la inspección de las condiciones fisiológicas y de los datos psíquicos personales podamos deducir científicamente el carácter de un individuo; es decir, cómo reaccionaría en el mayor número de casos contra los estímulos del medio en que se encuentra sabremos positivamente lo que hasta ahora ha estado la humanidad haciendo a tientas. Sabremos educar". El positivismo ofrece estos medios. "Esta psicología tan pobre, al parecer, que se limita a describir los estados mentales (...) y a investigar sus leyes nos abre de súbito tales perspectivas que palidecen ante ella las ciencias que con razón se han titulado, hasta aquí, las mejores amigas del hombre”. Ver Leopoldo Zea ([1976] 1965: 144$163)$.
} 
encarne el vocero cubano. Pero lo importante es que siempre se registra el lazo castellano como un vínculo insoslayable. De hecho, si reparamos en la correspondencia política de Domingo del Monte su discurso se pronuncia siempre a favor de la monarquía española, marcando la inmadurez del pueblo cubano para asumir “abruptamente" el propio gobierno (tal sería el resultado de una revolución), por eso es partidario de un reformismo político paulatino, de una separación "lenta" de la metrópoli aunque sí vela por un gobierno de la isla que no sea despótico ni injusto ${ }^{98}$.

El otro aspecto es la conciencia epocal de Del Monte. En este sentido, para el cubano el momento histórico es "trabajoso" y está cargado de urgencias, de demandas. Si bien estas premisas son constantes en la textualidad delmontina, el tono categórico e imperativo hace de "La poesía en el siglo XIX" un artículo programático y lo torna casi un manifiesto. Si hay aspectos que permiten restringir esta afirmación son, justamente, el carácter racional del artículo y la exposición cuasi pedagógica en algunos tramos. Está organizado en secuencias explicativas en las cuales predominan construcciones de causa y consecuencia que despojan al texto de afirmaciones caprichosas. Aunque el discurso esté cargado de sentencias, cada una de éstas se desarrolla, fundamenta y explica. Del Monte no deja ideas al azar, por el contrario, hay en los textos delmontinos un énfasis puesto en lo racional que impide la saturación expresiva puramente romántica. O dicho de otra forma, para cada una de esas expresiones valorativas encerradas entre signos de exclamación hay destinada una secuencia descriptiva, explicativa o argumentativa que opera sobre la interpretación del todo textual.

En cuanto a su posicionamiento estético-ideológico, si bien en las páginas anteriores hemos explicado su posición y analizado parte de su discurso en función de un anclaje en el Romanticismo, advertimos que en este artículo, Del Monte asume una

\footnotetext{
${ }^{98}$ Ver, por ejemplo, la correspondencia política entre 1836 y 1838 a Salustiano de Olózaga (1805-1873), en la cual Domingo del Monte le pide a éste que en carácter de diputado en las Cortes de Cádiz interceda en favor de José Antonio Saco en el enfrentamiento con el Capitán General de Cuba, Miguel Tacón. En las cartas, Del Monte apela varias veces al "patriotismo" y a la razón de que Cuba es también española y que dependerá de los capitanes generales que la metrópoli designe el futuro de la isla, en clara alusión al enfrentamiento que él también tiene con Tacón a partir del episodio con Saco y la Revista Bimestre Cubana. Las cartas completas pueden consultarse en la edición digital de los Escritos de Domingo del Monte.
} 
postura más explícita frente a esta corriente (o al menos, contra un "sector" del Romanticismo). Cuando explica el carácter de la época y para hacerlo recurre a la personificación de España como un niño "candoroso, ingenuo", "adormilado" que de pronto ha despertado a la "violenta invasión estranjera" hace referencia a la invasión cultural y filosófica que tiene a Voltaire a la cabeza. Una invasión carente de religiosidad y fe y llena de "tormentos intelectuales y morales" (90). Dice Del Monte:

De aquí resulta que franceses, españoles e italianos atraviesan todos por un perdurable devaneo, y ni aun saben lo que han de desear; que, en medio de la desvergonzada behetría de ideas y sentimientos en que se agitan los ánimos, y por entre el adulterio, la crápula y todo linaje de torpe sensualidad, aparece y se levanta el suicidio como último e irremediable síntoma del cáncer que devora y corroe a la sociedad" (90).

Y continúa:

Fieles representantes de esta angustiosa crisis son en Francia los famosos Dumas, Jorge Sand, Balzac, Alfredo de Vigny y otros muchos que en sus obras nos ofrecen un contraste verdaderamente lamentable, pues se ven los más hermosos y brillantes destellos del ingenio humano sirviendo de intérpretes a la más desenfrenada y repugnante concupiscencia. En nuestra España los poetas que más se han distinguido entre sus jóvenes compañeros por las felices y acabadas producciones de su talento, Larra y García Gutiérrez, tienen también el sello de maldición que distingue a esta literatura de réprobos, copia y modelo a la vez de la corrupción de las costumbres" (91).

En los pasajes seleccionados se advierte el tono sentencioso y de rechazo al Romanticismo como expresión de una crisis de la humanidad que Del Monte entiende es, ante todo, moral. Si reparamos en la serie de adjetivos y sustantivos que emplea el autor para denominar este estado epocal, arribaremos a la elaboración de un doble campo semántico. Por un lado, la configuración de un escenario maligno o demoníaco y por otro, la referencia a lo obsceno y a la carencia de moralidad. Estos campos se superponen y juntos dan lugar a un tercer campo semántico, el de la enfermedad, que le permite a Del Monte definir y sintetizar el "mal de época”. Sin embargo, el propio Del Monte, lejos de purismos, se ocupa de explicitar:

Y no se diga, como lo repiten a coro sin reflexión, someros e irreflexivos críticos, que la culpa de todo la tiene la fórmula literaria, que con el nombre de 
Romanticismo han adoptado los jóvenes literatos franceses y españoles: nada tiene que ver el modo artístico de hacer una novela o un drama, con la esencia de las ideas morales que en ellos se determine: nadie es más inmoral y obsceno que el clásico Voltaire en sus Cuentos filosóficos ni más puro y moral que Manzoni, jefe de la escuela romántica italiana (91-92).

Esta cita indica, por otra parte, la distinción crítica que realiza Del Monte respecto de los autores que le son contemporáneos y el elemento enfático que define la buena literatura: el efecto moralizador. En este sentido, la postura de Del Monte mantiene puntos de contacto con el Neoclasicismo y su tendencia al principio del decoro, la ejemplaridad y la moralidad. Retomando la tensión entre Ilustración (con la manifestación del Neoclasicismo) y Romanticismo, quien analiza el funcionamiento de estas dos perspectivas en la configuración de las nacientes repúblicas en América Latina es Graciela Montaldo, cuando a propósito de Bello y Sarmiento, afirma:

La literatura latinoamericana se funda como tal (con conciencia de su particularidad y su diferencia respecto de su natural vínculo con España) a partir de las redes culturales que se establecen luego de la Independencia; es en ese momento en que comienzan a estructurarse los proyectos para el futuro con los que se pretende integrar nacionalmente a los ciudadanos de cada país o región; es también el momento en que la cultura como cemento de unión de los rasgos nacionales y los intelectuales como portadores de una tarea política al servicio de las nacientes repúblicas, se consolidan. Estamos fijando un origen, núcleo de varios problemas modernos y un momento histórico en el que confluyen varias perspectivas, ya que esa fundación se produce en un período en que dos paradigmas culturales están conviviendo en nuestros intelectuales: la filosofía de la Ilustración por un lado; la nueva percepción romántica del mundo y de la subjetividad, por otro (1995: 107).

Si bien, en Cuba, en el mismo período, la independencia es todavía un proyecto lejano, el "núcleo de problemas modernos" en relación a la gobernabilidad de una población heterogénea y al rol de los letrados, es visible en Cuba, pues tal como advierte Víctor Goldgel (2013), la situación de "modernidad" singular que reviste a Cuba en la primera mitad del siglo diecinueve posibilita trazar comparaciones entre la isla caribeña y la región del Cono Sur (Chile y Argentina). 
Para explicar la lógica que relaciona estas dos perspectivas, Montaldo sostiene que, por un lado, la Ilustración será la portadora de un modelo de lo que la cultura es, estableciendo valores universales, racionalistas y paradigmáticos. Permitirá además, unir los cuerpos: el "nuevo"/ americano, con el de la "madre"/España, a partir de tópicos en una retórica que articula la tradición del nuevo territorio y el establecimiento de nuevos vínculos, con la Antigüedad Clásica y la variedad del locus (1995: 108). Por otro lado, lo romántico se superpone a lo ilustrado en la formación intelectual de los letrados, y conformará

Un filtro cultural que deconstruya y rearme lo que desde la perspectiva ilustrada se propone a la sociedad. Desde el punto de vista literario, la percepción romántica disuelve muchas de las certezas del orden científico anterior y va creando las nuevas pautas para pensar el mundo (ideas como patria, pueblo, tradición cobran desde entonces un valor inusitado, por inédito y la escritura sirve para expresar la nueva mirada sobre el mundo) (108).

Podemos considerar la pregunta que formula Del Monte una síntesis entre dos perspectivas: ¿Qué tiene que hacer, pues, en medio de esta sociedad, en esta época, cuyo carácter acabamos de bosquejar, un verdadero poeta castellano, de voz armoniosa, de corazón ardiente y mente pensadora? (92).

En primer lugar, dice que no puede ser solo un servil imitador de modelos incompletos y que tampoco debe renunciar a la "inapreciable nacionalidad de su ingenio, dote que le da mayor y más original realce" (92). La respuesta que ofrece se encabalga en esta superposición que plantea Montaldo, por un lado, una nueva mirada del mundo, que registra lo peculiar, la originalidad del poeta y que hace de libertad un estandarte: el poeta como héroe; por otro, referencias a la "pulcritud" a "un orden fijo de ideas", remiten a la moralidad y al didactismo más propio de la Ilustración. En Del Monte convergen y se superponen estos principios, generando un discurso cuyas fisuras ponen en evidencia esta ardua convivencia paradigmática $\mathrm{o}$, en términos de Agamben, su "contemporaneidad".

\section{Del Monte responde a la pregunta:}

Él mismo será su escuela: él se formará su estética peculiar, sin cuidarse de clásicos ni románticos, rancia nomenclatura que ya pasó y que de nada sirve; hará que la lengua castellana resplandeciente como el oro puro, y sonora como 
la plata y en toda su pulcritud, pero también en toda su libertad, sirva de magnífico engaste a sus concepciones...Estas no serán hijas del acaso, ni abortos informes de una mente ociosa y sin cultura, sino frutos necesarios y consiguientes de un orden fijo de ideas (92).

Los últimos dos párrafos del artículo convocan al poeta a asumir su "verdadera misión" en el siglo diecinueve, "un siglo de ideas graves": la de ser hombres que contribuyan "a mejorar la condición de sus semejantes, generalizando entre ellos ideas exactas y sanas de moralidad" (94). Para ello, Del Monte exhorta al poeta a que "el mismo sea su musa y su héroe" (94). Una de las claves del artículo reside en esa frase final que sentencia que "el poeta debe ser su propia escuela", en el llamado a concebir la peculiaridad y la nacionalidad como signo de originalidad.

Por otra parte, el Romanticismo también ha contribuido a pensar la noción de autor pues a partir de él se establecen tres criterios que giran alrededor de esta noción: subjetividad, originalidad y creación (Altamirano y Sarlo 1983). En función de los postulados sobre el valor del poeta/escritor, nos preguntamos sobre las figuraciones autorales que identifican la práctica letrada en Domingo del Monte. En el apartado siguiente nos ocuparemos de analizar un corpus mínimo - que entendemos- nos permite aproximarnos a este núcleo problemático $\mathrm{y}$, dado que el corpus también lo permite, iniciaremos algunas reflexiones en torno a la elección del romance como género escogido por Del Monte para expresar el ideario patriótico.

\subsection{Figuraciones de autor: Domingo del Monte y la construcción de la ejemplaridad}

Casi todas las actividades culturales en Cuba enmarcadas en la década de 1830 a 1840, con pocas excepciones, gravitan en torno a Domingo del Monte. ¿Cómo construye su figura de autor? ¿Qué mecanismos de legitimación lo avalan? ¿Qué máscaras revisten esa construcción autoral? Si bien en las líneas precedentes hemos anticipado algunos elementos que definen la función autoral, en este apartado proponemos situar la reflexión sobre las figuraciones de autor en función del análisis de dos textos: el "Prologo" de Rimas americanas, de 1833, y una carta que le escribe José Jacinto Milanés a Domingo del Monte en 1836. 
La elección de este corpus mínimo se excusa en la mirada espejo que proponemos. Con esto queremos indicar un doble juego que opera en la construcción de la subjetividad del autor: verse a sí mismo y ser visto por otro. Mientras que las Rimas americanas ofrecen la primera visión, la carta, al situarlo como destinatario, ofrece la segunda. Sin dudas, median en estas construcciones otras reglas, las propias de la textualidad que las vehiculiza. No obstante, repararemos también en la condición textual que plasma la voz del autor, ya sea en presencia o en referencia. En nuestro análisis comenzaremos por las figuraciones de autor que se elaboran en la carta, pues las del "Prólogo" presentan una construcción de enmascaramiento más compleja.

En el caso de las epístolas, por su alta condensación de subjetividad, por la presencia forzosa del yo, permiten, por un lado, contemplar la construcción identitaria del sujeto que escribe y se define en ese proyecto de creación; y por otro, indagar en la construcción de otredades, puesto que la carta se conforma como un elemento textual en el cual se refractan posibles identificaciones. Además, en los capítulos anteriores hemos visto el valor de la carta como documento privado e íntimo, pero al mismo tiempo, como texto de comunicación que adquiere visibilidad en espacios compartidos públicos o semi-públicos. En el desarrollo de los subtítulos que a continuación se presentan, también se recuperarán algunas ideas vinculadas con esta problemática.

\subsubsection{El autor maestro: el espacio letrado cómo ámbito discipular}

La primera hipótesis de lectura que se propone es la de leer la carta que le escribe José Jacinto Milanés a Domingo del Monte (1836) como un modelo de relación disciplinar, basado en la jerarquización, en el cual la construcción de subjetividades se repliega en el binomio maestro-discípulo. El posicionamiento del destinatario en el lugar del maestro conlleva una serie de actos enmascarados que revelan un doble proceso. Por un lado, un proceso de construcción del yo especular; por otro, un esbozo o configuración primaria del espacio de discusiones entre letrados en Cuba en las primeras décadas del siglo diecinueve.

Según nos permite constatar la cuantiosa correspondencia entre ambos, podemos sostener que José Jacinto Milanés es uno de los jóvenes poetas cuya práctica 
letrada es guiada por Domingo del Monte, tal como vimos en el capítulo II cuando analizamos el proceso de corrección llevado a cabo en la tertulia delmontina.

En primer término, se advierte que el diálogo posible con el maestro posiciona al discípulo en un lugar privilegiado, puesto que ese contacto revela no sólo la disposición de aquél en tanto que atiende las solicitudes del discípulo, sino la validez de las inquietudes planteadas. En segundo término, el tono íntimo y cercano que envuelve el contacto conforma la relación maestro-discípulo como un tipo de relación especial de enseñanza en la que el discípulo se autopresenta como "elegido" por el maestro, con la intención de sucederlo en el tiempo.

En la carta, la relación jerárquica se matiza por el uso de expresiones que denotan un tono de confianza y amistad. De este modo, la carta se construye bajo la orientación de dos tonos contrapuestos: uno que rige en el plano de la afectividad, y otro, en el plano del intelecto. La frase dedicatoria que da inicio a la carta se pliega sobre el primer tono: "Mi querido amigo" pone el énfasis en la cordialidad y cercanía del contacto. En tanto que la retórica de la humildad empleada revela la distancia intelectual existente entre emisor y destinatario. Por ejemplo, al proponerle la lectura de tres composiciones que ha escrito, J. J Milanés le refiere a del Monte: “Quisiera que me dijese V. llanamente si le parecen cubanas y qué otras mejoras puede admitir nuestro proyecto, no ahorrando reflexión ninguna sobre la materia, pues todo será conducente a su mejor logro" (Centón 60).

En esta construcción del buen discípulo, Milanés despliega una serie de estrategias que se presentan condensadas en el primer párrafo de la carta. La línea inicial exhibe una disculpa y la necesidad de justificación pone en evidencia una falta de quien se presenta como alumno. Hay un silencio que debe excusarse y la estrategia empleada por Milanés ante la ausencia de escritura en tanto respuesta demorada a del Monte es aducir la necesidad de un "estudio detenido" del asunto que lo implica. La demora, que conduce a un silencio, a la ausencia de palabras, sólo puede justificarse cuando el discípulo alega tiempo necesario para estudiar más.

La segunda estrategia defensiva es la de convertir el tiempo silenciado en escritura borrosa. El tiempo que demoró en responder a del Monte es el que empleó para estudiar y para escribir. Pero es una escritura deficiente, que lo ubica en la 
posición de iniciado. Dice Milanés: "Ya he dado principio a una, pero anda a paso de tortuga, porque todo se me va en corregir y borrar, siempre descontento del todo (¡maldito tono clásico!)”(Centón 58).

La tercera estrategia es la de compensar la falta mediante la comunicación de una idea. El acto creativo surge, entonces, como un rasgo positivo del discípulo, pero atento al beneplácito que busca obtener del maestro, resuelve el origen de la idea en una sugerencia que le realiza el propio del Monte. Escribe Milanés: "Pero en descuento le comunicaré una idea que me sugirieron tanto sus advertencias de V. como la lectura del Romancero de Durán, y se reduce a esto ${ }^{99 "}$ (Centón 58). Al respecto, cabe señalar que la cita de la lectura que realiza J.J. Milanés pone en evidencia el interés (y las nuevas "ideas") que despierta el romancero tanto en Domingo del Monte como en sus colegas.

El mecanismo de las estrategias da como resultado tres posicionamientos positivos del yo, que conducen a la autoconstrucción del poeta como un sujeto que, en tanto aprendiz, se presenta aplicado, productivo y humilde. De este modo, el discípulo responde porque es estudioso y produce textos e ideas pero expresa dicha producción de modo tal que quede en evidencia que necesita la mirada correctiva y el incentivo ingenioso del maestro. En consecuencia, Milanés realiza una construcción positiva pero controlada de su propia imagen como poeta u hombre de letras, que se basa en el "espejamiento" que produce en su figura la imagen legitimadora de Domingo del Monte.

Construida la retórica de la carta como una exposición argumentativa, el segundo y muy extenso párrafo se presenta como la instancia de expositio, de la idea presentada como rasgo de originalidad. En esta secuencia, el destinatario es interpelado

\footnotetext{
${ }^{99}$ No es casual la referencia a Agustín Durán, español, (1793-1862) pues es el responsable de una de las primeras antologías modernas del romancero castellano. Una primera recopilación de piezas que realiza el estudioso lleva por título Colección de romances antiguos o Romanceros y data de 1821. Luego compiló el Romancero General de 1828-1832, posiblemente la obra general a la que hace alusión José Jacinto Milanés en la carta fechada en 1836. Es de observar que el estudio de Agustín Durán abre paso a las antologías modernas de romanceros, al proponer un criterio ordenador del corpus basado en los aspectos temáticos. Recién en la recopilación de 1849-1851, denominada Colección de romances castellanos anteriores al siglo XVIII, Durán incorpora criterios estilísticos y cronológicos para categorizar los romances.
} 
a partir de una sucesión de interrogantes en los cuales queda expresada la idea de literatura y de identidad nacional que sostiene Milanés. El recurso de las preguntas permite la inclusión del destinatario como un otro que avala las propuestas elevadas. Las seis preguntas se distribuyen en la textualidad a modo de munición que carga las armas sobre la tesis propuesta, la cual se despliega en los mismos interrogantes.

Así como los romances, canciones, etc. de que se compone la obra son la poesía española de ley, por ser el eco fiel de las costumbres y opiniones del siglo $17^{\circ}$, y anteriores, ¿no podremos en Cuba, popularizando la poesía hacerla un espejo de nuestros usos y de las mil quinientas preocupaciones arraigadas en ellas? ¿No podremos con el arma del ridículo perseguir estas preocupaciones y pulir y mejorar nuestra sociedad en cuanto quepa? ¿De qué sirven esos sonetos, esas odas, esas serias y largas composiciones que no las entiende el pueblo cubano y que maldita es la mella que le hacen? ¿No es mejor que cada composición que se publique en nuestros periódicos, sea en primer lugar breve para que no fastidie, admita un tono sencillo, el que los cubanos tenemos, pinte nuestras cosas para que nos agrade, y a vueltas de lo fácil del verso, del fresco y original colorido, descubra cierta idea moral que sea como el alma de toda ella? (Centón 58).

El fragmento citado corresponde al núcleo central de la tesitura de J.J Milanés. En ellos se explicita la idea de una literatura para el pueblo cubano al mismo tiempo que se enuncian las características que debe reunir, tales como la sencillez del tono y la brevedad. Además, se exponen ciertas funciones específicas: ser "espejo" de las costumbres del pueblo cubano y transmitir un mensaje moral.

En este segundo párrafo Milanés realiza, aparte, una sucinta pero sólida presentación de la sociedad cubana. Efectúa una crítica a partir de la cual busca legitimar la idea de literatura que él promueve. Una literatura para el pueblo cubano debe, ante todo, entender las necesidades de ese pueblo y conocer sus características, para poder "espejarlas" y de ese modo, generar un cambio. Dice Milanés:

¿No cree V. que ganará esta clase de poesía a más del agrado de nuestros compatriotas, por ser toda criolla, el de los estrangeros a quienes interese el estado fiel de nuestros usos y opiniones en la época presente? Y ¡qué campo se nos abre! vea V. (sin tocar el pelo de la ropa a los negros, porque es fruta aquí vedada) vea $\mathrm{V}$. en nuestra sociedad tan falta de luces, ntra juventud lechuguina 
y ociosa: nuestra ancianidad, caprichosa y cerrada, que no ve más de lo presente, que a cualquier innovación, chilla, medrosa ante el poder, sacrificándolo todo a su comodidad y sin dar un paso hacia la luz ni las mejoras. Vea V. nuestras mugeres, frívolas por excelencia, filarmónicas cuando mas, idiotas, mas de lo regular, peligrosamente sensibles y que no tienen alma y vida mas que para el baile, para la moda y para murmurar y para no hacer nada (Centón 58-59).

Esta concepción pedagógica de la literatura que opera en el discurso de Milanés se halla en concordancia con un discurso racionalizador que nutre todas las áreas y postula la posibilidad del cambio mediante la educación. En este sentido, el proceso reformista, al cual hicimos referencia en el capítulo I, implicó la puesta en marcha de una serie de operaciones en el orden discursivo que se traducirían en expresiones tendientes a justificar la ruptura con la metrópoli española y a exponer, al mismo tiempo, los rasgos americanos teniendo en cuenta la peculiaridad de cada región, en este caso, de Cuba. Como ya hemos señalado, se genera así el germen del discurso de la autonomía individual y social del hombre americano, basado en las posibilidades reales de conocimiento de las propias condiciones socio-históricas. Cabe señalar como otro factor determinante de la formación de esa conciencia de las propias condiciones geográficas, étnicas, sociales, políticas y económicas, necesario para afirmar una identidad diferente, los aportes devenidos de los viajes científicos realizados en suelo americano, como el que llevó adelante Alexander von Humboldt entre 1807 y 1834. Por ejemplo, en el artículo "Noticias sobre Brasil" que analizamos en el capítulo II, el autor (cuyo nombre se desconoce) recupera los aportes de Humboldt para graficar los cuadros estadísticos y la situación de la esclavitud en otras áreas antillanas. Estos relatos e investigaciones modifican la mirada de Europa sobre América y, a su vez, alimentan los discursos de las élites criollas que hacen suyo el lenguaje y el método científico (Pratt 1997).

De acuerdo con estos principios, en la carta, la sociedad se presenta como un campo "fértil" en el cual la literatura debe actuar. Jóvenes, ancianos, mujeres y extranjeros son los grupos sociales sobre quienes la literatura debe captar su atención. No así los negros, expuestos como "fruta vedada" (Centón 58). 
Es interesante reparar en las características negativas atribuidas a los grupos mencionados. En esa caracterización se legitima aún más la figura del poeta que advierte los problemas de la sociedad y a su vez, posee un "arma", la literatura, para desde adentro, contribuir a la reflexión y a la formación. El panorama presenta un futuro incierto, al estar depositado en una juventud liviana y débil. La ancianidad también "frena" el progreso y el adelanto. La negación para dar "el paso hacia la luz" es una de las características de la vieja generación. A lo largo del texto, se recurre en tres ocasiones a la metáfora de la "entrada en las luces" para dar cuenta de la necesidad de modernización e innovación. Esta modernización es la que propone Milanés a del Monte a partir de pensar en una literatura "cubana y criolla".

El tercer y el cuarto párrafo de la carta constituyen el relato respecto de lo que le aconteció a Milanés cuando quiso llevar adelante su propuesta literaria a un periódico local. La inclusión textual de lo sucedido le sirve en su construcción retórica como prueba: la presentación de un caso como ejemplo del pensamiento retrógrado de imprenteros y editores. La referencia concreta se propone asimismo como caso ejemplar a partir del cual se puede generalizar la experiencia editorial de la época.

De esta anécdota que menciona Milanés es posible desprender dos lecturas con respecto al tema que nos ocupa. La primera lectura del caso se relaciona con la incipiente configuración de un ámbito literario en Cuba cuya existencia se traduce en cierta tensión entre el mundo literario (asociado al entretenimiento y la invención) y el mundo periodístico (ligado a la experiencia de los sucesos), tensión trasladada a sus agentes. El editor le anticipa a Milanés que su "composición” sólo deberá ocupar una columna del espacio en blanco, pues más haría que el periódico se "desacredite". En esta advertencia, se aprecia una noción de escritura en tanto materialidad que se concreta sobre el espacio en blanco. Leída desde esta clave, la escritura literaria se enfrenta por el espacio con otro tipo de escrituras. En el plano de la conformación de un ámbito letrado, lo que entra en lucha son las posiciones del poeta y del editor. Referirle la anécdota a del Monte es conveniente para Milanés porque ejemplifica la "falta de luces" a la que hace alusión en el segundo párrafo de la carta. De este modo, la exposición del caso otorga contundencia a las palabras de Milanés. 
Para comprender la pugna entre poeta y editores es preciso advertir que en el desarrollo de la actividad del periodismo en Cuba la figura del imprentero es fundamental. Tal como lo explica González Ripoll (2000), los periodistas de entonces eran unos aficionados que desde sus hogares se dedicaban a la tarea de escribir y divulgar opiniones con la intención de contribuir a la formación de la sociedad. En este sentido, la imprenta se constituyó en el "rostro físico" de la publicación. Muchas veces el impresor era también el editor de las publicaciones, en él se depositaba la responsabilidad respecto de lo publicable. Reconocimiento, censura y aprobación eran las tareas centrales del impresor/editor, razón por la cual, era considerado el "mayor conocedor de los entresijos financieros, artesanales y argumentales del papel" (González Ripoll 2000: 342).

La segunda lectura se relaciona con el modo en que Milanés autoconstruye su imagen y es la decisión que toma debido a lo condenable que le parece el accionar del editor y del imprentero. Milanés decide continuar con su escritura y "engabetarla" hasta el día en que sus escritos sean de utilidad. Con esta premisa, se elabora la idea de una escritura ligada a un fin, es decir, una escritura instrumental. El fin es tan noble que al no poder encontrar un ámbito en el que sus escritos puedan circular, Milanés recurre a la drástica solución de guardar, esconder sus escritos. Sin embargo, en esta construcción de una escritura oculta, también se revela la importancia del contacto con Domingo del Monte. Prueba de ello es el último párrafo de la carta, en el cual Milanés le comunica a su destinatario que le hará llegar tres composiciones, con el fin de que las evalúe y dé "justo juicio" respecto de si son composiciones verdaderamente “cubanas". Es decir, el ocultamiento es sólo relativo, porque hay un espacio de circulación literaria que se establece en el contacto con del Monte y a su vez, con otros escritores ligados a él.

De este modo, las cartas entre Del Monte y J.J Milanés se constituyen no sólo en un espacio de confesión y de formación sino de circulación privilegiada de textos literarios, composiciones completas, fragmentos y "adelantos de obras" en los que se advierten los interrogantes de los autores y queda al descubierto el propio mecanismo de la escritura: correcciones que implican modificaciones en el cuerpo del texto. Desde 
esta perspectiva y como ya referimos, la carta se convierte en un género que encierra el cuerpo de otros textos sirviéndole de canal de comunicación.

En la carta dos imaginarios se interrelacionan: la imagen del poeta en tanto hombre de letras y la conformación de una "literatura criolla cubana". Algunas cuestiones referidas al segundo imaginario ya han sido esbozadas, pero presentamos dos posibles interpretaciones teniendo en cuenta la textualidad particular de la carta. Una es la idea de la "literatura como el tercero ausente", la otra, es la concepción de la literatura como protagonista textual en tanto "tema de escritura presente". Según Eduardo Grüner (1996), quien plantea que toda carta, en cuanto género, expresa un vínculo especular en el instante de búsqueda de una Terceridad, se podría hipotetizar que en el caso de la carta escrita por J.J Milanés, esa Terceridad aludida es la literatura. Desde esta perspectiva, toda carta es por definición "un juego de dos pero que implica tres". El juego desatado puede ser resumido en tres instancias. La primera, un emisor que en su acto de escritura "ofrece" la carta como un regalo, pero espera cierto gesto de reciprocidad. Quien escribe la carta se ex-pone, es decir, se "pone fuera de sí", porque una vez enviada la carta tiene un destino propio, inmanejable. La segunda, un destinatario que "debe" responder (aunque no sea con otra carta) para no dejar al que escribe "abandonado" y cubrir la falta, el hiato que se produce. La tercera, un Otro que es aludido en ausencia. El tercero es la "condición erótica", en tanto que construye un “diálogo deseante". Dice Grüner: "La triangulación es la figura retórica privilegiada del género epistolar. Es el lugar tercero el que empuja un permanente desplazamiento por el cual el deseo se permite fabricar la imagen de un objeto imposible de obtener en lo real" (183).

En la carta que nos ocupa, Milanés se dirige a Domingo del Monte y convierte a la literatura en el Otro ausente. La literatura aparece entonces como el tercero que articula la comunicación, escribir hace aparecer al Otro. Ese Otro se circunscribe, en gran medida, a una tipología: el romance. La inclinación por el romance por parte de Del Monte puede explicarse por aspectos constitutivos del género, tanto en el nivel de producción como en el nivel de recepción y difusión. Pero no sólo el romance sino la literatura es el tema principal de la carta. Es el referente que se construye y transforma en presencia a través de la escritura. Remitiéndonos a Noé Jitrik (2000), si se considera 
la escritura como una actividad, se deslinda que el escritor es el sujeto de la acción y la escritura es el objeto. Atendiendo al carácter individual y subjetivo que caracteriza la escritura, el escritor se posiciona en el lugar de "quien sabe" sobre "qué escribir". Este saber implica un saber de la experiencia (heredada, intuida), un saber del conocimiento (de la cultura, de la lengua, de los textos) y un saber de la posibilidad (retórica de los canales).

En este sentido, la literatura se constituye en materia de escritura, en un saber específico que domina quien escribe. En la construcción de la imagen del poeta u hombre de letras que Milanés realiza en la carta, la literatura, en tanto objeto de escritura se convierte en un saber que legitima la posición del escribiente. El escritor que escribe de literatura reúne los tres saberes implicados en el "saber escribir" que diferencia la actividad de la escritura de otras actividades y, a su vez, con ese acto remite a la función poética $\mathrm{y}$, de este modo, a la especificidad misma que define la práctica de la escritura literaria. Según Jitrik, el saber de qué escribir hace del escritor una especie de "creador" y, al mismo tiempo, quien dispone de la escritura ejerce un poder apropiatorio, que es exaltado al máximo en la escritura literaria.

En la carta, la escritura hace presente a la literatura en tanto referente. El objeto de escritura adquiere un grado de metalenguaje al transformarse en un objeto cuestionado. La reflexión en torno a la literatura se expresa en tono de crítica, de observación y reclama gestos urgentes de quienes intervienen en el proceso de producción y recepción literaria.

La propia escritura de Milanés presente en la carta también puede ser considerada un espejamiento del proceso de formación que define el ámbito letrado cubano en las primeras décadas del siglo diecinueve. Es decir, hay una escritura "trazada" que en su materialidad sufre la auto-censura: "Y iqué campo se nos abre! Vea V. (sin tocar el pelo de la ropa a los negros, porque es fruta aquí vedada)" (Centón 58). Y también la censura externa:

Romero quería que mi composición no ocupase más de una columna en su papel, el cual se le desacreditaba con mucha poesía (Centón 59). 
$\mathrm{Y}$ es hombre de tan duras entendederas, que primero me dice que quiere amenizar su periódico con versos y luego me da a entender que éstos lo desacreditan (Centón 59).

La subjetividad se remarca en el texto con la intención de configurar un yo letrado fuerte, que hace de la escritura y la literatura un problema, ambas construidas como objeto y referente. El destinatario de la carta es un otro que legitima al emisor, quien a partir de una estrategia de configuración especular logra resaltar sus cualidades de "sujeto que escribe".

Por otro lado, en los fragmentos seleccionados de la carta advertimos la condensación de varios problemas en torno de la literatura: primero, qué valor tiene ésta en la sociedad. Está claro que para José Jacinto Milanés y para Domingo del Monte es un valor formativo, educador, moralizador. En tanto para el imprentero, la literatura solo sirve para amenizar, pero al mismo tiempo puede "desacreditar" a su periódico.

Respecto del género y del estilo, las afirmaciones de Milanés resultan un buen ejemplo de la tensión entre Neoclasicismo y Romanticismo ${ }^{100}$ al que aludíamos con anterioridad. En uno de los párrafos transcriptos Milanés pedía que se "popularice la poesía”, pues de qué sirven esas odas, esas elegías, esas largas composiciones que el pueblo no entiende. Cuando sentencia “¡maldito tono clásico!” también rechaza el Neoclasicismo y, por extensión, la solemnidad de sus géneros. Al pedir una literatura para el pueblo que "espeje las costumbres”, Milanés piensa en el "tono sencillo", en las canciones y en los romances españoles del siglo diecisiete, pues ve allí un modelo posible para transmitir lo cubano y lo criollo, ya que así como en España los romances sirvieron para difundir las costumbres del pueblo, lo mismo puede lograrse en Cuba.

En esa búsqueda de lo criollo quedará fuera, "vedado", "lo negro", considerado un elemento exógeno (ex-patriado), que no constituye la identidad cubana ${ }^{101}$. Este afán

\footnotetext{
${ }^{100}$ La influencia del Romanticismo también puede apreciarse en el trabajo de traducción que realizan los escritores cubanos. En el caso de José Jacinto Milanés, sus traducciones son muchas, pero nos parece interesante destacar la traducción que realiza de la obra de Víctor Hugo "Como ondas silenciosas" en la revista El Prisma en 1846. Citado en Arencibia Rodríguez 2004: 72.

101 Como ejemplo de esta condición de expatriados que comparte Del Monte con algunos poetas y escritores, transcribimos el siguiente fragmento de una carta enviada por J. Padrines a Domingo del Monte, fechada en 1836. Dice Padrines: "Milanés me ha comunicado el asunto que debe cantar a
} 
criollista desemboca en una corriente que los críticos como Cintio Vitier y Lezama Lima denominan "costumbrismo", "nativismo" o "criollismo", para aludir a la producción literaria de una serie de escritores como Francisco Pobeda (1796-1881), José Jacinto Milanés (1814-1863), Ramón Vélez Herrera (1808-1886), José Fornaris (1827-1889), Joaquín Lorenzo Luaces (1826-1867) y Miguel Teurbe Tolón (18201857), Gabriel de la Concepción Valdés "Plácido" (1809-184), Juan Cristóbal Nápoles Fajardo "El Cucalambé" (1829-1862) que junto a Domingo del Monte y al ya nombrado, Ramón de Palma, representan este movimiento ${ }^{102}$.

Como señala Vitier, “el nativismo y el costumbrismo están siempre a un paso del indigenismo" (1998: 121), por eso muchos escritores pertenecen a uno y a otro grupo (por ejemplo, Luaces, Vélez Herrera y Teurbe Tolón). Mientras que el Criollismo en el plano lírico opta por dos métricas, la décima y el romance para promover la diferenciación de lo español mediante la tipificación de lo criollo rural y realza al guajiro como emblema de la cultura cubana, el Indigenismo (más bien, el Indianismo, por su carácter de auto-exotismo) recupera la figura del indio siboney como sustrato cultural cubano. José Fornaris es quien, en 1855, con sus Cantos del Siboney hace del Indigenismo una "escuela". Según el crítico cubano, son tres los factores que favorecen la emergencia de este movimiento: primero, la "moda romántica" de exaltar al "hombre natural", al "bon sauvage"; segundo, el factor nacional, pues según Vitier, “está la necesidad de expresar bajo forma encubierta los ideales revolucionarios que para la segunda mitad del siglo tenían una fuerza avasalladora". Tercero, es el vínculo misterioso con la raza perdida que se intuye en la naturaleza insular. Dice José Fornaris:

invitación de usted. No hay duda que el cuadro es tétrico y horroroso, y los contrastes que usted le indica harán resaltar más y más la barbarie con que son tratados estos infelices africanos (...). El plan mío se reduce a pintar algunas costumbres de la raza etíope que le dan cierta fisonomía particular a la Isla de Cuba. (...) En seguida, bajo el epígrafe de "El Mayoral" pienso describir a este hombre singular de nuestros campos con sus lenguas patillas, su látigo y sus perros, gozándose en castigar a los míseros africanos, que hace temblar con una sola mirada, y haré por bosquejar igualmente su corrupción y su ignorancia, y su malicia, tan opuesta a la sencillez que parece debiera ser el honroso patrimonio de las gentes de campo" (Centón II 41).

${ }^{102}$ No solo en el plano de la lírica tuvo representantes esta corriente, en el campo de la narrativa, pueden citarse las obras de Anselmo Suárez y Romero como Ingenios (1840), Costumbres del Campo (1859) y la novela costumbrista de Cirilo Villaverde, El guajiro (1842), entre otras. 
Aunque mis cantos fueron un símbolo más que la historia de una raza, debo decir que no me era indiferente el destino que arrasó con los aborígenes. Bien sé yo que los cubanos descendemos por línea directa de los españoles, que su raza es la nuestra, que es suyo nuestro idioma, suya nuestra religión, suyas nuestras tradiciones, suyas nuestras virtudes, suyos nuestros vicios, que somos, según la expresión bíblica, sangre de su sangre y hueso de sus huesos...pero ¿cómo negar que por la naturaleza somos hermanos de los antiguos habitantes de Cuba? El mismo pedazo de terreno que los sustentó nos sustenta, el mismo sol que los alumbró, nos alumbra, y respiramos el mismo ambiente que respiraron ellos (1998: 124).

Esta cita también nos permite pensar el componente negro como un elemento externo, que no contribuye a lo cubano, sino que lo contamina, tal como lo analizamos en el capítulo I a propósito de las retóricas del mestizaje que se instalan en este período y que buscan dar respuesta al problema de la heterogeneidad racial, pero, sobre todo, al conflicto que genera la enorme masa de esclavos africanos cuyo porcentaje en continuo aumente generaba temor en la población criolla.

\subsubsection{Las máscaras del autor: ficcionalizaciones de la subjetividad}

El autor de la primera mitad del siglo diecinueve no es un sujeto que se dedica exclusivamente a la escritura. La escritura es una actividad que atraviesa otras funciones, por lo general, ligadas a la enseñanza, al desempeño en cargos diplomáticos o como funcionarios en distintas instituciones (Myers 2008; Mazín 2008). En esta primera etapa de desarrollo del ámbito letrado, el trabajo como corresponsales o colaboradores en diferentes publicaciones no es remunerado aunque sí otorga a quienes ejercen este rol un reconocimiento entre sus pares. La traducción, tal como vimos por extenso en el capítulo anterior, es otra de las actividades desarrolladas por los letrados. Hay escritores literarios y aquellos que se dedican a escribir sobre asuntos políticos, económicos, sociales. Pero esta multiplicidad de esferas (temática, textuales, laborales) es operada por unos pocos eruditos escribientes. Estos hombres de la pluma ejercen, además, tareas como editores, antologistas, críticos, por lo cual, el enmascaramiento aparece como la estrategia para irrumpir en distintas escenas y asumir distintos roles. 
En este sentido, los seudónimos y el anonimato son dos caras del mismo proceso, mediante el cual se busca borrar o difuminar al autor para integrarlo en una contingencia más amplia y universal, relacionada a un interés supra-individual, como puede ser, las expectativas de una clase.

Sin embargo, hay autores que elaboran una imagen de sí mismos basada en ciertos criterios, tales como "ser los precursores", "ser los más populares", "ser los más consultados", "ser los descubridores", etc. De alguna manera, estas personalidades acuñan poder simbólico y se convierten en referentes de cultura y de literatura. La imagen que proyectan coincide con la imagen que los otros le devuelven sobre sí mismos. Los otros, con su reconocimiento, aceptan y consienten una jerarquía en la cual el autor se ubica en un lugar central y superior, dejando para estos otros el lugar del discípulo.

La edificación de autoridad se produce, además, por una serie de marcas que reafirman el lugar asignado: el autor señala, corrige, advierte, sentencia. En estas cuatro acciones manifiesta la severidad y la asertividad de su discurso. En el lado opuesto, el autor discípulo: duda, pregunta, borronea, ensaya.

Las figuraciones de autor que trascienden son aquellas marcadas por la ejemplaridad, como es el caso de Domingo del Monte. Pues él se sitúa en lugar de ejemplo a seguir, de maestro. Pero, al mismo tiempo, asume múltiples funciones bajo desdoblamientos y enmascaramientos. Paradójicamente, esas operaciones ligadas a la edificación de la subjetividad no fragmentan la imagen del autor sino que, por el contrario, la potencian y la diseminan en diferentes ámbitos.

Del Monte publica en 1833 la antología poética Rimas americanas con una doble estrategia de enmascaramiento. Por un lado, recurre al seudónimo de "Bachiller Toribio Sánchez de Almodóvar" bajo el cual publica los cuatro romances cubanos que integran la obra, entre otros textos que no son de su autoría. Por otro lado, los biógrafos (Chacón y Calvo 1922; Fernández de Castro 1929) coinciden en señalar al propio Del Monte como el compilador de las obras líricas que integran la antología de las Rimas aunque figure como antologista un tal Ignacio Herrera Dávila.

Este enmascaramiento revela un complejo mecanismo de enunciación en el cual la voz portadora de autoridad, es decir, la del propio Del Monte, se desdobla en dos 
autores con la intención de legitimar, por un lado, un campo temático —el que refiere al mundo del guajiro y sus costumbres - y una práctica de escritura - el romance como género privilegiado para expresar la cubanidad ${ }^{103}$. Por otro, legitima su propia posición como autor, pues la inclusión de sus textos en la antología refuerza su condición de escritor americano y lo erige como portavoz del ideario de la patria cubana.

La relectura del "Prólogo" permite entender el tono sobre el cual se construye esta antología ${ }^{104}$. Desde el vocativo empleado "hispano-americanos" Del Monte tiende un lazo cultural que hermana en la lengua a España y América. Sin embargo, esa "hermandad" no es garantía de progreso, puesto que lo que este compilador observa con "extrañeza" (I) es "el no adelanto en la poesía".

Con la pregunta dirigida hacia los poetas “¿Por qué no volver la vista a este continente de América?", desde el "Prólogo" de las Rimas se busca problematizar la producción literaria e instalar como objeto poético el paisaje americano. La invocación recuerda el tono usado por Andrés Bello en su "Alocución a la poesía” en 1823 cuando insta a las musas a que abandonen la vieja Europa. En idéntico gesto, el prologuista convoca, entonces, a la recuperación de las imágenes americanas: "las gigantescas y tremendas cordilleras, los caudalosos ríos, el Niágara, los diamantes de Brasil, los metales de Méjico y Perú" (III).

Los poetas que integran la antología, en palabras del enmascarado Del Monte, "han abierto la verdadera senda de la poesía americana”, justamente, por dejar de lado la "imitación de las ideas" (IV). Frente a este panorama, la antología elaborada por Del Monte y publicada bajo el seudónimo de Herrera Dávila se constituye como la primera obra que recupera en Cuba la voz de los "verdaderos poetas americanos", es decir,

\footnotetext{
${ }^{103}$ Cabe mencionar que el juego de heterónimos es una constante en la literatura de los siglos diecinueve y principios del veinte, por ejemplo, en el ámbito luso hispano podemos reconocer a Joaquim Machado de Assis (1839-1908) y a Fernando Pessoa (1888-1935) como algunos de los escritores que emplearon este recurso.

${ }^{104}$ Me ha resultado muy iluminadora la lectura del artículo de Hernán Pas (2010) "La crítica editada. Juan María Gutierrez y la América poética" para pensar posibles relaciones con esta antología cubana, pues creo advertir en ella ese sesgo "moderno", "crítico", "evaluador" que Pas le reconoce a la Antología de Gutiérrez, y que constituyen parámetros modernos bajo los cuales se organiza una órbita literaria mediada por el juicio crítico.
} 
aquellos que eligen como inspiración y tema un repertorio local. En el "Prólogo" también se destacan dos autores canónicos, Cervantes y Homero, distinguidos ambos por "el tono con el cual cada uno pintó la fisonomía de su patria" (I).

El gesto que Del Monte asume con esta antología es construir un parnaso poético americano, en el cual el autor — criollo, blanco y varón- se construye como autoridad retórica y, al mismo tiempo, construye una categoría identitaria como "universal", que proyecta una "nación ideal" (Achugar 1996). En consecuencia, plasma en su poemario un orden legal y estético que se corresponde con su concepción de nación moderna, que excluye a quienes no cuajan con ese proyecto (negros y mulatos). En consecuencia, elabora una matriz identitaria que liga tres elementos: tierra-hombre-raza.

"El montero de la sabana", "El desterrado del Hato", "El guajiro" y "La Patria" son los títulos de los cuatro romances de Domingo del Monte que integran las Rimas. Si su intención es configurar un parnaso nacional, la lectura de los títulos permite identificar campos semánticos específicos mediante los cuales se elaboran las metáforas de pertenencia. La construcción de la idea de patria se elabora a partir de la identificación del sujeto con la tierra. Las voces que articulan esa identificación se desdoblan otorgando un carácter dramático a la estructura del romance. De este modo, los romances se construyen con una voz presentadora, que describe la escena, y una voz protagonista, que irrumpe con décimas, en un tono de canto, lamento o queja.

Pero los romances no solo exponen un imaginario cubano patriótico sino que muestran la concepción de literatura de Del Monte, que abarca dos entidades: lo americano y lo local y, en esa relación, se exponen la tensiones con la tradición y la modernidad. Como ya hemos señalado, el propio Domingo del Monte alienta entre sus coetáneos un proyecto de romancero cubano que plasme un imaginario patriótico que se corresponde con la emergencia de una conciencia criolla cubana. En el capítulo IV nos ocuparemos de analizar el imaginario patriótico del romancero cubano, pero antes consideramos necesario detenernos en la elección del romance como género. 


\subsection{El romance con la patria: el proyecto literario de Domingo del Monte}

Señalábamos que un grupo de los criollistas elige la décima como forma para vehiculizar el sentir patrio. No obstante, Del Monte insiste - "equivocadamente"- en el romance como género y encuentra en España un modelo "exitoso" de difusión de las costumbres a partir de esta forma literaria. Según Salvador Bueno,

A del Monte le preocupaba la búsqueda y formación de una tradición y una literatura propias. Por esto estimularía el tratamiento de asuntos americanos en la obra de sus contertulios y amigos, les presentaría las mejores fórmulas y los modelos más valiosos de la novela histórica y adoptaría —equivocadamenteel viejo romance español para ofrecer figuras y paisajes del campo cubano en su propio quehacer lírico. Ese americanismo literario que sería su preocupación constante de los mejores intelectuales de nuestros países latinoamericanos, tiene un adecuado teorizador en Domingo del Monte (1979: 37).

El reconocimiento a del Monte por "cubanizar" la poesía es contemporáneo a su proyecto. En páginas precedentes comentábamos que en 1854, Ramón de Palma (1812-1860), cuando publica los Cantares de Cuba, distingue a Domingo del Monte como el responsable del "primer acorde de poesía verdaderamente local que ha producido la lira cubana”. Y en el siglo veinte, el crítico Cintio Vitier en Lo cubano en la poesía lo ubica como "el principal propulsor de la orientación consciente y letrada de los Romances cubanos" (2002: 116). En tanto que Samuel Feijoo, el antologista más reconocido de los romances cubanos, en Los romances cubanos del siglo XIX afirma:

El misterioso Domingo del Monte fue el creador consciente de este movimiento. Veía el movimiento de los romances cubanos como un hecho estético provechoso, saludable, capaz de otorgar al país conciencia de sus costumbres, de su naturaleza distinta, de sus creaciones propias sin saber que con ello el país se daba rostro, cuerpo, ser, y que, ese rostro y ser, es peligro latente de los colonizadores (1977: 8).

Pese a este temprano reconocimiento, la vertiente criollista del romancero desarrollada por del Monte, aunque singularizada por la crítica (Poncet 1914; Feijoo 1977; Orta Ruiz 1980; Aguirre 1981; Trapero-Esquenazi 2002) carece del reconocimiento y 
estudio in extenso realizado sobre la décima (Ortiz 1950; Vitier 1957; Feijoo 1977; Orta Ruiz 1980; Carpentier 1987; Díaz Pimienta 1998; López Lemus 1999). En este sentido, si bien la historia es "testigo" de la pervivencia de la décima y el "fracaso" del romance — punto al que volveremos sobre el final de este capítulo- nos preguntamos qué aspectos intra-textuales y extra-textuales intervinieron en la elección que realiza Del Monte. En sus cuantiosos escritos no hallamos alguno en el que postule directamente la escritura de romances de tema cubano. No obstante, proponemos concebir el epistolario personal, los ensayos y los artículos de su autoría como un arte poética "desarmado" y rastrear en esas textualidades las reflexiones y las consideraciones sobre la literatura, con el objeto de ordenar y establecer algunas lógicas del pensamiento delmontino que nos permitan hipotetizar sobre la valoración del romance como género privilegiado para comportar valores patrióticos. Por esta razón, la respuesta que ensayamos no tiene un carácter absoluto, sino más bien, problemático, y se cimienta sobre algunas de las ideas centrales que atraviesan esta tesis y ordenan - según nuestro criterio - la esfera de la producción literaria decimonónica cubana. A saber: la tensión entre tradición y modernidad; el rol de los letrados en ese contexto de la modernidad signado por la heterogeneidad racial y marcado por vertiginosos cambios sociales, políticos y económicos que impactan directamente en el hombre; el valor asignado a la literatura dentro de la órbita de la Ilustración; las tensiones con el Romanticismo; la gestación y consolidación de una clase criolla que busca legitimación y brega por la autonomía cultural y política de la metrópoli.

En principio, la elección del romance como forma predilecta para expresar el sentimiento de patriotismo puede explicarse por las características constitutivas del género, las cuales ligan tradición a renovación y oralidad a escritura (Chicote 2012). Es por ello que se convierte en un género que despliega diversas posibilidades de apropiación por parte de los distintos agentes culturales. Teniendo presente el desarrollo del romancero tradicional tanto en la Península Ibérica como en América (Menéndez Pidal 1939; 1953; 1968; Díaz Roig 1990; Mariscal 1997; Catalán 1997) y la pervivencia del género y su continuo "reciclado", los críticos observan que es la capacidad narrativa y explicativa del romance y su estrecha vinculación con la esfera 
de la oralidad y de la escritura, lo que lo convierte en un género atemporal, apto para “atestiguar" la historia (Chicote 1998, 2012). El romance tiene en Cuba su propio desarrollo y evolución popular (Trapero-Esquenazi 2002) pero del Monte promueve el uso del género, vinculándolo al ámbito letrado, con el fin de exponer los aspectos y hábitos más característicos del cubano. En concordancia con la narrativa costumbrista que se desarrolla en el mismo período, estos romances cubanos intentan ser "cuadros", pintar la manera de ser y, de esa forma, configurar en el plano simbólico los aspectos que hacen a la ansiada identidad nacional.

En la carta que analizamos en el apartado 3.1 que integra este capítulo, José Jacinto Milanés establece una comparación entre la "poesía de ley" en España, "canciones y romances", que ha servido para retratar las costumbres del pueblo con la inminente necesidad de Cuba de gestar una identidad diferenciada de la metrópoli y la posibilidad de usar esos mismos géneros para espejar las costumbres cubanas. Dice Milanés “¿no podremos en Cuba, popularizando la poesía hacerla un espejo de nuestros usos y de las mil quinientas preocupaciones arraigadas en ellas?". El romance se propone como modelo, porque en España se ha empleado para tal fin; por otro lado, la popularidad del género permitiría una rápida penetración en la sociedad, cumpliendo de ese modo con el objetivo de transmitir ciertos valores morales y patrióticos. Además, Milanés expone dos condiciones que se deberían sumar a "lo popular del género", éstas son la brevedad y el tono sencillo. En este sentido y según la observación que realiza Milanés, el romance como género se ajusta a estos requisitos, pues su estructura lírica narrativa permite la presencia de un yo narrador que puede narrar la experiencia cubana en tanto expresión patriótica afectiva. A esto se suma una estructura métrica sostenida en versos octosílabos y la repetición de fórmulas que favorecen la memorización. Por otra parte, la ficcionalización de la oralidad cubana es posible dentro de la estructura del romance, pues éste se construye en muchos casos dialogalmente y es por ello que se registra tanto el uso de un léxico coloquial como ciertas marcas lingüísticas que exponen en la textualidad del género una confluencia singular de voces que podrían exponer el "tono sencillo" del cubano.

Si bien, en España, el romance como género tiene una impronta tradicional y oral que liga su producción a ámbitos populares y de carácter colectivo, con la 
imprenta, aparecen composiciones de carácter culto y letrado que conviven con las de signo oral y popular. El romancero transita una doble esfera con pares que entran en tensión: la oralidad y la escritura, por un lado, y la tradición y la modernidad, por otro. Se ofrece, en este sentido, como un género flexible que comporta en su configuración esta compleja transición y superposición. Diego Catalán, uno de los filólogos que ha estudiado con mayor rigurosidad la pervivencia del romancero tradicional, explica muy bien la distinción entre el romancero oral, antiguo, y el romancero escrito, "literario":

El romancero antiguo nos es básicamente conocido a través de la selección que de él realizaron los impresores de pliegos sueltos y cancioneros de bolsillo (dos de los más saneados negocios editoriales en la primera mitad del siglo XVI). Antes de la letra impresa y mientras duró el negocio, el romancero oral, para entonces género «pop», se cantaba en los más variados ambientes, tanto por los iletrados como por aquellos que, simultáneamente, participaban en el consumo de la otra literatura, la de la cultura "oficial". Después de 1551, el romancero oral y el romancero escrito correrán caminos en gran parte independientes. El romance, convertido en un "género" perfectamente admitido por la cultura oficial, tendrá en adelante una historia literaria. A la vez, los romances "viejos" y otros de más reciente creación seguirán viviendo como poesía oral; pero, poco a poco, esa poesía oral irá quedando excluida de los círculos literarios y en el curso del siglo XVII vendrá a ser ya considerada como exclusivo patrimonio de los incultos (1981: 38) ${ }^{105}$.

Además, el filólogo español sostiene que las diferencias entre el romancero literario y el tradicional también se plasmaron en la elección de los temas. Mientras que el romancero "literario" prefirió poner en primer plano los asuntos históricos y épicos nacionales, en detrimento de los novelescos y caballerescos, debido quizá a las preferencias ideológicas que editores y coleccionistas creyeron percibir o tendieron a impulsar en el público lector, la tradición oral promovió como tema central el novelesco, por su mayor capacidad de adaptación a los diferentes contextos culturales.

Del Monte era un gran conocedor de la literatura castellana, por lo tanto comprendía el valor histórico del romance y la posibilidad de pervivencia del género.

${ }^{105}$ Diego Catalán, conferencia ofrecida en 1981, titulada "El romance, hoy”. 
Este conocimiento, seguramente, lo condujo a la elección del romance como forma para vehiculizar todo un ideario patriótico, pues, por un lado, el género posibilitaba la memorización, la recitación y la difusión popular, el "boca en boca". Por otro, si las composiciones eran breves y de "tono sencillo", podían publicarse en los periódicos de la época (tal como ocurre con La Moda o Recreo Semanal del Bello Sexo).

El carácter oral que el género tiene permite la recreación colectiva y constante $\mathrm{y}$, de alguna manera, garantiza su pervivencia. Catalán considera que esta condición le permite al romancero reactualizarse permanentemente, pues concibe al romance de transmisión oral "como estructuras abiertas que buscan dinámicamente su perfección mediante el desarrollo de posibilidades contradictorias que ya están latentes en el estado anterior del texto" (1981: 37). Es muy probable que Del Monte también se haya inclinado por el romance a partir de reconocer este rasgo atemporal, pues un romance permitiría inculcar en el pueblo determinados valores que la cubanidad criolla ilustrada buscaba condensar y fijar. Por último, nos interesa pensar en la relación que el romance opera entre historia y mito. Según Catalán el mito sobrevive a la historia, pero no porque sea una estructura universal inamovible, por el contrario, por su capacidad de adaptación. "El mito se hace historia y habita entre nosotros" (1981: 39). Nos preguntamos si este valor de creador de mitos que detenta el romance no es también un motivo de elección del género, pues si el romance logra instalar una configuración simbólica determinada pero eliminar esa huella de creación, se torna un género privilegiado para edificar sistemas de valores.

Por otro lado, nos parece oportuno recuperar el artículo "Primeras poesías líricas de España" que Domingo del Monte publica en el primer número de la Revista Bimestre (mayo-junio de 1831) y cuyo análisis realizamos en el capítulo II. Si bien, en ese acápite enfocamos nuestra lectura en la revista como un nuevo espacio de difusión y socialización de temas ligados no solo a la literatura sino a los avances más variados, relacionados con la modernidad, consideramos traer a mención aspectos desarrollados en ese artículo y leerlos como claves de elección del género.

El primer aspecto a recuperar es la noción de una literatura lírica inspirada en lo nacional, que para Del Monte se desarrolla en España desde el "nacimiento del verso hasta el reinado de Carlos I". Este período se caracteriza por "la imaginación de todo 
un pueblo que se convierte en romances y canciones, cuando no conoce ni necesita modelos estraños, sino que infunde en todas sus producciones un verdadero espíritu nacional (10).

De esta concepción deviene la idea de una literatura que emerge del pueblo y que, por este motivo, expresa el espíritu nacional. Los romances y las canciones aparecen como formas validadas porque no existe la idea de un poeta individual, sino que el pueblo es poeta.

El conocimiento acabado de Domingo del Monte sobre la literatura castellana y el romance en particular queda en evidencia cuando expone los títulos y las apreciaciones respecto de algunas obras que abordan este primer período. El carácter crítico, es decir, la lectura especializada que Del Monte realiza sobre este corpus contribuye a generar la autofiguración del "autor/crítico", característica autoral que hemos analizado en segmentos anteriores. Señala Del Monte:

La colección del señor Grimm contiene en general romances, cuya materia pertenece a la fabulosa historia de Carlomagno y sus doce pares. La obra del señor Depping es una colección variada de romances narrativos, y la Floresta del señor Faber contiene una colección variada de romances y de composiciones líricas que bajo el título Canciones, Villancicos y Cancionetas llenan casi todos los cancioneros y romanceros de España (10).

La cita, además, nos permite observar ese rasgo de la modernidad que es la avidez de información que detentan las culturas periféricas, es decir, la curiosidad por lo que acontece en los centros de producción cultural. Este hecho también nos permite reparar en los procesos de lectura y de recepción de las producciones europeas, pues se evidencia una contemporaneidad entre las fechas de publicación de estos textos y las fechas de los artículos que reseña Domingo del Monte, por ejemplo, para la Revista Bimestre o la lista de las novedades en imprenta que figuran en el apartado "Novedades" presente en todos los números de la misma publicación (Goldgel 2010).

A continuación, el autor explicita el objetivo del artículo que es "dar a los lectores alguna idea de esta gran masa de poesía popular". La adjetivación "popular" se relaciona directamente con la noción de "literatura del pueblo" y debemos entender el pronombre posesivo como "creación" o "emanación” del pueblo. Es por ello que para 
Del Monte el valor de esta literatura castellana recae "en el espíritu nacional que le da armonía".

En el bosquejo que realiza, Del Monte parte de comparar la literatura con la evolución de los hombres y sostiene que hay poesía en estado de niñez que, por lo general, es la narrativa, la que precede a la poesía de contemplación. Esta poesía del primer período es una poesía narrativa (propia del romance) pero que tiene un "espíritu caballeresco y un acrisolado patriotismo" (14). En el contacto e influencia mutua entre poesía arábiga y castellana, señala Del Monte en el artículo que la poesía arábiga es muy elevada, pero la castellana ha influido aportando el "carácter nacional".

Por otro lado, en el artículo se desarrolla la idea de que la poesía evoluciona con los pueblos, de modo que un pueblo que todavía no ha alcanzado la madurez y la autonomía pero desea hacerlo, debería iniciar su literatura por una forma lírica que sea narrativa, pues la contemplativa es para estados de civilización más avanzados. En esta “encarnadura" nacional de la poesía española, en este patriotismo que detentan los romances del primer período, Del Monte encuentra un modelo a seguir, pues la etapa del romancero castellano expone el espíritu del pueblo y, como consecuencia, al considerar que Cuba está en una etapa anterior en el desarrollo de la civilización y de la cultura literaria, estima que el romance es el género poético narrativo que mejor se presta para expresar el sentimiento a la patria.

En la comparación que realiza entre la literatura arábiga (a la cual reconoce como una lírica “contemplativa”) y la literatura española, resalta que la lírica de ésta última es superior, pues,

en vez de aquel estilo difuso, de aquellas imágenes extravagantes, de aquella ponderación descabellada, que son al parecer inseparables de ánimos orientales solo aparecen en estas composiciones líricas una natural sencillez, una simplicidad sin afectación y un deseo de cortar toda la ramificación y redundancia para decir la idea sin ornamente alguno, sino tal como es y se presenta (16).

Debemos relacionar esta valoración respecto de los romances con las apreciaciones sobre el "tono sencillo" que Milanés proponía debía tener una poesía para el pueblo. En las sencillez, en la carencia del ornamento estaría la "esencia" de espíritu del 
pueblo. Ligado a este aspecto "despojado", la "falta de imaginación asombrosa" que detentan los romances castellanos se debe a que:

Es la poesía narrativa susceptible de muy poca variedad. Cuando se relatan sucesos, hay siempre algunas circunstancias fijas e inmutables, algunas cosas que en todos los siglos y en todos los tiempos se referirán del mismo modo, algunas señales particulares, que ni las mudanzas de las costumbres ni la cultura del entendimiento afectan su prístina esencia (16)

Al mismo tiempo, es el caudal histórico el que aporta la materia, el contenido de esos romances: "Ningún país ha aventajado a España en el caudal de materiales que da origen a la poesía lírica de una nación. Es su historia fértil en acciones buenas y malas y abunda de grandes acontecimientos y notables catástrofe en todo lo que es capaz de agitar y conmover el corazón humano" (17). En este sentido, hay una operación racionalizadora de la historia (propia del sujeto de la modernidad) llevada a cabo por Del Monte y otros escritores cubanos interesados en ordenar y clasificar ese caudal histórico y presentar, en consecuencia, aquellos elementos que contribuyan a la edificación de una identidad patriótica criolla. Recordemos, al respecto, el interés de Del Monte, Saco y otros por recuperar la obra de los historiadores criollos del siglo diecisiete, como Arrate, tal lo analizamos en el capítulo I.

Para comprender la valoración de Del Monte respecto del romance, transcribimos el siguiente apartado del artículo, en el cual se condensa su concepción sobre el género. Estas apreciaciones ponen en evidencia el conocimiento profundo que tiene sobre este género y cómo sus valoraciones anticipan enfoques teóricos posteriores:

No solo sobresalen en número los romances españoles sino también en calidades intrínsecas. Al comparar la primera literaturas de España con nuestros romances o con la poesía originaria de cualquier país, de repente se viene a los ojos cuánto las composiciones de la Península aventajan a las otras en elegancia, elevación y espíritu. Comúnmente leemos por curiosidad más que por gusto los primeros ensayos literarios de una nación. Pintan una serie de costumbres que en sí ofenden y fastidian, al mismo tiempo que atraen el corazón, porque difieren tanto de las nuestras y porque se refieren con un lenguage tan raro, que solo nos conmueve por no haber sorprendido al relator. 
Este da por supuesto lo que nosotros no podemos creer posible, y nace nuestro placer de la comparación que hacemos, que de las calidades intrínsecas de las obras. Los romances castellanos no necesitan de la misma escusa, ni es menester que para realce de su mérito, aleguen la rudeza de los tiempos. Tienen en si impresas las señales de la elevación, de la delicadeza, de la elegancia y todos ellos no hablan sino de cortes y de campos, dulcificados ya por la caballería (18).

El valor de los romances castellanos de la "primera época" reside en que tienen "delicadeza, elevación y espíritu", tríada de cualidades "intrínsecas" que debe entenderse en comparación con la literatura arábiga del mismo período, cuyo influjo es permanente, y con las literaturas primigenias de otras naciones. Estas otras composiciones tienen un "lenguaje raro" y "pintan costumbres que difieren de las nuestras", es por ello que el romance capta el espíritu del pueblo español. Más adelante, Del Monte insiste respecto del valor de este género, en tanto presenta un lenguaje llano y mantiene un principio de verosimilitud, diferente del oriental, entendido como "aquello que es posible":

La mayor parte de las bellezas de aquellas composiciones líricas castellanas [los romances sobre Carlomagno] son puras, castizas y originales. Los nombres de Guarinos, Montesinos, Durandarte, Baldovinos, Galván, Galvanos, Conde Irlos, Beltrán y muchos otros son casi propios y particulares de España. Las escenas en que nos los colocan son de muy diferente especie, no se hallan en ellas encantamientos estravagantes, ni dioses sobrenaturales. Los incidentes que se relatan, si bien adolecen algo de ponderación, están dentro de los límites de lo posible, los personages no están fuera de lo natural, se traslucen en ellos los vicios y las virtudes propias de la imperfecta humanidad. Tienen, además, el estilo y el lenguaje un no sé qué de sencillo y llano, que capta y arrastra constantemente la atención del lector (19).

Por las características desarrolladas, el romance es para Del Monte el género más apropiado para edificar y transmitir un ideario patriótico; por eso, sostenemos que en su rol de letrado, tal lo analizamos en el capítulo I, Del Monte asumirá la “misión” de encauzar la identidad nacional que debe comenzar a construir Cuba en pos de una futura autonomía, alentando en los literatos que lo rodean la escritura de romances de tema cubano. En esta labor consciente, de "artífice de la patria" podemos hipotetizar 
que Del Monte realiza un "uso letrado" del romance, tal la expresión que emplea Josefina Ludmer (1988) cuando analiza la apropiación letrada del género gauchesco en la región del Río de La Plata. Si bien, señalamos que el romance transita las dos tradiciones, la de la oralidad y la escritura, Del Monte pretende crear un romancero cubano letrado que cumpla la misma función formadora de identidad que tuvo el romance popular en España. Para eso, busca reproducir esas características que dotaron de "espíritu nacional" a la poesía narrativa castellana: la sencillez de tono, el lenguaje llano, la carencia de extravagancias, las escenas y los sucesos creíbles. Con estos elementos promueve la escritura de romances que, como "cuadros de costumbres", contribuyan a crear una primera matriz simbólica de la cubanidad. El primer paso, será, entonces, la elaboración letrada de ese romancero; luego, su difusión, la que permitirá, justamente, difuminar las huellas letradas de la creación y, de ese modo, propiciar la asimilación de un determinado imaginario nacional en el pueblo. Por los rasgos del género, esta difusión podía abarcar dos circuitos con tradiciones y estrategias de circulación propias y distintas: por un lado, una circulación oral, de "boca en boca", mediante la recitación; y, por otro, una circulación atada a la escritura, tanto privada y pública, diseminada en la prensa y en la correspondencia. Por otro lado, aparece un tercer espacio - las tertulias - cuyo análisis desarrollamos en el capítulo II. Este espacio decimonónico expresa un ambiente ilustrado, signado por la novedad y el intercambio permanente de lecturas, en el cual confluye la comunicación oral y la escrita, lo privado y lo público.

El uso que realiza Domingo del Monte del género puede, además, ser pensado desde la perspectiva teórica de Roger Chartier, quien formula el concepto de “apropiación” para explicar su teoría respecto de la relación entre los géneros y las clases sociales. Chartier (1998) rebate los estudios clásicos respecto de la caracterización de las diferentes poblaciones de lectores, que parten de la concepción de la posesión del libro para determinar qué lecturas y qué géneros eran "populares". Para Chartier, no existen a priori géneros destinados a determinadas clases sociales. Lo que observa es cómo, desde la época del Renacimiento, los distintos grupos sociales se apropian de esos géneros. Es la manera de "apropiación” lo que diferencia a los grupos, es decir, "los usos y las lecturas de los mismos textos por diferentes lectores" (1998: 
417). Roger Chartier entiende la lectura como apropiación en un doble sentido: "por un lado, la apropiación designa la 'efectuación', la 'actualización' de las posibilidades semánticas de un texto; por otro lado, sitúa la interpretación del texto como la mediación a través de la cual el lector puede llevar a cabo la comprensión en sí y la construcción de la 'realidad'” (1998: 424).

Si la apropiación que explica Chartier pone el acento en la materialidad de los objetos escritos y en los gestos de los sujetos lectores para explicar cómo grupos populares accedieron a determinadas lecturas, podemos pensar un movimiento a “contrapelo", en el cual Del Monte, desde su rol de letrado, se apropia de un género y de su tradición popular para "llegar al pueblo". Es decir, un género cuya génesis es popular, colectiva, oral pasa a la órbita de lo letrado para configurar un imaginario patriótico y volver a la esfera de lo popular, con el objeto de "formar" la identidad de ese pueblo.

Este rasgo puede ser explicado también desde la perspectiva de Johannes Kabatek (2005) como una "transformación" de la "tradición selectiva", pues las tradiciones selectivas se conforman de elementos que son arbitrarios (no necesarios) y se pueden transformar. En la elección que Domingo del Monte hace de la tradición discursiva que tiene el romance, opera un cambio que tiene que ver con su uso y su circulación. Kabatek entiende que:

Una tradición discursiva se establece a base de dos (o más de dos, claro está) textos relacionables por su contenido, lengua o forma o a base de dos situaciones (o constelaciones de entornos) que evocan dos textos relacionables. Un texto históricamente situado se relaciona con la constelación de entornos bajo la cual ha sido producido. Esta constelación de entornos es, a su vez, significable y puede adquirir valor simbólico. La repetición (siempre parcial) de los entornos de la primera enunciación evoca la repetición del texto (2005:152).

Bajo esta perspectiva, la "repetición" con respecto a la tradición discursiva de los romances se advierte en que los romances cubanos producidos a partir del tercer decenio del siglo diecinueve, manifiestan un contenido narrativo, una "historia", a través de un "discurso" doblemente articulado: a) en la métrica; b) en lo dramático. Los rasgos más constantes son el ritmo octosilábico y la asonancia en versos pares. 
También se da una adecuación de la estructura sintáctica a los esquemas rítmicos impuestos por el verso. Estos romances letrados se consideran como segmentos discursivos cerrados al igual que los romances eruditos o letrados de la tradición castellana. Por otro lado, en estos romances también se utiliza un modo de representación esencialmente dramático, es por ello que interviene la noción de "intriga"/ "fábula", entendida como la cadena de sucesos narrados ${ }^{106}$. Esta intriga se desarrolla en forma de "secuencias" que son las unidades mínimas con respecto al nivel de organización del relato. Muestra del carácter dramático es la presencia de diálogos, series descriptivas, fórmulas de instauración de un escenario antes de iniciar la acción como la difusión de expresiones destinadas a cambiar el escenario mediante la visualización ritualizada de los personajes. También se repiten con respecto a la tradición discursiva que ostenta el género ciertos valores comunicativos, como el "espíritu nacional" 107.

La teoría de Kabatek nos permite pensar las relaciones que se entablan entre el romancero cubano y la tradición del género, no solo en España sino en todas las regiones en donde se manifiesta. Kabatek se interesa además por las relaciones que una tradición discursiva mantiene con otras tradiciones. Para ello formula el concepto de "constelación de entorno". En el caso del romancero cubano, una constelación de entorno la configura la décima. Bajo la mirada de la "constelación", podemos analizar las proximidades y tensiones entre estas tradiciones discursivas y reparar en el juego de luces y sombras que se proyectan una sobre la otra.

\footnotetext{
${ }^{106}$ En el romancero tradicional hay que señalar que la repetición de carácter formulístico no es una mera repetición porque conlleva un plus de significado lexicalizado que excede el significado literal.

${ }^{107}$ Por otro lado, hay que señalar que la operación de apropiación del romancero popular por parte de la elite letrada es una constante en el género desde el siglo XV hasta el XX, ya que en distintas etapas los poetas letrados acudieron al romancero para narra la historia. Esta utilización es formulada explícitamente por los intelectuales de la Guerra Civil Española. En el ámbito literario de rioplatense, podemos mencionar la presencia de un Romancero sobre las Invasiones inglesas 1806-1807 de Pantaleón Rivarola (1754-1821).
} 


\title{
3.4.1. Coda: El "fracaso" del romance o el éxito de la décima
}

\author{
Décima es caña y banano, \\ es palma, ceiba y anón. \\ Décima es tabaco y ron, \\ café de encendido grano. \\ Décima es techo de guano, \\ es clave, guitarra y tres. \\ Es taburete en dos pies \\ y es Cuba de cuerpo entero, \\ porque ella nació primero \\ y nuestro pueblo después. \\ Mirta Aguirre ${ }^{108}$
}

Sostener que, en Cuba, décima y romance constituyen "constelaciones de entorno", según el término que desarrolla Johannes Kabatek para expresar la proximidad entre tradiciones discursivas, posibilita pensar de qué manera esas tradiciones entran en relación. Al respecto, podemos considerar, en primer lugar, dos aspectos que permiten establecer una comparación: el origen y la difusión.

La coexistencia se remonta a los tiempos de la conquista. El primer registro escrito que existe del romance se fecha en 1519, cuando Bernal Díaz del Castillo elabora con versos de romances el diálogo entre Hernán Cortés y Alonso Hernández Puertocarrero. Según Aurelio González Pérez (2000), el texto de Bernal pondría en evidencia el modo en que el romance estaba arraigado en las formas de expresión coloquial de los hombres que llegaron a América y, al mismo tiempo, de qué manera este género podía resultar verosímil para los receptores de la época ${ }^{109}$. También la décima, sostiene Virgilio López Lemus, llegó con los colonizadores de mayor cultura. En cuanto a su difusión, sostiene:

\footnotetext{
${ }^{108}$ Mirta Aguirre (1974) Juegos y otros poemas citado en López Lemus 1999: 24.

${ }^{109}$ Ver los trabajos sobre el romancero en Cuba de Aurelio González Pérez (2000) "El romancero en América y la tradición cubana" y también el trabajo de Beatriz Mariscal (1997) Romancero General de Cuba. México.
} 
Llegó de forma oral, o escrita, por medio del teatro, Si va a rastrearse el origen exacto de su asentamiento americano, habrá que aclarar cuáles fueron las primeras representaciones teatrales ofrecidas en el Nuevo Mundo. El teatro pudo ser una de las fuentes directas de su difusión entre los siglos XVII y XVIII, a partir de los centros urbanos, pero el amplio uso que le dieron los sectores aislados de la población, en los asentamientos campesinos, inclina a buscar también otros medios de difusión (López Lemus 1999: 25).

En este sentido, la hipótesis más consensuada respecto del origen de la tradición de la décima vincula esta forma con el culto religioso, pues la influencia catequizadora de la religión católica empleó esta estrofa como canto de iglesia y propició un movimiento de la décima desde los centros urbanos hacia los rurales, a través de las parroquias y de las fiestas religiosas (Orta Ruiz 1980). En las iglesias, la décima se empleaba en representaciones teatrales (autosacramentales) y en diversas actividades musicales. Los campesinos que vivían distantes convertían sus casas en rústicos templos los días de los santos y cantaban las décimas de la iglesia. De este modo, la décima se propaga oralmente de la iglesia, al bohío y a las calles. Alrededor de 1790 ya se podía detectar "una verdadera y legítima tradición oral de la décima", sobre todo cantada, tanto en los campos de Cuba (canturria) como en las ciudades (recitación o impresión de hojas sueltas). En este mismo momento, se advierten dos vertientes de la décima: la décima compuesta para ser cantada, o improvisándose mientras se canta preferentemente acompañada por instrumentos cordófonos; y la décima semi-improvisada, útil para el recitado o base para la memorización de los intérpretes. En este caso, puede ser resultado de la invención oral, mediando luego o no la escritura, y es habitual que tenga carácter más narrativo.

Otras tesituras sostienen un origen laico, teatral o por medio de glosas, pues éstas eran muy populares en España durante el siglo diecisiete y se cultivaban para todos los temas, profanos o sagrados.

Lo cierto es que en el siglo dieciocho, la décima ya registra un desarrollo autónomo en Cuba, esto quiere decir —en términos de Kabatek — que manifiesta una tradición en la que si bien se advierten "repeticiones", hay elementos nuevos, "transformadores". En este sentido, el éxito en la popularización de la décima parece estar ligado al momento en que se convierte en letra del cancionero popular. 
Esta característica, sostiene López Lemus,

la comparte con el romance, los villancicos, las coplas y con otras estrofas secularizadas. Hemos insistido en que la raíz misma de su amplia difusión como estrofa predilecta en nuestras tierras se debe en buena medida a la musicalización de la que fue objeto, hasta ocupar un importantísimo lugar en la cultura popular tradicional campesina (1999: 32).

Este lugar central, adquirido en un proceso de aceptación generalizada de la décima por parte de los versificadores populares y de los poetas de renombre, permite que la décima "llegue al siglo XIX ya convertida en una tradición peculiar, propia del país, nunca desvinculable con igual fenómeno en casi toda el área iberoamericana, pero con una autoctonía cubana, capaz de expresar asuntos identitarios de una nación emergente" (1999: 44). En la relación con otras tradiciones, la décima se impone y desplaza a los otros moldes, como el romance, pues según López Lemus, "la décima cantada y su música se intercomplementaron, formaron un complejo cultural en el que intervienen hombres y mujeres (poetas, intérpretes y músicos) que improvisan o interpretan series de décimas (componente estrófico) mediante variados instrumentos musicales (cordófonos, xilofónicos y percusivos)" (45).

En síntesis, el proceso de conformación de una tradición de la décima en Cuba hunde sus raíces en el siglo diecisiete, se establece como tradición hacia la segunda mitad del dieciocho y se consolida en el siglo diecinueve. Aunque se señaló la temprana correspondencia entre la décima y el sector rural, se puede afirmar que también se desarrolló bajo diferentes temáticas en las ciudades.

Si bien son muchos los estudiosos que advierten el éxito de la décima sobre el romance (Poncet y Cárdenas 1914; Feijoo 1977; López Lemus 1997; 1999; Vitier 2002) y, en ese sentido, señalan el desacierto de Del Monte por querer cubanizar esta forma, como explicita López Lemus "no es posible dar una respuesta definitiva al porqué se adoptó la décima por sobre la tradición coplera y la del romance hispánico". No obstante, este autor alega las siguientes "conjeturas valiosas": "pesan en ese arraigo la musicalidad de la espinela, su carácter estrófico cerrado en sí mismo, capaz de un mensaje completo en solo diez versos, la fuerza mnemotécnica de su estructura de rimas, la capacidad para ser cantada" (1999: 57). 
Mientras que el romance impulsado por Del Monte no alcanza el nivel de popularidad de la décima, ésta pervive hasta la actualidad ${ }^{110}$. Siguiendo a López Lemus, la décima no ha perdido la vitalidad para cantar y para contar, "narra desdichas y felicidades, felicita o celebra, loa a Dios o versa sobre el hombre y su destino. No le son ajenos la tierra y el cosmos. Vive en el verso improvisado y en el refinado por la escritura. Viaja desde los campos hasta las cárceles, en festivales muy concurridos y en audiciones en remotos parajes (1999: 68) ${ }^{111}$.

Para pensar desde otro lugar la relación entre décima y romance (pues mientras la décima "gana" en América, el romance se impone en España) nos parece oportuno enriquecer la discusión a partir de la reflexión que realiza Gloria Chicote (2012), quien concibe el romance americano como un "género proteico", pues:

Se presenta tanto en la forma heredada de sus congéneres europeos como diversificado en múltiples géneros: se engarza en coplas, se disfraza en payadas o salpica versos de cielitos y vidalas. El romance continua su fluir tradicional en América en dos vertientes fundamentales, una hispánica, caracterizada por la transmisión de los temas y motivos derivados de la España medieval, y una propiamente americana, en la que las funciones del género romancístico se han traspasado a otros géneros narrativos de desarrollo vernáculo, cuyo desarrollo está relacionado con los avatares del continente (2012: CI y CII).

Aunque en el ámbito americano no se discuta la popularidad de la décima, una tesitura que se opone a su "originalidad" es la que postula Alejo Carpentier (1987), quien sostiene:

En todo el siglo XIX cubano, las imprentas populares inundaron los pueblos y villorrios con tomos y más tomos de décimas para ser cantadas con acompañamiento del tiple. Pero esos tomos no incluían un compás de música. ¿Por qué? La razón es simple: si bien el guajiro es aficionado a renovar las

\footnotetext{
${ }^{110}$ De hecho, José Martí ha pronunciado algunas valoraciones sobre la décima, en el "Prólogo" a Los poetas de la guerra (1893).

${ }^{111}$ La pervivencia de la décima llega al siglo veintiuno, adaptándose e incorporando medios de difusión más tecnológicos. Al respecto dice López Lemus: "hacia 1930 las décimas asaltaron los programas radiales, luego aparecieron programas televisivos decimistas, y se han grabados, casetes y en CD, pasa así al orbe de la computación...Se van asegurando nuevos espacios para reinar en el siglo XXI" (1999: $68)$.
} 
palabras de sus cantos aprendiendo letras ajenas o recurriendo a su propia inspiración, no pretende introducir la menor variante en sus tonadas. Las décimas ofrecidas tenían que ajustarse a un modelo conocido por todos. En toda la isla canta sus décimas sobre diez o doce patrones, muy semejantes unos a otros, cuyas fuentes primeras pueden hallarse en cualquier romancero tradicional de Extremadura (1987: 454).

Desde esta perspectiva, las tradiciones de la décima y el romance se funden en un mismo origen, dando por tierra las teorizaciones que presentan a la décima como una “estrofa insoslayablemente cubana”. Enfatiza con ironía Carpentier:

A veces, como ocurrió recientemente con "La Guantanamera", un cantador guajiro parece haber inventado una melodía nueva. Pero no nos dejemos sorprender. Se trata simplemente de la reaparición de un romance, cuyo canto se conservaba tierras adentro. $\mathrm{Y}$ en cuanto a la tan mentada "cubanidad integral" de la melodía guajira tampoco debemos hacernos demasiadas ilusiones. La melodía guajira de Cuba es idéntica a la del galerón venezolano. Lo único que suele traer alguna variedad, ocasionalmente a este folklore estático, es el virtuosismo de un punteador, pero esos momentos felices no crean una tradición (455).

En este sentido, Carpentier considera que las expresiones de identidad que se ciñen sobre lo guajiro en forma excluyente son un signo de reproducción e imitación. La originalidad de la identidad cubana (y de sus manifestaciones culturales) hay que rastrearla en las expresiones afrocubanas, cuya "materia sonora es inagotable". Recién en la segunda década del siglo veinte, "al calor de la abortada revolución de Veteranos y Patriotas (1923)", cuando se forma con algunos escritores y artistas envueltos en el movimiento, el grupo Minorista, Carpentier observa la recuperación de una auténtica tradición musical en Cuba, a partir de la mirada renovada que "hizo eje sobre el negro" (457).

La mirada de Carpentier también nos permite problematizar las constelaciones de entorno del romance, pues no solo habría que situar en éste a la décima, sino también aquellas tradiciones ligadas a la cultura afrocubana. Ya analizamos en los capítulos anteriores cómo la demanda de mano de obra que implicaba la industria azucarera generó un aumento inusitado del tráfico de esclavos $\mathrm{y}$, por ende, una conformación de la sociedad cubana muy heterogénea. Sin dudas, esta configuración 
social sostenida por el ingenio tuvo un impacto preponderante y singular en la cultura popular, que ha sido oportunamente omitido o "vedado" (recordemos las palabras de Jacinto Milanés en la carta que le escribe a Del Monte: "sin tocar el pelo de la ropa a los negros, porque es fruta aquí vedada") en pos de ciertas construcciones identitarias colectivas, alentadas por grupos políticos particulares, que privilegiaron y acentuaron el componente criollo y blanco como signo de cubanidad ${ }^{112}$.

Esta veladura no implica su inexistencia. Por eso, analizar en el romancero decimonónico el imaginario que se edifica sobre la patria cubana, es decir, rastrear las configuraciones simbólicas que constituyen la cubanidad, y establecer relaciones entre ese ideario y el grupo productor, nos permitirá develar, al mismo tiempo, lo ocultado, pues el silencio también es otra forma de nombrar y la omisión, un gesto que leído a contramano, revela una presencia.

En el siguiente - y último capítulo - nos centraremos en analizar en un corpus de romances las figuraciones sobre la patria que articulan los intereses políticos y culturales de un sector — criollo, ilustrado y reformista - que, hacia la primera mitad del siglo diecinueve, reclama legitimidad en el poder y brega por una autonomía paulatina de la isla, toda una "peripecia de la modernidad". Proponemos, entonces, haciéndonos eco de Mabel Moraña (1997) "penetrar en los espacios sagrados de la letra", "interrogar estas narrativas que materializan íconos y símbolos" y legitiman en sus prácticas y discursos a la "nación criolla" (66).

\footnotetext{
112 Para complejizar aún más este panorama de contactos y tensiones entre las tradiciones, traemos a colación la referencia de Virgilio López Lemus, quien afirma que no existe un "decimismo negro pero a finales del siglo XIX aparecen improvisadores 'de color' cuando la décima como estrofa adoptada desde la impuesta cultura dominante iba a servir al negro como letra para algunas de sus expresiones musicales" (1999: 87).
} 


\section{Capítulo IV}

\section{Figuraciones de la patria en el romancero del siglo diecinueve}

La ficción provee un prospectivo archivo, no solo de diferentes 'palabras' en pugna en un mundo-de-vida que debía ser centralizado bajo la ley de la lengua nacional, sino también de posiciones discursivas nuevas y modelos de contacto y jerarquización entre las mismas en el espacio aún virtual de la nación futura (1996: 26).

La cita de Julio Ramos que presentamos a modo de apertura para este capítulo final cumple varios propósitos. En primer lugar, nos sitúa ante el desafío que la crítica de la ficción genera en aquellos que asumimos esta singular posición de lectores. Pero, en el caso de la tesis, este desafío es aún mayor, pues - parafraseando a Ramos - ese "recorte" del archivo literario - el corpus - surge ineluctablemente de la lectura que realizamos. El archivo literario "particular" que construimos nos permite sostener las hipótesis enunciadas y, al mismo tiempo, posibilita el desvío, pues pueden aparecer en escena nuevas preguntas devenidas de las formas de abordaje que distintos autores concibieron para sus respectivos (y diferentes) corpus. Tal es el caso de Julio Ramos, quien repara en la constitución de la subjetividad y su relación con la novela abolicionista cubana del siglo diecinueve, explorando los límites que demarcan y —al demarcar hacen posible - la configuración de un campo emergente de identidad. Su corpus no es estrictamente literario, pero le sirve para indagar en una discursividad "porosa y maleable" los límites que escinden "lo blanco de lo negro, la lengua propia de la de otro, el adentro del afuera" y las zonas de hibridez, "menos visibles y administrables" (23). En este sentido, los trabajos críticos que citamos en este acápite operan como cajas de resonancia que repercuten en nuestro acercamiento al romancero cubano decimonónico. 
En segundo lugar, la cita nos convoca a pensar en la complejidad del objeto de estudio, pues el "archivo literario" debe ser abordado teniendo presente las coordenadas espacio-temporales que definieron su producción. Al respecto, son dos los puntos de tensión que señala Ramos y ambos tienen como eje lo discursivo: el primero, es una "pugna de palabras" que centra el debate sobre la lengua nacional; el segundo, alude a las "posiciones discursivas nuevas", aquello que carece aún de estatus pero, sin embargo, emerge y genera una distorsión en el campo en el cual irrumpe (literario, jurídico, lingüístico, filosófico, etc.). En el recorrido que hemos propuesto, podríamos considerar que la coyuntura sobre "la pugna de palabras" fue abordada en los capítulos II y III, mientras que el capítulo I podría ser leído como la instancia en la cual problematizamos el impacto de la Modernidad en Cuba, a partir de considerar una serie de tensiones que articulaban diferentes discursos sobre la identidad. Como hemos analizado en los capítulos precedentes, hacia 1830, la Ilustración criolla, en sus diferentes facciones políticas (reformistas, anexionistas, separatistas) promueve un lento pero incesante proceso de configuración de la identidad nacional. En consecuencia, la literatura proyecta un entramado de figuraciones que se articulan con los idearios de nación que formulan estos grupos letrados. Nos preguntamos, entonces, de qué manera el archivo literario que concebimos se vuelve "prospectivo". Como ensayo de respuesta, en las páginas siguientes proponemos analizar, en un corpus de romances producidos por Domingo del Monte y algunos de sus contemporáneos, como Francisco Pobeda y Armenteros, Ramón Vélez Herrera, José Jacinto Milanés, Miguel Teurbe Tolón, y José Fornaris cómo se configura el imaginario patriótico y, con ello, explorar qué representaciones se elaboran en este repertorio sobre los sujetos, el espacio, la cultura y la literatura. Nos interesa, por un lado, analizar las figuraciones y las tensiones en torno al imaginario desplegado y, por otro, poner de manifiesto las estrategias que permiten esa representación en correspondencia con las corrientes estéticas que las contienen.

Asimismo, como hemos planteado en el capítulo anterior, este corpus de romances comparte su órbita de producción con otras tradiciones literarias, como son la décima y el romancero tradicional. En este sentido, nos parece oportuno poner en relación este repertorio con las temáticas y características del romancero tradicional, a 
fin de establecer algunas continuidades y, a la vez, poder reconocer los rasgos más originales. Al respecto, proponemos iniciar este último capítulo con un apartado en el cual se establezcan algunas líneas de comparación tendientes a problematizar la relación entre ambos romanceros.

\subsection{El romancero cubano y el romancero tradicional}

Maximiano Trapero en la "Introducción" de El romancero tradicional y general de Cuba (2002) señala que:

En Cuba, a diferencia de España, un libro que lleve por título el nombre de Romancero, deberá especificar que se trata de un romancero tradicional o popular, pues en caso de no llevar ese adjetivo reductor podría entenderse $-\mathrm{y}$ se entendería, de hecho — que el libro en cuestión trata del género romance en su más amplio sentido, como forma métrica particular de la literatura en lengua española, e inclusive se entendería en el sentido más restrictivo del romance como el género erudito, artístico. De ahí, por ejemplo, que el en libro pionero de Carolina Poncet, El romance en Cuba, se trate de todo tipo de romances, de los populares, pero también de los romances eruditos que en el siglo diecinueve se convirtieron en un movimiento literario de gran importancia en las letras cubanas (21).

La advertencia inicial que realiza Trapero nos parece que pone en evidencia la complejidad que conlleva abordar el género romance. Los estudios sobre la pervivencia del romancero tradicional en América constatan cómo los romances tradicionales han sido conservados y reactualizados a partir de la oralidad y la recreación colectiva:

Un romance tradicional es, en esencia, poesía colectiva, que requiere para su pervivencia una sucesión de procesos, todos ellos necesarios: primero ha de ser asumido por una colectividad, después ha de conservarse, y en esa conservación, al transmitirse oralmente de generación en generación, se recrea. Conservación y recreación son, pues, los dos polos de atracción entre los que vive el romancero tradicional (Trapero 2002: 24).

Esa es la dinámica que Diego Catalán (1997) explica en su Arte poética del romancero oral, en el que define al romance como "una poesía multiforme que vive en variación continua y permanencia esencial" (2). Desde su perspectiva, los romances tradicionales deben ser estudiados teniendo en cuenta tres aspectos: la "versión", es decir, cada una 
de las recitaciones de un romance recogidas de la tradición oral; el "motivo", cada uno de los elementos variables de una versión a otra que se dan en una narración romancística y, la "variación", o sea, todo giro de expresión característico de una serie de versiones y desconocido de otras.

En el ámbito americano, los estudiosos sobre el romancero reconocen el trabajo panorámico que desarrolló Mercedes Díaz Roig quien en 1990 publica el Romancero tradicional de América. En esta obra se compila un corpus romancístico compuesto por 1700 textos completos y numerosas versiones fragmentadas. Más allá de las compilaciones que durante todo el siglo veinte se realizan respecto del romancero tradicional americano, hay que mencionar que un primer acercamiento sistematizado por países sobre la poesía americana es el que realiza Marcelino Menéndez Pelayo en su Historia de la poesía Hispano-americana (1911), en el volumen I, capítulo III, reconoce a Domingo del Monte como un poeta singular, que le canta la patria cubana a pesar de ser originario de Santo Domingo.

Sin embargo, para entender el desarrollo de los estudios sobre el romancero, son ineludibles las observaciones generales que realiza Ramón Menéndez Pidal en su precursor estudio Los romances de América, de 1939, y que han marcado el rumbo de las investigaciones llevadas a cabo a posteriori ${ }^{113}$. Algunas de sus conclusiones, revisadas y ampliadas por numerosos estudiosos (Díaz Roig 1990; Mariscal 1996; Trapero 2002; Chicote 2012) nos permiten elaborar algunas reflexiones sobre el

${ }^{113}$ La influencia de Ramón Menéndez Pidal, cuyos preceptos devenían de la filología positivista, fue decisiva para los estudiosos que en las primeras décadas del siglo veinte se abocaron a la recolección del romancero tradicional. En el caso de Cuba, son precursores los ya citados trabajos de Carolina Poncet y de Cárdenas (1914), José María Chacón y Calvo (1914), y Sofía Córdova de Fernández (1924) pues marcan el inicio de los estudios folklóricos. En este periodo también se enmarcan las importantes obras de Vicuña Cifuentes en Chile (1912) y Ciro Bayo en Argentina (1913). Pero recién a mediados del siglo veinte los eruditos comienzan a interesarse por el romancero americano, y con mayor énfasis a partir de 1970, cuando la Cátedra Seminario Menéndez Pidal pone de manifiesto la necesidad de una renovación de los abordajes relacionados con la tradición oral romancística. Entre los trabajos de compilación que se desarrollan en esta etapa se destacan: en Cuba, Concepción T. Alzola (1961) y Beatriz Mariscal (1996); en Perú, Emilia Romero (1952); en Nicaragua, Ernesto Sánchez Mejía (1946); en República Dominicana, Edna Garrido (1946); en Colombia, Gisela Beutler (1969) y Germán de Granda (1976); en Chile, Raquel Barros y Manuel Danneman (1970); en Costa Rica, Michele Cruz-Saenz (1986); en México, Vicente Mendoza (1939), Mercedes Díaz Roig y Aurelio González Pérez (1986); en Guatemala, Carlos Navarrete (1987); en Chiloé, Maximiano Trapero y Juan Bahamonde (1998), en Argentina, Gloria Chicote $(2002,2012)$. Consultar referencias en Orduna. ed. (1976); González Pérez (2000); Trapero y Esquenazi (2002) y Chicote (2012). 
romancero cubano decimonónico que constituye nuestro objeto de estudio. Bajo ese interés, reproducimos las siguientes:

a) La implementación del romancero en América no se debe al momento exclusivo de la conquista y primera población por los españoles, sino que debe entenderse como una continua e ininterrumpida comunicación en el sentido España - América. Ello explica el abundante repertorio de temas modernos que vive en la tradición oral de América.

b) Dados los vastos territorios por los que se extiende el romancero en el Nuevo Mundo, llama "poderosamente" la atención la relativa uniformidad de ciertos repertorios de romances encontrados en países muy distantes entre sí.

c) Es notoria la ausencia de temas épicos, mientras que los temas novelescos fueron los que mejor se arraigaron en suelo americano.

d) Como ocurre en todas las ramas del romancero panhispánico, también las versiones americanas se cargaron de dialectalismos, se impregnaron del ambiente y del hablar vernáculo y se acomodaron a las peculiaridades culturales de los pueblos y de las gentes que las tomaron por suyas.

e) En América aparecieron nuevos temas romancísticos, inspirados en acontecimientos locales, pero conformes al lenguaje y al estilo del romancero general.

Al respecto, Gloria Chicote señala que la capacidad de metamorfosis del romancero tradicional puede ser ejemplificada en la región austral del continente americano con otro género que crece en popularidad en el siglo diecinueve: el romance criollo, que puede ser definido como una composición de género narrativo, con forma 8abcbdefeghih... Conocidos bajo diferentes denominaciones como "corrido", "verso", "versada", "compuesto", "argumento", estos romances se clasifican por su temática en noticiosos, sagrados e imaginativos (2012: CIV y CV).

En Cuba también se advierte un fenómeno parecido, ya que en paralelo al romancero tradicional cuya presencia y evolución se reconoce desde el siglo dieciséis, se produce un romancero letrado, que expresa la voluntad de los escritores criollos por 
“cubanizar la poesía”. Al respecto, Carolina Poncet y de Cárdenas, la primera estudiosa de este movimiento indica:

Para hallar un ensayo de aplicación del romance como género en nuestra patria, es preciso llegar al segundo tercio del siglo XIX, esto es, a la época en que el Romanticismo triunfa y en que el romance como forma de expresión se rehabilita en España bajo la influencia de la entonces nueva escuela. Cuba secundó este movimiento, tratando de adoptar el romance como forma de expresión de lo que se quería tomar como espíritu popular y de raza: esto es, para pintar la vida y las costumbres del guajiro, describir fingidas escenas de siboneyes; narrar algunos acontecimientos de nuestra entonces breve historia, o cuentos y leyendas más o menos verídicos sobre determinados tipos populares (1914: 33).

Es decir, los estudiosos del romancero cubano que han destinado algunas páginas al romancero letrado del diecinueve (Poncet y de Cárdenas 1914; Aguirre 1981; TraperoEsquenazi 2002) consideran que este repertorio no guarda relación con el romancero tradicional y que es "solo la aplicación del romance como género". Si bien esto es cierto, pues los temas romancísticos desarrollados en el romancero tradicional de Cuba no guardan relación intertextual con el romancero letrado decimonónico, aspecto que hemos constatado a partir de considerar el estudio de Maximiano Trapero y Marta Pérez Esquenazi (2002), quienes realizaron el relevamiento más actual del romancero tradicional en Cuba y ostentan una recolección de 745 versiones correspondientes a 53 temas romancísticos ${ }^{114}$, entendemos, no obstante, que es posible trazar algunas comparaciones entre los romanceros que pueden enriquecer el análisis que $\operatorname{proponemos}^{115}$.

114 Trapero y Esquenazi realizan una clasificación histórico-literaria y distinguen en cuatro grupos,
asimismo, realizan una clasificación - que sigue los criterios de Diego Catalán en su Catálogo general
del Romancero —dentro de estos grupos eminentemente temática, el resultado es el siguiente: 1 .
Romances tradicionales o tradicionalizados: a) de referencia histórica nacional, b)la conquista amorosa,
c) amor fiel, d) amor desgraciado, e)incesto, f) cautivos, g)vidas de santos e intervenciones milagrosas,
h) personajes y hechos históricos modernos i)noviazgos y matrimonios, j) solteras y viudas, k)
picarescos, l) animales. 2. Romances religiosos: a) nacimiento e infancia de Jesús, b) pasión y muerte de
Cristo, c) La virgen mediadora. 3. Romances vulgares popularizados y canciones narrativas: a) de
historia contemporánea, b) amores desgraciados, c) motivos varios. 4. Romances locales.
${ }^{115}$ Sobre la clasificación de los temas romancísticos se establecen diferentes criterios y, como bien
advierte Maximiano Trapero (2002) es un asunto no resuelto entre los estudiosos, a pesar de las muchas
tentativas al respecto y de las varias propuestas hechas por los especialistas. Por ejemplo, la clasificación 
En primer lugar, podemos establecer una relación con el romancero tradicional a partir de considerar el tipo de narración que presentan los romances: desde la perspectiva de la tercera persona narrativa; de la primera, o bien, la forma más usual que es el diálogo. En el romancero decimonónico aparecen las tres modalidades. En el caso de Domingo del Monte, sus romances se construyen en tercera persona y emplea la décima para que irrumpan otras voces en la composición. Francisco Poveda, Ramón Vélez Herrera y José Jacinto Milanés emplean el diálogo para otorgar mayor dramatismo a sus romances. En este sentido, la tradición del romancero ofrece a estos escritores fórmulas, giros y usos tales como: a) fórmulas de introducción al diálogo, b) fórmulas de diálogo, c) fórmulas de acción, d) frases adjetivas, e) frases adverbiales, f) epítetos.

Como señala Menéndez Pidal, los romances artificiosos se distinguen por su desborde lírico-retórico y las alusiones mitológicas y de la Antigüedad Clásica. Al respecto, en nuestro corpus podemos notar las influencias del Neoclasicismo y del Romanticismo, corrientes que aportan un imaginario retórico y simbólico particular.

Por otro lado, el modo de enfocar la historia también posibilita pensar algunas conexiones con el romancero tradicional. Menéndez Pidal $(1968 ; 1953)$ distingue tres tipos de romances: los romances-diálogos; los romances-cuentos y los romancesescena. Estos tipos no se encuentran individualmente sino que se combinan, aunque la diferencia entre los romances-cuento y los romances-escena es relevante: se distinguen porque en los primeros se desarrolla la historia al completo. A las anteriores clasificaciones, Mercedes Díaz Roig agrega otra estructura que denomina “concéntrica" en la que mediante unas repeticiones enumerativas se desarrolla el motivo central de la historia.

Al respecto de la clasificación anterior, podríamos considerar que mientras la mayoría de los romances castellanos pertenecen al tipo de romance-escena,

que establece Beatriz Mariscal en el Romancero de Cuba (1996) se centra en la lectura que la fábula de los romances tienen dentro de la estructura social, por ende, los clasifica en cinco grupos: 1) la mujer como objeto de acción, 2) la mujer como sujeto de acción, 3) el hombre como sujeto de acción, 4) romances de tema religioso, 5) los animales protagonistas. 
caracterizados por la fragmentación, con comienzo y final abrupto o trunco; en el caso de los romances letrados, estaríamos en presencia de la modalidad romance-cuento.

Por otro lado, en el romancero tradicional se destaca el uso de los tiempos verbales, pues la variación genera un ritmo narrativo, "zigzagueante", cuyo efecto se consigue con el paso rápido del presente a la evocación del pasado (pretérito perfecto, imperfecto y el pluscuamperfecto). Este juego temporal también se advierte en el romancero que elaboran los letrados criollos y produce el efecto de simultaneidad de la acción.

En cuanto a la temática, el romancero decimonónico considerado patriótico presenta diversos temas: algunos de índole más costumbrista, en los cuales el contenido fabulístico tiene que ver con los hábitos y las costumbres locales, como las festividades religiosas y las riñas de gallos; en este grupo se destacan los romances de Ramón Vélez Herrera y Miguel Teurbe Tolón. Los romances de Francisco Pobeda son de tema amoroso (enamoramiento, desengaño, traición) y ofrecen un imaginario centrado en el guajiro. Mientras que en el caso de José Jacinto Milanés el tema central es la esclavitud.

En síntesis, si bien el romancero que ocupa nuestro interés desarrolla otras temáticas, ciertas características que tienen que ver con la composición, el estilo y la estructura perviven y generan esa impresión de intemporalidad que distingue al romancero tradicional. Tal como referimos en el capítulo anterior, esta impronta del romancero es muy valorada por los letrados criollos que eligen este metro para proyectar y fraguar un ideario patriótico, y con este gesto, "arrastran" una tradición cuyas huellas se perciben. Al respecto, los apartados que a continuación se desarrollan tienen por objeto analizar el imaginario patriótico y establecer oportunas relaciones con la tradición del romancero.

\subsection{Las metáforas de la patria criolla}

Rafael Rojas en Motivos de Anteo (2008) precisa que un modo posible de estudiar una época de construcción nacional como la que se extiende en Cuba desde el siglo 
dieciocho hasta mediados del veinte ${ }^{116}$ sería la "hermenéutica de dos o tres nociones básicas", en torno a las cuales se articulan el repertorio simbólico y la formación discursiva de la comunidad naciente. Para Rojas, entidades como "la tierra, la sangre y la memoria - tan decisivas para la construcción del sujeto moderno- permiten remontar por una ladera, el devenir de las representaciones nacionales" (2008: 15).

Si bien en los capítulos precedentes hemos abordado las reflexiones teóricas de Rojas sobre los conceptos de "patria" y "nación", recuperamos en este tramo final de la tesis sus aportes, pues nos resultan muy funcionales para explicar cómo opera en el romancero la construcción de los conceptos de "patria" y "nación" y de sus variantes metafóricas: tierra, sangre y memoria. Éstas, advierte Rojas, tienen un desarrollo histórico, delimitado en el tiempo y el espacio, un "campo semántico descentrado y heterogéneo" (16). Es decir, estas metáforas se reactualizan y resignifican, por lo tanto, siempre deben revisarse en relación a un contexto de producción particular. En el caso del patriotismo criollo decimonónico, éste exaltaba el amor a la tierra natal y comenzaba a representar su comunidad bajo la forma de una ciudadanía con plenos derechos civiles y políticos. Todas las facciones que lo integraban (reformistas, autonomistas, anexionistas y separatistas) coincidían en que debía producirse un cambio en el estatuto colonial de la isla bajo el gobierno de España, pero divergían radicalmente en el tipo de soberanía que habría de adoptar el nuevo Estado. No obstante, más allá de las divisiones, se advierte en el patriotismo criollo la afirmación de una alteridad local dentro del territorio cultural hispánico, blanco y católico que consagra la patria como "paisaje" o "topofilia", el cual implica un sistema de apropiación y tenencia de la tierra, y al mismo tiempo, un trazado de límites de inclusión en la comunidad, frente a otros sujetos, como por ejemplo, la población negra.

Nos preguntamos qué rasgos ostenta esta topofilia criolla y cuáles son las metáforas que gravitan en este "paisaje" patriótico. En los apartados siguientes

\footnotetext{
116 Rafael Rojas considera que este espacio temporal - entre fines del siglo dieciocho, cuando se introduce el modelo de plantación azucarera en Cuba y el acceso a las primeras ideas e instituciones ilustradas generan entre la población blanca, negra y mestiza, un discurso de pertenencia y apropiación de la tierra hasta el siglo veinte, cuando se produce la modernización jurídica y política del orden republicano- se produce, "un largo proceso de transición de la alteridad criolla a la identidad propiamente nacional" (2008: 16).
} 
analizaremos el imaginario que la Ilustración criolla elabora y proyecta en el romancero cubano decimonónico.

\subsubsection{Naturaleza y paisaje: mediaciones de la mirada poética}

"Primero fue la peculiaridad de la naturaleza de la isla" sostiene Cintio Vitier en Lo cubano en la poesía (2002) cuando refiere que "lo cubano se revela, por la poesía, en grados cada vez más distintos y luminosos. No olvidemos [advierte el autor] que el fondo natural es decisivo para entender las configuraciones del carácter, el sentimiento y el espíritu" (29). Este principiar por la naturaleza se corresponde para Vitier con un proceso paulatino de interiorización del "modo de ser cubano". Ahora bien, ¿qué representaciones de la naturaleza se evocan desde el romancero que producen Domingo del Monte y otros escritores como Francisco Pobeda, Ramón Vélez Herrera, José Jacinto Milanés, José Fornaris y Miguel Teurbe Tolón?

En Rimas americanas (1833) aparecen publicados cuatro romances de Domingo del Monte: "El montero de la sabana", "El desterrado del hato", "El guagiro" y "La Patria". Estos romances condensan el imaginario delmontino pues articulan figuraciones sobre el espacio, los sujetos y su identidad que modulan el ideario de la patria criolla.

En "El montero de la sabana", romance constituido por 240 versos, el tema principal es el desaire amoroso que sufre un montero por parte de Felicia, quien decide casarse con un veguero rico, Albano. El romance narra el amor no correspondido del montero de la sabana y su venganza, cuando irrumpe en la boda de Felicia y Albano y mata al novio. Aunque el tema amoroso es universal, la referencia toponómica ancla el romance en un contexto plenamente cubano. En los versos que, a continuación citamos, se menciona al río Cuyaguateje, que baña la mayor parte de las vegas de Guane:

\footnotetext{
El manso Cuyaguateje

El de las ondas preciadas

Embravecido ya ruge

Y su linde, infiel traspasa

En tanto el firme montero
} 
El temporal mira, y anda,

Que no aterran temporales

Su enamorada constancia. $(25-32)^{117}$

Esta referencia regional es precisada por Domingo del Monte en una nota al pie registrada en la edición de las Rimas americanas de 1833. En este sentido, se destaca la aclaración que realiza, pues el romance integra una antología literaria americana, por lo tanto, se supone que otros lectores pueden desconocer el lugar mencionado. La topografía cumple con dos rasgos de la construcción letrada de la patria que realizan los criollos: por un lado, pone en evidencia la particularidad de la isla y, en correlato, la diferencia con otras regiones; por otro, manifiesta el conocimiento "natural" que el sujeto cubano tiene de su tierra.

La evocación de la naturaleza en tono romántico permite a la voz narradora expresar el dolor del montero del hato ante el desprecio de Felicia.

De este modo, para dar cuenta del paso del tiempo que marca la separación del montero y su enamorada, la voz narradora inscribe la metáfora de la palma:

Tres veces la palma hermosa

Honor de los campos nuestros

Renovó sus verdes yaguas

Y vistió de ramos nuevos,

Desde que el enamorado,

A su dama enterneciendo,

Alcanzó la primer cita

$\mathrm{Y}$ el inefable "te quiero". (97-104)

Cintio Vitier, en la "Segunda Lección" de Lo cubano en la poesía señala que "la palma es el símbolo ideal, erguido, anhelante, adecuado al despertar de la conciencia independentista" (2002: 63). Y agrega que el poeta que cifró este elemento de la

117 En el caso de este romance advertimos algunas fórmulas propias del romancero tradicional, tales como el uso de epítetos "manso Cuyaguateje"; la presencia de frases con verbos que marcan la acción: "mira y anda", las fórmulas de repetición con pocas variaciones: "el de las ondas preciadas / con sus puras ondas baña". 
naturaleza como símbolo de la isla fue José María Heredia (1803-1839) ${ }^{118}$. Al respecto, en la "Tercera Lección”, Vitier analiza la construcción de las parejas "palma-mujer” y “palma - patria” que Heredia elabora separadamente y que luego José Martí fundirá en su poética. En el caso de José María Heredia, contemporáneo y amigo de Domingo del Monte, la comparación de la palma con la mujer aparece en los versos del poema "A... en el baile" de $1821^{119}$. Por otro lado, cabe recordar que la relación entre Domingo del Monte y José María Heredia fue muy estrecha, hasta que se distanciaron cuando Heredia es desterrado y cree que Domingo del Monte se ha ligado al partido de sus perseguidores (Rojas 2007). De la etapa de intensa amistad y distanciamiento da cuenta Fina García Marruz en Estudios delmontinos (2008). La relación singular entre estos dos escritores, ha sido llevada a la ficción por el escritor cubano Leonardo Padura Fuentes en La novela de mi vida (2002) ${ }^{120}$.

No es casual, entonces, que Domingo del Monte replique en su romancero el valor de la palma cifrado por Heredia. En los versos de "El montero de la sabana" citados también se advierte la valoración sobre la naturaleza que realiza la voz narradora y, al mismo tiempo, la presencia de un posesivo que se identifica con lo cubano: "honor de nuestros campos". Esta valoración ficcional se repliega por fuera del romance en otras notas al pie en las cuales el autor aclara regionalismos, pero, al mismo tiempo, realiza singulares apreciaciones:

Así en el baile cantaba

Un veguero de Martínez ${ }^{1}$

De condición rica y vana. (132-134)

\footnotetext{
${ }^{118}$ El poema "La cifra" (1821) alude a la palma sin nombrarla, fue publicado en 1825, en Nueva York, en el compendio del autor titulado Poesías. Este poemario está disponible en versión digital en Googlebook. Las poesías completas se pueden consultar en Heredia, José María (1853) Poesías. Nueva y completa edición incluyendo varias poesías inéditas.

${ }^{119}$ La palma como elemento poético aparece en otros textos de la tradición literaria en Cuba, como el soneto de Ramón Zambrana Valdés (1817-1866) titulado, precisamente, "La palma" publicado en Cuatro laúdes por R. Zambrana, José G. Roldán, R.M. de Mendive, F.L de Briñas (1853).

${ }^{120}$ Un dato curioso sobre esta intensa amistad se revela en el artículo "Hallazgo de un regalo desconocido de Domingo del Monte a José María Heredia" (1939) en el cual Alfred Coester comenta el hallazgo por casualidad de una edición de las Rimas americanas que Del Monte le dedica a Heredia.
} 
En la nota al pie que consta en la publicación original Del Monte explicita: "San Juan y Martínez, asiento de las Vegas que producen el mejor tabaco del universo, está a cinco leguas de Pinar del Río y cuarenta y tres de la Habana” (1933: 9). En relación a esta valoración que opera en un nivel ficcional y en un nivel metacrítico, advertimos que en estos romances la naturaleza se convierte en paisaje doblemente contemplado: primero, por una voz narradora que incorpora otras voces, en general, a partir de décimas que cantan los guajiros y guajiras; y segundo, en la construcción del paisaje que realiza el autor y que se incorpora en el romance a partir de notas al pie. Este doble mecanismo refuerza la construcción de una naturaleza que deviene en paisaje de la patria. En este sentido, partimos de considerar la noción de paisaje como una mediación del hombre frente a la naturaleza. Es decir, el paisaje implica necesariamente la visión de sujeto, el ordenamiento espacial, la jerarquización de los elementos. En el caso de los romances, en esta conjugación paisajística, los epítetos funcionan de manera estructural pues se repiten cuando el objeto natural se reitera, tal el ejemplo que a continuación citamos: "El manso Cuyagauteje / con sus ondas preciadas"... "En cuanto el Cuyaguateje / con sus puras ondas baña".

Sin embargo, la naturaleza no es el reservorio exclusivo de lo patrio. En este romance, la patria también aparece ligada a las costumbres, a las labores del hombre en el campo:

\author{
Desnudo el patrio machete \\ Y despidiendo furores \\ A todos tira reveses \\ Cual cerdo furioso en monte. (209-212)
}

En el epíteto del primer verso se fragua el ideario criollo: la patria se resume en "el montero de la sabana" y, en un sentido metonímico, la herramienta de trabajo —el machete - comporta todo un imaginario cubano que vincula al hombre con el hato, la sabana, la vega.

El romance "El desterrado del hato" presenta las mismas connotaciones románticas sobre la naturaleza que "El montero de la sabana" y, al mismo tiempo, 
propone el paisaje cubano como fondo natural de un tema universal: el amor no correspondido $^{121}$.

\author{
Todo es silencio en el monte \\ En la mañana y hondón \\ Ni se oye res en la selva \\ $\mathrm{Ni}$ al tomeguín cantador \\ Tan callada está la tarde \\ Como triste el corazón. $(33-38)^{122}$
}

En este romance, un joven es echado por su padre, un "rico hatero de Albornoz", y en ese desarraigo llora la indiferencia de su amada. El destierro es un tema que se repite en los romances de Domingo del Monte y que nos permite pensar en el valor que los criollos asignan a la pertenencia a la tierra, pues esa salida forzada del terruño siempre causa dolor. En este caso, la toponimia también ancla el romance en el terruño cubano en nota al pie de la edición se aclara que "Consolación es una provincia de Pinar del Río:

Destierra al pobre mancebo

Del Sansueña alrededor

Desde la hacienda en que vive

Cercano a Consolación (9-12)

\footnotetext{
${ }^{121}$ El tema del destierro es recurrente en el romancero de Domingo del Monte. Al respecto, es ineludible la referencia al tópico del destierro que instala como tema nacional español el Poema de Mio Cid. Como señala Colin Smith (2005), el Poema (o Cantar) de mio Cid es el poema nacional de Castilla y uno de los grandes poemas de la Edad Media europea. Fue compuesto probablemente en los primeros años del siglo XIII en o cerca de Burdeos. Se trata de una mezcla de invención e historia que abarca casi dos decenios de la vida de Rodrigo Díaz de Vivar (1040-1099), conocido por los títulos honoríficos de El Cid y El Campeador. Si bien, han sido otros los episodios (y no precisamente el destierro) compuestos como romances en lo que se conoce como el "Ciclo del Cid" del romancero tradicional, consideramos que dada la impronta que esta obra tiene en la literatura castellana, es necesario, al menos realizar esta breve mención.

${ }^{122}$ La poética del silencio también connota una tradición literaria muy importante. Al respecto, puede consultarse el artículo de Aurora Egido (1986) "La poética del silencio en el Siglo de Oro. Su pervivencia".
} 
Cuando en el capítulo anterior abordábamos las complejas relaciones entre las tradiciones discursivas del romance y la décima, señalábamos puntos en contacto. En este sentido, muchos de los romances decimonónicos presentan en su composición décimas, pues se advierte que esta es la forma que mejor encauza la oralidad del guajiro. Una oralidad enmarcada o ficcionalizada en el interior del romance. Cada vez que un guajiro toma la palabra, se expresa con décimas cantadas, razón por la cual es posible sostener que el romance como género también contribuye a perpetuar la décima como forma popular. La incorporación de la décima redunda en una entonación particular del romance y también posibilita otras formas de memorización y circulación ligadas al canto ${ }^{123}$.

Citamos como ejemplo de este recurso el siguiente fragmento del romance "El desterrado del hato":

Por endulzar el presente

Requiere el tiple, y su voz,

Antes firmes, ora turbada,

Así a los vientos la dio:

-¿Qué se hizo aquel cantar

Que a mi señora cantaba

Cuando tierna me esperaba,

Bajo el fresco platanal?

¿Do se fue aquel mirar

Tan dulce que me robó

El alma toda, y a do

De mi padre las caricias

De mi hato las delicias...?

¡Ah, tiempo aquel! — ¡ya pasó!

Cantar solo aquesto pudo:

De su callar causas son,

Nos las faltas de la vena

${ }^{123}$ En este caso, para la presentación de otra voz, se recurre a las típicas fórmulas de presentación de diálogo empleadas en el romancero tradicional: "requiere el tiple, y su voz / así a los vientos la dio". 
Sino el recuerdo del amor

Que nunca la fácil Musa

Que en nuestras selvas nació,

Negar supo a este mancebo

Su sencilla inspiración. (45-66)

Por otro lado, nos interesa destacar los últimos versos, pues allí aparece una valoración respecto de la poesía que detenta lo autóctono: "fácil Musa que en nuestras selvas nació". Asimismo, la idea de "sencilla inspiración", se vincula con la poesía cantada que emerge de manera "natural" entre los guajiros.

En el romance "El guagiro" 124 no se desarrolla un núcleo de acción pues lo que más se destaca es la descripción del personaje que da título a esta composición de sesenta versos. Alfonso es un guajiro, oriundo de Alquízar (localidad que hasta el año 2010 perteneció al distrito de La Habana), y su enamorada, Belén, es una guajira de Guanajay. El romance opera como presentación de las virtudes de cada uno de estos personajes:

El apuesto guajiro,

Honor de su patria, Alquízar,

$\mathrm{Y}$ arrendador de los hatos

Del conde del Fernandina.

Gentil cuando rige el potro

Si danza a todos cautiva,

Y al revolver del machete

Nadie la palma le quita

A fuer de valiente y mozo

Sintió de amor las heridas (5-14)

Si el guajiro se distingue por su gallardía, por su valentía y por apariencia, la enamorada se diferencia de las demás por su belleza y su altanería. En cuanto a los rasgos fisonómicos, se destacan los ojos y el cabello negros y los labios rojos. También

\footnotetext{
${ }^{124}$ En el original de las Rimas americanas aparece escrito de esta manera "guagiro", pero en las referencias que realizamos sobre el texto en el transcurso de la tesis empleamos "guajiro".
} 
en esta caracterización podemos advertir cierta presencia del tópico romántico de la "mujer morena", en la cual se destacan los atributos corporales y sensuales, en oposición a una "mujer rubia", de carácter angelical y virginal.

Belén la de garbo y gracia,

La más donosa guajira

Que entre las hembras de Cuba

Con ojos negros hechizan:

Labios pequeños y rojos

Más que rojas clavelinas

Frente espaciosa, el cabello

Negro, luciente en sortijas (21-28)

Los celos movilizan al guajiro a ir en busca de su amada, pero este desplazamiento es sólo una excusa para presentar las características propias del personaje. Algunos versos más adelante, la voz narradora presenta, por ejemplo, el atuendo típico del guajiro:

Con un pañuelo pintado

De azules y rojas listas

De blanca y menuda paja

Por manos dulces tejidas

El sombrero toma, ornado

De dos borlas muy garridas (39-44)

Si bien en este romance no hay acciones que movilicen la narración, ni hay presencia de décimas en las cuales intervenga la voz del guajiro, el valor recae en la descripción pictórica de los personajes. El romance funciona como un cuadro de costumbres, como una pintura que permite fijar ciertos rasgos atribuidos a los guajiros. En este sentido, y en correspondencia con la intención formadora de Domingo del Monte, la caracterización de Alfonso y Belén debe ser entendida como "modelo", pues sus rasgos pueden aplicarse a otros guajiros y, al mismo tiempo, este proceso identificatorio diferenciador opera como límite de pertenencia para otros grupos. Es un límite racial 
— criollo y blanco - el que propone Domingo del Monte, por eso mismo podemos pensar en la metáfora de la sangre como religadora de la figuración positiva del guajiro.

Decíamos que estos cuatro romances pueden leerse como una poética o como un manifiesto patriótico-literario, pues en ellos se promueve una determinada idea de patria, criolla, blanca y cubana. Si en los dos primeros romances ("El montero de la sabana" y "El desterrado del hato") era evidente la construcción de una naturaleza como paisaje, es decir, la elaboración literaria de una naturaleza que se interioriza en los sujetos, y, en el tercer romance "El guajiro" aparece, precisamente, identificado el sujeto en el cual se depositan los rasgos de la patria; en el último romance titulado "La patria" (tal el orden con el que son presentados en la antología) se asimilan los elementos anteriores, pues en esta composición de 83 versos convergen la naturaleza como paisaje, el guajiro y la simbolización del sentimiento patrio a partir de la idea del destierro. En términos de Rafael Rojas, podríamos sostener que en el romance "La Patria" operan las tres metáforas que posibilitan explicar la construcción de la nacionalidad cubana. La tierra, la sangre y la memoria son entidades metafóricas que pueden leerse en lo profundo del poema.

El tema central de este romance es el lamento por la patria perdida (o dejada). Un destierro aparece como tópico para explicar el sentimiento patrio ${ }^{125}$. El romance se inicia con una décima, bajo la cual se presenta la voz quejosa del guajiro, en la que de inmediato se presenta la comparación con la tierra de Castilla. Por otro lado, la décima

\footnotetext{
${ }^{125}$ Como ya señalamos, el destierro es un tópico literario plausible de rastrearse desde la Antigüedad clásica, pero en la literatura castellana, es el destierro que sufre el Cid Campeador el que instala el desarraigo de la patria como el peor de los castigos. La idea del destierro está presente, además, en el contexto político en el cual Domingo del Monte produce su obra, pues muchos de sus contemporáneos y allegados son condenados al destierro, tales los casos de José Antonio Saco y el poeta José María Heredia. Este será quien instale en su poemario el tema del dolor por el destierro que sufre en 1823. En sus titulados "Poemas patrióticos", entre los cuales se destaca "El himno del desterrado" (1825) y "A Emilia", (1824) el tema central es la nostalgia generada por el destierro. De 1824 es también la célebre oda al "Niágara", en la cual aparece la palma como símbolo de la patria añorada. El tema del destierro vuelve a ser tratado poéticamente cuando a mediados del siglo, en 1858, un grupo de escritores exiliados reúne su obra poética en la antología El laúd del desterrado que se edita en Nueva York. Sobre finales del siglo diecinueve, José Martí también abordará la temática del destierro en su poemario Flores del destierro (1878-1895). En la literatura del siglo veinte, exilio y destierro operan como tópicos que fundan toda una línea de producción discursiva, por citar solo un ejemplo, traemos a mención el caso de Severo Sarduy y su emblemático ensayo Exiliado de sí mismo publicado en El País (España) en 1992.
} 
que inicia la composición es una invocación, recurso característico del romancero tradicional:

\author{
-iMal hayas tú, Manzanares, \\ El de las ondas mezquino \\ Mal haya el que a Mantua vino, \\ Dejando el patrio Almendares! \\ ¡Mal haya el que sus palmares \\ Y su floreciente orilla \\ Y su cielo donde brilla \\ Siempre azul y la rosa \\ Trocó por esta enojosa \\ Tierra helada de Castilla! (1-10)
}

Las figuraciones sobre lo nacional se elaboran en campos semánticos que refuerzan el contraste entre Cuba y Castilla: "brilla", "azul" y "rosa", como elementos que ponderan la calidez se oponen a "enojosa tierra helada". Si en los romances anteriores, el atributo de lo "patrio" adjetivaba elementos como el machete, en este caso, patria es la tierra misma, el suelo donde se ha nacido, "Almendares”. El destierro implica, por lo tanto, su abandono.

Por otro lado, la identidad patriótica se construye a partir de la contemplación del paisaje. Pero, en este romance se trata de un paisaje que no se corresponde con lo que los ojos quisieran ver:
Así mirando a la sierra
Del nevado Guadarrama,
Maldice de su fortuna
Un sitiero de Managua.
Por influjos de su estrella,
Que siempre la hubo contraria
En las dehesas se mira
De la más remota España.
Por la aterida ribera 
Los ojos del triste vagan

$\mathrm{Y}$ en vano busca por ella

Las flores de su sabana. (11-23)

En consecuencia, lo que emerge es la evocación del paisaje; el recuerdo opera como instancia que posibilita la permanencia en la tierra amada. La mirada también se desdobla, hay por un lado, una mirada errática, perdida, pues los ojos del sitiero triste "vagan y en vano buscan", pero al mismo tiempo, hay una mirada interna, que recupera el paisaje cubano y lo convierte en anhelo.

En vano descubrir quiere

Los árboles de su patria;

¡ay que sólo mira el triste

Marchita, incógnita planta! (24-27)

El último verso del fragmento transcripto permite ejemplificar la extrañeza que le provoca al sujeto desterrado esa naturaleza de España, a la que se suma el sentimiento de rechazo:

Yermo el prado, turbio el río

La natura desmayada, ¡cuán distinto cuadro ofrecen

Del de su nativa estancia!

Allí todo es verde pompa, Todas son silvestres galas, $\mathrm{Y}$ las auroras de enero

Con las de abril se igualan (32-39)

Este romance es importante en función del ideario patriótico de Domingo del Monte pues instala de forma explícita la diferencia con España. No solo la naturaleza es diferente, el clima cálido aparece como un elemento central de la matriz simbólica de 
Cuba. Si bien sobre finales del siglo diecinueve y principios del veinte, en concordancia con la mirada determinista-naturalista se desarrollan una serie de ensayos en los cuales el clima aparece como un factor que influye (negativamente) en las condiciones sociales que se gestan en el Caribe, es de notar que, en esta temprana configuración identitaria, el clima cálido se connota de manera positiva, y contribuye al imaginario de "isla paradisíaca".

La naturaleza como paisaje y el paisaje como evocación generan un doble desplazamiento simbólico, y podríamos decir que las metáforas de la tierra y de la memoria se superponen, pues es la metáfora de la memoria la que alimenta la de la tierra, ya que es la tierra en ausencia la que se vuelve memoria y la torna presente a través de la escritura. Al mismo tiempo, ambas metáforas sucumben en la de la sangre, $\mathrm{y}$, en consecuencia, el guajiro emerge como la figuración sobre la cual se repliegan estas dos entidades.

En todo el romance, la naturaleza es doblemente "extrañada", porque el sujeto que extraña y añora una naturaleza, la cubana, al mismo tiempo, extraña y desconoce la otra, la naturaleza española. La comparación se convierte en el recurso retórico que organiza la significación de la tierra en tanto paisaje rememorado:

¿Do el diáfano puro ambiente

Está mi Cuba amada?

¡Quién me diera un solo rayo

Del sol que sus campos baña!

Sus campos...¡AAh!, ¡quién los viera!

¡Cómo anhelante volara,

Rápida más que los aires,

A saludarlos el alma

Que el alma bien los conoce:

Ni son no, para olvidarlas

Las horas gratas que en ellos

De mi mocedad pasaba. (44-55) 
El tono nostálgico se construye además con versos exclamativos tales como “iQuién me diera un solo rayo / del sol que sus campos baña!”. Es de notar que la presencia de este recurso pone en evidencia el constante intertexto poético con el romancero tradicional.

En el fragmento citado, el verso "Que el alma bien los conoce" articula dos espacios que podrían oponerse: el del conocimiento con el del sentimiento. Pero la tensión se resuelve porque, en lo que refiere al conocimiento de la patria, es el sujeto nativo el que más sabe y, al mismo tiempo, el que más “siente” esa tierra. También en esta mención del alma que conoce podríamos advertir un tópico romántico, que vincula sujeto y tierra en una relación primigenia y originaria. En síntesis, se elabora un paisaje que se peculiariza y singulariza frente al español a partir del conocimiento sobre el propio espacio natural que tienen los cubanos.

\subsubsection{La tierra explotada: del paisaje del cañaveral al ingenio}

En el romance "La Patria", la tierra idealizada es el campo cubano, sin embargo, la referencia a la naturaleza no se agota en la evocación. En este sentido, en el romance opera otro desdoblamiento: pues a la naturaleza idealizada, que es objeto de contemplación, se opone una naturaleza explotada. El campo cubano no es solo el espacio donde el guajiro crece y disfruta de su ocio, es también el lugar de trabajo.

En consecuencia, el romancero se ofrece como un espacio simbólico en el que se conjugan las intenciones ideológicas de la elite criolla ilustrada. La naturaleza explotada es el cañaveral fagocitado por la poderosa industria del ingenio. El campo, en tanto imaginario condensador de representaciones transita un doble proceso de configuración. Por un lado, se constituye como espacio literario, como topos romántico. Pero al mismo tiempo, en ese topos se expresan las condiciones materiales históricas, razón por la cual, ese espacio se complejiza bien como "espacio que se apropia y tiene un valor mercantil", ligado al trabajo, o como "espacio puro y virgen", evocado desde una mirada ociosa. A su vez, la referencia a la apropiación exige otro desdoblamiento que conlleva también una carga valorativa. En los romances se distingue, entonces, la faena manual, esforzada del guajiro que trabaja la tierra, y el 
trabajo industrial del ingenio, donde se expone la explotación de la tierra, pero también de los cuerpos.

\author{
¡Que el viento sonando halaga... \\ Único son que se oyera \\ En ti, mi inocente estancia! \\ Que nunca escuchar yo pude \\ Sin que hirviese en ira le alma \\ El bárbaro atroz chasquido \\ Del látigo en carne esclava. \\ Sólo el sudor de mi frente \\ Libre, enhiesta, muy honrada, \\ De mis sembrados surcos \\ Regó con sus gotas santas... \\ Y más prefiero orgulloso \\ Pobre vivir más sin mancha, \\ Que no en opulencia infame \\ A infame precio comprada (65-79)
}

Las metáforas de la tierra se desdoblan en dos variantes: la "tierra trabajada" se opone a la "tierra explotada", la marca de distinción está en el uso de la tierra y en los intereses de los sujetos. Mientras que la primera metáfora condensa una carga positiva, como el lugar donde el guajiro reside, en convivencia armónica con la naturaleza; la segunda expone la crueldad del ingenio y la esclavitud como síntoma de barbarie.

En los romances donde la naturaleza romántica es paisaje ocioso que se recuerda o anhela, o tal vez "espacio amoroso" que circunscribe las historias de amor entre los guajiros, opera una retórica de la enumeración y de la descripción. Por el contrario, en los romances donde la naturaleza es espacio explotado, la construcción de los versos adquiere una dinámica que reposa en las acciones y se emplean estrategias como la repetición para dar cuenta de la condición de sometimiento de los hombres en el ingenio. Al respecto, es significativo que en el romance "La Patria", su autor, Domingo del Monte mencione la esclavitud, pues como hemos analizado en los capítulos precedentes, la postura que tenía respecto de la trata era muy compleja, 
oscilaba entre la justificación, "un mal necesario" y que "redime a una raza inferior", y el rechazo filantrópico propio de la Ilustración. En este romance, en la voz del guajiro se expresa la conmoción que causa en su alma la esclavitud: "que nunca escuchar yo pude/sin que me hirviese en ira el alma/ el bárbaro atroz chasquido/del látigo en carne esclava". La metonimia desplaza el significante "carne" por "cuerpo", y luego "cuerpo" por "esclavo", y en el juego que esta distancia genera, éste último, el esclavo, termina por convertirse solo en una evocación. Incluso, la referencia al sonido del látigo, al que opone el son, juega también en un plano del recuerdo. En la "inocente" estancia solo se escucha el ruido "natural" del viento. La metáfora de la memoria vuelve a intervenir para dotar de otro sentido al espacio natural en relación al trabajo del sujeto:

Solo el sudor de mi frente

Libre, enhiesta, muy honrada

De mis sembrados los surcos

Regó con sus gotas santas... (72-75)

De este modo, en correspondencia con la intención de configurar un imaginario patriótico, y en relación inmediata con un objetivo formador y edificante, en los romances se demarca un doble proceso de significación positiva. Por un lado, un tipo social como el referente máximo de cubanidad, "el guajiro". Así, el sujeto nacional imaginado por el discurso de los reformistas modernizadores, como Domingo del Monte, se articula en términos raciales, proponiendo al criollo blanco como emblema de cubanidad. Por otro lado, demarca un modelo económico que promueve el trabajo asalariado, sustentado por las bases del discurso abolicionista. Según la visión de los letrados reformistas, este doble proceso conllevaría a la solución del problema de la heterogeneidad racial en la isla.

La construcción del imaginario patriótico que analizamos en estos cuatro romances de Domingo del Monte se replica en los que producen otros escritores. Si en el caso de Del Monte podemos advertir que la metáfora de la tierra se bifurca en una evocación del paisaje y en un campo trabajado, la figura del guajiro se propone como articuladora las metáforas de la sangre y de la memoria. 
Otro de los autores que ha escrito numerosos romances es Ramón Vélez Herrera (1808-1886). Sus primeros textos "Elvira de Oquendo o Los amores de una guajira" 126 fueron publicados en la colección El parnaso cubano (1840) a cargo de Antonio López Prieto $^{127}$. Luego en 1856, publica Romances cubanos, obra en la que incluye otras composiciones como "Guajiro poeta", "El combate de las piraguas", La flor de la Pitahaya, entre otros.

En "Elvira de Oquendo o los amores de una guajira" compuesto por 1237 versos y dividido en XXIII partes, Vélez Herrera coloca como epígrafes en el inicio de algunas secciones versos de Domingo del Monte; de este modo, establece un diálogo con los romances delmontinos, gesto que además puede leerse como homenaje y como tradición, tal es el caso de las tiradas de versos VIII y IX. En el caso de la primera, Vélez Herrera cita un verso de Domingo del Monte "Feliz quien como el montero / a solas mira a su dama" que funciona como anticipación del tema que se desarrolla en los versos siguientes: la presentación de Elvira como una guajira bella y casta y la escena amorosa en la cual es cortejada por el guajiro. En el romance, la figuración de la guajira se realiza mediante tópicos clásicos, como los empleados para describir a la amada en la retórica del amor cortés:
Era la airosa guajira
Donosa, pura y lozana
De esbelto talle, el cabello
Ondeándole por la espalda
En desordenados rizos
Lascivo el viento besaba
Blanca mano, breve pie
Cuello de nieve y de nácar
Ojos ardientes y negros

\footnotetext{
${ }^{126}$ La referencia ineludible es la primera obra romántica de Esteban Echeverría, el poema Elvira o la Novia del Plata, de 1832. En esta composición se canta el amor trágico entre Elvira y Lisardo.

${ }^{127}$ Para esta investigación accedimos a la edición digitalizada de la obra de 1881 .
} 
Boca gentil, tez rosada. $(752-761)^{128}$

Si en esta sección el romance se inicia con la descripción de la guajira, el epígrafe cobra sentido en el núcleo narrativo cuando se menciona que Elvira se ha entregado a su amante:

Sin conocer el amor

Hasta aquella noche infausta.

Con pláticas deliciosas

Entrambos se requebraban,

Reclinados en el tronco

De una bellísima palma.

Allí pasaron las horas

En la soledad encantada

Dormidos en la molicie

Y empapados en el ámbar

Que la fresquísima noche

Derramaba con sus alas,

Al delicioso susurro

Que forma lúbrica el aura

En el árbol y en la yerba,

Meciendo flores y ramas. (764-779)

Al igual que en los romances de Domingo del Monte, la naturaleza se configura como tópico romántico que acompaña el devenir de los protagonistas. En estos versos, el clímax amoroso es descripto a partir de un paisaje idílico, arcádico, de ensueño. La única alusión a un elemento de la naturaleza de manera más específica es la palma, pues en ella se concentra en tanto entidad simbólica, la cubanidad.

\footnotetext{
${ }^{128}$ Estas descripciones de la mujer blanca, pura, virginal, contrastan con las descripciones de las mulatas saturadas de sensualidad que aparecen en el mismo período en novelas como Cecilia Valdés, de Cirilo Villaverde. Al respecto, consultar De Lourenço, Cileine (2002); Álvarez, Inmaculada (2003); Civantos, Christina (2005).
} 
En la sección IX otro epígrafe de Del Monte tomado de su romance "La patria" corrobora la intención de homenaje y de tradición que Ramón Vélez Herrera propone con su romancero. El epígrafe se corresponde con la décima que interpreta el desterrado cuando hace referencia a Cuba:
Allí todo es verde pompa
Todas son siempre galas
Y las auroras de enero
Con las de abril se igualan

El intertexto delmontino funciona como anticipo del tema que se tratará en estos versos en los cuales se configura una naturaleza como paisaje paradisíaco: en una “encantadora mañana" los "pajarillos" cantan "armónicos himnos". Sin embargo, los versos que constituyen este tramo no solo presentan una naturaleza armónica sino también diversa, distinta y peculiar:

Y sobre el frondoso árbol

El ruiseñor en las ramas

Dese su elevada cima

Con voz deliciosa canta

Y se mecen los sinsontes,

Y la tojosita salta,

Alegrando los oídos

Los zorzales a bandadas,

Y los mayos y totíes

Tendiendo las prestas alas

y el hermoso guatiní

cubierto de plumas varias,

desde los frondosos bosques

y las selvas solitaria

sorprende con sus colores

saltando de rama en rama. (814-829) 
En estas secciones caracterizadas por la presentación de elementos de la fauna y la flora cubanas, la voz narradora demuestra su cabal conocimiento de la región y pone en evidencia la particularidad de la isla al enumerar, con cierto sesgo naturalista, las diferentes especies autóctonas. Los siguientes versos corresponden a la sección XV de este romance, que tiene por título "La tumba de monte" y describe, precisamente, el paso de Elvira por un monte talado, cuando separada a la fuerza de su amante, regresa a la casa paterna:

Sitio de duelo y espanto

Donde a los golpes del hacha

Yacen en el mudo suelo

Caobas, cedros y ácanas

El arabo, el chicharrón,

El ateje o la majagua,

Que extermina con su filo

Nuestras agrestes florestas (1330-1338)

$(\ldots)$

Se encaminan al incendio

Que insaciable devoraba,

El sabicú, el guayacán,

El roble, y el quiebra hacha

El ébano, la maoba,

Las jocumas y las palmas. (1384-1389)

Este tramo del romance es singular para analizar la configuración de la naturaleza porque produce una superposición de imágenes. Por un lado, la visión de una naturaleza romántica está presente en tanto que la desolación del monte funciona como analogía con el sentimiento de desgarro y soledad que profesa Elvira al verse apartada a la fuerza de su enamorado. De este modo, cuando caminan Elvira y su padre por el monte, la tristeza de ella se amalgama con una naturaleza que gime, cruje y llora:

Por el llano caminaban

Al continuo rechinar 
De los troncos y las ramas

Y a los quejidos del ave

Que su nido abandonaba

Y con postrera armonía

Sobre ruinas desoladas

Exhalando sus querellas

Mueve las ligeras alas. (1375-1383)

En unos versos más adelante, esta configuración de la naturaleza romántica se explicita:

La expósita desdichada

Suelta al aire sus quejas

$\mathrm{Y}$ árboles, selvas y vientos

Acompañan sus querellas (1538-1541)

Al mismo tiempo, es también una naturaleza exhibida en su peculiaridad distintiva. La toponimia construye una geografía particular, que se define por su clima, su suelo y sus especies. Como señalábamos, una voz conocedora de lo autóctono y regional emerge como autoridad y el romance se convierte en un texto que permite nombrar, clasificar, ordenar el yacimiento natural:

Y el cernícalo cubierto

Con sus cenicientas manchas

Con su monótono grito

Abre chillando las alas

Y vuela del mamoncillo

A la yagruma o la jagua,

De la cúrbana al yaití,

De la higuereta a la yaya.

La tórtola se cobija

En el tronco de una guásima. (1406-1415) 
Una tercera imagen se superpone a las anteriores, la de la naturaleza arrasada. Si Domingo del Monte presentaba una naturaleza industrializada por el ingenio, en este romance, se incorporan otras imágenes sobre la tierra yerma:

A los decretos del hombre

Se ve luego transformada

En un arenal desierto

En una estéril comarca

Sitio lúgubre de muerte

Que en vez de lores lozanas

Solo esparcidos troncos

Ofrece a la débil planta. (1394-1401)

La mano del hombre aparece como la responsable de este arrasamiento, de la tala y quema de los montes y el paisaje paradisíaco se transforma en desierto:

Y sin rocíos ni yerbas

Ni las lluvias esperadas

Será la infelice Cuba

El páramo de Zahara

Donde las arenas queman

Con el sol que las abrasa

Donde ni un árbol cobija

Con su sombra hospitalaria

Al fatigado viajero

En su soledad amarga. (1364-1373)

Pero, a diferencia de los romances de Domingo del Monte, la naturaleza "acciona" y se expresa en una multiplicidad de "voces": ruidos, quejidos, lamentos de plantas, árboles y pájaros generan una naturaleza plenamente sensitiva, visual y auditiva. La personificación como recurso ofrece una naturaleza viva que agoniza:

Yacen postrados en tierra 
Las ceibas y las macaguas

El manajú, la daguilla,

Los copales y las yabas,

Que rechinan al caer

Tendiendo las secas ramas, (1424-1429)

$(\ldots)$

$\mathrm{Y}$ al animado murmullo

De las hojas y las ramas

Y a la voz del pajarillo

Que los oídos encanta

Sucede un triste silencio

Que sólo el hombre profana

Escuchándose en las noches

El eco de sus pisadas. (1446- 1453)

En este mismo romance, también aparece una naturaleza rural que se opone al espacio urbano. En la configuración del campo se establece una relación simbólica entre tierra y guajira: ambas son puras, incorruptas, mientras que la ciudad se caracteriza por la impostura, el engaño, la falsedad. En este sentido, las virtudes de la guajira se correlacionan con las virtudes de la tierra no explotada por el hombre; en estado de "pureza", ambas son dignas de elogios. La tradición literaria aporta numerosos ejemplos de esta correspondencia. En particular, será a partir de la Modernidad y de la emergencia de las ciudadelas cuando el campo se configure simbólicamente como un reservorio de valores, prácticas y virtudes que se contrastan con la corrupción e impureza de la ciudad.

En el caso cubano, la valoración positiva del campo se asocia además a la terrible epidemia de cólera que en 1833 azotó a la isla y provocó solo en La Habana nueve mil muertes ${ }^{129}$. Como señala Julio Ramos, (1996) a propósito de la lectura que realiza sobre la novela de Cirilo Villaverde, Cecilia Valdés,

${ }^{129}$ Ver el artículo de José R. López (2010) “El cólera en Cuba: apuntes históricos”. 
La retórica de la pureza y del contagio no fue estrictamente una invención literaria, remite más bien, a las representaciones del cuerpo y la transmisión articuladas por el discurso higiénico que cobra un papel fundamental en la producción de categorías de límites y territorialidad para la nación futura, particularmente después de la desastrosa epidemia del cólera que azotó a Cuba en 1833 (precisamente en la etapa inaugural del abolicionismo) (30).

La relación entre sujetos y tierra no solo se concibe en términos de posesión, sino que la pertenencia a un terruño opera como indicador de ciertos valores que distinguen a los sujetos. Cuando la literatura pone en evidencia esta mirada sobre lo rural se torna necesario, entonces, analizar el contexto de producción. En el capítulo I recuperamos la mirada que los criollos letrados vinculados con la Ilustración reformista tenían sobre la tierra y cómo los primeros discursos que bregaban por una identidad cubana habían emergido "tierra adentro", en la región oriental de la isla, la misma que Antonio Benítez Rojo denomina "la Cuba chiquita o pequeña". No es casual, entonces, que el romance presente esta dicotomía entre ciudad y campo. Las metáforas de la tierra y de la sangre funcionan para explicar la "pureza" del campo, que no está contaminado con la sangre del esclavo negro, pues es tierra "regada solo por el sudor" del guajiro. A la vez, la industria del ingenio no solo corrompe la tierra con sangre extranjera sino que la arrasa, pues las talas son necesarias para el asentamiento de los plantas de producción. Por otro lado, la ciudad es el espacio signado por la mezcla y la heterogeneidad que atenta contra los "verdaderos valores" y las "costumbres auténticas" del campo ${ }^{130}$. En el romance, Ramón Vélez Herrera enuncia del siguiente modo estas diferencias:

Tal vez sus tiernas canciones

130 En el capítulo I hemos analizado la constitución heterogénea de la sociedad cubana y las clasificaciones de sus habitantes bajo diferentes criterios: por su condición civil, por el color de la piel, por la procedencia, por el origen racial, por la posición económica, etc. (Ortiz [1946]1995; Santamaría García-Orovio 2005). En un artículo muy interesante, Pilar Pérez Fuentes y Lola Valverde (1999) describen las características de la ciudad de La Habana a mediados del siglo diecinueve y destacan que, debido al crecimiento inusitado de la población, ésta comenzó a habitar a extramuros de la muralla de protección que dividía antiguamente el perímetro urbano. A pesar de que la muralla iba a ser derribada en 1833, esto no ocurrió hasta 1863, razón por lo cual, este cerco se convirtió en un límite físico que separaba a los habitantes intramuros (un $26 \%$ ) de los extramuros (73\%). Pero como indican las autoras, la muralla constituía un elemento de separación social, cultural y económica: la oligarquía habanera y las clases acomodadas residían en los barrios interiores y las clases populares, en los exteriores. El artículo expone la compleja movilidad entre los grupos y las clases sociales. 
La hermosa guajira escucha

Reclinada en el horcón

Inocente, fresca y pura,

Libre el pecho de los vicios

Que en las ciudades pululan,

Donde la amistad aleve

$\mathrm{Su}$ amargo veneno oculta,

Donde los hombres se venden,

Se escarnecen y se adulan,

Y bajo un torpe disfraz

Nos engaña la impostura

Donde la humilde plebe

A la nobleza importuna

Respetando unos blasones

Que en el engaño se fundan,

Donde el odioso interés,

Levanta su faz adusta,

Ídolo que reverencian,

Y a quien incienso tributan. (1196-1215)

En síntesis, podemos advertir que esta compleja configuración de la naturaleza cubana que aporta el romancero de Ramón Vélez Herrera se elabora sobre diferentes niveles que se articulan tanto en lo temático referencial como en las posibilidades de representación que ofrecen las corrientes estéticas que rodean su producción. Además, su romancero pretende "hacer tradición” al ligar su obra con la de Domingo del Monte. En este sentido, la intertextualidad que genera el epígrafe coloca en diálogo dos obras. Al respecto, y si traemos a colación las figuraciones autorales analizadas en el capítulo III, notaremos que es importante la marca del epígrafe pues este gesto autoral se relaciona con cierto afán de institucionalización y organización del campo de las letras cubanas que promueve Domingo del Monte y del cual participa Vélez Herrera. El epígrafe como tal es un punto de partida, un principio de interpretación, y al mismo tiempo, proporciona un doble juego de enunciación, pues, por un lado, pone de manifiesto el conocimiento (relacionado al universo de lecturas) de un autor, y por 
otro, es un reconocimiento a quien se cita. El epígrafe "ubica", "sitúa" a los dos autores que mediante ese texto particular se interpelan.

\subsubsection{Tierra, sangre y memoria en la patria guajira}

Si bien la naturaleza aparece como un elemento sintetizador del sentir patrio, hay otros elementos relacionados a ciertas prácticas culturales que permiten diseñar la identidad popular: hábitos y costumbres que definen la cubanidad en términos de identificación colectiva. Es por ello que los romances también constituyen un acervo lingüístico y literario respecto de las prácticas y costumbres de tipo popular. Estos romances escenifican la vida de los guajiros y sus entretenimientos, tales como la riñas de gallo, las faenas en el cañaveral y en los tabacales, las distintas celebraciones y festividades. Cuando en el capítulo I hacíamos referencia a la construcción de la identidad colectiva, señalábamos, precisamente, que la identificación atraviesa distintos niveles: territorial, cultural-histórico y, por último, social. En los romances se advierte esta intención de configurar escenarios locales y populares ligados a las costumbres de los guajiros. Si las figuraciones sobre la naturaleza podían analizarse en función de cómo operaba en los romances la metáfora de la tierra, para analizar las figuraciones culturales, será necesario explicar el funcionamiento de las metáforas de la sangre y de la memoria. Tal lo señalamos en el capítulo anterior, hacia la primera mitad del siglo diecinueve, el costumbrismo y el nativismo ofrece a los escritores una serie de convenciones estéticas que regulan la producción. Los cuadros de costumbres exponen la necesidad de un realismo incipiente, que busca "pintar" el pueblo, poner de manifiesto "lo local". A la vez, esta necesidad encuentra en el Romanticismo la posibilidad de expresión de la subjetividad tanto individual como colectiva. En este sentido, los romances de Francisco Pobeda y Armenteros, Ramón Vélez Herrera, José Jacinto Milanés, Miguel Teurbe Tolón, y José Fornaris sirven como ejemplo de cierta impronta románticocostumbrista. Al respecto, Federico Milanés, en el "Prólogo" a las Obras Completas de Don José Jacinto Milanés señala el ambicioso plan literario que concebía su hermano:

Proponíase en su Mirón Cubano presentar una larga serie de cuadros escénicos, que desunidos de por sí, respecto del motivo argumental, en su conjunto, sin embargo, deberían ligarse estrechamente a la idea primitiva de retratar a nuestra sociedad bajo todos sus puntos de observación, vituperables o dignos 
de loa. Tan extenso estudio de usos y datos curiosos sobre la vida patria, cuyos colores risueños o tristes convergían, por así decirlo, de la luz reflectante en que el poeta se colocaba, embozado con el seudónimo que caracterizaba su movimiento en la vida social (1865: XXXIX).

Aunque José Jacinto Milanés no logra concretar este plan literario, los dramas y las "leyendas" romanceadas que compone tienen esta impronta local, costumbrista. Más adelante retomaremos esta idea cuando analicemos sus romances.

Junto con las fiestas religiosas, en el romancero de Ramón Vélez Herrera, Miguel Teurbe Tolón y Joaquín Lorenzo Luaces se presentan otros eventos de índole popular, tal es el caso de las riñas de gallos. Son varios los escritores que abordan esta temática, pues es evidente que era una práctica muy arraigada en Cuba desde el siglo dieciocho; de hecho, en todos los pueblos y en los campos se habían construido ruedos denominados "vallas" para tal fin ${ }^{131}$. Debido a los desmanes que se producían entre los concurrentes y apostadores, en 1835, el General Miguel Tacón y Rosique dispuso que las peleas de gallo solo se realizaran en los días festivos. Una muestra del valor que tenían estas riñas en la cultura cubana se aprecia en la antología elaborada por Salvador Bueno (1983) Costumbristas cubanos del siglo XIX, en la cual hay un cuadro que se titula "El gallero". Sobre el valor de estos cuadros señala Bueno en el "Prologo":

Precisamente en la década entre 1830 a 1840 sobreviene el verdadero despliegue del costumbrismo literario cubano. Los periódicos y revistas llenan sus páginas con escenas, cuadros y tipos costumbristas. Entregan un fresco animadísimo de la vida colonial. Percibimos entre líneas la existencia de aquellos criollos acomodados en las amplias casonas de antaño, sus paseos en quitrines y volantas por las calzadas y alamedas, asistimos a sus festejos, sus ingenuas reuniones de familia, recorremos las calles soleadas de las viejas ciudades, los campos donde los guajiros laboran en vegas y caseríos. Y chocamos con el espectáculo indignante de una sociedad apoyada en el trabajo esclavo, en los sufrimientos y humillaciones de miles de hombres (XIV).

\footnotetext{
131 El romancero no es el único género que ha perpetuado esta tradición pues es un tema también transitado en la prosa costumbrista. Un ejemplo es la novela corta, de Cirilo Villaverde, publicada como folletín y titulada El guajiro o Amores y contratiempos de un guajiro (1839) en la cual aparece una escena de pelea de gallos.
} 
El autor del cuadro firma bajo el seudónimo Licenciado Vidrieras ${ }^{132}$ y repara en su artículo sobre las características de esta tradición:

Así como la poética Andalucía es sin discusión la tierra clásica de los toreros, Italia de los ciceroni, Méjico de los léperos, etc., la isla de Cuba lo es de los galleros. Su origen se pierde en la noche de los tiempos, pues aunque ni en las obras de Washington Irving, ni en las historias de Arrate y Valdés se halla nada de aquéllos, se sabe de buena tinta que Colón y sus compañeros vieron aquí las primeras peleas, y que desde que la Habana era puerto de Carenas, ha manifestado en todas épocas y circunstancias su decidida afición a los gallos.

Pero no es sólo la capital de la mayor de las Antillas el verdadero centro y punto culminante de semejantes diversiones; en sus vírgenes y olorosas campiñas es donde el genio de la galomaquia ha establecido sus redes, entronizándose y enarbolando su estandarte en los puntos más recónditos, incultos y desconocidos. Si el célebre Gall, descendiente como se ve de la raza galluna, quisiera enriquecer su sistema frenológico, debería analizar los cráneos de nuestros campesinos, y encontraría desarrollado un nuevo órgano desconocido para él, pero que no es otro que el del gallero; y según nuestros humildes cálculos y pobres observaciones, existe aquel órgano en la cuadratura del círculo coronal, en dirección al cerebelo. De lo dicho se infiere que el gallero puro debe ser nativo del país, o lo que es lo mismo, planta indígena; porque son sin duda los más hábiles, aptos, idóneos y expeditos para el oficio. Los conocimientos prácticos que necesita el gallero son grandes y dificultosos. Como capitán a guerra y castellano de casillas, ha de conocer la castrametación, la estrategia y el ataque y defensa. Debe estar perfectamente enterado en la historia y cronología de los gallos; en los principios de higiene, fisiología y patología y en el magnetismo animal; esto es lo más esencial para todo buen gallero, que, además, ha de ser médico y cirujano, botánico y farmacéutico. A estos conocimientos puramente científicos y sublimes, debe añadir el gallero la ligereza, limpieza, y mucha locuacidad, anchos pulmones y gaznate de hierro, agilidad y soltura, especialmente en rodillas, brazos y

132 El seudónimo empleado por el autor también traza relaciones intertextuales con la literatura castellana, pues es el nombre del personaje protagonista de "El licenciado Vidriera" una de las doce Novelas Ejemplares (1613) de Miguel de Cervantes. Si bien, el personaje enloquece y piensa que es de vidrio, el rasgo principal que ostenta es su agudeza, razón por la cual, todos lo toman por consejero. 
manos, con algunos humos de al quimia, que es cosa muy socorrida para la profesión (213-214).

La extensa cita permite acceder a la mirada del costumbrista que recurre al carácter "científico" para explicar el arraigo de esta costumbre y, por otro lado, nos permite situar esta práctica en el seno del campo cubano pues "el gallero puro es nativo del país".

El romance de Ramón Vélez Herrera titulado "La pelea de gallos" (1840) 133 compuesto de 170 versos, presenta al guajiro "Juan Pérez, el de la Vegas" como poseedor de un gallo ganador. El acontecimiento central es la pelea entre el gallo de Juan Pérez y el de Juan Mena. El marco son los preparativos de la riña, la llegada de los espectadores y la presentación de los dueños de los gallos. Los verbos marcan una acción constante, generan suspenso y, al mismo tiempo, evocan la tensión en los apostadores por el resultado:

Pico a pico, espuela a espuela

El prieto se vuelve atrás

El talisayo se acerca

Cuando de un vuelo el de Pérez

Salta y estrecha al de Mena

Clávale el pico, y de un golpe

El corazón le atraviesa

Herido el gallo vacila,

Gira, y las alas sangrientas

Abre y recoge inclinado

En el suelo la cabeza

Pero se encarniza el prieto

Sobre el cadáver pasea

Lo pica, escarba y sacude (134-146)

\footnotetext{
${ }^{133}$ En El Parnaso Cubano (1840) Colección de Antonio López Prieto. La Habana: Imprenta de la Capitanía General.
} 
El tema de la riña aparece también en un romance de Joaquín Lorenzo Luaces, "El tuerto de Guanajay" y en una composición extensa de Miguel Teurbe Tolón, "El Pollo de Juan Rivero" (1856), romance en el cual se detallan los preparativos de la pelea, las características de los gallos, el encuentro y el arreglo de las apuestas tras el resultado. Este romance compuesto por 487 versos, se construye sobre el diálogo que mantienen distintos personajes, permitiendo la incorporación de registros diferentes, pero hay una voz central que ordena la presentación:

Mientras que en la humilde iglesia

Una esquila y dos campanas

Ahorcadas de cuatro vigas

En campanario de yagua

Repicaban anunciando

Al fiel pueblo de Santa Ana

La mañana de domingo

Día de embullo y de guángara. (20-27)

(...)

Mientras así entretenidos

Conversaban a la larga

En el ancho colgadizo

De la tienda se apeaban

Hombres, mujeres y niños

Que a cada instante llegaban

Por diferentes caminos

Y de distintas comarcas:

Ellas con gorras y plumas

Como penachos de palmas

Ellos con machete al cinto

Y bajo el brazo la java

Donde incógnito viene

Algún campeón de la valla.

- ¿sabe uste, compae Anicasio

-exclamó el de Majagua- 
Que esta mañana la gente

Está bajando como agua?

Aguaite allá pa el camino

Y mire aquella parvada

Que deben ser los Pérez

Que vienen de la Siguapa

-¡Digo! Y esa es gente gorda

-dijo don Nicasio - ¡vaya! (66-90)

Una de las hipótesis que sostenemos es que las riñas de gallo constituyen un tema recurrente en el romancero decimonónico porque exponen la heterogeneidad cultural y étnica, pero en un espacio en el cual es posible la convivencia bajo ciertas reglas, "las del juego", que regulan la participación de los sujetos ${ }^{134}$. En este sentido, esta tradición, que en el Caribe tiene una extensa trayectoria ligada a la colonia ${ }^{135}$, permite formular en términos alegóricos la posibilidad de la patria para todos:

Éranse las diez apenas,

Poco después del almuerzo

Y ya el recinto estaba lleno

De gentes de toda clase,

Razas, colores y sexos,

Desde el bronceado mulato

Hasta el carabalí prieto

Desde el astur rubicundo

Hasta el cubano trigueño.

El rico al lado del pobre

El grande junto al pequeño

La blanca y linda doncella

Junto al negro, sucio y feo

\footnotetext{
${ }^{134}$ La riña de gallos es también una práctica de la tradición gauchesca, que ha sido abordada por cronistas europeos "acriollados" como el italiano Pablo Mantegazza (1831-1910) y el francés Alfredo Ebelot (1839-1920). Sus crónicas pueden consultarse en el sitio WEB Tradición gaucha.com.ar

135 “El Gallero" (Bueno 1983: 213- 220).
} 
El mayoral o el sitiero

El sacristán con el cura

El albéiter con el médico

Hijo padre, esclavo y amo

Discípulos y maestros

Todos allí confundidos

Con democrático aspecto

Iguales asientos tienen

Donde igual es el dinero. (231-254)

Sin embargo, en la riña ${ }^{136}$, el dinero aparece como la posibilidad real de participación y pertenencia; en correlato, la patria cubana que los letrados criollos conciben hacia la primera mitad de siglo se piensa en términos económicos, pues es la industria del azúcar la que posiciona a Cuba como potencia en el mercado europeo y, de alguna manera, posibilita su "inclusión” en la Modernidad. Es también la industria del ingenio la que trae aparejada la heterogeneidad racial y la que promueve, al mismo tiempo, la emergencia de discursos que frente a este problema proponen soluciones paradojales.

En relación al planteo respecto de la búsqueda de un lenguaje patriótico y de un género que sirviera para expresar el ideario de una conciencia diferenciada, nos parece oportuno traer a mención lo que refiere Miguel Teurbe Tolón en el "Prólogo" a sus Poesías de 1856. Dice:

Cada país y cada pueblo tienen en su naturaleza física, en su constitución social, en sus tradiciones, en sus costumbres, un tipo suyo propio, esencialmente característico, que los distingue entre todos los demás; y en este

\footnotetext{
136 También se ha ocupado de estudiar la riña el antropólogo Clifford Geertz en el capítulo "Juego profundo: Notas sobre la riña de gallos en Bali" de La interpretación de las culturas (1973), en el cual precisa que, a primera vista, una pelea de gallos balinesa es un enfrentamiento entre dos de estos animales, pero quienes se enfrentan en realidad, según Geertz, son hombres. Desde su perspectiva, los gallos representan hombres y grupos que rivalizan simbólicamente por prestigio social. El sistema de apuestas pone en evidencia la tesitura que sostiene Geertz. Hay dos tipos de apuestas: una central, que tiene lugar entre los dueños de los gallos, y las múltiples apuestas periféricas que se realizan entre el público. La primera es elevada y el resto menores. La primera es colectiva (la realizan coaliciones de personas) y las otras individuales. La primera se lleva a cabo entre las partes con la única mediación del árbitro y las segundas son públicas. La primera es pareja, y las otras suelen ser desiguales. Geertz observa que cuanto más alta es la apuesta central, más equilibrada es la riña, mayor es el número de apuestas periféricas y menor su desigualdad.
} 
tipo debe fundirse la forma de su literatura para que sea verdaderamente nacional (...). Si España tiene sus Romances, Escocia sus Baladas, Francia sus Trouveres -nosotros en Cuba, con su naturaleza, un carácter, unas condiciones sociales absolutamente características de nuestra existencia excepcional, debíamos tener $-\mathrm{y}$ de hecho tenemos - una poesía nuestra, peculiar, de nuestro pueblo, tanto en su esencia como en sus formas, es decir, una poesía nacional, popular, cubana. Las leyendas que ahora por primera vez se dan al público, en forma de libro, no son más que débiles ensayos sobre un género de literatura que debería cultivarse con más esmero por nuestros poetas. En estos ensayos he procurado conseguir dos objetos: $1^{\circ}$ dar a la leyenda el movimiento dramático; y $2^{\circ}$ observar literalmente la verdad del lenguaje con respecto a las personas que hablan, como a las cosas de que se habla. (1977: 284).

Este prólogo tiene un carácter de manifiesto que permite situar la mirada del letrado en este contexto de producción. Domingo del Monte, José Jacinto Milanés y Teurbe Tolón exponen de manera explícita sus preocupaciones con respecto a la emergencia de una literatura nacional que pueda expresar "la verdad" del lenguaje de los cubanos.

José Jacinto Milanés también llamará "leyendas" a sus romances. En el mismo "Prólogo" al que hicimos alusión, su hermano señala que éstas ocupan un lugar menos importante en la obra de Milanés, pero nos interesa rescatar las observaciones respecto del "género", pues se relacionan con el planteo de Miguel Teurbe Tolón:

Las leyendas ocupan el lugar menos prominente. Aparte de sus bellezas relativas de estilo, carecen en sustancia de aquella especialidad idónea con que la inspiración americana de Milanés se desarrolla en sus obras sueltas ó bien la fuerza de sentimiento poético que en sus composiciones dramáticas. Aquellos ensayos, antes que pruebas de grave reflexión en un género diferente de los que cultivaba por vocación, se deben considerar como relaciones rimadas, término medio entre la narración épica y el romance popular de España, que aunque complazcan por el gráfico matiz de alguna escena y la fácil soltura del verso, no logran disimular el principio imitativo del que provienen. Deslumbrado Milanés con la gala descriptiva, con el interés de pictóricos pormenores que ostentaban las leyendas peninsulares, sentíase acometido de la gana de novelar en verso (XXXVII). 
En el caso de Francisco Pobeda, sus "Leyendas cubanas" son una serie de ocho romances extensos que retratan las costumbres guajiras, publicados en 1863. Las composiciones fueron elaboradas en diferentes años, las primeras se remontan a $1831 \mathrm{y}$ las últimas a $1855^{137}$. Algunos de estos romances llevan un título que acompaña la denominación por orden cardinal. También es de mencionar que el orden con el que son presentados no concuerda con la fecha de composición, pues la primera es "Leyenda cubana" (1832), luego le siguen "Leyenda primera. Leonardo Fernández y Lutgarda Flores" (1831), "Leyenda segunda" (1832); "Leyenda tercera. Carlos Bravo y Luisa Aguirre” (1846); "Leyenda cuarta. María y Jesús Contreras” (1833); "Leyenda quinta. La vida del mayoral” (1855); "Leyenda sexta. Juan Pérez de la Rosa” (1833); “El día de la tormenta” (1855) y “Leyenda. La vida del Majagüero” (1855).

La interacción entre la esfera de la oralidad y la escritura que permite el romance se puede apreciar de manera singular en el caso de Pobeda, pues es un autor no culto, campesino ${ }^{138}$. Señala Vitier que "el empeño central de Pobeda era versificar la vida y costumbres del guajiro en el metro que le era familiar, con la esperanza de incorporarse a esa propia vida como cantar anónimo" (2002: 107):

Escribir lo cierto aspiro

Aunque mísero coplero,

Y la espinela prefiero

$\mathrm{Al}$ estilo altisonante,

Para que después me cante

En la sabana el montero (2002: 107)

Si bien la décima era ese metro "familiar", que él conocía por ser un hombre de campo, escribe romances en los cuales también retrata la vida rural. Como sostiene Virgilio

\footnotetext{
${ }^{137}$ Francisco Pobeda (1863) Poesías. Sagua La Grande: Imprenta de Don Antonio M. Alcover.

${ }^{138}$ Los oficios que ejerció Francisco Pobeda ponen en evidencia la superposición de prácticas orales con escritas, ya que fue actor de teatro, empleado de cafetales e ingenios, vendedor de legumbres y viandas y al mismo tiempo ejerció como escribano, notario eclesiástico y maestro.
} 
López Lemus (1997) "la descripción de los guajiros de Poveda" ${ }^{139}$ inicia casi una tradición cuando pinta al hombre de campo en tres clases: una, guajiro estanciero; segunda, el mayoral y tercera y más general, el guajiro sabanero (51).

En "Leyenda cubana" (1831) el romance consta de 128 versos y narra el amor de dos guajiros. Al igual que en los romances delmontinos, la naturaleza, específicamente, la vega, es el escenario donde se desarrolla la historia de los enamorados. Hay un escenario natural, la hacienda, y un escenario urbano, pues como en otros romances de Pobeda, hay una presencia importante de referencias que hacen alusión al pueblo: plazas, ferias, iglesias. Aunque lo regional está presente como un valor, ninguno de estos espacios se reviste de características negativas.

En un potro guajamón

A vueltas por ella anduviera,

Pues la vio en misa un domingo

Que sus padres la llevaban

A ver de Guaracabuya

La feria de tanta fama (11-16)

El núcleo narrativo se concentra en el cortejo entre Jacinta Pérez de Vargas y Joaquín: la declaración de amor, los encuentros y desencuentros, los celos y el desplante final de Jacinta. Parte de estos sucesos se generan en un baile, y otra vez, el guajiro aparece como una figura popular dotada de inspiración y con habilidades innatas para el canto y la poesía, en las cuales demuestra cierta picardía. También en este romance se hace alusión a la entonación de las décimas como forma de expresión más habitual entre los guajiros, pero, en este caso, la referencia queda en la voz narradora, sin que los personajes tomen la palabra:

Érase un baile y Joaquín

Un tiplecito punteara

\footnotetext{
${ }^{139}$ Según los autores críticos que se consulten, el apellido del poeta observa dos maneras de escribirse: Pobeda o Poveda. En esta tesis empleamos la primera denominación, pero respetamos la forma utilizada en las citas de referencia.
} 
Al son del ruidoso güiro

Que forma su consonancia.

Unas décimas de quejas

Allí el amante cantara

Pidiendo en satisfacción

Un cita a su adorada. (33-40)

Los pasos de baile también acompañan las idas y venidas entre los enamorados, de alguna manera, estos movimientos se replican en el cortejo de la pareja:

Y suelta el tiple el guajiro

Y con su Jacinta baila.

Escobilla, taconea,

Y haciendo figuras varias

Los jóvenes de pañuelos

Le cobijan las espaldas. (49-54)

En este romance, la única voz es la del poeta. Esta construcción responde a un interés particular que Pobeda hace explícito en varios textos en los cuales se asume como el "primer trovador cubano". En los últimos versos del romance, el poeta hace explícito su función de cantar a Cuba, y en ese canto, establecer diferencias con España que son articuladas desde la autoridad de poeta, que se erige como figuración central:

Estas son las vegueras

De Agabama caudaloso

Castas, lindas, hechiceras;

Tan honestas y sinceras

Cuanto en su trato amistoso

Bellas cubanas que adoro (109-114)

$(\ldots)$

Las del tajo en las riberas

Con su gracia pastoril

¿serían tan sandugueras, 
Como son nuestras vegueras

En esta tierra de abril?

Serían lo mismo acaso,

Pero se diferenció

En que aquellas las cantó

El divino Garcilazo

Y estas las canto yo. (119-128)

La afirmación de que la naturaleza se interioriza en la poesía en el mismo momento en que se inicia un proceso de construcción de la identidad nacional es una idea elaborada por Cintio Vitier pero también sostenida por otros críticos cubanos. En el caso de José Lezama Lima, nos interesa señalar que en La expresión americana (1957), en la cuarta conferencia "Nacimiento de la expresión criolla" manifiesta que el paisaje es el que constituye al ser americano. Para Lezama, quien sigue los postulados de Friedrich Schelling, en cuanto a la unidad del Espíritu y de la Naturaleza en un Absoluto, el paisaje se convierte en un espacio gnóstico, a través del cual el ser humano puede llegar a conocer. Destaca a Martí, Rubén Darío y César Vallejo como los poetas que configuran desde el lenguaje, el paisaje criollo americano, en una mezcla de "estoicismo quevediano y estilo gongorino" (1993: 137). Además, Lezama toma como ejemplos de esta relación entre paisaje y conocimiento los corridos mexicanos, los cielitos de Hidalgo, y el Martín Fierro de José Hernández, obra que muestra con excelencia el vínculo entre hombre y paisaje. Esta misma idea de simbiosis entre poesía y naturaleza se trasunta en otra de sus obras, Antología de la poesía cubana del siglo XIX (2002) en la cual Lezama recupera la relación directa entre escritores y naturalistas:

Los comienzos del siglo XIX están marcados por los dos viajes de Humboldt a Cuba. Su primera visita fue en diciembre de 1800, después volvió en abril de 1804. Se relaciona con lo más culto de la sociedad cubana de su época. En 1807 publicó su primer libro, en el que trata de nuestra isla, titulado Viaje a las regiones equinocciales del nuevo continente del que en 1826 se publicó un capítulo, Ensayo político sobre la isla de Cuba. Nosotros hacemos referencia a esa obra, no solo por la significación que tuvo en todos los órdenes sino por las 
valiosas observaciones que hace sobre nuestra naturaleza, todas ellas de raíz poética. Sus conclusiones científicas nos llevan casi a la afirmación de que nuestra poesía tiene una raíz natural, que la naturaleza es poesía, creación por la imagen. La pureza de nuestro aire, comprueba Humboldt, adquiere una tonalidad azul pálido que solo se pueden comparar a la que ofrecen algunas regiones del mediodía en Italia, y de ese azul, concluye la observación de Humboldt se desprenden los objetos lejanos con un relieve extraordinario (2002: $17-18)^{140}$.

Si en el romancero de Domingo del Monte la naturaleza se convertía en paisaje evocado, con un impronta romántica pero también con sesgos neoclásicos: "De la estación en que al suelo/desde Tauro ardiente lanza/ sus rayos fogosos Febo" ("El montero de la sabana"); en Pobeda esa construcción de la metáfora de la tierra, en correspondencia con cierta intención "criollista o nativista", se torna más realista, con descripciones sencillas que se articulan con escasos adjetivos. El campo y el pueblo son los escenarios naturales por los cuales anda el guajiro y la función del poeta es “escribir lo cierto", es decir, sus costumbres. En este sentido, la poesía de Pobeda está más cerca del tono sencillo que Milanés procuraba para la poesía del pueblo. El rechazo al estilo "altisonante" que Pobeda explicita tiene que ver con recrear en la literatura el tono y la voz del pueblo. Si bien José Jacinto Milanés manifiesta esta preocupación por el rasgo popular que debe tener una poesía que sirva para "espejar las costumbres del pueblo", sus romances, como los de Domingo del Monte, ponen en relieve cierta artificialidad, razón por la cual, los críticos como Lezama Lima y Vitier ven en estos escritores intentos por "cubanizar la poesía" que no logran fraguar en una verdadera poética de lo cubano.

En el caso de Pobeda, además, es interesante señalar el trabajo literario en torno a los distintos registros lingüísticos que reconoce en la sociedad cubana de su tiempo. Su preocupación por "decir lo cierto" se corresponde con una elaboración literaria que plasma diferentes formas de hablar. Tal es el caso de la "Leyenda cuarta. María y Jesús Contreras" (1832) en la cual presenta una serie de acontecimientos que

\footnotetext{
${ }^{140}$ En la versión original el énfasis sobre las palabras Humboldt es señalado con itálica.
} 
ocurren en la fiesta popular de Mayarí. En ese marco pone en escena distintas voces que en plena fiesta pregonan sus productos:

Cada cual a un mismo tiempo

Su preocupación pregonaba

-a los buenos alfajores

-avellanitas tostadas

-ponche de leche. Confites

-a las sabrosas viajacas

-fresquecitas, fresquecitas

-¿quién entra que uno me falta?

-Señores, ahora ha venido

El figurín de las damas

El dieciocho, uno con ocho

¿Usted gusta de algo, mi alma?

-treinta y cuatro, par y prieto

-vino el sol que nos ampara

-Voy Guanajay.-no voy doble

-Que no: la peseta es falsa

-que se enfría este lechón

-ve y cómprate una baraja

-écheme usted vino seco

-a mi aguardiente de caña

Tal era la confusión

Que la gente ocasionara

En la fiesta de la cruz

Todo era bulla y jarana (Parte III, 23-46)

La inclusión de las voces en un mismo nivel, sin que el autor establezca jerarquías ni distinga a quiénes pertenecen provoca el efecto de superposición, mezcla, confusión. Esta manera de presentar la oralidad sin marcas textuales, tales como el uso de itálicas, que connoten ciertas valoraciones proyecta en el romance la condición colectiva y popular de la fiesta y genera en el lector un efecto de cercanía con lo que se narra: la 
oralidad rodea al lector y lo traslada a la celebración misma. Pero, por otro lado, podemos pensar que la representación de la oralidad implica "una estrategia de contención, un intento de dominar la caótica espontaneidad y dispersión del habla popular mediante la codificación y la implementación pedagógica de la ley de la lengua" (Ramos 1996: 12).

Mientras que en la literatura posibilita la emergencia de la heterogeneidad lingüística, el surgimiento de las gramáticas se corresponde con una necesidad de imprimir racionalidad al caos de la lengua. El cambio, ligado a las instancias dialectales y locales de la lengua pone en evidencia la irregularidad, mientras que las gramáticas pretenden instituir una estructura coherente y ordenada. Al respecto, recordemos que en este período, según el registro de Antonio Bachiller y Morales en Apuntes para la historia de las letras cubanas (1859) se publican varias gramáticas, desde la Gramática Latina en castellano en 1814 al "Método breve y fácil para enseñar a leer en poco tiempo, de D. Juan Olivella y Salas publicado en 1828, al que se suma en 1830 la obra Sucinta idea sobre el fácil y sencillo método para aprender y enseñar a leer en muy corto tiempo, de Nicolás Ruiz Palomino y, en 1831, la Nueva gramática de la lengua castellana para el uso del colegio Buenavista que también pertenece a Juan Olivella y Salas. Asimismo en el capítulo II mencionábamos la preocupación que ostenta Domingo del Monte respecto de la publicación de una gramática y del diccionario de voces cubanas cuando asume como secretario de la sección de Educación y Literatura de la Sociedad Económica.

En este sentido, vuelve a ser operativo el análisis de Ramos respecto de Andrés Bello cuando señala que:

En términos de la construcción del orden moderno mercantil, la gramática no es meramente un "reflejo" de cambios "infraestructurales" o económicos de la nación. Complementado por otros dispositivos que intervienen en la administración lingüística — como la ortografía y la sistematización de la nomenclatura de pesos y medidas - el discurso gramatical posibilita esos cambios infraestructurales contribuyendo a racionalizar y a satisfacer las condiciones jurídico-lingüísticas presupuestas por el orden mercantil. También ligada a la constitución jurídico-política de la nación, la segunda función estatal de la gramática se relaciona con la escritura de la ley (1996: 15). 
Ley que - Ramos entiende - posibilita la invención de la ciudadanía, pues esta categoría no es dada a priori, es más bien "un campo de identidad que debía construirse precisamente en la transformación de los materiales 'bárbaros' e indisciplinados de las poblaciones" (16). Sin embargo, la relación entre lengua y ciudadanía rebasa lo instrumental, es decir, el manejo de un código estándar para el ejercicio de la ciudadanía, porque la lengua - la educación literaria y gramaticalcontribuye a la internalización de la ley, "racionalidad que es inseparable del bien decir".

Tal como analizamos en el capítulo anterior, la búsqueda de un lenguaje nacional conlleva la tensión permanente entre lo universal, estándar y lo local, "que se desvía de esa estandarización". Esa fisonomía como la particularización de una categoría general o universal también se advierte en el plano de la lengua:

Sólo a partir del uso y del accidente que sufre la norma lingüística en la oralidad, es posible precisar el territorio de lo propio, la fisonomía o el genio particular del idioma nacional. De ahí que, a pesar del terror que en Bello produce la dispersión y la materia accidentada, fluida, de la oralidad, al mismo tiempo, el desvío efectuado por la palabra oral en su temporalización de la norma es la condición que posibilita la fisonomía nacional (Ramos 1996: 1920).

En el caso del romancero cubano, notamos diferentes actitudes frente al habla dialectal, esa que es la Otra respecto de la gramatical. En el caso de Pobeda, podemos pensar en una actitud contenedora de esa diferencia. Pero, la dicotomía que plantea la mirada de la otredad no basta para explicar un espacio multilingüe, caracterizado por la heterogeneidad y el conflicto. Por eso, podríamos referir que en el romancero se significa una Otredad de la Otredad, la lengua de los negros esclavos. ¿Cómo se ficcionaliza esta diferencia? ¿Cómo se marca la frontera del "bien decir”? En el apartado siguiente, analizaremos en los romances de José Jacinto Milanés, Miguel Teurbe Tolón y José Fornaris cómo se resuelve en el plano literario la presencia de las voces de los negros. 


\title{
4.3. Voces blancas, cuerpos negros
}

La emergencia del ingenio como tema en los romances instala un imaginario de identidad que liga y desliga a los sujetos a un proyecto de patria. En los romances que analizamos, observábamos que la metáfora de la tierra se corresponde directamente con las metáforas de la sangre y la memoria, pues operan de manera relacional, vinculando campos semánticos y organizando esferas de significación que se interpelan.

En el romance "La Patria", de Domingo del Monte, aparece la idea del campo explotado por la industria del ingenio y la crueldad de la esclavitud, en la voz de un sitiero que, desde el destierro, recuerda su campo "solo regado con el sudor de su frente". Pobeda y Milanés también escriben romances en los cuales el tema es la vida en el ingenio. Nos preguntamos, al respecto, qué sujetos y representaciones se recuperan en las figuraciones sobre el ingenio plasmadas en este romancero decimonónico.

En el caso de Pobeda, el extenso romance compuesto por 557 versos se titula "La vida del mayoral" (1855). La extensión se corresponde con el minucioso detalle de la faena del mayoral llamado Severino. El tema central del romance queda expresado en los versos finales:

\author{
Esto es lo más general \\ Y aún no están los huecos llenos \\ Pero he pintado imparcial \\ Poco más o poco menos \\ La vida del Mayoral (552 -557)
}

En la imagen del mayoral que se configura en este romance se exponen sus virtudes por medio de epítetos "de la casa principal / salió el mayoral prudente / el mayoral diligente / el exacto mayoral" (284-287)"; por la acción directa: "Apunta el mata gañanes / por el nebuloso oriente / cuando empieza diligente /el mayoral sus afanes" (1-4), o bien, por las valoraciones que realiza la voz narradora y que lo caracterizan como un servidor leal, cumplidor, eficiente y obediente: 
Le sirve otro café

Y él echando el ojo ve

Cómo viene la negrada

Como que es inteligente

Echa de pronto una ojeada

Y no se le escapa nada

Y pone en fila a la gente (25-32)

El romance se construye a partir de una concatenación de acciones que tienen que ver con el trabajo diario que realiza el mayoral. El episodio central es el enfrentamiento entre el mayoral y el dueño del ingenio - un conde - cuando Severino le presenta las quejas por las raciones de comida. Esta queja tiene por objeto exponer el carácter noble del mayoral, que le reclama al amo por el alimento que recibe "la negrada". Como consecuencia del enfrentamiento, el conde echa al mayoral pero interviene la condesa a su favor y, finalmente, el mayoral se queda en el ingenio, justo a tiempo para la zafra. Como recursos retóricos, la acción se sostiene en diálogos que otorgan dinamismo y tensión a la narración. Además, el diálogo posibilita la presencia de otras voces que son entrecomilladas para marcar las fronteras entre los discursos. De este modo, se exponen distintos tonos y registros bajo los cuales se ficcionaliza la oralidad. Por ejemplo, entre el mayoral y el conde:

¿con esa desfachatez

Se habla a un hombre como yo?

¿con estilo tan soez?

-señor, de faltar no trato...

Yo le he respetado a Usía...

Y si mi cuenta pedía

Es deber, no desacato (219- 226)

O entre una esclava y el mayoral:

Corriendo venía una esclava

Conduciendo el parlamento 
-Mi amo, mayorá, siniora

Que va sumercer allá

-¿La señora? ¿dónde está?

-en el jardín con la frora (331 -336)

Pese a la presencia de una pluralidad de voces: la del mayoral, la del conde y la condesa, la de los esclavos, en el romance hay una voz que marca la jerarquía de los sujetos y también pronuncia valoraciones, con las cuales "dirige" la atención del lector. Esa es la voz del narrador:

Vuelve alegre la negrada

Pues es la hora designada

Para repartir las raciones.

Reconoce el mayoral

Aquel grosero alimento

$\mathrm{Y}$ echa la vista al momento

A la casa principal.

"vamos a ver al señor

Dios me la prepare buena"

Aquí comienza una escena

Que recomiendo al lector. $(115-125)^{141}$

El mayoral aparece en este romance como el personaje más noble y "cubano". La condesa y el conde son "extraños" que no viven en la estancia sino que llegan de visita,

Temprano al siguiente día

Llegó el amo y la señora

Y la turba aduladora

Que al señor conde seguía (85-88)

${ }^{141}$ El énfasis está marcado en el texto original. 
Quien verdaderamente se hace cargo del ingenio es el mayoral y, por eso, cuando llega el maquinista y el maestro de las máquinas ("gentes extrañas") que ponen en funcionamiento el nuevo trapiche y, la zafra es exitosa, los condes le reconocen al mayoral la buena faena y la lealtad. Por otro lado, la presencia de la máquina también expone el proceso de industrialización que atrae aparejado el ingenio:

Ya con la máquina lista

Echa caña en el trapiche

¿Dios quiera que no se achíche

Este día el maquinista!

En la casa principal

Un convite se prepara

Con magnificencia rara

Con lujo casi Real.

Es general la alegría,

Todos entran, salen, vuelven,

Máquinas y trenes revuelven

Porque es de gozo este día.

Embisten a todo trapo

Aquellas gentes extrañas

Unos pocos a las cañas

La mayor parte al guarapo. (481 -496)

Si los condes y los maquinistas son "gentes extrañas" que llegan al cañaveral para la zafra, el mayordomo es el hombre local, que permanece y conoce la tierra, es el "cubano" autóctono:

Y partiendo cabizbajo

El mayoral Severino

Sucumbiendo a su destino

Torna de nuevo al trabajo

(...)

$\mathrm{Y}$ aquel sufrido cubano

Sin odio en el corazón 
Retorna a su habitación

Más satisfecho que vano (409-420)

Sin embargo, otro grupo social se configura en este romance: los negros esclavos. Sus voces también se identifican en una ficcionalización de la oralidad que busca representar al "otro" en un registro lingüístico "diferente". En un ejemplo anterior citábamos el parlamento de una esclava, en ese caso, la marca de la oralidad pone el acento en cierta forma de expresión que no se condice con la norma del "correcto hablar".

Otros esclavos también se expresan y toman la palabra, son los "asalariados". El trato del mayoral con sus esclavos asalariados es diferente del trato que mantiene con otros negros, pues los trata de "caballeros". Cuando el conde echa al mayoral, sus esclavos quieren partir con él, actitud que pone en evidencia la fidelidad de los negros $\mathrm{y}$, al mismo tiempo, el trato que tiene el mayoral como amo:

Mando a cargar su carreta

Acomodando el reparto

De sufrir estaba harto

Y ya nada le sujeta (300-303)

Dijo: -la cosa es completa:

Las hembras en la carreta

Y los varones al trote.

Que cinco esclavos tenía

En la finca asalariados

Robustos y acostumbrados

A trabajar noche y día

-¿Qué es esto? Preguntan todos

-¿No lo miráis? Que me voy

Pues nosotros también hoy

Perdemos los acomodos

¿Por qué, caballeros? Otros

Saliendo tú, se quedarán

Pero si a tí te separan 
Nos despedimos nosotros
Por tí en el ingenio entramos
Cuando en la tienda nos vimos
Y por tí también salimos
Y a donde tú fueres, vamos (309-328)

Recordemos que en el capítulo II analizamos las propuestas de José Antonio Saco y Domingo del Monte sobre el trabajo asalariado en los ingenios como una forma de detener el tráfico negrero. En este romance, el grupo de esclavos asalariados ostenta una actitud de lealtad que se distingue de otros esclavos cuya nominalización alude al conjunto, como una masa de gente que no tiene voz, solo cuerpos para trabajar y obedecer órdenes. A continuación ejemplificamos con algunos versos esta denominación colectiva que quita el rasgo de subjetividad y singularidad al negro, para convertirlo en cuerpo: "Vé cómo viene la negrada" (28), "Vuelve alegre la negrada" (115), "La carne no está muy buena/Y el platanero no fía” (194-195), “Hola, Jacinto, Clemente: / Que venga toda guinea" (239-240), "Señora me ha abochornado/Y hasta los negros me echó” (360), “Toca la campana/salen los negros en pelotones" (413414). En el sentido expuesto, la figuración del esclavo pone en evidencia un doble rechazo, tanto por su condición de objeto que le pertenece a un sujeto, como por su origen. De este modo, se elabora una retórica de la inferioridad que justifica la esclavitud. Por un lado, con el colectivo "guinea" se explicita el origen y, con ello, la extranjería, la no pertenencia a la tierra, en tanto que con la metáfora de la "carne" se alude directamente a la materialidad, a lo corporal. La metáfora de la carne subsume la metáfora de la sangre, pero en el caso del esclavo es una sangre "otra", despreciada, ajena.

Por el contrario, en el romance de José Jacinto Milanés "El negro alzado" $(1835)^{142}$ se presenta otra figuración sobre el mayoral: como amo es tirano y agresivo

\footnotetext{
${ }^{142}$ Federico Milanés en el "Prólogo" a las Obras completas de su hermano, señala que la producción de José Jacinto se extiende desde 1836 a 1843, luego pierde la razón, aparentemente, por enamorarse de una prima y no ser correspondido. En las páginas de ese "Prólogo" también explica con detalle el encuentro entre su hermano y Domingo del Monte y la profunda influencia que éste último ejerció en la obra de José Milanés.
} 
y trata a los esclavos con crueldad. Si, en el romance de Pobeda, los primeros versos retrataban la faena infatigable del mayoral que se iniciaba con la primera luz del sol, en este romance, los versos iniciales muestran una escena donde se advierte la severidad y la autoridad del mayoral como amo, pues él está sentado y su mujer, los hijos y los esclavos, alrededor:
A la puerta del bohío
Sentado está el mayoral:
Gotas de sudor le corren
Por la patilluda faz:
Yace su sombrero en tierra,
Y en su gruesa mano está
Grueso manatí, adornado
Con un puño de metal (1-8)

En este romance se presenta cómo un mayoral imparte castigo a los negros esclavos. El romance se construye a partir de una dinámica teatral de voces. Los primeros versos cumplen la función de presentación de la escena. El yo narrador que estructura el romance presenta la voz del mayoral de un ingenio que está tras los pasos de un negro, Julián, quien se ha dado a la fuga. En los diálogos del mayoral con su mujer se presentan los tormentos a los cuales ha sido sometido el esclavo fugado. En este sentido, el contraste con el romance de Pobeda también se evidencia en las acciones. Mientras que en la construcción de los versos del romance "La vida del mayoral" predominan los verbos que indican las tareas diarias que lleva adelante el mayoral relacionadas con el mantenimiento del ingenio, en el romance de Milanés, las únicas acciones que realiza el mayoral son la vigilancia, la persecución y el castigo. La figuración negativa del mayoral se refuerza con la crueldad que ejerce sobre el pequeño esclavo, la deshumanización también se connota en el apelativo, pues llama al pequeño "perro":

Por otro lado, esta percepción del poeta atormentado y partido en dos "Milanés sol / Milanés luna" es reelaborada por Virgilio Piñera en el poema "A José Jacinto Milanés" (1974) que integra su libro La isla en peso (2000: 187). 
Dos chiquillos cerca de ella

Con un negrito a la par

Todos tres desnudos, juegan

Retozan, gritan, se dan,

Y cada vez que el negrito

Amenaza a algún rapaz

El gran manatí del padre

Que los mira retozar

Levanta en su tierna espalda

Doloroso cardenal (19-28)

El mayoral se sonríe

Y grita: "perro, anda acá:

Entretén a mis hijos" y alza

El instrumento fatal:

A cuya vista, temblando,

Vuelve el pobrecillo atrás

Entre dolientes sollozos

Que tiene que refrenar

$\mathrm{Y}$ virtiendo de ambos ojos

Lágrimas que risa dan,

A los pies de su verdugo

De nuevo se ve llegar. (35-46)

En el romance de Milanés, los términos locales que hacen referencia a las prácticas que se desarrollan en el ingenio son marcados con itálica al igual que las expresiones coloquiales que pronuncian el mayoral y su mujer. Las marcas sobre la escritura permiten establecer una distancia con respecto a lo referido. En este caso, la voz narradora desaprueba la crueldad y la ferocidad del mayoral:

-¿Con tres pelas que ya lleva

No acaba de escarmentar?

-nada: los cujes de yaya

Que destrozé sin parar 
La vez pasada en sus carnes

No me puedo acordar ya

Cuántos fueron; pero apenas

se pudo el perro parar,

cuando volvió al monte

en busca de su mujer Soledad (59-68)

El diálogo entre el mayoral y su mujer pone en conocimiento el enojo de éste porque uno de sus esclavos, el negro Julián, se ha escapado al monte para encontrarse con su mujer. La animalización del esclavo recae en el mote "perro" y su condición de enamorado se reduce a "estar alzado", pues como dice el mayoral:

En un esclavo no hay

amor que valga: que sude

trabajando sin cesar

porque para amar a nadie

no tiene tiempo jamás (88-92)

El origen justifica su sometimiento:

-Por supuesto. ¿Quién le manda

Haber nacido gangá? (93-94)

El negro alzado que se escapa al monte para encontrarse con su mujer es animalizado. Sin embargo, el mayoral también es deshumanizado a ser "convertido" en el romance en un ser infernal, cuya ferocidad reside en la soberbia y crueldad con la cual espera castigar al negro Julián. La metonimia metafórica opera exponiendo la corporeidad de un sujeto que por la práctica de la esclavitud se vuelve "animal": los movimientos de los dientes y las patadas muestran su enfurecimiento. Las venas sirven como metáfora de la sangre encolerizada y todo se resume en una figuración bestial.

En el romance de Pobeda el mayoral era un "cubano" sufrido, un trabajador eficiente y leal, justo, sumiso pero valiente. Por el contrario, en este romance, el cubano es un "buitre", el sentido de la animalización recae en la sentencia de la voz 
narradora que moraliza sobre la esclavitud e invierte los estratos: el negro humanizado se escapa por amor; el mayoral, en cambio, convertido en un animal feroz, acecha a la presa y la somete:

Le tengo de ver pelar

Con el mayor boca - abajo

Que se dio ni se dará

Sus ojos al decir esto,

Llenos de ferocidad

En sus órbitas saltaban:

Oíanse rechinar

Sus dientes: su pie pateaba:

Abultábanse en su faz

Rojas las venas, y era

Una expresión infernal

De ira y alegre soberbia

La que dejaba ostentar,

Tal como el buitre cubano

Que baja raudo y voraz

Al ver el reptil que brilla

Removiendo el muladar. (104-120)

En el romance de Pobeda, no se proyecta una figuración negativa de la esclavitud, "negrada alegre", pues el acento está puesto en el mayoral como el criollo cubano que trabaja para el ingenio y demuestra con esa labor el amor a la tierra. En cambio, a Milanés, por ser un autor mucho más cercano a Domingo del Monte (y por ende, a sus ideas reformistas) la figura del mayoral le permite reflexionar sobre la esclavitud y denunciar la doble deshumanización del sistema, en tanto práctica que animaliza a esclavos y amos.

La retórica en contra de la esclavitud hace "aparecer" tempranamente en los romances la figura del negro (de manera anticipada, si se piensa en movimientos culturales y literarios como el movimiento vanguardista cubano de la "negritud" de las primeras décadas del siglo veinte, o incluso, históricamente, si se remite al año en que 
se logra la Abolición de la trata en la isla, 1886). Pero la evocación no es la del negro como otro tipo étnico-social cubano, sino como el africano - esclavo. En este sentido, y en correspondencia con la narrativa antiesclavista del período, en los romances cubanos no se le da voz al negro sino al esclavo, esto implica una disolución de la identidad étnica y cultural que expone la negritud sólo como cuerpos usufructuados, figuración que responde a los intereses políticos y económicos que sostienen sus autores. De este modo, al mismo tiempo que la literatura producida por el grupo de Del Monte denuncia el uso del cuerpo del negro en tanto cuerpo esclavo, la escritura de este período pone en evidencia también un recurso de apropiación en igual término, es decir, usa simbólicamente el cuerpo negro. Es un uso letrado del negro (de su cuerpo y de su voz), un uso controlado y censurado. En el lúcido capítulo "Lengua, cuerpo y subjetividad", Julio Ramos señala:

Por el reverso del silencio al cual la tortura reducía el lugar del esclavo, el orden emergente proyectaba, inicialmente en la ficción y en los debates jurídicos sobre el testimonio de subalternos, la transformación del esclavo en sujeto de discurso, sujeto en tanto capaz de hablar y reflexionar sobre su cuerpo. No es casual, en ese sentido, que el momento inaugural del género antiesclavista en el círculo de Del Monte, fuera la interpelación del esclavo Juan Francisco Manzano; su relato autobiográfico, de marcado tono confesional, fue escrito en respuesta a la exigencia por parte de los letrados reformistas de un testimonio sobre la tortura y la brutalidad del régimen esclavista (1996: 26).

Por otro lado, consideramos que los aportes teóricos de Raymond Williams (1997; 2001) en torno a las nociones de "estructura del sentir" y "tradición selectiva" nos permiten hipotetizar respecto de la irrupción de la voz del esclavo en los trazos de la literatura. Ante todo, Williams entiende por hegemonía todo un cuerpo de prácticas y expectativas en relación con la totalidad de la vida: "un sistema de significados y valores -fundamentales y constitutivos - que en la medida en que son experimentados como prácticas parecen confirmarse recíprocamente" (1997: 131). Según su concepción, la hegemonía es un complejo efectivo de experiencias, relaciones y actividades que tiene límites y presiones específicas y cambiantes (134) y es, por lo tanto, un proceso activo. Este proceso puede ser resistido, alterado, 
desafiado, razón por la cual, también se advierten prácticas contrahegemónicas. La hegemonía como tal supone una interconexión y una organización de valores que se incorporan a una cultura significativa y a un orden social efectivo. En el proceso de incorporación de esos valores interviene lo que Williams denomina "tradición selectiva", que es una "versión intencionalmente selectiva de un pasado configurativo y de un presente preconfigurado que resulta poderosamente operativo dentro del proceso de definición e identificación cultural y social" (137). Es decir, es un proceso de organización social y cultural que se da dentro de una hegemonía particular y que implica un mecanismo de selección y de exclusión por parte de la clase dominante de valores, significados y prácticas según sus intereses. En este sentido, es una versión del pasado que se intenta conectar con el presente y ratificar. En esa función conectiva y organizativa de lo simbólico y sus prácticas, es decir, la constitución de tradiciones, juegan un rol decisivo las instituciones (por ser las "encargadas" de la socialización) y las formaciones (movimientos y tendencias conscientes y efectivas en la vida intelectual y artística). Según lo entiende Williams, la tradición selectiva es un proceso activo poderoso, en cuanto está ligado a una serie de continuidades prácticas, y vulnerable al mismo tiempo, puesto que se descartan y diluyen áreas de significación totales, aunque esos registros puedan recuperarse.

Por todo lo expuesto, pareciera que, en principio, la noción de estructura del sentir surge en Williams, de la necesidad de hallar un término que dé cuenta de la innegable experiencia del presente, de lo que escapa o parece escapar de lo fijo, lo explícito y lo conocido, es decir, lo social instituido. Es, por tanto, un tipo de sentimiento y pensamiento efectivamente social y material, en una fase embrionaria antes de convertirse en un intercambio plenamente articulado y definido. En consecuencia, las relaciones que establece con lo articulado y definido son excepcionalmente complejas (1997: 153).

Con el término "estructura de sentir", R. Williams plantea, por un lado, la idea de estructura, esto implica un grupo con relaciones internas específicas, entrelazadas y, a la vez, en tensión. Por otro, expresa la idea de "experiencia social en proceso" (muchas veces no reconocida como social, sino como privada y aislante) la cual tiene sus características emergentes, conectoras y dominantes y, ciertamente, sus jerarquías 
específicas (1997: 155). El espacio de las artes y la literatura constituye uno de los campos simbólicos en el cual pueden rastrearse estas estructuras de la experiencia en proceso. En este sentido, Williams encuentra "razones sociales que, presionando desde afuera de la literatura pero desatando dentro de ella transformaciones sociales, inducen cambios en las convenciones" (2001: 18). De esto deriva que las estructuras del sentir permitan captar los campos de la acción social comprometidos en un desafío al orden existente y en función de esto, expresen "un horizonte de posibilidades".

Por lo antedicho, la noción de estructura del sentir permitiría explicar cómo esta relación entre experiencia e ideología se da de un modo contradictorio y perturbador, puesto que, al mismo tiempo que se escucha la voz poética del esclavo en un momento histórico en que el esclavo no tiene voz, lo cual puede entenderse como "fuga del arte o la literatura que anticipa un proceso posterior", esa voz esclava se manipula y controla, dando cuenta de las condiciones históricas materiales en las cuales se produce el discurso literario. Los romances, en tanto escritura literaria, ponen de manifiesto esas instancias de fractura tanto como los aspectos remanentes o residuales de las condiciones materiales de producción; en este caso, la presencia en el romancero de cierta matriz simbólica que revaloriza un pasado rural pre-industrial. En este sentido, el romancero decimonónico despliega todo un itinerario temático en el cual la identidad colectiva patriótica se funda en torno a la figura del criollo guajiro y a la construcción del espacio del campo (la sabana, el monte, el cañaveral) como paisaje y como tierra usufructuada. Atendiendo al proceso de tradición selectiva, ciertos tópicos se instalan y funcionan como matrices configuradoras de una subjetividad colectiva que se ajusta a un orden hegemónico. En este sentido, los letrados que producen el romancero mantienen vínculos ambiguos y contradictorios con el poder y con la clase dominante. En palabras de Williams, obedecerían al carácter dinámico y material de los procesos culturales y simbólicos. Mientras que existe una relación explícita con la sacarocracia cubana, que conlleva a que el grupo de escritores nucleados en torno a del Monte exprese una voluntad política que puede identificarse con los intereses de la elite criolla azucarera, se da un proceso paralelo de alejamiento de estas ideas que se materializa en una escritura programática de significación opuesta. En correspondencia, en el cuerpo de la escritura de los romances se advierten dos 
tendencias que regulan la dinámica del poder. Por un lado, una asimilación de los valores, prácticas y significados que registra la elite criolla de la industria azucarera; por otro, un rechazo de esas mismas prácticas y valores, en función de adscribir a los valores del pequeño productor, del criollo campesino. En el cruce de estos dos sentidos, se instala la experiencia en tanto presente y las estructuras del sentir reflotan en el cuerpo de la escritura como dislocación. De modo que, mientras en el cuerpo escriturario, la práctica de escribir deja huellas respecto de las tensiones entre la "tradición" (tal lo entiende Williams, lo construido "exitosamente" como pasado) y lo "nuevo", entre lo dado instituido y aquello que se intenta instalar, surgen en ese mismo cuerpo de escritura elementos no conscientes, que quiebran, distorsionan los binomios simbólicos mencionados.

En el caso de "El negro alzado", en el romance se advierte una relación entre el tema y la estructura, pues se relata cómo un mayoral imparte castigo a los negros esclavos mientras que el diálogo en el interior de la composición recrea la dinámica de las voces de los personajes que entran en escena, a las que se suma la del narrador. Los primeros versos cumplen, de este modo, la función de presentación. El yo narrador da lugar a la voz del mayoral de un ingenio que está tras los pasos de un negro que se ha fugado. En los diálogos del mayoral con su mujer se presentan los tormentos a los cuales ha sido sometido el esclavo fugado. Las cursivas empleadas en el texto cada vez que se nombra un castigo ("boca abajo") o la forma en que el mayoral llama al esclavo "perro", son marcas discursivas que denotan distancia respecto de lo enunciado por parte del poeta. Pero ante todo son marcas posibles en la escritura, son rastros en el trazo de la letra. La escritura, en este sentido, es "Otro cuerpo" que registra las marcas de la Otredad, tanto como el cuerpo negro registra las marcas de la esclavitud. A su vez, la voz del otro también se marca en la escritura. Estas marcas son visibles en dos aspectos textuales. Uno de ellos, el tipográfico, con el uso de cursivas cada vez que un personaje negro hace uso de la palabra. El otro aspecto afecta los niveles fonético y morfológico. Lo que hace la letra escrita es ficcionalizar la oralidad del otro. Una oralidad "defectuosa", en falta, según la norma culta. Esta recreación de la oralidad por el grupo letrado, culto, pone en evidencia las tensiones ideológicas que operan en la figuración de la esclavitud y del sujeto negro. Esas marcas pueden ser leídas como 
distancias del Otro, y también, como intentos de registrar con una actitud "científica" las variantes del uso de la lengua en los distintos niveles sociales y, de esta forma, contribuir al esbozo del escenario étnico-social de Cuba. Una posición intermedia asumiría este complejo proceso de significaciones como un proceso de negociaciones continuas, en el cual las marcas que el Otro deja en el texto son una metáfora del temor que produce este Otro. Pero también una metáfora de la presencia ineludible de esa Otredad en el espacio social y simbólico.

Mabel Moraña (1997) ha estudiado las complejas relaciones entre la lengua, el poder y la raza en los villancicos de Sor Juana Inés de la Cruz ${ }^{143}$. Nos interesa su trabajo, pues algunas de sus anotaciones sobre un género hispánico oral y popular como lo es el villancico ayudan a pensar cómo el romancero incorpora la voz del Otro. Compartimos su concepción respecto de que la elaboración lingüística tiene una importancia fundamental, ya que opera como signo del enclave social tanto del hablante como del productor cultural que lo construye discursivamente. Según Moraña, en la relación lengua/poder/raza que se expone en el entramado poético de los villancicos pueden distinguirse tres niveles: el primero, tiene que ver con la "lengua corrupta" del dominado y con las posibilidades y el alcance real de la voz del subalterno en contextos coloniales. El segundo, se vincula con el gesto letrado de otorgar la voz al Otro, efectuando una mediación que confirma y reafirma la jerarquización social, cultural y política inherente al sistema colonial. El tercer nivel, se relaciona con la centralidad de las prácticas escriturarias e institucionalizantes de la "ciudad letrada" (1997: 12). Consideramos que estos tres niveles que operan en la representación de la Otredad pueden ser analizados en el romancero cubano del siglo diecinueve, ante todo, porque existe una situación de colonialidad y porque hay un género, el romance, que vehiculiza e integra (al igual que el villancico en Sor Juana) la heterogeneidad cultural americana, en este caso, la cubana. En correspondencia, el romancero presenta un discurso sobre la heterogeneidad que es gestionado, administrado y controlado por la "letra criolla".

Dice Moraña:

143 "Poder, raza y lengua: la construcción étnica del otro en los villancicos de Sor Juana" en Moraña 1997: 7-16. 
Cuando Sor Juana imita el castellano "aportuguesado" del esclavo, los latines erróneos del indígena, las variantes fonéticas y las mezclas lingüísticas en una especie de moderno collage cultural, relativiza la hegemonía de la norma culta privilegio de las élites, configurando una suerte de ficticia koiné novohispana pero desde una posición aún dominante: la del letrado criollo que reivindica el mestizaje cultural como un área específica de su dominio intelectual que en este sentido lo eleva por encima de los sectores marginales pero también del peninsular eurocéntrico y monolingüe (12).

Es claro que el lugar del letrado es un lugar de "mediación y reafirmación" entre las voces que expresan la heterogeneidad. No obstante, la articulación de ese entramado no es idéntica en todos los escritores del romancero. Como hemos visto a partir de los casos de Pobeda y de Milanés, sus mediaciones se vinculan con los intereses políticos, sociales y culturales que conforman su identidad e ideología. Para situar un tercer ejemplo que quiebre el plano de las dicotomías y corrobore esta noción de heterogeneidad del romancero, analizaremos otro romance de Miguel Tourbe Tolón escritor cubano que en 1848 emigra a Estados Unidos y se desempeña como secretario de la Junta Cubana Anexionista de Nueva York ${ }^{144}$. En el capítulo I hicimos referencia a la directa relación entre los anexionistas y el apoyo al sistema de la esclavitud, pues consideraban que Estados Unidos había logrado crecer económicamente beneficiado por las plantaciones de algodón ubicadas al sur y creían que el régimen de la esclavitud era "un mal necesario". En el romance "Un rasgo de Juan Rivero", compuesto por 133 versos, aparece esta idea de la esclavitud como un sistema "natural" de organización de la vida del ingenio. Los primeros setenta versos operan como marco de la historia: presentación del lugar y de los personajes: "uno que viejo parece / otro que en lo treinta frisa/ y una niña de seis años/ que era como un sol de linda" (39-42). El romance relata la conversación entre Juan Rivero, mayoral de la finca y el patrón, Don Pedro. El mayoral le pasa el parte sobre los esclavos, específicamente, le refiere que una de las negras esclavas se ha escapado, luego de que Don Pedro vendiera a su hija. El mayoral le solicita permiso para buscarla con perros, pero el patrón se niega.

\footnotetext{
${ }^{144}$ Ver referencia biográfica que realiza José Lezama Lima en "Los poetas populares", Antología de la poesía cubana. Tomo III. Siglo XIX (II).
} 
Hay varios aspectos a señalar en este romance. El primero, en relación a la niña que aparece en la escena de conversación entre Juan Rivero y Don Pedro:

Chuchú, que tal es el nombre

De la tierna y gentil niña

Dormita inocentemente

Descansando en las rodillas

De su padre, la cabeza

Cubierta con las sortijas

De los dorados cabellos

Que en derredor se esparcían

De su frente blanca y pura

Y sus rosadas mejillas (63-72)

En la descripción que se realiza de este personaje opera la "metáfora de la sangre" que liga pureza a blancura. La imagen de la niña rubia que dormita ("linda como un sol") remite a la figuración de un ángel, imagen que se refuerza con la idea de inocencia. Recurriendo a una expresión metafórica, podríamos decir que en el espacio en el que transcurre la conversación — la sala de la casa - las voces son blancas, pero los temas, negros. De hecho, el planteo que le realiza el mayoral es sobre Petrona, quien ha escapado del ingenio:

-pues señor- iba diciendo

Nuestro mayoral Juan Frías

¿sabe usté como Petrona

Ha vuelto a coger manigua?

-¿cómo así? —exclamó don Pedro

-¿cómo ha de ser? Siendo asina

-replicó el otro con calma:

-yo segura la tenía

Dispués que le di un buen fondo;

Pero se empeño la niña,

Como el señor bien lo sabe, 
En servirle de madrina,

Le quité el grillo y la maza

Al sacarla pa la jila

$\mathrm{Y}$ ¡ojos que te vieron dir!

Se juyó esta mañanita. (73-88)

En los versos transcriptos se aprecia la ficcionalización de la oralidad del mayoral, que se diferencia del registro del narrador y también del registro de don Pedro. Al igual que en otros romances que analizamos, el texto actúa como contenedor de la "diferencia" y aunque en este caso, la diferencia no se grafique mediante la itálica, sí adquiere un valor connotativo que exhibe una oralidad que es blanca, pero defectuosa. De este modo, la diferencia se coloca en el interior del grupo racial y étnico, opera entre el sujeto letrado y el "guajiro"; en este sentido, el letrado actúa como mediador de esas diferencias.

Don Pedro ha vendido a la única hija de Petrona y por eso, la esclava ha intentado suicidarse y, finalmente, se ha fugado. En el relato de este conflicto, ninguna de las voces del romance ofrece una crítica al sistema; al contrario, en boca del mayoral se pone en escena la necesidad de un castigo que logre escarmentar a Petrona. El personaje de Don Pedro es el único que muestra un atisbo de duda sobre su proceder:

-qué extraño- dijo don Pedro

Una negra tan ladina

$\mathrm{Y}$ entre toda la negrada

La mejor que yo tenía.

-pues ya ve el Señor don Pedro

Que dende que el otro día

Se quiso ahorcar de una guásima

Porque usté vendió a su hija

$\mathrm{Y}$ anduvo con alborotos

Y mil facistorerías

Y fue menester virarla 
Pa bajarle la godilla (89-100)

(...)

- ¡es verdad, vendí a María

-dijo el amo en tono triste-

Vendí a su única hija

Aunque ella me suplicaba

Por el amor de la mía (104-108)

El mayoral le dice a don Pedro:

Deje que vuelva a la casa,

Que yo la pondré mansita,

Porque irá de la escalera

Derecho a la enfermería (113-116)

Pero el patrón le ordena que no la busque con perros y frente a esto, Juan Ribero enuncia:

Oyó el mayoral la orden

Con la cara algo mohína

Recogiendo su sombrero

Del suelo, dejó la silla

Pero al salir por la puerta

Allá entre dientes decía:

- ¡Asina hay amos que quieren

Que uno maneje su finca! (126-133)

Este romance expone el dilema moral que genera el sistema de la esclavitud. Si bien en don Pedro hay un mínimo tono de lamento por lo acontecido y cierta piedad, porque pide al mayoral que no busquen a la esclava con perros, en su proceder como amo ha vendido a la hija de la esclava, la trata aparece en este romance como el desencadenante del conflicto. Al mismo tiempo, los cuerpos son mercancía que se comercia y son objetos que se domestican mediante la tortura y el castigo. 
En el caso de José Fornaris su obra más destacada dentro de la vertiente “indianista” es Cantos del Siboney (1855), junto a Ramón Vélez Herrera y Felipe López de Briñas fue director de la Floresta Cubana, Periódico Quincenal de Ciencias, Literatura, Artes, Modas, Teatros, \&. Dedicado al bello sexo (1856) y con Joaquín Lorenzo Luaces dirigió la revista La Piragua (1857) continuadora de la temática siboneyista que introdujo Floresta Cubana ${ }^{145}$. Además, editó la compilación Cuba Poética, colección escogida de las composiciones en verso de los poetas cubanos, desde Zequeira hasta nuestros días $(1861)^{146}$. A su profusa labor como compilador se suma la producción de un romancero que se destaca por presentar una "naturaleza indiana", tal es el caso del romance "Las Palmas". Otros romances elaboran una figuración de la identidad ligada a la metáfora de la familia, tales como "La madrugada en Cuba", "La tarde" y "Managua". Sobre esta particular figuración que subsume las metáforas de la sangre, de la tierra y de la memoria volveremos más adelante.

Con respecto a la configuración del esclavo como Otredad, nos parece oportuno traer a colación el romance de José Fornaris "La flauta triste” (1850), pues en él se le concede voz al esclavo, no obstante es una voz que no presenta marcas de oralidad, pues el romance relata el lamento del esclavo y su voz aparece expresada métricamente en canto compuesto por redondillas:

¡oh qué dolor tan impío

Ponzoña en mi pecho vierte!

¡siempre llamando a la muerte

Bajo un cielo, que no es mío!

En el inicio del romance, el narrador presenta una escena desoladora, en una "estancia vecina":

\footnotetext{
${ }^{145}$ Sobre este tema puede consultarse un interesante artículo de Cira Romano (La Jiribilla 2014) en el cual plantea la continuidad y presencia destacada que La Piragua y Floresta Cubana otorgaron a la temática siboneyista.

${ }^{146}$ Se hallan versiones completas digitales tanto de la Floresta cubana como de Cuba poética.
} 
Todo reposa: dos seres

solo velan en la estancia

es uno el pardo sinsonte

que con dulces trinos canta;

y otro un mísero africano

que al pie de una candelada

va a tocar una flautilla

de rústica cañabrava.

¡qué triste empieza el sinsonte

Sus trinos de madrugada!

¡qué triste el pobre salvaje

Dolientes notas exhala! (5-16)

La comparación entre el sinsonte y el africano coloca a estos "dos seres" en el mismo nivel. Es interesante reparar en los epítetos empleados para presentar al esclavo, pues aluden a su extranjería y a su condición: "mísero africano", "pobre salvaje". Esta doble referencia encierra una connotación distinta a las que presentamos con anterioridad, pues aquí no se hace referencia al negro sino al africano, el énfasis está puesto tanto en el componente racial como en el origen:

¡Qué melancólica gime

Esa música en las palmas!

Las hondas quejas retumban

En la vecina montaña,

Y va extendiéndose el eco

En los aires y en las aguas,

Como el profundo lamento

De las etiópicas razas. (25-32)

Por lo general, en los romances opera una figuración del esclavo solo como cuerpo, en algunos casos, como hemos analizado, es una "masa", un "gran cuerpo", en otros, hay nombres propios "Julián", "Petrona", que identifican a los esclavos, pero eso no los 
convierte en sujetos, más bien, sus nombres permiten registrar la propiedad del amo, son denominaciones de "piezas" comerciables. En este romance, el esclavo no tiene color, aunque es posible establecer también una comparación entre el tono oscuro del sinsonte y la piel del africano, pues nunca se hace referencia a la negritud, solo a su condición y a su origen:

Quedó el esclavo infelice

Soñando con su patria

Soñó ver, lleno de gozo,

Las costas de Senegambia,

$\mathrm{Y}$ al son de los atabales

Volvió a divisar sus playas.

Soñó que su pobre madre

Un beso en la frente le daba

Y que risueño corría

Ya en la fiesta, ya en la caza,

O por la orilla del Níger

En alegre caravana (37-48)

La patria que imagina el esclavo no es Cuba, aquí aparece otra vez la figura del desterrado. Pero el destierro que genera la esclavitud tiene otras connotaciones, pues los esclavos ya eran separados de sus familias en el buque que los transportaba y cuando llegaban a destino, eran otra vez divididos para evitar revueltas (Mintz 1996). Eduardo Grüner (2010), recupera la noción de "middle passage" para explicar, justamente, esa experiencia in-between entre África y Ámerica que sufren los esclavos embarcados, pues están literalmente entre dos continentes, entre dos identidades, (ya no son miembros de su propia cultura, pero aún no han ingresa a la nueva), entre dos formas de las relaciones de producción (la tribal comunitaria y la proto-capitalista de la plantación), entre dos organizaciones (la del parentesco y la del mercado). Para Grüner, “este in-between es el testimonio de la feroz violencia proveniente de la esclavización" (439). En consecuencia, podemos sugerir que la patria del esclavo es una patria atomizada que se vuelve posible solo en el recuerdo y la añoranza. También en esa 
configuración podemos ver las metáforas de la sangre, en la figura de la madre, y de la tierra, en la naturaleza africana condensada en algunas referencias que adquieren valor simbólico, como "la orilla del Níger".

Sin embargo, en este romance, ni el origen ni la raza aparecen como justificativos para la esclavitud. Otro aspecto que se destaca en esta composición de José Fornaris es la invocación religiosa, pues cuando el mayoral castiga al negro que ha dejado de tocar la flauta, su hija, Magdalena, intercede para que cesen los latigazos:

Magdalena, prosternada

Delante de un crucifijo

Así convulsiva exclama:

-¡Dios de los orbes, Dios mío

Apiádate de esta raza:

Extiende tu mano, borra

El sello vil que la marca,

Y hazla sentar al banquete

De la gran familia humana! (76-84)

Estos versos finales del romance instalan una figuración recurrente en el romancero de José Fornaris: la metáfora de familia. En este caso, opera para explicar la extranjería de unos seres que por la esclavitud han quedado fuera "del banquete" de la humanidad, pero en otros romances, la metáfora sirve para proyectar un ideario patriótico que propone una estrecha relación entre el hombre y la tierra. En el romance "La madrugada en Cuba" (1868) una de las figuraciones de la patria cubana es la familia:

Ni hay duda que es este cielo

Aún más bello que el de Italia

Pero si fuese tan triste

Como lo es de la Bretaña

Lo quisiera por ser mío,

Por ser el de mis hermanas,

Por ser el mismo que un tiempo

Con mi madre contemplaba (77-84) 


\section{$(\ldots)$}

Bajo este cielo he crecido

En mis selvas y cañadas

$\mathrm{Y}$ va en mi sangre, en mis venas

Y clavado en mis entrañas.

En fin sabed que lo adoro

Con todo el fuego del alma

Porque no hay cielo en el mundo

Como el cielo de la patria (93-100)

Esta metáfora que sirve para explicar el vínculo entre el sujeto y la tierra también aparece en otros romances, por ejemplo, "Managua", una composición de 108 versos en la cual se presenta a una familia de la campiña cubana que vive en "perfecta" armonía con la naturaleza. En este romance no hay tensiones, y los sujetos entablan una relación íntima con la tierra, la fauna y la flora:

En ese hogar pintoresco

De la campiña cubana

Feliz vive una familia

Noble, generosa, franca.

Allí Margarita impera

Por afable y moderada

Allí Luisa, una trigueña

Tan hermosa como casta

Que forja un amor celesta

En su primera mañana.

Allí Alberto que es el dueño

De esa mansión ignorada;

Y del poblano y del guajiro

En él los tipos encarna.

Sabe el idioma del campo

Cual la lengua castellana

Como maneja el machete 
Es afable con las damas

$Y$ al par que de las cosechas

De los Garcilaso habla.

¡Salud, oh, cara familia

De los montes de Managua!

¡Salud, morada risueña

De los campos de mi patria! (31-56)

La familia liga sangre, memoria y tierra y se convierte en una supra-metáfora de la patria cubana. En este sentido, como núcleo originario de la socialización, la familia provee los ideologemas básicos que se trasladan a la figuración de la nación como extensión del vínculo en el que se conjugan genealogía, tradición, asociación natural y ayuda mutua (Moraña 1997: 98). Aunque José Fornaris ofrece el ejemplo más claro dentro del romancero de este uso metafórico, sabemos que su formulación se relaciona con la retórica de emancipación de los letrados de la Ilustración y los libertadores, y, en el caso cubano, quizá sea José Martí la figura que mejor utiliza y cristaliza en su discurso patriótico la metáfora de la familia. Julio Ramos (1989) ha analizado en "Nuestra América" el funcionamiento los dispositivos metafóricos que en el discurso martiano articulan las relaciones entre la lengua materna y el poder en torno a la construcción de la nación.

Del romancero de Fornaris también nos interesa reparar en la construcción del yo poeta, pues difiere de algunos otros escritores, tal vez se acerca en su intención de trovador a Pobeda. Por ejemplo, en el romance que ya analizamos, "Managua", hay una intención explícita del poeta de ser el intérprete del sentir del pueblo y de alguna manera, anhela que sus versos circulen en boca de los guajiros al son del tiple:

Cantará mi ardiente Musa

En idilios y baladas,

De estos cerros y collados

Los misterios y las galas.

$\mathrm{Y}$ en pago de mis cantares

Oír mis versos me basta 
Al son del rústico tiple

De los hijos de Managua. (101-108)

Con respecto a esta figuración del poeta, advertimos en el romancero de Fornaris, el reconocimiento a cierta tradición poética, gesto que, por un lado, hace visible un ámbito letrado singular y, por otro, esa demarcación y la referencia explícita a ciertos escritores, permite trazar un itinerario de producción y de recepción de las lecturas del período. En el romance "La tarde" (1867) señalamos estos versos:

¡Cómo no amarla el que nace

Aquí bajo las palmeras,

En donde en su frente agosto

Un caso de llamas muestra,

Y diciembre se corona

Con rosas de primavera!

La amó Milanés, el bardo

De primorosas leyendas,

La amó Tolón, la amó Delio,

La adoró el divino Heredia (55-64)

La generación de poetas de José Fornaris sería la "tercera" en acercarse al romancero como género para vehiculizar el sentir patrio. La primera sería, sin dudas, la de Francisco Poveda, Domingo del Monte y Ramón Vélez Herrera. Un grupo de poetas más jóvenes como José Jacinto Milanés y Miguel Teurbe Tolón integrarían un segundo círculo generacional, que se completaría, años más tarde, con José Fornaris y Joaquín Lorenzo Luaces, también citados en este capítulo.

\subsection{La sangre ausente: figuraciones de lo indígena}

Si en Cuba la identidad patriótica se elabora literariamente en un juego de contracaras o binomios que articulan una retórica de la Otredad que se condensa en el componente racial y que opone lo criollo-blanco a lo extranjero-negro, es necesario advertir que en el romancero decimonónico también se alude al rastro indígena, en tono evocativo y con una valoración positiva. En este sentido, en varios romances se aprecia la mención 
de los siboneyes como una vertiente formadora y primigenia de la cubanidad. Es decir, se proyecta en los romances la idea de que en las raíces de la nacionalidad cubana hay un grupo indígena que ha sido arrasado, pero que es necesario reconocer como aporte sustancial en la constitución de la identidad de la patria.

Como ya hemos mencionado, José Fornaris inicia alrededor de 1850 uno de los movimientos más importantes de la literatura cubana, el "siboneyismo". Al respecto, Virgilio López Lemus señala que "Los cantos del Siboney" (1855) de José Fornaris fue un libro de mucha trascendencia en la historia de la poesía cubana, "suerte de bestseller con cinco ediciones sucesivas, su éxito marcó el primer hito de corte multitudinario de la poesía insular" (1999: 77).

Según Jorge Camacho (2007) “en la superficie, el siboneyismo fue un intento de sacar del olvido el sufrimiento de la aborigen raza pero en el fondo significó un proyecto mucho más ambicioso, el de repensar la historia insular desde una perspectiva propia, y alentar los ideales independentistas de muchos cubanos” (2). Esta visión es compartida por otros críticos (Feijoo 1977; López Lemus 1999; Vitier 2002), pero Camacho propone una tesitura novedosa al considerar que el siboneyismo significó "la extensión de un proyecto filológico y etnográfico, que habiendo comenzado en Europa en los siglos precedentes se extendió a América a principios del XIX, dándoles a los siboneyistas el nuevo lenguaje a través del cual expresar sus sentimientos y cuestionar lo heredado de España” (2007: 3). Advierte Camacho que los estudios filológicos del siglo diecinueve son una continuación de los debates lingüísticos desarrollados en Europa, algunos de los cuales tenían que ver con la estructura de la lengua de los indígenas de América, por ejemplo, los estudios de Charles Brosses (1709-1777). Al respecto, como mencionamos en el desarrollo de esta tesis, en las primeras décadas del siglo diecinueve, los letrados criollos ponen de manifiesto en una pluralidad de discursos, la intención de configurar una identidad diferenciada de la metrópoli. Este anhelo los conduce a la búsqueda de las peculiaridades nacionales, al mismo tiempo que el paradigma imperante de las ciencias naturales ofrece los métodos para esta búsqueda. En consecuencia, los letrados criollos emprenden la labor de estudiar el lenguaje, y aparecen como resultado de este esfuerzo varias obras fundantes, por ejemplo, la Gramática (1847) de Andrés Bello y numerosos diccionarios de 
regionalismos que recogen los nuevos vocablos propios de cada país. Tal es el caso del diccionario que aparece en Cuba, producto de la labor del geógrafo y lingüista Esteban Pichardo y Tapia, el Diccionario provincial casi razonado de frazes y vozes cubanas (1836). Sin embargo, Jorge Camacho indica en su artículo que Pichardo no fue el único en investigar la lengua "siboney" en Cuba, pues en 1842 Antonio Bachiller y Morales publica en el Faro Industrial de la Habana, otro escrito sobre el mismo tema, "Entretenimientos históricos sobre la isla de Cuba. El idioma primitivo" y en este ensayo, luego reproducido en su Cuba Primitiva (1883), analiza las semejanzas de la lengua "siboney" y las otras del continente sudamericano, en especial, los de la cuenca del Caribe, tomando como referencia el libro del también geógrafo Agustín Codazzi (1793-1859), Resumen de la Geografía de Venezuela (1841) (2007: 4).

En el caso de Fornaris, el trabajo con la lengua se advierte en la recuperación de vocablos indígenas: introdujo en sus poemas nombres de ríos, personajes históricos y nombres de la flora y la fauna de Cuba que registraban geográficamente una topografía prehistórica, un mapa de lugares aborígenes en todo el país. Fueron tantos los vocablos que incorpora que al final de su libro incluyó un glosario de palabras para que los poemas se entendieran. Según Jorge Camacho, a partir de los estudios lingüísticos de Antonio Bachiller Morales y, sobre todo, de Esteban Pichardo, se entiende por qué José Fornaris llega a cuestionar la forma en que los cronistas de Indias y los historiadores anteriores habían escrito muchos nombres aborígenes y decide alterar la ortografía de muchas palabras empezando por la que daba título a su poemario. Cita Camacho la explicación que ofrece José Fornaris:

Sibonei: así llamaban los indios en los primeros tiempos a los naturales de la isla de Cuba. Algunos escriben Cibonei pero nosotros nos adherimos a la opinión del ilustrado americano D. Esteban Pichardo: según este escritor ecsisten graves razones para creer que los naturales no pronunciasen la C. Así lo ha observado este Señor en Jiguaní, Canei \& c.; en cuyos puntos se conserva algún rezago de la raza india. Además dice que los cubanos en la presente época no pronunciamos la $\mathrm{C}$, i que esto seguramente depende del influjo de la tradición. Por estas mismas razones, escribimos seiba, Semí \& c. (2007: 5). 
En el apartado anterior señalábamos que José Fornaris reconoce cierta "legado" o tradición en la que inscribe su obra, pero como ejemplo de una superposición de lugares de la enunciación, advertimos en el romance ya citado, "La madrugada en Cuba”, una figuración diferente del poeta que se presenta del siguiente modo:

Yo también, cantor indiano,

En estas noches tan claras

Busco a luz de la luna

Allá por la madrugada (1-4)

Nos interesa esta autofiguración del poeta como "cantor indiano", pues replica en dos dimensiones. Por un lado, la idea de canto vuelve a ser una marca constante de todo el romancero cubano. Por otro lado, lo "indiano" remite a esa particular visión que Fornaris pretende recrear en su poesía y se relaciona con el habitante primitivo de la isla, el indio Siboney. Mientras que en otros romances aparecía con más claridad la figuración del criollo, aquí es trastocada por la del indiano que detenta un conocimiento más "antiguo" de la isla. Esta forma de acceder a la naturaleza se aprecia en el romance "Las Palmas", en el cual la voz del poeta indiano adquiere autoridad por ser testigo, pero ese "ver" no es solo sensitivo, sino que funda un paisaje, una imagen de la naturaleza cubana:

Yo vi la frondosa ceiba, En las extensas sabanas, Vi los jobos y los cedros En medio de las montañas, Vi las soberbias caobas Como reinas soberanas

Vi a la margen del arroyo

Los mangles y las majaguas. (1-8)

Esa naturaleza aborigen recreada por el poeta adquiere un rasgo pictórico que se construye mediante la integración de los elementos en una composición. De este modo, el reordenamiento que realiza el poeta modifica la naturaleza contemplada en paisaje: 
Pero son aún más hermosas

Las aborígenes palmas

Que se mecen en los campos

De mi Cuba idolatrada.

Las palmas, jay!, deliciosas

De mis pintorescas playas.

(...)

Las palmas ¡ay! que semejan

Por el céfiro agitadas

Los fantásticos plumeros

De indígenas caravanas (15-26)

Si bien lo aborigen se presenta en el nivel temático, su referencialidad queda expuesta en un plano superficial, pues no hay una recuperación profunda y problematizada del elemento autóctono, muestra de ello son las menciones al "céfiro" y a "lo fantástico" que anclan el romance en una retórica oscilante entre lo neoclásico y lo romántico. Un uso similar de la figura del indígena es el que realiza Gabriel Plácido de la Concepción Valdés en su romance sobre Moctezuma titulado "Jicontecal” (1856). En relación a este, debemos mencionar que en la época circulaba una novela titulada Xicotencatl, escrita en 1826 y cuya autoría era atribuida al cubano José María Heredia.

Esta misma mirada pictórica sobre el componente indígena aparece en el romance "El combate de las piraguas" de Ramón Vélez Herrera, una composición de 196 versos en la cual el tema central es el combate en el mar entre dos tribus enemigas, las de Bahamas y las de Jagua. El romance tiene mucha acción acorde al tema del enfrentamiento belicoso que narra. No hay pasajes descriptivos extensos y las caracterizaciones de los guerreros, de los jefes caciques se realiza mediante epítetos e hipérboles que magnifican a los contrincantes. La mirada romántica sobre los grupos indígenas se aprecia en la construcción idealizada de los caciques, presentados como héroes de la patria: 
Oye el cacique de Jagua

Al fiero Ornoya confía

La salvación de la patria (57-60)

¡Ornoya! El fiero guerrero

Flor de los héroes de Jagua,

Cuyo brazo no vencido

Era el cedro en la montaña,

Y cuya voz excedía

Al trueno que ronco brama,

En rapidez semejaba,

Da la señal, y sangrientos

Sus guerreros avanzaban,

Y empeñan la recia lid

Tiñen de sangre las aguas (71-82)

Finalmente, las características heroicas de Ornoya son las que definen el triunfo de su tribu:

Y furioso el bravo Ornoya,

Rompe, desordena, mata,

Filas enteras derriba,

$\mathrm{Y}$ de piragua en piragua,

Como el rayo en la tormenta

Atropella, desbarata,

Y en el montón de cadáveres

Su sombra se dibujaba

Como el ángel de la muerte

Que el universo amenaza (173-182)

La construcción del rival como un enemigo digno enaltece aún más las condiciones viriles y guerreras de las tribus de Jagua:

Son los guerreros feroces 
De las vecinas Lucayas

Tiñen el rostro severo

Pintas negras y encarnadas

Y a la merced de los vientos

Las rojas plumas flotaban.

Un cacique los dirige

Tan experto en las batallas

Que no hay islote en el golfo

Que no cante sus hazañas (15-24)

También es interesante notar que en este romance la naturaleza se condensa en el mar como escenario de la lucha. En este sentido, el campo semántico de lo marítimo recrea otra naturaleza cubana, la plenamente insular ${ }^{147}$ :

Todo es vida y movimiento

Hierve la gente en las playas,

Resuenan los caracoles,

Cúbrese el mar de piraguas (61-64)

El mar como escenario de la guerra con su geografía y su fauna también interviene en la lid, a diferencia de otras configuraciones, en este romance se presenta una "naturaleza marítima bélica”. Al respecto, Rafael Rojas (2009) sostiene que en la literatura cubana del siglo diecinueve hay toda una tradición que presenta el mar como "lo negativo", "lo sombrío", "lo diabólico". Sin embargo, este imaginario se revierte en el siglo veinte a partir de la literatura del exilio en la cual el mar desplaza a la tierra como centro gravitacional de los discursos. También señala que las figuraciones de la costa, como espacio fronterizo entre el mar y la tierra, han sido poco abordadas.

Este romance resulta revelador en el imaginario bélico marítimo y costero:

${ }^{147}$ El tópico del mar es abordado de manera fundacional en la poesía cubana por José María Heredia en dos poemas: "Calma en el mar" (1832) y "Al océano" (1836). También se alude a la figura del mar en los poemas de "Al partir" (1836) de Gertrudis Gómez de Avellaneda "Al partir" y, "El mar", de José Jacinto Milanés (1835). 
El mar sus ondas levanta,

Y se amontonan cayendo

Piedras, troncos, leños, mazas.

A los golpes se desploma

Una entreabierta piragua,

$\mathrm{Y}$ en las rocas puntiagudas

Se oyen estrellar las tablas. (112-118)

Los guerreros semivivos

Arroja el mar en las playas

Y los fúnebres clamores

Lleva el viento en sus alas.

Los tiburones roqueros,

En las olas aleteaban,

Y a los héroes insepultos

Con los dientes despedazan (131-138)

Pero, al mismo tiempo, es un mar diferente del que se presenta en otros romances, pues este es un mar "habitado" y la constelación de islas y sus lazos posibilita la emergencia del Caribe como un espacio con una identidad y una tradición singular: "que no hay islote en el golfo / que no cante sus hazañas". Por otra parte, cierta idea de lo sobrenatural surge como elemento de identificación de los indígenas.

Y a lo lejos parecían

Las infernales fantasmas

Que en las tartáreas regiones

Entre las tinieblas vagan (45-49)

Este rasgo se vincula con lo mitológico y con la atemporalidad, dos aspectos que, entendemos, sirven para fijar en el imaginario colectivo la noción de una "raza" primigenia y original en la cual hundiría sus raíces la cubanidad. Esa patria defendida es una patria anterior, pero el rasgo mítico torna recuperable esa proeza bélica, y el romancero reactualiza y resignifica el componente étnico indígena como un sustrato 
altamente valorable. El pueblo originario de la isla, los Siboney, fue diezmado con la conquista; no obstante, si nos remitimos a la metáfora de la sangre bajo la cual consideramos las figuraciones de los sujetos en el romancero cubano, podríamos sostener que lo aborigen alude a la metáfora de la "sangre ausente", pero el poeta recupera esa "sangre derramada" y bajo la metáfora de la memoria, reescribe la historia y sitúa como primeros héroes de la patria a los indígenas de la isla. La "sangre ausente" es sangre constante en el romance, derramada por la patria y por eso su pérdida no se lamenta. Es la sangre de los héroes:

Da la señal, y sangrientos

Sus guerreros avanzaban (79-80)

En el cráneo del vencido

Las agudas uñas clavan

$\mathrm{Y}$ en las órbitas vacías

Los sangrientos ojos saltan (123-126)

Lago de sangre es el fondo

De cada hundida piragua (139-140)

En cuya frente tostada

Azules y blancas plumas

Tintas en sangre flotaban (154-157)

La configuración del indígena como el primer héroe que tuvo la patria cubana se torna explícita cuando en el romance, aparece su voz:

Pero al ver que el enemigo

Doble irritado su audacia

Con acento varonil

A su hueste electrizaba:

“compañeros, la victoria

Corona nuestra esperanza 
Combatamos, y seguidme,

Que el que expire en la batalla

A la noche del sepulcro

No bajará sin venganza" (93-102)

Esta voz del guerrero que alienta a su hueste y que convoca a la batalla reactualiza en el romance el tema de la independencia cubana, pues esa voz antigua se vuelve una voz presente que reclama una actitud de defensa de la patria y, si bien Ramón Vélez Herrera publica sus romances en 1856, cuando aún falta más de una década para que se inicien las guerras de independencia (1868-1878 "Guerra de los Diez Años o Guerra Grande), el romancero indigenista que produce instala solapadamente el tema de un posible enfrentamiento con la metrópoli.

El proceso de ficcionalización de la voz del indígena difiere de la voz otorgada al negro, puesto que éste último no es considerado como sujeto de la patria, su posición es menos que subalternidad, pues el lugar de esclavo lo sitúa como objeto, lo deshumaniza, lo animaliza, por lo tanto, la voz que el letrado le otorga es una voz controlada y que reafirma ese no-lugar en el proyecto nacional. En este sentido, la negritud significa la Otredad por antonomasia.

No obstante, este intento de los criollos letrados en el proceso de configuración nacional por ocultar, silenciar o bien, controlar la peligrosa heterogeneidad está, como señala Julio Ramos, "desde adentro minado por el estímulo de su propia negación, por la huella de esa heterogeneidad que no cesa de reemerger, sobre todo en la ficción, como un resto inapropiable, aunque constitutivo de la nación a lo largo de todo el proceso de su inconcluso devenir" (1996: 25).

En cambio, la voz del indígena es doblemente ficcionalizada, porque es una voz cuyo registro tonal se desconoce, no existe en el presente de enunciación, es una voz perdida, que opera en la configuración identitaria de la cubanidad que promueven los letrados criollos como una resonancia, como un "eco" que llega hasta el presente:

El caique de Bahama

En el altar se arrodilla, Jura el guerrero venganza 
Y su belicosa gente

Se encamina a nuestras playas.

Pueblan con ecos sonoros

Los aires y las montañas (4-9)

Es decir, no se ficcionaliza la condición étnica-cultural de la lengua de los indígenas, sino una actitud: la voz pone en escena un pronunciamiento guerrero que enfatiza el carácter heroico del indígena. En el romance de Vélez Herrera el bravo indígena habla como un "prócer", dispuesto a morir por su patria, y esto impregna su discurso de una atmósfera atemporal y mitológica. Las palabras que pronuncia Ornoya no son las de un cacique siboney sino las de un héroe de la patria:

\author{
-Avancemos, compañeros, \\ El que espera, nada aguarda, \\ La prudencia hace al cobarde \\ El héroe fía en la audacia. (33-36)
}

Si la voz del negro en el romancero es una voz silenciada, reprimida, mutilada, castigada o articulada bajo una retórica criolla y blanca que la controla y negocia su visibilidad, por el contrario, la voz del indígena es una voz perdida que el romancero reinventa, re-ficcionaliza, reactualiza. Estas operaciones discursivas que modulan imaginarios identitarios complejos deben ponerse en relación con las contradictorias posiciones que los letrados criollos cubanos asumen en un contexto político, cultural, social y económico signado por el cambio constante. Las superposiciones, las omisiones, las síntesis, las dislocaciones que se advierten en el imaginario patriótico que elaboran los letrados funcionan como significantes de la fisura inevitable que se genera cuando las figuraciones de la patria entran en tensión con los proyectos políticos que la Ilustración cubana gesta en este periodo. 


\section{Conclusiones}

Hemos llegado al final del recorrido propuesto. En esta instancia de cierre, cuando ya ha sido transitado el sinuoso camino de la investigación, advertimos que, de manera paradójica, arriesgar conclusiones se torna una tarea compleja e intimidante. Por esta razón, nuestra escritura observa cierta - y parcial - desobediencia al título que nos convoca en este apartado. No obstante, como observa con atino Eduardo Grüner:

Un libro debe terminar en algún momento. "Terminar" — aquí como en tantos otros lados — quiere decir simplemente, tomar la decisión de poner un punto final (como decía Borges, se publica para no seguir corrigiendo) (2002: 419).

Compartimos este sentido y consideramos que estas últimas páginas tienen por objeto, no la proclamación de certezas sino la enunciación de preguntas, la advertencia de vacíos, pues si hay algo que caracteriza a una tesis, aún a riesgo de herir el narcisismo de quien la escribe, es su parcialidad. Pero no consideramos esto como una carencia sino como la oportunidad de continuar con el trabajo desarrollado. Se trata, como bien señala Grüner, "de abrir ventanas, puertas, aunque fuera rendijas, hacia nuevos territorios que nuestro texto solo ha mirado de reojo" (419). Tomamos su indicación como una guía para la elaboración de este apartado y proponemos, en correspondencia, la organización de las conclusiones en dos partes. En la primera, quisiéramos revisar tanto el itinerario teórico desarrollado como la construcción del corpus, con la intención de reflexionar sobre la configuración del objeto de estudio e hipotetizar, a partir del itinerario propuesto, posibles desvíos que en el trayecto diagramado no han sido considerados. La segunda parte se organiza bajo dos subtítulos que, a nuestro parecer, nos posibilitan la recuperación de los núcleos problemáticos centrales de esta tesis. Por último, compartimos algunas proyecciones del tema hacia el siglo veinte.

En razón de lo expuesto, y parafraseando la cita inicial, estas conclusiones ponen en evidencia un punto final que, semánticamente, debería ser leído como un punto seguido, un punto y aparte o unos insinuantes puntos suspensivos. 


\section{Primera parte}

\subsection{Consideraciones finales sobre la teoría}

En el capítulo inicial de esta tesis, propusimos analizar el rol de los letrados en la configuración de la patria cubana en el siglo diecinueve. La descripción del título era contenedora, al mismo tiempo, de los problemas teóricos centrales que implica su desarrollo. A nuestro parecer, son tres los elementos que articulan el sentido de este capítulo de presentación: los letrados, la patria y el siglo diecinueve. Si bien, las definiciones asumidas en el marco teórico que se explicita en ese acápite permiten pensar las relaciones entre estas entidades, lo cierto es que cada una por separado convoca muchas otras teorizaciones que entran en discusión, se oponen y superponen y generan que, por debajo de cada uno de estos términos, opere un complejo sustrato disciplinar causante del espesor teórico y simbólico que los define. Como forma de resolver el escollo intelectual que supone poner en relación tales entidades, hemos optado por elegir algunas categorías que nos permitieron atravesar e intervenir sus campos de referencia, estas son: Modernidad, identidad, Americanismo y Criollismo. Desde el desarrollo propuesto, estas categorías nos han sido útiles para problematizar las múltiples definiciones que entran en juego y para visibilizar la densidad teórica ya aludida aunque se hayan dejado de lado otras teorías o perspectivas que - aunque sumaran enfoques - no nos parecieron funcionales para intervenir en el corpus.

En este sentido, el capítulo I inaugura lo que podríamos denominar "el tono de la tesis", es decir, la tendencia a establecer constelaciones teóricas particulares que dejan afuera otros enfoques. En nuestro caso particular, para pensar el siglo diecinueve hemos recuperado la perspectiva de análisis que desarrollaron Guerra, Quijada, y Lempérière, entre otros, quienes proponen abordar la Modernidad como un proceso recíproco que tiene lugar a ambos lados del Atlántico. Asimismo, partimos de considerar el contexto cubano decimonónico como un entramado singular de relaciones intra e inter culturales; como un espacio marcado por la vertiginosidad del cambio, como una isla "no aislada" sino en continua extensión hacia el continente americano y hacia Europa y África. Este enfoque trans-nacional para abordar precisamente la configuración de lo nacional puede ser objeto de crítica pues muchos de los estudiosos 
que hemos citado realizan un abordaje diferente, tal es el caso de Cintio Vitier o de Rafael Rojas, dos autores muy citados en nuestro trabajo, que, bajo diferentes metodologías y teorizaciones, proponen una mirada "nacional" de lo cubano.

Otros críticos, en cambio, como François-Xavier Guerra y Víctor Goldgel invitan a posicionarse en un enfoque más amplio que permite poner en relación y discusión procesos culturales llevados a cabo en distintos puntos de Latinoamérica. Sus trabajos han sido valiosas guías para pensar nuestro objeto de estudio. No obstante, optar por una perspectiva teórica que nos lleve fuera de Cuba encierra la posibilidad de caer en dos errores, uno es la superficialidad, es decir, tomar algún elemento de una conceptualización mucho mayor $\mathrm{y}$, en ese recorte, vaciar de contenido la teoría y tornarla mera referencia. El otro error podríamos denominarlo "de aplicabilidad", pues se toman perspectivas desarrolladas para otros objetos, otros sujetos y otros espacios, con lo cual se corre el riesgo de incurrir en anacronismos o inadecuaciones teóricas. No obstante, consideramos que la perspectiva teórico-metodológica que hemos asumido es la que nos permite una aproximación crítica al corpus de estudio lo suficientemente flexible como para contemplar un abanico de intereses bastante amplio que se despliega en la exploración de las figuraciones de la patria que analizamos en el romancero.

En consecuencia, en la propuesta que realizamos el Americanismo y el Criollismo fueron pensados como un "par" que bajo sutiles, pero identificables diferencias nos permitía organizar el complejo espacio de enunciación de los letrados en el siglo diecinueve y, al mismo tiempo, problematizar ese lugar de la palabra a partir de la emergencia de una identidad colectiva que se advertía distinta de la situada en la metrópoli. En este sentido, estas dos configuraciones de las expresiones identitarias lo criollo y lo americano - posibilitaban discursivamente el gesto inaugural del "sentir patrio". Pero, mientras que el Criollismo alude con claridad a las manifestaciones de distinta índole llevadas a cabo por un sector reconocible de la sociedad: los patricios criollos de la Ilustración cubana relacionados a ciertas facciones liberales; sostener cierta idea de Americanismo en el período de corte de nuestra investigación es más arriesgado (esto no es así sobre finales del diecinueve, cuando la figura de José Martí instala un imaginario americano fundacional con el paradigmático ensayo "Nuestra 
América") porque la mayor parte de los estudios plantean un Americanismo continental pronunciado desde el continente. Lo caribeño se concibe, entonces, como una manifestación identitaria que en simultáneo atraviesa, marca y define lo criollo y lo americano. Si bien las islas del Caribe son ignoradas como espacio de reflexión en la mayoría de los ensayos sobre el Americanismo que se producen en el período, como si el Caribe no perteneciera a América o fuera un espacio Otro, entendemos que desde la propuesta teórica realizada, ejercemos una vuelta de tuerca sobre el tema, al recuperar una concepción de la Modernidad en tanto experiencia euroamericana profundamente transformadora y articuladora de espacios muy distintos (como el Cono Sur de América y el Caribe) que entran en relación a partir de esa coincidencia epocal.

Por otro lado, la presencia e influencia de Domingo del Monte en el ámbito cultural de la isla (que se extiende desde 1830 hasta su muerte, en 1853) nos ha permitido pensar la hipótesis de un embrionario "americanismo cubano", es decir, la impronta cubana y caribeña de una "expresión americana" que se desarrollará con creces durante todo el siglo veinte.

Si en el capítulo I expusimos los lineamientos teóricos que nos permiten problematizar aspectos tales como la configuración de la patria y las características de los grupos letrados decimonónicos; en el capítulo II, completamos el panorama cultural a partir de indagar en las redes entre letrados, la circulación de los textos y las prácticas de lectura que se llevan a cabo en los espacios de sociabilidad que se gestan a partir de 1830.

En el capítulo III se ponen en tensión las estéticas que organizan la esfera de la producción letrada y literaria en el periodo de corte de nuestra investigación. Al respecto, las alusiones al Neoclasicismo y al Romanticismo operan no solo como marcos de referencia e interpretación del corpus analizado sino como posiciones de enunciación muy complejas y, en ocasiones, contradictorias que asumen los letrados en la primera mitad del siglo diecinueve, en un ámbito cultural que comienza a manifestar una proto-organización y secularización. Es decir, por un lado, estas corrientes imponen "la moda" en la escritura (la elección de ciertos géneros, el predominio de algunos tópicos, la recreación de temas particulares, la lectura de determinados autores) y, por otra parte, estas estéticas generan movimientos en el interior del espacio 
cultural y suscitan ente los intelectuales polémicas que, como suele ocurrir, expresan mucho más que el debate que instalan. En este sentido, el pertenecer o alejarse de estas formas otorga al escritor una posición singular en el campo de las letras y contribuye a la configuración de una identidad literaria.

Por último, en el capítulo IV analizamos un corpus de romances a partir de considerar las relaciones temáticas y genéricas con otras tradiciones literarias, como la décima y el romancero español. Al mismo tiempo, nos resultaron muy funcionales para abordar este corpus aquellas teorizaciones que realizaron críticos como Julio Ramos, Mabel Moraña, Josefina Ludmer, Rafael Rojas, entre otros, sobre distintas textualidades producidas en el mismo período en diferentes regiones de América Latina.

En consecuencia, organizamos esta investigación de modo tal de intercalar los capítulos que presentan más contenido teórico-conceptual (I y III) con aquellos que se constituyen en torno al corpus (II y IV).

\subsection{Consideraciones finales sobre el corpus}

Como señalamos de manera preliminar en la introducción de esta tesis, lo que distingue a la producción literaria conocida como el "movimiento de los romances cubanos" es su desconocimiento. Una aproximación crítica a este conjunto olvidado y poco estudiado fue un desafío, pues la indagación que propusimos considera contemplar en este corpus las figuraciones de la patria y, como hemos explicado en el punto anterior, ese abordaje implica tener presente una multiplicidad de elementos que entran en tensión: la identidad colectiva, la condición territorial y la temporalidad, las representaciones subjetivas de los actores involucrados y el proceso de recepción, entre otros.

Asimismo, al abordar un romancero es necesario considerar, por un lado, las relaciones con la tradición romancística dentro y fuera de la isla, y por otro, contemplar los vínculos con otras tradiciones literarias, como el caso de la décima, cuya impronta en el campo de las letras cubanas es mayúscula. Además, en este cruce de tradiciones, es preciso poner en diálogo las estéticas contenedoras de las prácticas escriturarias en el periodo de corte, pues las corrientes en vigencia son signo de debates sobre la lengua 
y la literatura, y en un sentido más amplio, también operan como marcos de interpretación de las concepciones de mundo que han sido plasmadas en distintos discursos, entre ellos, el literario.

Ahora bien, el corpus de esta tesis está compuesto, además, por otras textualidades no ficcionales: cartas y artículos de corte ensayístico. Es decir que, al grupo de romances que funciona como corpus central, hemos sumado otros tipos discursivos para indagar en su conjunto temáticas relacionadas a la configuración de la patria que realizan los letrados criollos.

Son varios los puntos sobre los cuales podríamos reflexionar en esta instancia. En primer lugar, como no se trata de una tesis de autor, la elaboración del corpus fue una tarea compleja, que reposa en decisiones sometidas a una permanente revisión en la medida en que la constitución del corpus y sus variaciones también modifican las hipótesis formuladas. En este punto, las "ventanas se abren", sostenemos que el itinerario de lectura y análisis que propusimos es una posibilidad entre muchas, pues es cierto que se podrían haber incluido otros autores o bien, centrarse únicamente en un par. Pero pensamos en un corpus que nos permitiera elaborar una composición no necesariamente armoniosa de las imágenes de la patria que se proyectan en un género que arrastra una tradición antigua y singular. Por esta razón, escogimos un conjunto de romances lo suficientemente amplio y diverso que nos permitiera exponer las similitudes, las diferencias y las superposiciones de los imaginarios que entran en tensión, pero que, al mismo tiempo, fuese lo razonablemente acotado para que su análisis fuera posible en los márgenes de una tesis. Es por ello que tal configuración del corpus es entendida como "una" entre otras tantas posibilidades de realización. Es evidente, entonces, que cada uno de esos autores y textos no escogidos ofrecen otras instancias de investigación. Al respecto, solo mencionamos dos autores cuyas obras no han sido incorporadas en esta tesis y que podrían ser objeto de reflexión y análisis en una instancia futura. Se trata de los escritores José María Heredia (1803-1839) y Gabriel Plácido de la Concepción Valdés (1809-1844). Si bien son autores que la crítica ha abordado, en especial al primero por ser el ícono del Romanticismo cubano, hipotetizamos que una triangulación entre ellos y Domingo del Monte podría ser una aproximación novedosa a sus respectivas producciones, pues cada uno asumió distintas 
posiciones frente al hecho literario y tuvieron diferentes accionares frente al mismo contexto $^{148}$. Asimismo, sería valioso indagar respecto de cómo se configuran en el discurso literario estas diferencias.

En segundo lugar, si bien no propusimos un corpus de autor sí establecemos una notable jerarquía entre los autores trabajados que se corresponde con el lugar central o la "paternidad" que Domingo del Monte tiene con respecto al movimiento de los romances cubanos. De este modo, situamos como punto referencial la obra de este autor para entender la posición que asumen otros escritores en el escenario cultural decimonónico. Es por ello que trasladamos a la organización y jerarquización de las textualidades analizadas (romances, cartas, artículos) el posicionamiento protagónico que ejerció Del Monte en el ámbito de las letras. Aquí ponemos en evidencia un tercer aspecto a considerar, esta función de faro que su figura cumple encierra una actitud paradójica, pues, como señala Fina García Marruz en los Estudios Delmontinos, "este hombre apenas escribe"; mientras que alrededor suyo genera una enorme actividad literaria, su producción es muy escasa. Del Monte tiene el don para influir de manera sutil, "a su lado, son los otros los que hablan" (2008: 7).

Esta observación que realiza la escritora cubana parece un comentario más dentro de los ensayos que componen su estudio, sin embargo, se torna para nosotros un señalamiento muy importante, pues cuando comenzamos a leer sobre el romancero del diecinueve, todas las referencias nos conducían a Domingo del Monte como un autor ineludible, aunque, paradójicamente, en la diversidad de textos de su autoría no hemos podido hallar alguno en el que se estudie este género de manera explícita. De ahí surge la necesidad de incorporar otras textualidades y otros autores para poder comprender el

\footnotetext{
${ }^{148}$ En el caso de José María Heredia, es condenado a muerte por el Capitán General de la Isla, Francisco Dionisio Vives a causa de la pronunciación de sus ideales independentistas, pero Heredia lograr escapar y se refugia primero, en Estados Unidos y, luego, obtiene asilo en México. En 1832, escribe una carta al entonces Capitán General de la isla, Miguel Tacón Rosique, en la que se retracta de sus ideales y éste le concede un permiso para regresar a la isla. Si bien Heredia no escribió romances su obra influyó en el joven Domingo del Monte y en los escritores de su generación. Por otro lado, "Plácido" es considerado un poeta popular, que escribía para "ganar el pan", es conocido, además por su arte de la improvisación. Plácido escribió algunos romances que se incluyen en la antología que elabora Samuel Feijoo (1977) entre ellos se destaca "Jicontencal" al que hemos hecho alusión en el capítulo IV. Un excelente trabajo sobre Plácido realiza Ambrosio Fornet, en el cual desarrolla la compleja y ambivalente posición del poeta en el campo de las letras cubanas (Fornet 2010). Hay que mencionar, además, que Plácido era mulato, hijo de madre española y padre cubano de raza negra y que fue fusilado en 1844 por su participación en la Conspiración de la Escalera.
} 
proceso de gestación del romancero patriótico, pues, sin duda, "hay una enorme actividad literaria en torno" a su figura. Esta profusión de escrituras que genera Del Monte en sus allegados nos ha conducido a realizar un recorte del corpus a los efectos de proponer un muestrario en el cual se puedan apreciar algunas figuraciones de la patria que - entendemos - condensan matrices simbólicas que replican el conflicto que supone la construcción de una identidad colectiva más o menos homogénea en una sociedad marcada por la heterogeneidad. Para llevar adelante la exploración de ese romancero, y ante la carencia de estudios específicos al respecto, reconstruimos las condiciones de emergencia, los circuitos de sociabilidad y de lectura, y los intereses ideológicos que subyacen en el grupo más íntimo de Domingo del Monte. Por otro lado, al recuperar algunos romances de una tercera generación de escritores (la de José Fornaris y Joaquín Lorenzo Luaces) fue posible hipotetizar respecto de la impronta delmontina y su aporte en la configuración de una tradición del romancero en Cuba. En este sentido, a su escueta labor de productor (los únicos romances que se conocen son los cuatro que publica en las Rimas americanas en 1833) hay que oponerle una permanente labor de tutor y guía de pares y discípulos a quienes insta a considerar el romance como un género apto para la transmisión de valores éticos, morales y patrióticos. Pero como dice Fina García Marruz, "su influjo nunca es directo". A las formas más habituales de influir en otros escritores ligadas a la práctica pedagógica, se agregan otras, tales como las funciones que ejerce en la Comisión Permanente de Literatura de la Sociedad Económica de Amigos del País, o los cargos que desempeña en distintas publicaciones en las cuales su voz se advierte en la elección de los temas a tratar. Por ejemplo, en el caso de la Revista Bimestre, se sabe que actuó como redactor de la sección "Variedades científicas y literarias". En el número 1 publicado en mayojunio de 1831 en el apartado "Obras nuevas" de esta sección, se registran dos publicaciones que guardan una estrecha relación con sus intereses literarios: una “colección de todas las coplas y cantares patrióticos que se cantan desde 1789 hasta el día (en francés) en París" (1831: 246) y una obra de "Boucher de Perthes, Romances cuentos y leyendas (en francés), París” (247). La mención de estas publicaciones que exponen la novedad, las "últimas noticias de impresión” pueden ser consideradas como formas sutiles propias del accionar de Del Monte para instalar temas, géneros y 
preocupaciones estéticas en el ámbito literario cubano. Por otro lado, como señala Víctor Goldgel (2010) estas secciones que aparecen en muchas de las publicaciones latinoamericanas del siglo diecinueve exponen un verdadero "caleidoscopio del saber", es decir, ponen de manifiesto una heterogeneidad que opera como principio constructivo y que es consecuencia de los múltiples y disímiles intereses de un sector letrado que, aunque pueda pertenecer a una misma clase, se desenvuelve en un sistema con marcadas desigualdades políticas. Desde nuestra tesitura, el caso de Domingo del Monte es paradigmático y su referencia nos sirve para describir y explicar las contradicciones que surgen en el ámbito de las letras decimonónicas y que se corresponden —en términos de Georgio Agamben — con su “contemporaneidad".

\section{Segunda parte}

\subsection{Domingo del Monte y la invención de la patria "moderna"}

Sosteníamos en el capítulo I que el punto de partida del proceso complejo - y no ajeno a contradicciones - de construcción de una identidad colectiva es la conciencia de los sujetos de pertenecer a un grupo. Es por ello que, si bien Antonio Benítez Rojo (1989) advierte en Cuba la conformación temprana — a comienzos del siglo diecisiete - de una sociedad y cultura criolla, ligada a la industria de la producción de cueros, localizada en el área oriental de la isla, habrá que esperar hasta el tercer decenio del siglo diecinueve, en el contexto de expansión capitalista de la industria azucarera, para advertir en los criollos blancos la emergencia de una conciencia de grupo que se torna explícita en un caudal discursivo que busca delimitar y establecer los parámetros de la cubanidad. De esta manera, los elementos que "mejor" expresan esta identidad colectiva resultan de procesos de selección llevados a cabo por los letrados de la Ilustración (y signados por sus disímiles intereses) en los cuales operan de manera simultánea dos estrategias contrastivas: una de inclusión y otra de exclusión que se desarrollan bajo una dinámica oscilante (Quijada 2003).

En este contexto debe situarse la producción ensayística y literaria de Domingo del Monte, quien produce, pero sobre todo alienta en sus coetáneos, la escritura de romances en los cuales se proyecten ciertos rasgos de la identidad patriótica. Sin 
embargo, esta conciencia patriótica y letrada no está exenta de contradicciones, pues como bien observa Mabel Moraña:

En el esfuerzo por convertir la historia en escritura, la empiria en interpretación, la realidad en utopía, la utopía en un sistema de representaciones didácticas y programáticas, la paradoja principal será la que atañe principalmente a la posicionalidad de los que fundan las narrativas protonacionales (1997: 70).

La cita que nos precede habilita la reflexión respecto del lugar paradójico de Domingo del Monte en la configuración de una primera matriz simbólica de la patria cubana. La posicionalidad profundamente compleja convierte a este hombre de letras en un signo de las paradojas de la Modernidad: primero, su labor consciente en distintos espacios pone de manifiesto la racionalización del saber y las permanentes tensiones entre lo instituido y lo novedoso; segundo, ostenta una actitud ambivalente hacia la metrópoli, por momentos se reconoce como español, en otros, como cubano. Su patria siempre es Cuba, pero la ambigüedad reside en si Cuba es española o es americana; tercero, desea que la Modernidad y "sus luces" lleguen a la isla, el ingenio promueve esa modernidad, entendida como progreso y adelanto, pero también considera que encarna la barbarie de la esclavitud. Frente a ésta mantiene una postura discursiva y otra fáctica, pues rechaza el sometimiento humano, pero es dueño de ingenios; cuarto, busca una forma literaria que exprese la peculiar identidad cubana, y en ese "espejamiento de las costumbres", contribuya a la formación del pueblo, aunque recurre a un género plenamente español para ese fin.

Las paradojas de la Modernidad que atraviesan a Domingo del Monte se inscriben en una serie de discursos tales como el Americanismo, el Criollismo, lo español, lo caribeño, etc. que otorgan espesor semántico a su producción y generan en un mismo sujeto distintos lugares de enunciación. Domingo del Monte asume la misión del "letrado patriota", en un contexto marcado por vertiginosos cambios sociales y políticos, y se constituye como vocero de los intereses de la patria (aunque en realidad sean los intereses de su clase). Ocupa varios espacios donde la letra tiene un lugar protagónico (academias, instituciones) y cuando esto no es posible, los crea (tertulias, publicaciones). Por esta razón, los gestos culturales que lleva adelante escenifican una tarea performativa, ética y pedagógica consciente, a partir de la cual busca fundar una 
retórica capaz de representar la cubanidad. Domingo del Monte no puede escapar a la "modernidad" de su propio tiempo y, en este sentido, la racionalización de un patrimonio económico y simbólico podría ser definida como la forma depurada de autoconciencia intelectual de una cultura. En el análisis que proponemos del romancero decimonónico señalamos de qué manera las metáforas de la tierra, la sangre y la memoria hacen perceptible este proceso de autoconciencia. Estos usos metafóricos operan como dispositivos generadores de sentido. En primer lugar, la memoria interviene respecto de los modos de interpretación del pasado y de la tradición, estableciendo márgenes, objetos y sujetos recuperables en relación a un sentido que se construye. En segundo lugar, la metáfora de la sangre permite revisar la valoración o subestimación del aspecto racial y la construcción de los lazos y vínculos culturales. Por último, podemos afirmar que la metáfora de la tierra y su construcción como "paisaje", "dominio" o "naturaleza" también proporciona elementos de identificación colectiva.

Al respecto, en los romances de Domingo del Monte advertimos una evocación nostálgica del pasado pre-industrial, la idealización de la campiña y del campesinado. En este caso, la memoria reconstruida opera como una forma de preservación y proyección de los intereses de los criollos reformistas interesados en hacer visibles los lazos raciales y culturales que "hermanan" a Cuba y a España. En este sentido, la elección del romance que hace Domingo del Monte como género más apto para la transmisión de un ideario patriótico criollo puede ser señalada como otra de las contradicciones, pues si bien pretende que el contenido de los romances exprese lo cubano (costumbres, prácticas, características de los sujetos) elige un género cuya tradición se halla profundamente arraigada en la Península Ibérica. Es decir, el romance en tanto género articula el imaginario de la patria criolla con la tradición cultural española. Si la alteridad supone una diferenciación y una delimitación de la propia identidad, la elección del romance como género que vehiculiza esta alteridad funciona como sutura de la ruptura de la necesaria diferencia que se impone. El romance, entre otros aspectos, enuncia la "hermandad" entre Cuba y España, pues como advierte Domingo del Monte, en la Península, este género ha servido más que ningún otro para expresar el sentimiento nacional. 
Por otro lado, en el mismo romancero se proyecta el deseo de borrar el elemento discordante, objeto de rechazo y temor: el negro. La metáfora de la sangre que hermana en la hispanidad a Cuba y a España, separa indefectiblemente a los blancos de los negros. Aunque que en otros textos Del Monte aluda a la retórica del mestizaje, pues avizora que será la única manera de blanquear paulatinamente a sociedad, en su romancero esta visión no aparece. En el romance "La patria", la "sangre esclava" no mancha la tierra, solo la riega el sudor de la frente del hombre libre. Es decir, su postura frente a la esclavitud exhibe que "la modernidad no es un bloque homogéneo, simétrico, armónico: está dividida contra sí misma”, es decir, no es "una trama cerrada, unívoca, transparente, universalmente inteligible de la simbolización” (2010: 45). Metaforizando este sentido, podríamos sostener que en Domingo Del Monte "su modernidad choca contra la Modernidad", pues es abolicionista pero pertenece a una familia que posee numerosos ingenios, considera que la esclavitud es signo de barbarie, pero al mismo tiempo concibe a la raza negra como inferior, rechaza desde su perspectiva religiosa, filantrópica y hasta romántica el sometimiento de los seres humanos y el estatus de mercancía, aunque avala la industrialización y modernización de los ingenios sostenidos por mano de obra esclava. Estas son algunas de sus contradicciones, por eso también podíamos señalarlo como un sujeto plenamente contemporáneo, entendiendo este término como lo concibe Giorgio Agamben (2008), para quien contemporáneo es aquel que tiene "la capacidad de percibir la oscuridad de su tiempo como algo que no deja de interpelarlo, aquel que no se deja enceguecer por las luces de su siglo”. Al respecto, Fina García Marruz observa: "No fue Del Monte ni el mejor ni el más sabio de los cubanos de su tiempo, pero sí el que recoge una suma mayor de inquietudes diversas, el más contradictorio y múltiple" (2008: 5).

Asimismo, en Del Monte, el rechazo al sujeto negro que se expresa en una contemplación exclusiva en términos de corporeidad o extranjería se refuerza en la elección del guajiro (criollo blanco) como el sujeto que articula, a través de la memoria, las figuraciones sobre la tierra y la sangre. Es por ello que el destierro aparece como la imagen más elaborada en el romancero delmontino. La tierra que se 
anhela es una tierra perdida - en términos materiales y en relación a la producción capitalista que instala la plantación_ — pues es arrasada por la maquinaria del ingenio.

La metáfora de la tierra sufre desplazamientos que obedecen a diferentes formas de relación entre el sujeto y la tierra: del locus amoenus y la naturaleza paradisíaca a la tierra industrialmente explotada. El carácter del vínculo entre sujeto/tierra también demarca procesos identitarios en transición. En este sentido, los romanceros de Domingo del Monte, Francisco Pobeda y José Jacinto Milanés presentan una similar configuración romántica de la naturaleza que expresa la interiorización del paisaje en el individuo: guajiro y tierra se complementan, sus rasgos se definen recíprocamente. Por otro lado, en sus textos, la heterogeneidad racial se incorpora a través de la representación del ingenio. Pobeda recurre a la imagen del grupo, la "negrada", para evitar la singularización y subjetivación del negro. En el caso de José Jacinto Milanés, la inclusión del tema es más radical, pues hay una crítica explícita al régimen de la esclavitud que se condensa en la imagen sádica del mayoral del ingenio y su ensañamiento contra los esclavos. En su romance, la esclavitud aparece como una práctica cruel que transforma a los hombres: el blanco que esclaviza se animaliza, el negro objeto se humaniza.

Sin embargo, en el romancero de poetas posteriores, como Miguel Teurbe Tolón y Joaquín Lorenzo Luaces emergen otras figuraciones sobre el ingenio que naturalizan la esclavitud y sus prácticas. Como resultado, el negro es considerado una mercancía y el criollo blanco, como el administrador de este bien. Esta mirada sobre la esclavitud guarda estrecha relación con los intereses anexionistas que profesaban sus autores y con un contexto más amplio de organización partidaria de las facciones liberales conocidas como reformismo, anexionismo y separatismo, que a partir de la segunda mitad de siglo establecen de manera formal sus principios doctrinales.

Pero las figuraciones sobre la patria contemplan distintos símbolos, tal es el caso del romancero de Ramón Vélez Herrera y de José Fornaris, donde aparece otro sujeto como articulador de los elementos que definen la identidad cubana: el indígena originario de la isla, el siboney. Aunque en este caso, la memoria selectiva recupera un sustrato de la identidad que ha sido eliminado totalmente, razón por la cual, la recreación de ese sujeto se basa en la idea de "huella", entendida como un registro 
profundo "esencial" que el pueblo originario ha dejado en la isla pese a su extinción. En esta reconstrucción simbólica opera una concepción mitológica que fragua una atemporalidad capaz de reactualizar de manera significativa la figura del siboney, a partir de dos elementos: resistencia (frente al enemigo que invade) y pertenencia (a la tierra).

Por otro lado, la construcción de la identidad patriótica se elabora en el romancero a partir de la recuperación de elementos culturales. La pelea de gallos aparece en varios romances como una práctica que detenta tradición y continuidad pues se aprecia su recreación en textos de distintas generaciones, desde Ramón Vélez Herrera a Miguel Teurbe Tolón y Joaquín Lorenzo Luaces. Por lo general, los romances cuyo tema central es la riña de gallos tienen un sesgo costumbrista, por esta razón, ofrecen un reservorio de imágenes sobre el escenario social: tipos sociales y étnicos, registros lingüísticos y hábitos que se organizan en torno a esta tradición popular.

Desde la perspectiva adoptada, analizamos las prácticas de sociabilidad en la que se inscribe la producción del romancero, pues consideramos que esto nos aportaría otros elementos para pensar el rol de los letrados como mediadores del repertorio simbólico. Domingo del Monte vuelve a ser la figura central a partir de la cual es posible hipotetizar sobre la dinámica de las relaciones letradas, pues su "propiedad irradiante" lo convierte en el centro de diversos espacios: academias, tertulias, publicaciones. De alguna manera, su impronta determina la proto-organización de un ámbito letrado que, en correspondencia con ciertas condiciones que impone la Modernidad, brega por una autonomía cultural que detente una identidad diferenciada de la metrópoli.

\subsection{Figuraciones sobre la patria: entre el olvido y la memoria}

Como consecuencia de la Revolución haitiana, durante la primera mitad del siglo diecinueve se instala en Cuba el imaginario de la peligrosidad que trae aparejada la heterogeneidad racial. Este discurso se intensifica hacia 1840, cuando los índices censales registran una entrada inusitada de esclavos que incrementa de manera fenomenal los índices de población negra. La heterogeneidad es considerada, entonces, 
como el problema central que amenaza la construcción de la nación civilizada. El discurso letrado de los criollos ilustrados instala un imaginario homogéneo que busca eliminar aquellos elementos discordantes. En este contexto, emerge la problemática de la lengua como valor simbólico de afiliación comunitaria e inscripción en lo histórico, pero también como recurso de integración. Sin embargo, la literatura, por su condición de opacidad, permite la incorporación de la temida otredad bajo formas de enunciación complejas y figuraciones que se superponen. Desde esta perspectiva, debimos considerar dos aspectos: el primero, es que la omisión puede ser advertida como una presencia; el segundo, que no existen omisiones causales sino causales. Nos preguntamos, entonces, cómo operan la memoria y el olvido en la configuración de las imágenes de la patria en el romancero decimonónico.

Partimos de la afirmación respecto de que "la nación, concebida como inseparable de las formas de identidad que van elaborándose históricamente en su interior, es también un proyecto en proceso, situado entre las virtudes y los rigores de la memoria" (Moraña 176).

$\mathrm{Si}$ bien algunos teóricos sostienen que es la memoria aquello que funda una nación — aquí pensamos en la noción de "tradición selectiva" de Raymond Williamsotros estudiosos ponen el acento en el olvido como componente central de todo proyecto nacional. Bajo esta última perspectiva, el silencio y el olvido organizan el sistema de inclusiones y exclusiones que delimitan la esfera identitaria.

Nos parece oportuno traer a colación el análisis que realizó Josefina Ludmer (1988) para pensar las apropiaciones letradas de los géneros populares, pues su mirada permite trazar algunas comparaciones con el romancero y el lugar de enunciación que asumen los letrados criollos: ¿qué sujetos son silenciados? ¿A quiénes se les otorga la voz? ¿Qué rasgos tiene esa voz concedida? Concluimos que los criollos le dan voz al guajiro pero se advierten distintos niveles. Pobeda es un poeta no culto, formado en la oralidad, ello explica el matiz popular que caracteriza su producción. Es, sin embargo, reconocido en el ámbito literario por pares como Domingo de Monte, quien se halla, por su formación erudita, en el otro extremo. En este caso, su saber le posibilita una apropiación consciente de los géneros literarios populares como medio para llegar al pueblo, aunque, en la ficcionalización de la oralidad del guajiro se apega al registro 
castizo. Un caso diferente es el de José Jacinto Milanés, pues reconoce la voz del Otro (negro), pero, al mismo tiempo, en la escritura marca con el uso de la itálica una distancia respecto de esa palabra. Otra incorporación de las voces populares es la que lleva a cabo Ramón Vélez Herrera porque ficcionaliza la oralidad latente en las plazas, en las fiestas populares e integra otros registros dando cuenta de una heterogeneidad lingüística pero, organizando ese espacio de interacción en la voz reguladora del yo narrador.

El mismo mecanismo que le otorga la voz al guajiro se la niega al negro esclavo. Como hemos mencionado, en el corpus estudiado, la esclavitud aparece como tema, no obstante, hay un borramiento de la subjetividad que conlleva a visibilizar solo los cuerpos. Esto no es casual, pues, de alguna manera, torna evidente el concepto de mercancía bajo el cual opera el sistema de la trata. Los cuerpos son posesiones y no necesitan voz. Pero, como en el caso de los romances "El negro alzado" o "Un rasgo de Juan Rivero", el esclavo puede burlar el sometimiento del amo: a falta de palabra, la fuga y el suicidio surgen como dos acciones de rebeldía.

El caso del poeta esclavo Juan Francisco Manzano y su Autobiografía de un esclavo (1839) parece ser excepcional pues su poética es testimonial, aunque su voz haya sido "domesticada" por las demandas de los letrados reformistas que necesitaban una confesión sobre la tortura y la brutalidad del régimen esclavista (Ramos 1996: 26). Sin embargo, un artículo, a nuestro criterio revelador, de Alberto Abreu Arcia (2014) nos puso al tanto de la existencia de otros escritores esclavos negros que irrumpen en el ámbito literario cubano entre 1850 y 1860. Su trabajo explora los imaginarios de la nación cubana que proponen un grupo de poetas esclavos negros y mulatos libres: Néstor Cepeda, Juan Antonio Frías, Mácsimo Hero de Neiba (Ambrosio Echemendía), Manuel Roblejo, Narciso Blanco (José del Carmen Díaz).

Abreu Arcia señala que estos autores se desenvuelven en un entorno provinciano, "en los bordes de los recintos amurallados de la ciudad letrada". Sus textos se dan a conocer a través de tertulias y periódicos como: El Alba (Villa Clara), El Correo (Trinidad), El Fanal (Puerto Príncipe), Camagüey, El Telégrafo (Cienfuegos); y en algunas publicaciones de la capital como El Siglo y La 
Fraternidad, esta última fundada por Juan Gualberto Gómez y estrechamente ligada al movimiento reivindicativo de negros y mulatos.

La presencia de estas publicaciones pone en evidencia el auge de la imprenta, un aspecto desarrollado en el capítulo II, pero, al mismo tiempo, revela un escenario que no hemos considerado: la importancia de la prensa en la difusión de textos producidos por esclavos y, en consecuencia, la articulación de los nuevos (y otros) signos e imágenes de la nación a partir de un sujeto nacional múltiple. Por otro lado, como supone Abreu Arcia, estas problemáticas relacionadas con la construcción de un campo de identidad racial no le fueron ajenas a la gran masa de lectores de la época.

Sin embargo, son varios los motivos que anota el autor como causantes del desconocimiento y omisión de estos autores. Entre otros señala: "la formación autodidacta de este grupo de poetas, sus cosmovisiones del mundo y sistemas comunicativos provenientes de la oralidad, el terror físico y psicológico que se deriva de su condición de esclavos, la carencia de un status legal, las restricciones sociales que le impiden acceder a la enseñanza, etc".

Más allá de que el texto no aporte muchos datos, nos interesa destacar la convivencia en el mismo periodo de imaginarios sobre la patria que entran en tensión pues detrás de esas representaciones subyacen sujetos heterogéneos que detentan distintos grados de subalternidad, hasta la esclavitud como negación de la subjetividad.

\section{Proyecciones}

Para concluir estas reflexiones finales, queremos - al menos - mencionar algunas proyecciones del romancero cubano advertidas hacia finales del siglo diecinueve y las primeras décadas del veinte.

Como señala el estudioso más importante de la décima en Cuba, Virgilio López Lemus (1997), en el siglo diecinueve, el uso del romance y de la décima está íntimamente ligado a los movimientos nativistas, criollistas e indigenistas, que surgen en las décadas del cuarenta y cincuenta. Asimismo, es un uso interrelacionado, que no implica la exclusión uno del otro, pues como bien notamos en el análisis del corpus, los romances incorporan la décima como manera de ficcionalizar la oralidad de los 
guajiros. Además, los mismos escritores que escriben romances son prolíficos autores de décimas. En el desarrollo de estos géneros en la isla, los críticos han mencionado algunos motivos que generaron un paulatino abandono del romance al mismo tiempo que la décima se imponía como forma privilegiada para expresar la cubanidad. En especial, porque esta forma - en principio no culta — estaba estrechamente vinculada con el cantar popular de los campesinos. El periodo de corte de nuestra investigación responde, precisamente, al hecho notorio de que fuera de ese marco temporal el romance aparece de manera muy esporádica en la producción letrada decimonónica; en cambio, la décima permanece vigente.

Podemos, no obstante, señalar algunos momentos en los cuales se advierte una recuperación del romance como género para expresar el sentimiento patrio. Hacia finales del siglo, José Martí cumple una función central (aunque inadvertida) en este proceso, pues cuando escribe en Nueva York el "Prólogo" a Los poetas de la guerra (1893), cuya edición estuvo a su cargo, indica la presencia de romances en esa obra y la forma en que estos textos circularon y se popularizaron durante la "Guerra de los Diez Años":

De copia en copia han venido guardándose, o en la memoria agradecida, los versos de la guerra (...) Tiene la guerra su poesía famosa, ya porque expresaba, en la forma ingenua y primeriza del mártir novel, los puros sentimientos que sacrificó alegre el de la patria, ya porque al filo de chiste le descabezaban al contrario una insolencia, ya porque dice hechos tales de sacrificio y ardor que ponen como una majestad involuntaria e inviolable sobre los que aquel aire respiraron (...) Periódicos hubo allí como El Mambí, El Cubano Libre, La Estrella Solitaria, y La Estrella de Jagua, de Hurtado, donde en el tipo mínimo de aquellas cajas andariegas vio luz mucha poesía generosa e histórica; y hasta un libro manuscrito llegó a componerse de lo mejor que se recitaba en una casa amiga, valiente tuvo la Revolución que no bien salvado en la ceja protectora, de la sorpresa de la sabana donde perdió los espejuelos, narraba,- envuelto aún en el humo y su cómica agonía, los combates, la amistad y el amor fueron puestos en rima o romances, inferiores siempre, por lo segundón y mestizo de la literatura en que se criaron, a las virtudes con que en ellos se copiaban insensiblemente los poetas. Su literatura no estaba en lo que escribían, sino en lo que hacían (...) y si hubiera dos notas salientes entre tantos versos de molde 
ajeno e inseguro, en que el espíritu nuevo y viril de los cubanos pedía en vano formas nuevas a una poética insignificante e hinchada, serían ellas la púdica ternura de los afectos del hogar, encendidos, como las estrellas en la noche en el silencioso campamento... (2).

La cita nos pone al tanto del uso del romance por parte de los poetas de la guerra, Martí califica a estas escrituras como "inferiores” en comparación con la gesta llevada a cabo por los poetas. El género romance "mestizo y segundón" se convierte en un "molde ajeno e inseguro" para expresar los ideales patrióticos, pero en tiempos de la guerra, no se habían desarrollado aún nuevas formas poéticas que se amalgamaran con ese deseo de independencia.

Por otro lado, Martí hace mención a las tertulias (práctica de sociabilidad que hemos abordado en el capítulo II) que se realizan en la residencia de Loreto Castillo de Duque de Estrada, en cuya casa "fue donde la poesía de la guerra tuvo más largo y abrigado asiento". Acudían a esas reuniones los poetas y recitaban sus décimas, sus sonetos, sus rimas y romances. Tal el caso de Ramón Roa (1844-1912), de quien Martí dice: "Y Roa, en los romances, felicísimo, siempre iba allí con uno nuevo, bien de burla amigable a los transidos amigos de Herminia, bien de agorero regocijado, pintando su entrada triunfal en el Camagüey, con más laudos que ropa y a las bellezas todas de su amistad, rodeándolo solícitas”.

Además, debemos recordar que en Martí el romance "asoma" en algunas de sus obras, como en el conocido verso IX "La niña de Guatemala” que integra los Versos sencillos (1891), en cuyo "Prólogo" Martí afirma: “creo en la necesidad de poner el sentimiento en formas llanas y sinceras". La "supuesta" sencillez de los versos martianos ha sido un tema abordado fructuosamente por la crítica, pero nos preguntamos si para José Martí el romance es una forma "llana y sencilla”. Resuenan en la respuesta las palabras de José Jacinto Milanés cuando demanda un tono sencillo para la poesía del pueblo. De hecho, son varios los críticos que advierten la huella de Milanés en la poesía martiana, y, como refiere Salvador Arias García (2014), Martí llama a Milanés “el poeta puro”, por su cubanía, su amor a la naturaleza, su dolor por los desposeídos.

El otro momento de recuperación del romancero debemos situarlo en la segunda década del siglo veinte. La influencia de los estudios sobre el folklore y el 
romancero que inicia Ramón Menéndez Pidal encuentra acogida entre algunos estudiosos como Carolina Poncet y de Cárdenas quien hemos referido, ha sido pionera en el estudio del romancero en Cuba (1914), incluso destacando la presencia del romancero decimonónico de tema patriótico. José María Chacón y Calvo (1892-1969) es la otra figura de renombre que recupera el romancero a partir de una labor consciente destinada a la institucionalización de los estudios folklóricos en Cuba. $\mathrm{Su}$ trabajo sobre el romancero, que data de 1922 es permanentemente citado. Junto a Fernando Ortiz impulsa la creación de instituciones, como la Sociedad del Folklore Cubano (1923) y la Institución Hispanocubana de Cultura (1926) y de publicaciones, tales como Archivos del Folklore Cubano (1924-1930), todas iniciativas culturales destinadas a recolectar, clasificar y difundir el material folklórico en la isla, teniendo en cuenta el sustrato que aportan a la identidad colectiva las tres vertientes: la indígena, la negra y la criolla (Ortiz García 2003). En este período, Fernando Ortiz se torna una figura insoslayable y su obra permite repensar el lugar del africano en la configuración de la identidad nacional. El valor del romance como forma literaria "pedagógica", tal como la conciben José Jacinto Milanés y Domingo Del Monte, es reactualizado en 1946 en la obra fundacional de Fernando Ortiz, Contrapunteo cubano del tabaco y del azúcar, cuando en el inicio afirma:

Un romance castizo a lo viejo, o unas vernáculas décimas guajiras o acurradas, que tuvieran por personajes contradictores el varonil tabaco y la femenina azúcar, podrían servir de buena enseñanza popular en la escuela y en canturrias, porque en el estudio de los fenómenos económicos y sus repercusiones sociales, pocas lecciones han de ser más elocuentes que las ofrecidas en nuestra tierra por el azúcar y el tabaco en sus notorias contraposiciones (1999: 2)

En el último capítulo de esta tesis señalábamos que el romancero decimonónico pone en escena un imaginario campesino en el cual se advierte la transición de la naturaleza paradisíaca a la tierra explotada por el cañaveral y explicábamos de qué manera esa figuración responde al impacto que la industria del ingenio produce en los campos y en los sujetos, modificando el paisaje social, cultural y económico. Una importante proyección del tema es la que lleva a cabo Agustín Acosta (1886-1979) quien publica en 1926 La zafra, poemario que transita como temas centrales las otras caras del 
ingenio, "ese coloso de hierro norteamericano" que genera violencia y miseria para el pueblo cubano. Según Cintio Vitier (2002) en este libro, "una atmósfera de desastre, de inminente peligro, algo vagamente amenazador, se cierne sobre los campo. Para el crítico cubano, el mayor acierto de Acosta es el haber sentido ese turbador aroma que impregna los campos durante la molienda, "ese obsesivo olor a caña de azúcar con su mezcla de delicia y angustia, sordamente cargado de anhelos, de amenaza, de resentimiento, de violencia contenida, esa paradoja de amargura y dulzura" (253). El poemario resulta fundacional en el contexto en que se inscribe ${ }^{149}$, pues une a la inquietud patria "la sugestión de una inminencia catastrófica vibrando en el aire" (254).

Sobre finales de la segunda década, y con la emergencia de la Revista de Avance (1927-1930), otro escenario se configura en Cuba pues, como sostiene Celina Manzoni (2001), la vanguardia articula un nuevo discurso sobre la nación y sobre la identidad que resignifica la tradición en un entramado cultural latinoamericano, en el cual confluyen una serie de relaciones (vanguardismo, nacionalismo, internacionalismo, etc.). En ese contexto de nuevas expresiones, irrumpe Nicolás Guillén con sus sones, con su poesía "negrista" " No obstante, como advierte Cintio Vitier (2002), en Sóngoro Cosongo (1931):

Guillén se acerca al romance de estirpe española para plantear ya los dos elementos originales de su sensibilidad: lo africano y lo español. Así salen "La canción del bongó", romance de negrismo un tanto demagógico y, el "Velorio de Papá Montero", con final de luna lorquiana, pero criollísimo en el son que lo centra categórico: ¡Ahora si que te rompieron, / Papá Montero! (300-301).

El uso del romance en este contexto heteróclito y complejo, de cambios, de rupturas, nos parece sugerente. No solo se producen revoluciones en el ámbito políticoinstitucional, a partir del repudio generalizado al gobierno de Gerardo Machado (1925-

\footnotetext{
${ }^{149}$ Recordemos que en 1920, frente a una suba de la zafra en el mercado, el monopolio norteamericano compra seis ingenios y tierras en las provincias orientales de la isla. Como consecuencia, se recrudecieron las condiciones de trabajo en el ingenio, los pequeños colonos y hacendados cayeron en ruina y se confiscaron tierras al mismo tiempo que fueron desalojados grupos de campesinos de sus propiedades. El libro de Ramiro Guerra y Sánchez (1880-1970) Azúcar y población en las Antillas publicado en 1927 es central para comprender el periodo republicano.

${ }^{150} \mathrm{Al}$ respecto, Celina Manzoni (2001) recupera y problematiza el debate respecto de la denominación en torno a la producción de escritores como Nicolás Guillén, Emilio Ballagas, Ramón Guirao, entre otros.
} 
1933), sino que la vanguardia irrumpe con la presencia de los intelectuales nucleados en torno a la Revista de Avance. Sin embargo, en Guillén, el romance vuelve a emerger como una "forma mestiza" que fragua una identidad en permanente tensión.

Si el uso del romance procura ser un gesto "suturador" de la diferencia, y la superficialidad de la forma es un mero mohín, podríamos pensar que el "fracaso" del gesto es un signo inequívoco de la irreductible heterogeneidad identitaria de Cuba. 


\section{Bibliografía citada}

\section{Fuentes primarias}

Bachiller y Morales, Antonio. Apuntes para la historia delas letras y de la instrucción Pública en la Isla de Cuba. La Habana: Imprenta de P. de Massana, 1859.

.Historia de las letras y de la Instrucción pública de la isla de Cuba, Tomo II. La Habana: Imprenta del tiempo, 1860.

Del Monte, Domingo. "Informes y exposiciones pedagógicos. Exposición de las tareas de la Comisión Permanente de Literatura de la Sociedad Económica Amigos del País". 1831. Escritos de Domingo del Monte. Antonio Fernández de Castro, José. ed. La Habana: Cultural, 1929. Versión completa University of Florida Digital Collections, University of Florida. Web, consultado el 5 de agosto 2008.

- "Primeras poesías líricas de España". Revista y Repertorio Bimestre de la Isla de Cuba. Número 1. Mayo y Junio 1831. Tomo I. Versión digitalizada University of Harvad. Web, consultado el 3 octubre de 2010.

. "El Montero de la sabana", "El desterrado del hato", "El Guajiro", "La Patria". Rimas americanas. Herrera Dávila, Ignacio, ed. La Habana: Imprenta de Palmer, 1833.

. Centón Epistolario. 1836-1840. Vol. 2. La Habana: Imagen Contemporánea, 2002.

. "El poeta". El Aguinaldo Habanero, La Habana. 1837. Escritos de Domingo del Monte. Antonio Fernández de Castro, José. ed. La Habana: Cultural, 1929. Versión completa University of Florida Digital Collections, University of Florida. Web, consultado el 5 de agosto 2008.

. "La poesía en el siglo XIX”. El Álbum, La Habana. 1838. Escritos de Domingo del Monte. Antonio Fernández de Castro, José. ed. La Habana: Cultural, 1929. Versión completa University of Florida Digital Collections, University of Florida. Web, consultado el 5 de agosto 2008.

De Palma, Ramón. Obras de Don Ramón de Palma con un prólogo de Anselmo Suárez y Romero. Vol. 1. La Habana: Imprenta del Gobierno, 1861. Versión digital completa University of Harvad. Web, consultado el 3 de abril de 2009.

Floresta Cubana, Periódico Quincenal de Ciencias, Literatura, Artes, Modas, Teatros, \&. Dedicado al bello sexo. La Habana: Imprenta y Encuadernación del Tiempo, 1856. Versión digital completa University of Harvard. Web, consultado el 10 de octubre de 2009. 
Fornaris, José. Cantos del Siboney. 1855. La Habana: Imprenta La Antilla, 1862. Versión digital completa University of Wisconsin, Madison. Web, consultado el 27 de agosto de 2009.

.Obras. Vol. 1. La Habana: Imprenta La Antilla, 1862. Versión digital completa University of Wisconsin, Madison. Web, consultado el 27 de agosto de 2009

Fornaris, José y Joaquín Lorenzo Luaces, eds. Cuba Poética, colección escogida de las composiciones en verso de los poetas cubanos, desde Zequeira hasta nuestros días. La Habana: Imprenta de la viuda de Barcina, 1861.

Gómez de Avellaneda, Gertrudis. Obra literaria de la Señora Doña Gertrudis Gómez de Avellaneda. Madrid: Imprenta y Estereotipia de M. Rivadeneyra, 1871.

Heredia, José María. Poesías. Nueva y completa edición incluyendo varias poesías inéditas. Dos tomos en un volumen. Nueva York: Roe Lockwood \& Son, 1853.

Laúd del desterrado. 1858. Texas: Arte Público Press, 1995.

López Prieto, Antonio. El parnaso cubano. Colección de poesías selectas de autores cubanos desde Zequeira a nuestros dias. Precedida de una introducción histórico-crítica sobre el desarrollo de la poesía en Cuba con biografías y notas críticas y literarias de sus respetados literatos. 1840. La Habana: Editor Miguel de Villa, 1881. Versión digital completa American Libraries. University of Wisconsin, Madison. Web, consultado el 27 de agosto de 2009.

Luaces, Joaquín Lorenzo. Poesías. La Habana: Imprenta del Tiempo, 1857.

Martí, José. "Nuestra América". 1891. Obras completas. Vol. 6. La Habana: Editorial Ciencias Sociales, 1991. 15-23.

- "Prólogo". Poetas de la guerra. Colección de versos a la Independencia de Cuba. Nueva York: Imprenta América, 1893. 1-11 Digitalizado University of Texas. Web, consultado el 11 de diciembre de 2009.

Medina, José Toribio. La Imprenta en La Habana 1707-1810. Santiago de Chile: Imprenta Elzeviriana, 1904. Versión digital completa American Libraries. Web, consultado el 15 de marzo de 2011.

Milanés, Federico. "Prologo". Obras de Don José Jacinto Milanés publicadas por su hermano. Nueva York: Juan F. Trow y Compañía, 1865.

Milanés, José Jacinto. Obras. La Habana: El Faro Industrial, 1846.

Manzano, Juan Francisco. Autobiografía de un esclavo. 1839. Madrid: Guadarrama, 1975. 
Pichardo y Tapia, Esteban. Diccionario provincial casi razonado de vozes cubanas. 1836. Versión digital de la tercera edición 1862. University of Toronto. Robarts Library. Web, consultado el 13 de agosto 2008.

Pobeda, Francisco. Poesías. Sagua La Grande: Imprenta de Don Antonio M. Alcover, 1863.

Revista y Repertorio Bimestre de la Isla de Cuba. Número 1. Mayo y Junio 1831. Tomo I. Versión digitalizada University of Harvad. Web, consultado el 3 de octubre de 2010.

Saco, José Antonio. "Carta de un patriota, o sea, clamor de los cubanos dirigidos a sus procuradores a cortes: Comercio de negros”. 1835. Obras. Volumen III. La Habana: Ediciones Imagen Contemporánea, 2001. 81-82.

. "La supresión del tráfico de esclavos africanos en la isla de Cuba, examinada con relación a su agricultura y a su seguridad". 1845. Obras. Volumen II. La Habana: Ediciones Imagen Contemporánea, 2001. 81-132.

. "Réplica de Don José Antonio Saco a la contestación del señor fiscal de la real hacienda de La Habana, Don Vicente Vázquez Queipo en el examen sobre el fomento de la población blanca, etc., en la isla de Cuba". 1847. Obras. Volumen III. La Habana: Ediciones Imagen Contemporánea, 2001. 200-221.

. "Epistolario". Obras. Volumen V. La Habana: Ediciones Imagen Contemporánea, 2001.

Teurbe Tolón, Miguel. Leyendas cubanas. Nueva York: Mesa \& Familton, 1856.

Vélez Herrera, Ramón. El Parnaso Cubano. Colección de Antonio López Prieto. La Habana: Imprenta de la Capitanía General, 1840.

Xicotencatl. 1826. Edición, introducción y notas de Gustavo Forero. México: Iberoamericana Vervuert, 2012.

Zambrana, José G. Roldán, R.M. de Mendive, F.L de Briñas. Cuatro laúdes. La Habana: La Cubana, 1853.

\section{Fuentes secundarias}

Abreu Arcia, Alberto. "Cuba: una patria y una nación imaginadas por los poetas esclavos del siglo XIX”. Afromodernidades. Blog. Web, consultado el 27 de abril de 2014.

Achugar, Hugo. "El parnaso es la nación o reflexiones a propósito de la lectura y el simulacro". Esplendores y miserias del siglo XIX: cultura y sociedad en América 
Latina, Beatriz González Stephan, coord. Caracas: Monte Ávila Editores, 1996. 53-72.

Acosta Peñaloza, Carmen E. Leer literatura. Ensayos sobre la lectura literaria en el siglo XIX. Bogotá: Palabra Magisterio, 2005.

Agamben, Giorgio. “¿Qué es lo contemporáneo?”. 2008. Salón Kritk. Web, consultado el 6 de abril de 2013.

Aguiar e Silva, Víctor. Teoría de la literatura. Madrid: Gredos, 1984.

Aguilera Manzano, José María. "Publicaciones periódicas e imprentas de La Habana entre 1824 y 1845 en los archivos cubanos y españoles". Anuario de Estudios Americanos Consejo Superior de Investigaciones Cientificas 64.1 (2007): 293328.

- "Las corrientes liberales habaneras a través de las publicaciones periódicas de la primera mitad del siglo XIX”. Cuban Studies 38.1 (2007): 125-153.

Aguirre, Mirta. "Poesía y cubanía”. Letras. Cultura en Cuba. Ana Cairo Ballester, ed. La Habana: Editorial Pueblo y Educación, 1997. 307-336.

. "El romancero". La lírica castellana hasta los Siglos de Oro. La Habana: Letras Cubanas, 1985. 469-534.

. "El romance en Cuba y en otros países de América Latina". Estudios literarios. La Habana: Letras cubanas, 1981. 25-34.

Alcibíades, Mirla. La heroica aventura de construir una república. Familia-nación en el ochocientos venezolano. Caracas: Monte Ávila-Celarg, 2004.

Altamirano, Carlos y Sarlo, B. "Del autor". Literatura/Sociedad. Buenos Aires: Hachette, 1983. 65-81.

Álvarez, Inmaculada. "El discurso sexual como valor de identidad nacional de lo cubano". Revista de Humanidades. Tecnológico de Monterrey 014 (2003): 13-35.

Amores Carredano, Juan Bosco. "Tradición y Modernidad en las lecciones de filosofía de Féliz Varela”. Iberoamericana 19 (2007): 185-199.

. "Reformas en la administración local en Cuba (1765-1854)". Actas del XV Congreso del Instituto Internacional de Historia del Derecho Indiano. Tomo I. Córdoba: Universidad de Córdoba, 2005. 63-79.

Anderson, Benedict. Comunidades imaginadas. Reflexiones sobre el origen y la difusión del nacionalismo. Buenos Aires: Fondo de Cultura Económica, 1993.

Andioc Torres, Shopie. "Presentación”. Centón epistolario de Domingo del Monte. Vol. 2. La Habana: Imagen Contemporánea, 2002. V-XXXIX.

Ardao, Arturo. Rodó, su americanismo. Montevideo: Biblioteca de Marcha, 1970. 
Arencibia Rodríguez, Lourdes. "Algunas reflexiones sobre la presencia en la literatura cubana del siglo XIX de Víctor Hugo a través de sus traducciones en homenaje a su bicentenario". Hieronymus 11 (2004): 2.

. "La traducción en las tertulias literarias del siglo XIX en Cuba". Hieronymus 45 (1996-1997): 27-46.

Arias García, Salvador. "Martí y José Jacinto Milanés, el poeta puro". La Jiribilla. Revista de cultura cubana. XII.690 (2014). Web, consultado el 20 de agosto de 2014.

Arrom, José Juan. "Criollo: definición y matices de un concepto". Certidumbre de América: estudios de literatura, folklore y cultura. 1959. La Habana: Letras Cubanas, 1980. 9-24.

Bajtín, Mijail. Estética de la creación verbal. Buenos Aires: Siglo XXI, 2001.

Barth, Fredrik ed. Los grupos étnicos y sus fronteras. La organización social de las diferencias culturales. Fondo de Cultura Económica: México, 1976.

Bello, Andrés. "Silva a la agricultura de la zona tórrida".1826. Obras completas de Don Andrés Bello. Vol. 3. Santiago de Chile: Imprenta de Pedro Ramírez, 1883. 66-76.

.Alocución a la poesía”. 1823. Obras completas de Don Andrés Bello. Vol. 3. Santiago de Chile: Imprenta de Pedro Ramírez, 1883. 38-61.

Benítez Rojo, Antonio. La isla que se repite: el Caribe y la perspectiva posmoderna. Hanover: Ediciones del Norte, 1989.

. "Azúcar/poder/literatura". Cuadernos Hispanoamericanos 451-2 (1988): 195-215.

Bernal Gómez, Beatriz. "Propuestas y proyectos constitucionales en la Cuba del siglo XIX”. Anuario de Historia del Derecho Español (Homenaje a Francisco Tomás y Valiente) LXVII (1997) I. Web, consultado el 25 de Octubre 2009.

. Dos siglos de pensamiento liberal cubano. 1994. Biblioteca Jurídica Virtual de la Universidad Nacional Autónoma de México. Web, consultado el 25 de octubre de 2009.

Betancourt, Patricia Lara, "La sala doméstica en Santafé de Bogotá silo XIX, el decorado: la sala barroca" Historia Crítica 20 (2001): 93-112.

Blanchet, Emilio. "La tertulia literaria de Delmonte". Revista de la facultad de Ciencias y Letras 14 (1912): 49-50.

Bourdieu, Pierre. La distinción. Criterio y bases sociales del gusto. Madrid: Taurus, 1988. 
Briceño Guerrero, José Manuel. El laberinto de los tres minotauros. Caracas: Monte Ávila, 2007.

Bruno, María Pía. "Imágenes de la patria en el romancero cubano (1830-1880)". Memorias del silencio. Literaturas en el Caribe y en Centroamérica. Graciela Salto, ed. Buenos Aires: Corregidor, 2010. 151-180.

. "Configuración de la patria y de las letras cubanas en el siglo XIX". Anclajes XIII (2009): 41-59.

Bruno, Paula. dir. Sociabilidades y vida cultural. Buenos Aires, 1860-1930. Buenos Aires: Universidad Nacional de Quilmes, 2014.

Bueno, Salvador. Costumbristas cubanos del siglo XIX, selección, prólogo, cronología y bibliografía Salvador Bueno. Caracas: Ayacucho, 1999. . La crítica literaria cubana del siglo XIX, La Habana: Letras Cubanas, 1979.

Camacho, Jorge. "Tu voz amorosa i triste": La política del lenguaje en la poesía de José Fornaris. Decimonónica 4.2 (2007): 1-15.

Carpentier, Alejo. Obras Completas. Ese músico que llevo dentro. 3. La música en Cuba. Volumen XII. México: Siglo XXI, 1987.

Castoriadis, Cornelius. La institución imaginaria de la sociedad. Barcelona: Tusquets. Vol. 1, 1983; Vol. 2, 1989.

Catalán, Diego. Arte poética del romancero oral. Parte 1. Los textos abiertos de creación colectiva. Madrid: Siglo XXI, Fundación Menéndez Pidal, 1997.

. "El romance, hoy". Conferencias de Diego Catalán. 1981. Fundación Juan March. Web, consultado el 23 de septiembre de 2010.

Catalán, Diego, Jesús A. Cid, Beatriz Mariscal de Rhett, Flor Salazar, Ana Valenciano y Sandra Robertson. CGR; Catálogo General del Romancero. 3 tomos. Madrid: Cátedra Seminario Menéndez Pidal, 1982-1984.

Chacón y Calvo, José María. Ensayos de literatura cubana. Madrid: Saturnino Calleja, 1922. Versión digital University of Michigan. Web, consultado el 10 de marzo de 2010 .

Chartier, Roger. "Lecturas y lectores 'populares' desde el Renacimiento hasta la época clásica". Historia de la lectura en el mundo occidental. Roger Chartier y Guglielmo Cavallo, dirs. Madrid: Taurus, 1998. 413- 434.

Chartier, Roger y Guglielmo Cavallo. Historia de la lectura en el mundo occidental. Madrid: Taurus, 1998.

Chiampi, Irlemar. "La expresión americana de José Lezama Lima: La dificultad y el diabolismo del caníbal”. Escritura X.19-20 (1985): 103-115. 
. "Teoría de la imagen y teoría de la lectura en Lezama Lima”. Nueva Revista de Filología Hispánica XXXV.2 (1987): 485-501.

Chicote, Gloria. Romancero. Buenos Aires: Colihue, 2012. . Romancero tradicional argentino. Queen Mary: University of London, 2002. . "El Romancero Panhispánico: reelaboración del tema del incesto en la tradición argentina". Hispanófila 122 (1998): 41-54.

Civantos, Christina. "Pechos de leche, oro y sangre: Las circulaciones del objeto y el sujeto en Cecilia Valdés". Revista Iberoamericana LXX.211 (2005): 505-519.

Coester, Alfred. "Hallazgo de un regalo desconocido de Domingo del Monte a José María Heredia". Hispania 22.4 (1939): 406-408.

Córdoba Rodríguez, Félix. "En torno a los diccionarios de americanismos". Philologica 74 (1999): 49-54.

Cornejo Polar, Antonio. Escribir en el aire. Ensayo sobre la heterogeneidad sociocultural en las literaturas andinas. Lima: Horizonte, 1994.

Crespo, Horacio. "El erudito coleccionista y los orígenes del americanismo". Historia de los intelectuales en América Latina. Volumen I. La ciudad letrada, de la conquista al modernismo. Carlos Altamirano, ed. y Jorge Myers, editor del volumen. Buenos Aires, Katz, 2008. 122-143.

Dávila, Luis Ricardo. "La modernidad fragmentada. A propósito de Andrés Bello", 2005. SABER-ULA. Universidad Nacional de los Andes. Web, consultado el 21 de septiembre de 2007.

De Lourenço Cileine. "Representación racial y ambigüedad en la narrativa fundacional”. Revista iberoamericana LXVIII.199 (2002): 317-330.

Díaz Pimienta, Alexis. Teoría de la improvisación. Oiartzun: Sendoa, 1998.

Díaz Quiñones, Arcadio. Sobre los principios. Los intelectuales caribeños y la tradición. Bernal: Universidad Nacional de Quilmes, 2006.

Díaz Roig, Mercedes. Romancero tradicional de América. México: El Colegio de México, 1990.

Duno Gottberg, Luis. Solventando las diferencias. La ideología del mestizaje en Cuba. Madrid: Iberoamericana, 2003.

Ebelot, Alfredo. "Riña de gallo". 1889. Tradición Gaucha. Web, consultado el 21 de abril de 2014.

Echeverría, Esteban. Elvira o la novia del Plata. 1832. Versión digital completa Cervantes Virtual. Web, consultado el 13 de marzo de 2014. 
Egido, Aurora. "La poética del silencio en el Siglo de Oro. Su pervivencia". Bulletin Hispanique 88.1-2 (1986): 93-120.

Ennis, Juan A y Stefan Pfänder. Lo criollo en cuestión. Filología e Historia. Buenos Aires: Katatay, 2013.

Feijoo, Samuel. Romances cubanos del siglo XIX. La Habana: Arte y Literatura, 1977.

Fernández, Claudia. "Clasicismos" .La teoría literaria hoy. Conceptos, enfoques, debates. Amícola, J. y de Diego, J L., dirs. La Plata: Ediciones Al margen, 2008. $35-43$.

Ferrer, Ada. "Noticias de Haití en Cuba” Revista de Indias LXIII.229 (2003): 675-694.

Fornet, Ambrosio. "El otro plácido, sus editores y sus críticos". Conferencia pronunciada en el Aula Magna de la Universidad de San Gerónimo como parte del ciclo conmemorativo del bicentenario del nacimiento de Plácido organizado por la Academia Cubana de la Lengua. 2010. Academia Cubana de la Lengua. Web, consultado el 20 de septiembre de 2012.

Foucault, Michael. Las palabras y las cosas. Buenos Aires: Siglo XXI, 1997.

Frenk, Margit. “Lectores y oidores en el Siglo de Oro”. Entre la voz y el silencio. La lectura en tiempos de Cervantes. México: Fondo de Cultura Económica, 2005.

Funes, Patricia. "América Latina: los nombres del Nuevo Mundo". Explora: las ciencias en el mundo contemporáneo. 2008. Explora.Educ.ar. Ministerio de Educación y Tecnología de la Nación. Web, consultado el 12 de agosto de 2011.

Gálvez, Víctor y Pastor S. Obligado. Tradiciones de Buenos Aires. Buenos Aires: Eudeba, 1977.

García Mora, Luis Miguel. "La fuerza de la palabra. El autonomismo en Cuba en el último tercio del siglo XIX”. Revista de Indias LXI.223 (2001): 715-748.

Geertz, Clifford. "Juego profundo: notas sobre la riña de gallos en Bali". La interpretación de las culturas. 1973. Barcelona: Gedisa, 1992. 339-372.

Gelz, Andreas. "Prensa y tertulia. Interferencias mediales en la España del siglo XVIII". Olivar 10.13 (2009): 165-200.

Glissant, Edouard. Poetics of relation. 1990. The University of Michigan Press: Ann Arbor, 1997.

Goldgel, Victor. Cuando lo nuevo conquistó américa. Prensa, moda y literatura en el siglo XIX. Buenos Aires: Siglo XXI, 2013.

- "Caleidoscopios del saber. El deseo de variedad en las letras Latinoamericanas del siglo XIX”. Estudios 18.36 (2010): 272-295. 
González Pérez, Aurelio. "El romancero en América y la tradición cubana". América sin nombre 2 (2000): 24-34.

González Ripoll, Dolores. “Ocio, lecturas y escrituras en la ilustración cubanas”. Revista de Indias LX.219 (2000): 331-343.

González- Ripoll Navarro, Ma. Dolores e Izaskun Álvarez Cuartero, eds. Francisco Arango y la invención de la cuba azucarera. Salamanca: Universidad de Salamanca, 2010.

Grüner, Eduardo. La oscuridad y las luces. Capitalismo, cultura y revolución. Buenos Aires: Edhasa, 2010.

.Un género culpable. La práctica del ensayo: entredichos, preferencias e intromisiones. Rosario: Homo Sapiens, 1996.

Guadarrama González, Pablo. Positivismo y antipositivismo en América Latina. La Habana: Ciencias Sociales, 2004.

Guerra, François-Xavier. "Epifanías de la nación”. Inventando la nación. Iberoamérica Siglo XIX. Antonio Annino y François-Xavier Guerra, coord. México: Fondo de Cultura Económica, 2003. 3-8.

.Modernidad e Independencias. Ensayos sobre las Revoluciones Hispánicas. México: Fondo de Cultura Económica, 1993.

Guerra, François-Xavier, Annick Lempérière et al. Los espacios públicos en Iberoamérica. México: Fondo de Cultura Económica, 1998.

Guerra, François-Xavier; Mónica Quijada, coords. Imaginar la nación. Münster Hamburg: Asociación de Historiadores Latinoamericanistas Europeos, 1994.

Gutiérrez de la Solana, Alberto. "La llama cubana de la poesía, desde el siglo XVII hasta Martí”. Anales de Literatura Hispanoamericana 17 (1988): 13-28.

Hamesse, Jacqueline. "El modelo escolástico de la lectura". Historia de la lectura en el mundo occidental. R. Chartier y G. Carvallo, eds. Madrid: Taurus, 2001. 157186.

Hauser, Arnold. Historia social de la literatura y el arte. Tomo 2. Madrid: Guadarrama, 1969.

Hobsbawn, Eric. La era de la revolución: Europa, 1889-1848. Barcelona: Crítica, 2005.

. Naciones y nacionalismos desde 1870: programa, mito y realidad. Barcelona: Crítica, 1998.

Ife, B.W. "La ficción a juicio". Lectura y ficción en el Siglo de Oro. Las razones de la picaresca. Madrid: Crítica, 1992. 11-44. 
Jitrik, Noé. Los grados de la escritura. Buenos Aires: Manantial, 2000.

Kabatek, Johannes. "Tradiciones discursivas y cambio lingüístico”. Lexis 29.2 (2005): 151-177.

Koselleck, Reinhart. Futuro pasado. Para una semántica de los tiempos históricos. Buenos Aires: Paidós, 1993.

Kutzinski, Vera M. Sugar's secrest. Race and the Erotics of Cuban Nationalism. Virginia: New World Studies, James Arnold Series Editor, 1993.

Leal Curiel, Carole. "Tertulia de dos ciudades: Modernismo tardío y formas de sociabilidad política en la provincia de Venezuela". Los espacios públicos en Iberoamérica. Ambigüedades y problemas. Siglos XVIII y XIX. Guerra y Lempérière, eds. México: Fondo de Cultura Económica, 1998. 168-180.

Leclercq, Cécile. El lagarto en busca de una identidad. Madrid: VervuertIberoamericana, 2004.

Lempérière, Annick. "Los hombres de letras hispanoamericanos y el proceso de secularización (1800-1850)". Historia de los intelectuales en América Latina. Volumen I. La ciudad letrada, de la conquista al modernismo. Carlos Altamirano, director y Jorge Myers, editor del volumen. Buenos Aires, Katz, 2008. 122-143.

- "La construcción de una visión euroamericana de la historia". Conceptualizar lo que se ve. François-Xavier Guerra, historiador. Homenaje. Erika Pani y Alicia Salmerón, eds. México: Instituto Mora, 2004. 397-418.

Lezama Lima, José et al. Antología de la poesía cubana, Siglo XIX. Tomo 2. Verbum Editorial, 2002.

Lezama Lima, José. La expresión americana. México: Fondo de Cultura Económica, 1993.

. "De la curiosidad barroca". Sucesivas y coordenadas. Buenos Aires: Espasa Calpe, 1993: 169-195.

Lienhard, Martín. Testimonios, cartas y manifiestos indígenas (desde la conquista hasta comienzos del siglo XX). Caracas: Ayacucho, 1992.

López, José R. "El cólera en Cuba: apuntes históricos" Revista Médica Electrónica 32.7 (2010) Matanzas. Cuba. Web, consultado el 7 de febrero de 2014.

López Lemus, Virgilio. La décima constante. Las tradiciones oral y escrita. La Habana: Fundación Fernando Ortiz, 1999.

. Doscientos años de poesía cubana. La Habana: Casa Editora Abril, 1999. . Décima e identidad. Siglos XVIII y XIX. La Habana: Academia, 1997. 
. La décima. Panorama breve de la décima en Cuba. La Habana: Academia, 1995.

Löwy, Michel y Robert Sayre. Rebelión y melancolía. El romanticismo como contracorriente de la modernidad. Buenos Aires: Nueva Visión, 2008.

Ludmer, Josefina. "Tretas del débil". La sartén por el mango; encuentro de escritoras latinoamericanas. Patricia González y Eliana Ortega, coord. Puerto Rico: Huracán, 1984. 17-54.

Mailhe, Alejandra "Avatares de la conceptualización de la cultura negra en la obra de Fernando Ortiz 1900-1940”. Orbis Tertuis XVI.17 (2011): 1-15.

Manguel, Alberto. Una historia de la lectura. Buenos Aires: Emecé, 2005.

Mantegazza, Pablo. "Riñas de gallo". 1858-1861. Tradición Gaucha. Web, consultado el 21 de abril 2014.

Manzoni, Celina. Un dilema cubano. Nacionalismo y vanguardia. La Habana: Fondo Editorial Casa de las Américas, 2001.

Mariscal, Beatriz, ed. Romancero General de Cuba. México: El Colegio de México, 1997.

Martínez-San Miguel, Yolanda. "Poéticas caribeñas de lo criollo: creole/criollo/creolité. Poéticas de lo criollo. La transformación del concepto criollo en las letras hispanoamericanas (siglos XVI-XIX). Juan M. Vitulli y D. Solodrow, comp. Buenos Aires: Corregidor, 2009. 403-441.

Mazín, Oscar. "Gente de saber en los virreinatos de Hispanoamérica (siglos XVI a XVIII)". Historia de los intelectuales en América Latina. Volumen I. La ciudad letrada, de la conquista al modernismo. Carlos Altamirano, dir. y Jorge Myers, ed. Buenos Aires, Katz, 2008. 53-78.

Mazzotti, José Antonio. "El criollismo y el debate (post)colonial en Hispanoamérica". Poéticas de lo criollo. La transformación del concepto criollo en las letras hispanomericanas (siglos XVI-XIX). Juan M. Vitulli y D. Solodrow, comp. Buenos Aires: Corregidor, 2009. 445-482.

Menéndez Pelayo, Marcelino. Historia de la Poesía Hispano-americana (México, América Central, Cuba, Santo Domingo, Puerto Rico, Venezuela, Colombia). 1911. Vol. 1. Santander: Consejo Superior de Investigaciones Científicas, 1948. 302-303.

Menéndez Pidal, Ramón. "La primitiva poesía lírica española”. Estudios literarios. Madrid: Espasa-Calpe, 1968. 157-212. . Romancero Hispánico. Teoría e Investigación. 2t. Madrid: Espasa-Calpe, 1953 

. Los romances de América y otros estudios. Buenos Aires: Espasa-Calpe, 1939.

Mignolo, Walter. "La colonialidad a lo largo y a lo ancho: el hemisferio occidental en el horizonte colonial de la modernidad". La colonialidad del saber: eurocentrismo y ciencias sociales. Perspectivas latinoamericanas. Lander, Edgardo, ed. Buenos Aires: Consejo Latinoamericano de Ciencias Sociales, 2000. 55-85.

. "Sobre alfabetización, territorialidad y colonización. La movilidad del sí mismo y del otro". Dispositio XXIV.1-2 (1989): 219-229.

. "La lengua, la letra, el territorio o la crisis de los estudios literarios coloniales". Dispositio 11.28-29 (1986): 137-160.

Mintz, Sidney Wilfred. Dulzura y poder: el lugar del azúcar en la historia moderna. México: Siglo XXI, 1996.

Mintz, Sidney W y Richard Price. El origen de la cultura africano- americana. Una perspectiva antropológica. México: Centro de Investigaciones y Estudios Superiores en Antropología Social, 2012.

Monguio, Luis. "Palabras e ideas: Patria y Nación en el Virreinato del Perú". Revista Iberoamericana 104-105 (1978): 451-470.

Montero, Susana. "La Moda o el sensor semanal del bello sexo. Una muestra temprana de la (mal) llamada prensa femenina cubana". La Jiribilla. Revista de Cultura Cubana 17 (2001). Web, consultado el 17 de agosto de 2010.

Moraña, Mabel. Políticas de la escritura en América Latina. De la Colonia a la Modernidad. Caracas: eXcultura, 1997.

."Barroco y conciencia criolla en Hispanoamérica". Revista de crítica literaria latinoamericana XIV.28 (1988): 229-251.

Moreno Fraginals, Manuel. El Ingenio. Tomo 1. La Habana: Editorial de Ciencias Sociales, 1978.

Myers, Jorge. "El letrado patriota: los hombres de letras hispanoamericanos en la encrucijada del colapso del imperio español en América". Historia de los intelectuales en América Latina. Vol. I. La ciudad letrada, de la conquista al modernismo. Carlos Altamirano, dir. y Jorge Myers, ed. Buenos Aires, Katz, 2008. 122-143.

- "Aquí nadie vive de las letras. Literatura e ideas desde el Salón Literario a la Organización Nacional". Historia crítica de la literatura argentina. La lucha de los lenguajes. Schvartzman Julio y Noé Jitrik, dirs. Buenos Aires: Emecé, 2003. 305-333. 
Nakladalova, Iveta. "Las metáforas de la lectura en el Siglo de Oro: la lectura como alimentación. Actas del Séptimo Congreso de la Asociación Internacional Siglo Oro. Madrid/ Frankfurt: Iberoamericana: 2005. 469-474.

Navarrete Linares, Federico "Los otros inventores de América: las tradiciones históricas amerindias". Nuevo Mundo Mundos Nuevos. Colloques. Revues.org. Web, consultado el 26 junio 2012.

O’Gorman, Edmundo. La invención de América. 1958. México: Fondo de Cultura Económica, 1984.

Orduna, German, ed. Selección de romances viejos de España y de américa. Selección estudio preliminar y notas Germán Orduna. Buenos Aires: Kapeluz, 1976.

Orta Ruiz, Jesús. Décima y folclor. La Habana: Unión, 1980.

Ortega, Josefina. "El empeño y el tiempo. Sociedad Económica de amigos del país". La Jiribilla. Revista de cultura cubana V.244 (2006). Web, consultado el 12 de febrero de 2013.

Ortega, Julio. "El discurso de la abundancia". El discurso de la abundancia. Caracas: Monte Ávila, 1990. 37-50.

Ortiz, Fernando. Los bailes y el teatro de los negros en el folclor de Cuba. 1951. La Habana: Letras Cubanas, 1985. .Contrapunteo cubano del tabaco y el azúcar. 1946. Madrid: CubaEspaña, 1999.

. "Los factores humanos de la cubanidad". Revista Bimestre Cubana XIV.2 (1940): 161-186.

. Los negros esclavos. 1916. La Habana: Editorial de Ciencias Sociales, 1995. . Los negros brujos. 1906. La Habana: Editorial de Ciencias Sociales, 1995.

Otero, Lisandro. "Delmonte y la cultura de la sacarocracia". Revista Iberoamericana LVI.152-153 (1990): 723-731.

Palti, Elías J. El tiempo de la política. Lenguaje e historia en el siglo XIX. Buenos Aires: Siglo XXI, 2007.

Parry, Adam. The Making of Homeric Verse. Oxford: Clarendon Press, 1971.

Pas, Hernán. "La crítica editada. Juan María Gutiérrez y la América poética”. Orbis Tertius XV.16 (2010): 1-12.

Pérez Fuentes, Pilar y Valverde, Lola. "La población de La Habana a mediados del siglo XIX: relaciones sexuales y matrimonio”. Historia Contemporánea 19 (1999): 155-179. 
Perilli, Carmen. Las colonias del Nuevo Mundo: Cultura y Sociedad. Tucumán: Universidad Nacional de Tucumán, 1995.

Piglia, Ricardo. "Sarmiento escritor”. Filología 31 (1998): 1-2.

Poema de Mio Cid. Colin Smith, ed. Madrid: Cátedra, 2005.

Poncet y de Cárdenas, Carolina. "El romance en Cuba". 1914. Investigaciones y apuntes literarios. Mirta Aguirre, ed. La Habana: Letras Cubanas, 1985. 9-192

Pratt, Mary Louise. Ojos imperiales: literatura de viajes y transculturación. Buenos Aires: Universidad Nacional de Quilmes, 1997.

Puig-Samper, Miguel Ángel y Naranjo Orovio, Consuelo. "Fernando Ortiz: herencias culturales y forja de la nacionalidad". Imágenes e imaginarios nacionales en el ultramar español. Consuelo Naranjo Orovio y Carlos Serrano, editores. Madrid: Consejo Superior de Investigaciones Científicas, 1999. 196-226.

Quijada, Mónica. "Sobre nación, pueblo, soberanía y otros ejes de la modernidad en el mundo hispánico" 2006: 19-51. Consejo Superior de Investigaciones Científicas.es Web, consultado el 14 de febrero 2008.

- “QQué nación? Dinámicas y dicotomías de la nación en el imaginario hispanoamericano del siglo XIX”. Inventando la nación. Iberoamérica Siglo XIX. Antonio Annino y François-Xavier Guerra, coord. México: Fondo de Cultura Económica, 2003. 287-315.

Rama, Ángel. La ciudad letrada. Hanover: Ediciones del Norte, 1984.

. “La modernización latinoamericana. 1870-1910”. Hispamérica XII.36 (1983): $3-19$.

Ramos, Julio. Paradojas de la letra. Caracas: Escultura, 1996.

. Desencuentros de la modernidad en América Latina. México: Fondo de Cultura Económica, 1989.

Rest, Jaime. “Clasicismo". Conceptos de literatura moderna. Buenos Aires: Centro Editor de América Latina, 1979. 25.

Rojas, Rafael. "El mar de los desterrados". La Habana Elegante. Segunda época 46 (2009). Web, consultado el 13 de agosto de 2014.

. Motivos de Anteo. Patria y nación en la historia intelectual de Cuba. Madrid: Colibrí, 2008.

- "Traductores de la libertad: el americanismo de los primeros republicanos" Historia de los intelectuales en América Latina. Volumen I. La ciudad letrada, de la conquista al modernismo. Carlos Altamirano, dir. y Jorge Myers, ed. Buenos Aires: Katz, 2008. 205-226. 
. "José María Heredia y la tradición republicana". Centro de Investigación y Docencia Económicas 48 (2007): 1-31.

Romano, Cira. "La Floresta Cubana y su continuadora, La Piragua: dos revistas del siboneyismo". La Jiribilla. Revista de cultura cubana XII.665 (2014). Web, consultado el 13 de agosto de 2014.

Romero, José Luis. Latinoamérica: las ciudades y las ideas. Buenos Aires: Siglo XXI, 2001.

.Buenos Aires. Historia de cuatro siglos. Buenos Aires: Altamira, 1983.

Rovira, Carlos "Siglo XII: ecos de la épica y la arcadia italiana en Cuba: Espejo de Paciencia de Silvestre de Balboa". América sin nombre 2 (2000): 35-42.

Rovira, José Carlos y Mataix, Remedios. "José Lezama Lima y la fundación imaginaria de la literatura colonial cubana". América sin nombre 2. (2000): 1623.

Sábato, Hilda, coord. "Nuevos espacios de formación y actuación intelectual: prensa, asociaciones, esfera pública (1850-1900)". Historia de los intelectuales en América Latina. Volumen I. La ciudad letrada, de la conquista al modernismo. Carlos Altamirano, dir. y Jorge Myers, ed. Buenos Aires: Katz, 2008. 387-411. .Ciudadanía política y formación de las naciones. Perspectivas históricas en América Latina. México: Fondo de Cultura Económica, 2003.

Salto, Graciela. "Nuevos tonos de antiguas voces cubanas: actualizaciones de la memoria oral". Ínsulas y poéticas. Figuraciones literarias en el Caribe. Buenos Aires: Biblos, 2012. 211-224.

Santamaría García, Antonio y Consuelo Naranjo Orovio. "La historia social de Cuba, 1868-1914. Aportaciones recientes y perspectivas". Nuevo Mundo Mundos Nuevos. Revues.org. web, consultado el 9 de febrero de 2008.

Sarduy, Severo. "Exiliado de sí mismo”. Obra completa. Madrid: Sudamericana, 1999. 41-43.

Schvartzman, Julio. Letras Gauchas. Buenos Aires. Eterna Cadencia, 2013.

Silva Beauregard, Paulette. Las tramas de los lectores. Estrategias de la modernización cultural en Venezuela (siglo XIX). Caracas: Fundación para la Cultura Urbana, 2007.

Silva, Renán. "Prácticas de lectura, ámbitos privados y formación de un espacio público moderno. Nueva Granada a finales del Antiguo Régimen". Los espacios públicos en Iberoamérica- Ambigüedades y problemas. Siglos XVIII-XIX. François-Xavier Guerra y Annick Lempérière, eds. México: Fondo de Cultura Económica, 1998. 80-102. 

. República liberal, intelectuales y cultura popular. Medellín: La Carreta, 2005.

Stewart. W y Glynn, James. "El surgimiento del mito nórdico". Introducción a la sociología. Buenos Aires: Paidós, 1977. 119-122.

Tejada Ripalda, Luis. "El americanismo. Consideraciones sobre el nacionalismo continental latinoamericano”. Investigaciones sociales VIII. 12 (2004): 167-200.

Trapero, Maximiano, coord. La décima: Su historia, su geografia, sus manifestaciones. Santa Cruz de Tenerife: Cámara Municipal de Évora / Centro de la Cultura Popular Canaria, 2001.

Trapero, Maximiano y Marta Esquenazi Pérez. Romancero tradicional y general de Cuba. Canarias: Consejería de Educación, Cultura y Deportes de España, 2002.

Uribe Ángel, Jorge Tomás. "La Universidad Colonial Neogranadina y la Ilustración". Revista Historia de la Educación Latinoamericana 7 (2005): 295-326.

Vera-León, Antonio. “Juan Francisco Manzano: el estilo bárbaro de la nación”. Hispamérica XX.60 (2001): 4-22.

Villaverde, Cirilo. Cecilia Valdés. La Habana: Letras Cubanas, 2002.

. “Amores y contratiempos de un guajiro". La Cartera Cubana. 2 (1839): 229.

Vitier, Cintio. Lo cubano en la poesía. La Habana: Letras Cubanas, 2002.

Williams, Raymond. El campo y la ciudad. 1973. Buenos Aires: Paidós, 2001. . Literatura y Marxismo. 1977. Barcelona: Península, 1997.

Zanetti, Susana. La dorada garra de la lectura. Lectoras y lectores de novela en América Latina. Buenos Aires: Beatriz Viterbo, 2002.

Zea, Leopoldo. "El positivismo y la emancipación cubana". El pensamiento latinoamericano. Barcelona: Ariel, 1976. 365-373.

Zumthor, Paul. Introducción a la poesía oral. Madrid: Taurus, 1991. 